Prepared in cooperation with the Oklahoma Water Resources Board

\title{
Hydrogeology and Model-Simulated Groundwater Availability in the Salt Fork Red River Aquifer, Southwestern Oklahoma, 1980-2015
}
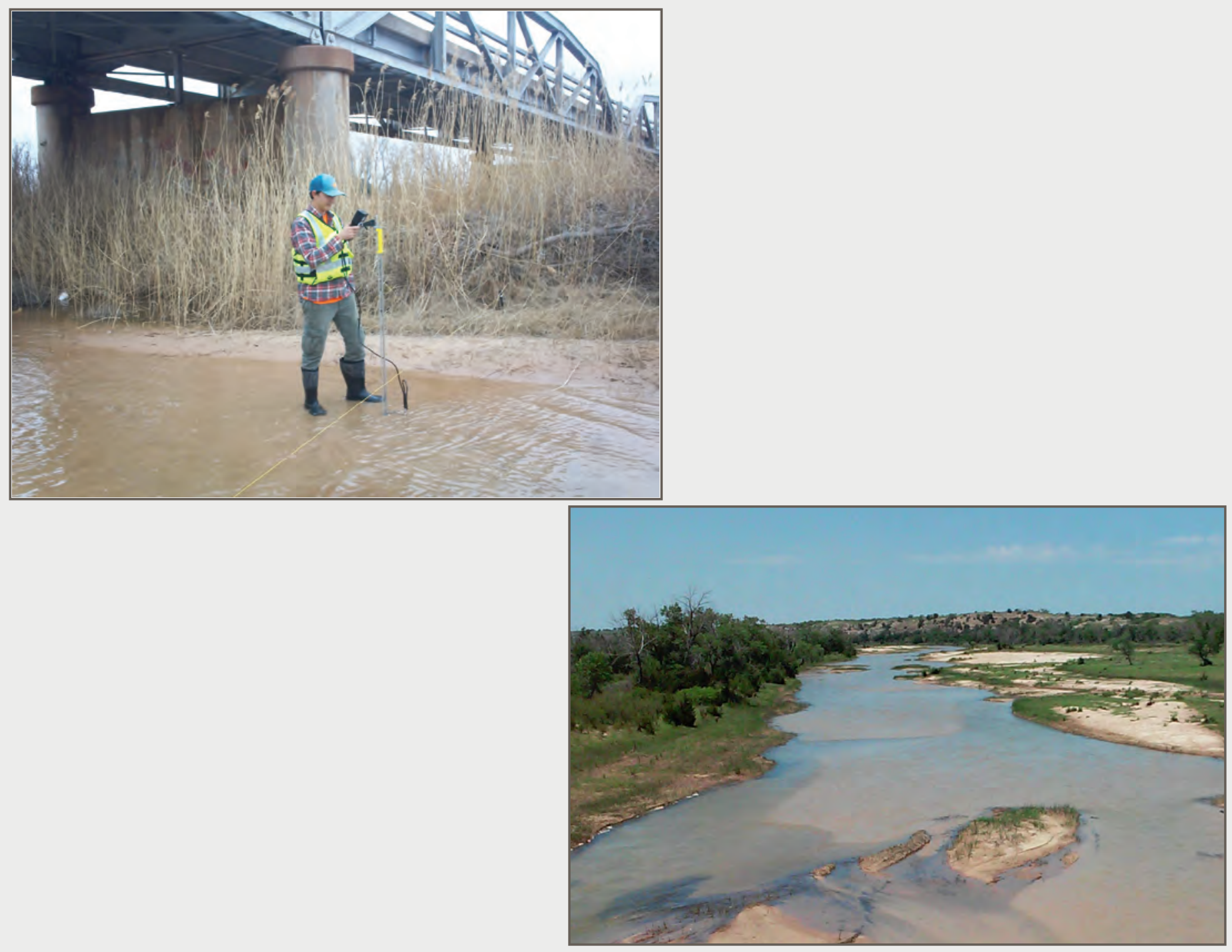

Scientific Investigations Report 2021-5003 


\section{Front cover}

Top, Hydrologic Technician Kyle VanVleet measures base flow in the Salt Fork Red River at Mangum, Oklahoma (USGS streamgage 07300500). Photograph by Marty Phillips, U.S. Geological Survey, March 9 , 2015.

Bottom, Salt Fork Red River near Reed, Oklahoma (USGS streamgage 07300472), looking upstream. Photograph by Carol Becker, U.S. Geological Survey, June 11, 2015.

\section{Back cover}

Top, Hydrologic Technician Marty Phillips measures base flow in the Salt Fork Red River north of Elmer, Oklahoma (USGS streamgage 07301103). Photograph by Stephen Bradford, U.S. Geological Survey, March 11, 2015.

Bottom, Salt Fork Red River aquifer core material collected from test hole Kh14 (USGS site 344751099513401; 04N-25W-29 BBB 1) in Harmon County, Oklahoma. Photograph by Carol Becker, U.S. Geological Survey, January 2, 2018. 


\section{Hydrogeology and Model-Simulated Groundwater Availability in the Salt Fork Red River Aquifer, Southwestern Oklahoma, 1980-2015}

By S. Jerrod Smith, John H. Ellis, Nicole C. Paizis, Carol J. Becker, Derrick L. Wagner, Jessica S. Correll, and R. Jacob Hernandez

Prepared in cooperation with the Oklahoma Water Resources Board

Scientific Investigations Report 2021-5003 


\section{U.S. Geological Survey, Reston, Virginia: 2021}

For more information on the USGS - the Federal source for science about the Earth, its natural and living resources, natural hazards, and the environment—visit https://www.usgs.gov or call 1-888-ASK-USGS.

For an overview of USGS information products, including maps, imagery, and publications, visit https://store.usgs.gov/.

Any use of trade, firm, or product names is for descriptive purposes only and does not imply endorsement by the U.S. Government.

Although this information product, for the most part, is in the public domain, it also may contain copyrighted materials as noted in the text. Permission to reproduce copyrighted items must be secured from the copyright owner.

Suggested citation:

Smith, S.J., Ellis, J.H., Paizis, N.C., Becker, C.J., Wagner, D.L., Correll, J.S., and Hernandez, R.J., 2021, Hydrogeology and model-simulated groundwater availability in the Salt Fork Red River aquifer, southwestern Oklahoma, 1980-2015: U.S. Geological Survey Scientific Investigations Report 2021-5003, 85 p., https://doi.org/10.3133/sir20215003.

ISSN 2328-0328 (online) 


\section{Acknowledgments}

The project documented in this report was conducted in cooperation with the Oklahoma Water Resources Board (OWRB) as part of the U.S. Geological Survey (USGS) Cooperative Water Program. The authors value the contributions of many OWRB and USGS staff that led to the successful completion of the project. The authors thank the OWRB for support on this project, especially Assistant Division Chief (Planning \& Management Division) Christopher Neel, who provided hydrogeologic data and helped with defining study objectives and deliverables, and Alex Schoppa, who compiled discharge data for the OWRB Hollis streamgage.

The authors express gratitude to USGS employees who performed data collection activities in the field. Marty Phillips, Martin Schneider, Stephen Bradford, Kyle VanVleet, and Tom Durst measured synoptic base flows during 2015-16. Shana Mashburn, Grant Graves, Kevin Smith, and Leland Fuhrig measured bedrock depths and horizontal hydraulic conductivities with the Geoprobe, collected synoptic water-table-altitude measurements in 2016, and installed and maintained continuous water-level recorder wells. In addition, Shana Mashburn and Waylon Marler facilitated data entry to the National Water Information System database, and Jeremy White provided support with respect to automated calibration of the numerical groundwaterflow model. The authors also thank USGS employees Andrew Long, lan Rogers, Chris Braun, Martha Watt, and Jeremy White, who performed detailed technical reviews on this report and the accompanying model archive data release. The authors acknowledge and appreciate the professionalism, experience, and dedication of these helpful and resourceful colleagues. 



\section{Contents}

Acknowledgments ……...................................................................................................................

Abstract

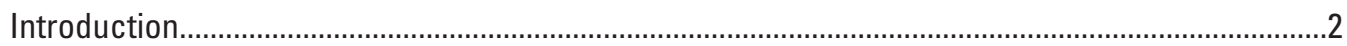

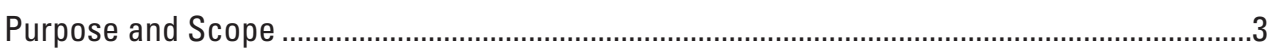

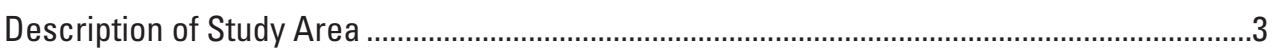

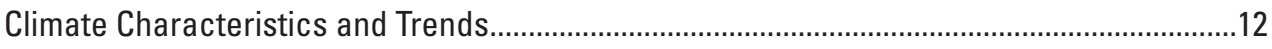

Groundwater-Use Characteristics and Trends ................................................................12

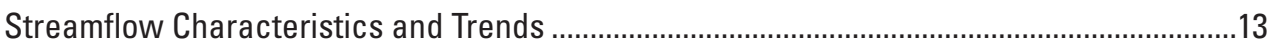

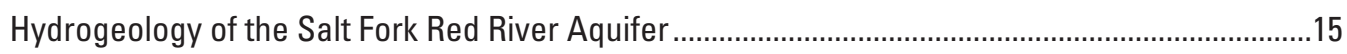

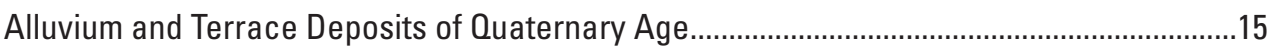

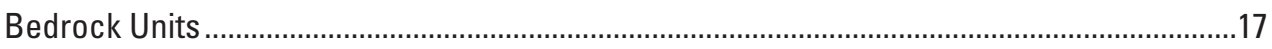

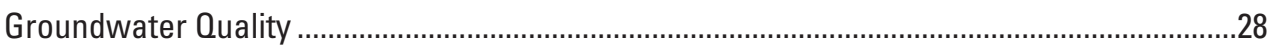

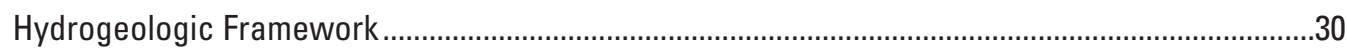

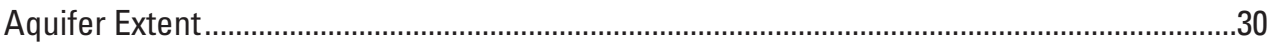

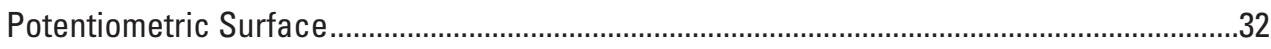

Textural and Hydraulic Properties of Aquifer Materials ......................................................34

Horizontal Hydraulic Conductivity Estimated in Test Holes and Cores..............................34

Horizontal Hydraulic Conductivity Estimated from Lithologic Logs.................................36

Vertical Anisotropy and Storage Properties .................................................................37

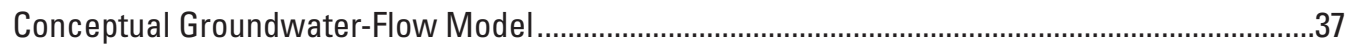

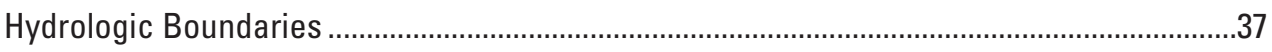

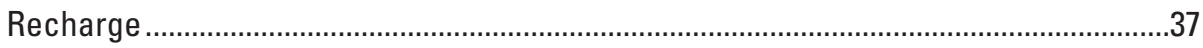

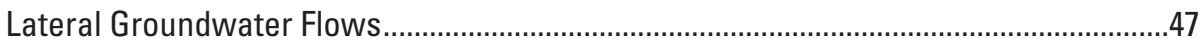

Streambed Seepage ..............................................................................................

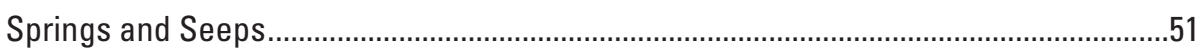

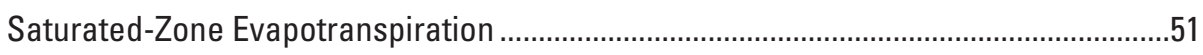

Well Withdrawals, Water-Level Response, and Storage Change..................................52

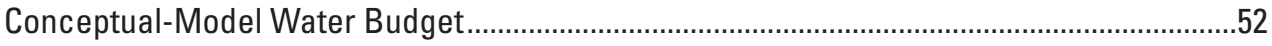

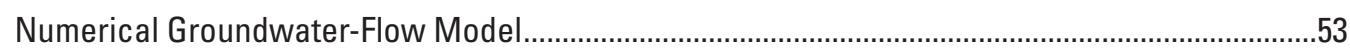

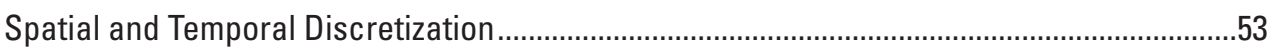

Simulation of Hydrologic Boundaries and Hydraulic Parameters..........................................53

Recharge and Distribution with the Soil-Water-Balance Code ......................................55

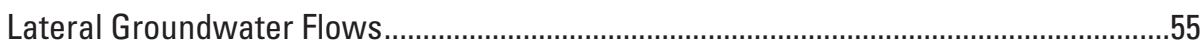

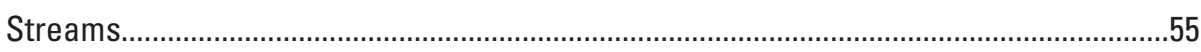

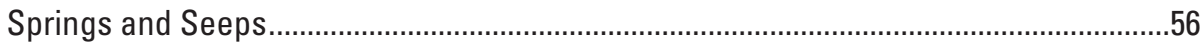

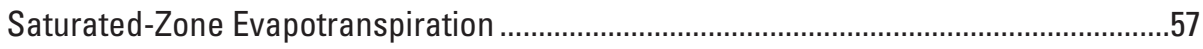

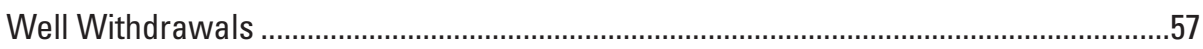

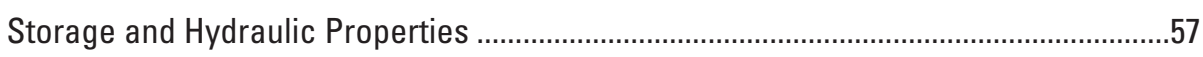

Solver Settings and Budget Percentage Discrepancies ................................................58

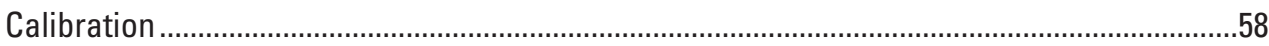

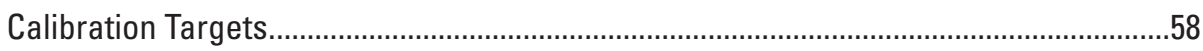

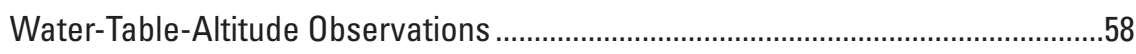

Base-Flow Observations ........................................................................................5 


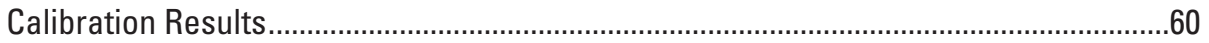

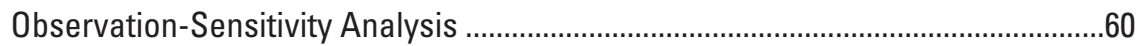

Calibrated Parameter Values....................................................................................61

Comparison of Simulated and Observed Calibration Targets....................................63

Calibrated Numerical-Model Water Budget ...............................................................63

Simulated Saturated Thickness and Available Water in Storage ............................67

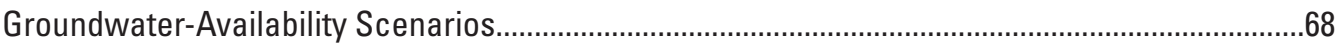

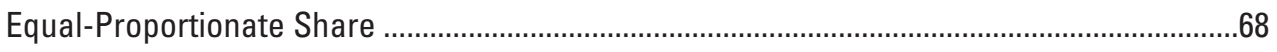

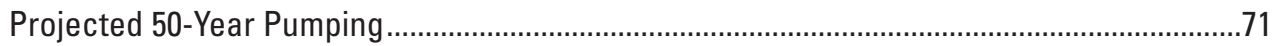

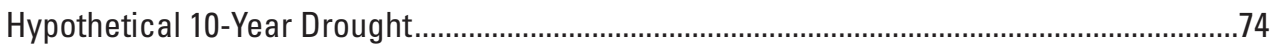

Model Limitations.............................................................................................................

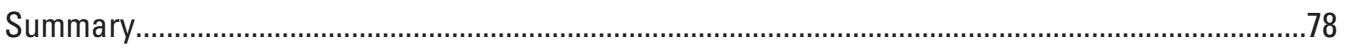

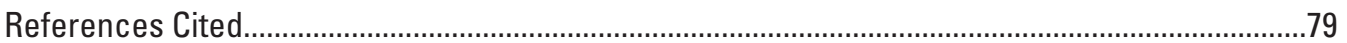

\section{Figures}

1. Map of the study area showing the extent of the Salt Fork Red River aquifer, southwestern Oklahoma.

2. Map showing the major geographic and surface-water features in and near the Salt Fork Red River watershed, southwestern Oklahoma and northwestern Texas.......10

3. Map and pie charts showing land and crop cover over the Salt Fork Red River aquifer, southwestern Oklahoma, 2010-17.

4. Graphs showing annual precipitation, annual temperature, and depth to water in selected wells, southwestern Oklahoma, 1895-2017.

5. Graphs showing mean monthly precipitation and mean monthly temperature, southwestern Oklahoma, 1895-2017 and 1980-2015

6. Map showing land areas and wells permitted for groundwater use from the Salt Fork Red River aquifer, southwestern Oklahoma, 2015

7. Graphs showing annual reported groundwater use from the Salt Fork Red River aquifer, southwestern Oklahoma, 1967-2015, for public supply or irrigation; delineated as permitted and reported; and upgradient or downgradient from Mangum gage

8. Graphs showing monthly streamflow, monthly base flow, and annual base-flow index values for U.S. Geological Survey streamgages 07300000 Salt Fork Red River near Wellington, Tex.; 07300500 Salt Fork Red River at Mangum, Okla.; and 07301110 Salt Fork Red River near Elmer, Okla., 1980-2017.

9. Map showing surficial geologic units and major structural features of the Salt Fork Red River aquifer study area, southwestern Oklahoma.

10. Stratigraphic chart describing surficial geologic and hydrogeologic units of the Salt Fork Red River aquifer study area, southwestern Oklahoma.

11. Hydrogeologic cross sections that include the Dodson terrace, the Mangum terrace, and the Martha terrace of the Salt Fork Red River aquifer, southwestern Oklahoma.

12. Map showing Stiff diagrams depicting major-ion concentrations measured in groundwater samples from wells completed in different geologic and hydrogeologic units in and near the Salt Fork Red River aquifer, southwestern Oklahoma 
13. Map showing the altitude of the base of the Salt Fork Red River aquifer in southwestern Oklahoma...

14. Map showing potentiometric-surface contours and general direction of groundwater flow in the Salt Fork Red River aquifer, 2016.

15. Graphs showing the distributions of estimated horizontal hydraulic conductivity observations in the Salt Fork Red River aquifer.

16. Bar graphs showing estimated mean annual inflows and outflows by water-budget category for the conceptual model and calibrated numerical model of the Salt Fork Red River aquifer, 1980-2015

17. Graphs showing daily and cumulative precipitation and depth to water in continuous water-level recorder wells completed in the Salt Fork Red River aquifer, January 2015-June 2017

18. Graphs showing annual precipitation with annual recharge estimated by using the Soil-Water-Balance code and mean monthly precipitation with mean monthly recharge and evapotranspiration estimated by using the Soil-Water-Balance code for the Salt Fork Red River aquifer, southwestern Oklahoma, 1980-2015.

19. Map showing mean annual recharge estimated by using the

Soil-Water-Balance code for the Salt Fork Red River aquifer, southwestern Oklahoma, 1980-2015.

20. Maps showing synoptic streamflow (base-flow) measurements and estimated streambed seepage in gaining and losing reaches of the Salt Fork Red River aquifer, southwestern Oklahoma, during February 16-18, 1988; March 9-12, 2015; and February 29-March 2, 2016

21. Map showing model domain, active modeled area, hydrologic boundaries, and parameter zones for the numerical groundwater-flow model of the Salt Fork Red River aquifer, southwestern Oklahoma

22. Graph showing monthly water demand by groundwater-use type for Oklahoma Comprehensive Water Plan water management planning basins 38 and 39, 2010 ........57

23. Graphs showing temporal distribution of U.S. Geological Survey and Oklahoma Water Resources Board water-table-altitude observations and streamflow observations used for the numerical groundwater-flow model of the Salt Fork Red River aquifer, southwestern Oklahoma

24. Graph showing observation group sensitivity by parameter group in the numerical groundwater-flow model of the Salt Fork Red River aquifer, 1980-2015........61

25. Map showing calibrated horizontal hydraulic conductivity for the numerical groundwater-flow model of the Salt Fork Red River aquifer, southwestern Oklahoma

26. Graphs showing relation between simulated and observed water-table altitudes; water-table-altitude residual distribution; and observed and simulated water-table altitudes for Oklahoma Water Resources Board well 9442 for the numerical groundwater-flow model of the Salt Fork Red River aquifer, southwestern Oklahoma, 1980-2015

27. Map showing mean water-table-altitude residuals at individual wells used to calibrate the numerical groundwater-flow model of the Salt Fork Red River aquifer, southwestern Oklahoma, 1980-2015

28. Graphs showing observed base flow and simulated base flow at U.S. Geological Survey streamgages 07300500 Salt Fork Red River at Mangum, Okla., and 07301110 Salt Fork Red River near Elmer, Okla., for the numerical groundwater-flow model of the Salt Fork Red River aquifer, southwestern Oklahoma, 1980-2015. 
29. Graph showing annual inflows, outflows, and cumulative net change in groundwater storage for the numerical groundwater-flow model of the Salt Fork Red River aquifer, southwestern Oklahoma ..

30. Map showing simulated saturated thickness at the end of the period 19802015 for the calibrated numerical model of the Salt Fork Red River aquifer, southwestern Oklahoma.

31. Graphs showing changes in simulated base flow and simulated groundwater storage during 20,40 , and 50 years of continuous equal-proportionate-share groundwater pumping in the Salt Fork Red River aquifer, southwestern Oklahoma ......72

32. Map showing simulated saturated thickness and base flow after 20 years of continuous equal-proportionate-share groundwater pumping in the Salt Fork Red River aquifer, southwestern Oklahoma

33. Graphs showing simulated mean annual base flow at U.S. Geological Survey streamgages 07300500 Salt Fork Red River at Mangum, 0kla., and 07301110 Salt Fork Red River near Elmer, Okla., through 50 years of groundwater pumping at selected rates in the Salt Fork Red River aquifer, southwestern Oklahoma

34. Graph showing changes in simulated groundwater storage resulting from a hypothetical 10-year drought (1983-92) for the Salt Fork Red River aquifer, southwestern Oklahoma.

35. Graphs showing changes in simulated base flow at U.S. Geological Survey streamgages 07300500 Salt Fork Red River at Mangum, Okla., and 07301110 Salt Fork Red River near Elmer, Okla., resulting from a hypothetical 10-year drought (1983-92) for the Salt Fork Red River aquifer, southwestern Oklahoma.

\section{Tables}

1. Selected data-collection stations in and near the Salt Fork Red River aquifer study area, southwestern Oklahoma.

2. Mean annual precipitation and mean annual temperature for selected periods, southwestern Oklahoma, 1895-2017

3. Annual reported groundwater use from the Salt Fork Red River aquifer, 1967-2015......16

4. Annual mean streamflow, base flow, and base-flow index values for selected U.S. Geological Survey streamgages in and near the Salt Fork Red River aquifer study area, 1980-2017

5. Hydraulic properties calculated from Geoprobe hydraulic profiling tool test holes and cored test holes in the Salt Fork Red River aquifer .35

6. Conceptual-model water budget for the Salt Fork Red River aquifer, 1980-2015............38

7. Summary of recharge estimates using the water-table fluctuation method for the Salt Fork Red River aquifer, 1986-88 and 2015-17.

8. Calibration parameters for the numerical groundwater-flow model of the Salt Fork Red River aquifer, 1980-2015.

9. Components of the objective function for the automated calibration of the numerical groundwater-flow model of the Salt Fork Red River aquifer, 1980-2015 ........59

10. Calibrated numerical-model water budget for the Salt Fork Red River aquifer, 1980-2015

11. Hydraulic properties, storage properties, and available water in storage at the end of the numerical-model period for the Salt Fork Red River aquifer, 1980-2015........70

12. Equal-proportionate-share pumping rates for the Salt Fork Red River aquifer, southwestern Oklahoma. 
13. Changes in groundwater storage after 50 years of groundwater pumping at selected rates at simulated wells for the Salt Fork Red River aquifer,

southwestern Oklahoma.....

14. Change in groundwater storage after a hypothetical 10-year drought for the Salt Fork Red River aquifer, 1983-92.

\section{Conversion Factors}

U.S. customary units to International System of Units

\begin{tabular}{|c|c|c|}
\hline Multiply & By & To obtain \\
\hline \multicolumn{3}{|c|}{ Length } \\
\hline inch (in.) & 2.54 & centimeter $(\mathrm{cm})$ \\
\hline inch (in.) & 25.4 & millimeter $(\mathrm{mm})$ \\
\hline foot $(\mathrm{ft})$ & 0.3048 & meter $(\mathrm{m})$ \\
\hline mile (mi) & 1.609 & kilometer $(\mathrm{km})$ \\
\hline \multicolumn{3}{|c|}{ Area } \\
\hline acre & 4,047 & square meter $\left(\mathrm{m}^{2}\right)$ \\
\hline acre & 0.4047 & hectare (ha) \\
\hline acre & 0.4047 & square hectometer $\left(\mathrm{hm}^{2}\right)$ \\
\hline acre & 0.004047 & square kilometer $\left(\mathrm{km}^{2}\right)$ \\
\hline square mile $\left(\mathrm{mi}^{2}\right)$ & 259.0 & hectare (ha) \\
\hline square mile $\left(\mathrm{mi}^{2}\right)$ & 2.590 & square kilometer $\left(\mathrm{km}^{2}\right)$ \\
\hline \multicolumn{3}{|c|}{ Volume } \\
\hline acre-foot (acre-ft) & 1,233 & cubic meter $\left(\mathrm{m}^{3}\right)$ \\
\hline acre-foot (acre-ft) & 0.001233 & cubic hectometer $\left(\mathrm{hm}^{3}\right)$ \\
\hline \multicolumn{3}{|c|}{ Flow rate } \\
\hline acre-foot per year (acre-ft/yr) & 1,233 & cubic meter per year $\left(\mathrm{m}^{3} / \mathrm{yr}\right)$ \\
\hline acre-foot per year (acre-ft/yr) & 0.001233 & cubic hectometer per year $\left(\mathrm{hm}^{3} / \mathrm{yr}\right)$ \\
\hline foot per second ( $\mathrm{ft} / \mathrm{s})$ & 0.3048 & meter per second $(\mathrm{m} / \mathrm{s})$ \\
\hline foot per day (ft/d) & 0.3048 & meter per day $(\mathrm{m} / \mathrm{d})$ \\
\hline foot per year (ft/yr) & 0.3048 & meter per year $(\mathrm{m} / \mathrm{yr})$ \\
\hline cubic foot per second $(\mathrm{ft} 3 / \mathrm{s})$ & 0.02832 & cubic meter per second $\left(\mathrm{m}^{3} / \mathrm{s}\right)$ \\
\hline cubic foot per day (ft3/d) & 0.02832 & cubic meter per day $\left(\mathrm{m}^{3} 3 \mathrm{~d}\right)$ \\
\hline gallon per minute (gal/min) & 0.06309 & liter per second $(\mathrm{L} / \mathrm{s})$ \\
\hline inch per year (in/yr) & 25.4 & millimeter per year (mm/yr) \\
\hline mile per hour $(\mathrm{mi} / \mathrm{h})$ & 1.609 & kilometer per hour $(\mathrm{km} / \mathrm{h})$ \\
\hline \multicolumn{3}{|c|}{ Hydraulic conductivity } \\
\hline foot per day (ft/d) & 0.3048 & meter per day $(\mathrm{m} / \mathrm{d})$ \\
\hline \multicolumn{3}{|c|}{ Hydraulic gradient } \\
\hline foot per mile (ft/mi) & 0.1894 & meter per kilometer $(\mathrm{m} / \mathrm{km})$ \\
\hline \multicolumn{3}{|c|}{ Transmissivity } \\
\hline foot squared per day ( $\left.\mathrm{ft}^{2} / \mathrm{d}\right)$ & 0.09290 & meter squared per day $\left(\mathrm{m}^{2} / \mathrm{d}\right)$ \\
\hline
\end{tabular}


International System of Units to U.S. customary units

\begin{tabular}{|c|c|c|}
\hline Multiply & By & To obtain \\
\hline \multicolumn{3}{|c|}{ Length } \\
\hline centimeter $(\mathrm{cm})$ & 0.3937 & inch (in.) \\
\hline millimeter (mm) & 0.03937 & inch (in.) \\
\hline meter $(\mathrm{m})$ & 3.281 & foot $(\mathrm{ft})$ \\
\hline meter $(\mathrm{m})$ & 1.094 & yard (yd) \\
\hline \multicolumn{3}{|c|}{ Flow rate } \\
\hline meter per second $(\mathrm{m} / \mathrm{s})$ & 3.281 & foot per second $(\mathrm{ft} / \mathrm{s})$ \\
\hline
\end{tabular}

Temperature in degrees Fahrenheit $\left({ }^{\circ} \mathrm{F}\right)$ may be converted to degrees Celsius $\left({ }^{\circ} \mathrm{C}\right)$ as follows:

${ }^{\circ} \mathrm{C}=\left({ }^{\circ} \mathrm{F}-32\right) / 1.8$.

\section{Datum}

Vertical coordinate information is referenced to the North American Vertical Datum of 1988 (NAVD 88).

Horizontal coordinate information is referenced to the North American Datum of 1983 (NAD 83).

Altitude, as used in this report, refers to distance above the vertical datum.

\section{Supplemental Information}

Transmissivity: The standard unit for transmissivity is cubic foot per day per square foot times foot of aquifer thickness [(ft3/d)/ft2] ft. In this report, the mathematically reduced form, foot squared per day $(\mathrm{ft} 2 / \mathrm{d})$, is used for convenience.

Concentrations of chemical constituents in water are given in either milligrams per liter (mg/L) or milliequivalents per liter. 


\section{Abbreviations}

$\begin{array}{ll}\text { BITT } & \text { Bitter Creek inflow for Streamflow-Routing package } \\ \text { BFI } & \text { base-flow index } \\ \text { CMIP5 } & \text { Coupled Model Intercomparison Project } 5 \\ \text { DEM } & \text { digital elevation model } \\ \text { EPS } & \text { equal-proportionate share } \\ \text { GHB } & \text { general-head boundary } \\ \text { HOB } & \text { Head Observation package } \\ \text { HPT } & \text { hydraulic profiling tool } \\ \text { HVSR } & \text { horizontal to vertical spectral ratios } \\ \text { IDW } & \text { inverse distance weighted } \\ \text { MAY } & \text { maximum annual yield } \\ \text { NWI } & \text { National Wetlands Inventory } \\ \text { OWRB } & \text { Oklahoma Water Resources Board } \\ \text { RMSE } & \text { root-mean-square error } \\ \text { SFR2 } & \text { Streamflow-Routing package, version 2 } \\ \text { SFRR } & \text { Salt Fork Red River inflow for Streamflow-Routing package } \\ \text { SWB } & \text { Soil-Water-Balance code } \\ \text { TURK } & \text { Turkey Creek inflow for Streamflow-Routing package } \\ \text { USGS } & \text { U.S. Geological Survey } \\ \text { WTF } & \text { water-table fluctuation }\end{array}$





\title{
Hydrogeology and Model-Simulated Groundwater Availability in the Salt Fork Red River Aquifer, Southwestern Oklahoma, 1980-2015
}

\author{
By S. Jerrod Smith,1 John H. Ellis, ${ }^{1}$ Nicole C. Paizis, ${ }^{1}$ Carol J. Becker,1 Derrick L. Wagner,2 Jessica S. Correll, ${ }^{2}$ \\ and R. Jacob Hernandez²
}

\section{Abstract}

The 1973 Oklahoma Water Law (82 OK Stat $\S$ 82-1020.5) requires that the Oklahoma Water Resources Board (OWRB) conduct hydrologic investigations of the State's groundwater basins to support a determination of the maximum annual yield for each groundwater basin (hereinafter referred to as an "aquifer"). The maximum annual yield allocated per acre of land is known as the equal-proportionateshare (EPS) pumping rate. At present (2021), the OWRB has not yet established a maximum annual yield and EPS pumping rate for the Salt Fork Red River aquifer. To provide updated information to the OWRB that could support evaluation and determination of an appropriate maximum annual yield, the U.S. Geological Survey (USGS), in cooperation with the OWRB, conducted a hydrologic investigation and evaluated the effects of potential groundwater withdrawals on groundwater availability in the Salt Fork Red River aquifer.

The Salt Fork Red River aquifer in Greer, Harmon, and Jackson Counties of southwestern Oklahoma is composed of about 274.5 square miles of alluvium and terrace deposits associated with the Salt Fork Red River. The mean annual recharge rate to the Salt Fork Red River aquifer for the period 1980-2015 was estimated to be about 2.94 inches per year, or 10.0 percent of the mean annual precipitation for the same period (29.4 inches per year). This 1980-2015 mean annual recharge rate is equivalent to a mean annual recharge rate of about 38,000 acre-feet per year (acre-ft/yr) for the Salt Fork Red River aquifer excluding about 19,764 acres comprising the Mulberry Creek and Horse Creek terraces. The mean annual recharge rates upgradient and downgradient from USGS streamgage 07300500 Salt Fork Red River at Mangum, Okla. (hereinafter referred to as the "Mangum gage"), apportioned by aquifer area (41.5 and 58.5 percent, respectively), were about 16,000 and 22,000 acre-ft/yr, respectively. Mean annual groundwater use for the study period (1980-2015) was $3,532.7$ acre-ft/yr; about 77 percent of that groundwater use

\footnotetext{
1U.S. Geological Survey.
}

2Oklahoma Water Resources Board. was for irrigation, and about 23 percent was for public supply. Most groundwater use for irrigation was associated with wells in the Martha terrace.

A hydrogeologic framework was developed for the Salt Fork Red River aquifer and included a definition of the aquifer extent and potentiometric surface, as well as a description of the textural and hydraulic properties of aquifer materials. The hydrogeologic framework was used in the construction of the numerical groundwater-flow model of the Salt Fork Red River aquifer described in this report. A conceptual model for the Salt Fork Red River aquifer that reasonably represents the groundwater-flow system was developed to constrain the construction and calibration of the numerical model. The conceptual-model water budget estimated mean annual inflows to, and outflows from, the Salt Fork Red River aquifer for the period 1980-2015 and included a subaccounting of mean annual inflows and outflows for the portions of the aquifer that were upgradient and downgradient from the Mangum gage.

The numerical groundwater-flow model of the Salt Fork Red River aquifer was constructed by using MODFLOW-2005 with the Newton formulation solver. The model of the Salt Fork Red River aquifer was spatially discretized into 1,050 rows, 1,125 columns, about 170,000 active cells measuring 200 by 200 feet (ft), and a single convertible layer. The model was temporally discretized into 432 monthly transient stress periods (each with two time steps to improve model stability). An initial steady-state stress period represented mean annual inflows to, and outflows from, the aquifer and produced a solution that was used as the initial condition for subsequent transient stress periods as well as some groundwater-availability scenarios. The model was calibrated to water-table-altitude observations at selected wells and base-flow observations at selected streamgages.

The simulated saturated thickness of the Salt Fork Red River aquifer was determined by subtracting the altitude of the aquifer base from the simulated water-table altitude at the end of the numerical-model period (2015). The simulated saturated thickness was more than $75 \mathrm{ft}$ in a paleochannel in the Dodson terrace near the Texas border. The mean aquifer thickness (sum of saturated and unsaturated) was $49.62 \mathrm{ft}$, and the mean saturated thickness was $28.55 \mathrm{ft}$. A simulated 
mean transmissivity of 1,024 feet squared per day was computed from the calibrated hydraulic conductivity and saturated thickness of each cell. The simulated available water in storage at the end of the numerical-model period (2015) was 526,117 acre-feet (acre-ft); about 42 percent of that total was available upgradient from the Mangum gage, and about 58 percent of that total was available downgradient from the Mangum gage (including the Mangum terrace).

Three types of groundwater-availability scenarios were run using the calibrated numerical model. These scenarios were used to (1) estimate the EPS pumping rate that ensures a minimum 20-, 40-, and 50-year life of the aquifer, (2) quantify the potential effects of projected well withdrawals on groundwater storage over a 50-year period, and (3) simulate the potential effects of a hypothetical 10-year drought on base flow and groundwater storage. The 20-, 40-, and 50-year EPS pumping rates under normal recharge conditions were about $0.46,0.44$, and 0.44 acre-ft per acre per year, respectively. Given the 155,929-acre modeled aquifer area, these rates correspond to annual yields of about 71,700, 68,600, and $68,600 \mathrm{acre}-\mathrm{ft} / \mathrm{yr}$, respectively. For the 20 -year EPS scenario, decreasing and increasing recharge by 10 percent resulted in a 6-percent change in the EPS pumping rate in both cases; for the 40- and 50-year EPS scenarios, decreasing and increasing recharge by 10 percent resulted in a 7-percent change in the EPS pumping rate in both cases.

Projected 50-year pumping scenarios were used to simulate the effects of selected well withdrawal rates on groundwater storage of the Salt Fork Red River aquifer and base flows in the Salt Fork Red River. The effects of well withdrawals were evaluated by quantifying differences in groundwater storage and base flow in four 50-year scenarios, which applied (1) no groundwater pumping, (2) mean pumping rates for the study period (1980-2015), (3) 2015 pumping rates, and (4) increasing demand pumping rates at simulated wells. The increasing demand pumping rates assumed a cumulative 20.4-percent increase in pumping over 50 years based on 2010-60 demand projections for southwestern Oklahoma. Groundwater storage after 50 years with no pumping was 535,000 acre-ft, or 8,900 acre-ft (1.7 percent) greater than the initial groundwater storage; this groundwater storage increase is equivalent to a mean water-table-altitude increase of $0.48 \mathrm{ft}$. Groundwater storage after 50 years of pumping at the mean rate for the study period (1980-2015) was 519,900 acre-ft, or 6,200 acre-ft (1.2 percent) less than the initial groundwater storage; this groundwater storage decrease is equivalent to a mean water-table-altitude decline of $0.34 \mathrm{ft}$. Groundwater storage at the end of the 50-year period with 2015 pumping rates was 513,100 acre-ft, or 13,000 acre-ft (2.5 percent) less than the initial storage; this groundwater storage decrease is equivalent to a mean water-table-altitude decline of $0.71 \mathrm{ft}$. Groundwater storage at the end of the 50-year period with increasing demand pumping rates was 509,700 acre- $\mathrm{ft}$, or 16,500 acre-ft (3.1 percent) less than the initial storage; this groundwater storage decrease is equivalent to a mean watertable-altitude decline of $0.89 \mathrm{ft}$.
A hypothetical 10-year drought scenario was used to simulate the effects of a prolonged period of reduced recharge on groundwater storage. The period January 1983December 1992 was chosen as the simulated drought period. Drought effects were quantified by comparing the results of the drought scenario to those of the calibrated numerical model (no drought) at the end of the simulated drought period (1992). To simulate the hypothetical drought, recharge in the calibrated numerical model was reduced by 50 percent during the simulated drought period (1983-92). Upstream inflows from the Salt Fork Red River, Turkey Creek, and Bitter Creek were reduced by 75 percent. Groundwater storage at the end of the drought period (1992) was 479,200 acre-ft, or 53,200 acre- $\mathrm{ft}$ (10.0 percent) less than the groundwater storage of the calibrated numerical model at the end of the drought period. This decrease in groundwater storage is equivalent to a mean water-table-altitude decline of $2.9 \mathrm{ft}$. At the end of the 10-year hypothetical drought period, simulated base flows at the Mangum gage and USGS streamgage 07301110 Salt Fork Red River near Elmer, Okla., had decreased by about 80 and 70 percent, respectively.

\section{Introduction}

The 1973 Oklahoma Water Law (82 OK Stat $\S$ $82-1020.5)$ requires that the Oklahoma Water Resources Board (OWRB) conduct hydrologic investigations of the State's groundwater basins to support a determination of the maximum annual yield (MAY) for each groundwater basin. The MAY is defined as the amount of fresh groundwater that can be withdrawn annually while ensuring a minimum 20 -year life of the groundwater basin (OWRB, 2020b). For alluvium and terrace groundwater basins, the groundwater-basin-life requirement is satisfied if, after 20 years of MAY withdrawals, 50 percent of the groundwater basin (hereinafter referred to as an "aquifer") retains a saturated thickness of at least 5 feet (ft). Although 20 years is the minimum required by law, the OWRB can and often does consider multiple management scenarios. Once a MAY has been established, the amount of land owned or leased by a groundwater permit applicant determines the annual volume of water allocated to that groundwater permit applicant. The annual volume of groundwater allocated per acre of land is known as the equal-proportionate-share (EPS) pumping rate. At present (2021), the OWRB has not yet established a MAY and EPS pumping rate for the Salt Fork Red River aquifer (OWRB, 2020b); therefore, a default EPS pumping rate (2.0 acre-feet per acre per year) is currently in effect for that aquifer. To provide updated information to the OWRB that could support evaluation and determination of an appropriate MAY, the U.S. Geological Survey (USGS), in cooperation with the OWRB, conducted a hydrologic investigation and evaluated the effects of potential groundwater withdrawals on groundwater availability in the Salt Fork Red River aquifer. 


\section{Purpose and Scope}

The purpose of this report is to describe a hydrologic investigation of the Salt Fork Red River aquifer that included (1) an updated summary of the hydrogeology with a definition of a hydrogeologic framework of the aquifer, (2) development of conceptual and calibrated numerical groundwater-flow models for the aquifer representing the period 1980-2015, and (3) results of simulations of groundwater availability obtained by using the calibrated numerical groundwater-flow model. Groundwater-availability scenarios were performed by using the calibrated numerical groundwater-flow model to (1) estimate the EPS pumping rate that ensures a minimum 20-, 40-, and 50-year life of the aquifer, (2) quantify the potential effects of projected well withdrawals on groundwater storage over a 50 -year period, and (3) simulate the potential effects of a hypothetical (10-year) drought on groundwater storage. The calibrated numerical groundwater-flow model and groundwateravailability scenarios were archived and released in a USGS data release (Smith and others, 2021).

The geographic scope of the hydrologic investigation is the extent of alluvium and terrace deposits that compose the Salt Fork Red River aquifer. Although the alluvium and terrace deposits of the Salt Fork Red River extend into Texas (where they are known as the Seymour aquifer), this investigation was focused exclusively on the OWRB jurisdictional extent of the Salt Fork Red River aquifer in southwestern Oklahoma (fig. 1). Although sometimes referred to as the "Salt Fork of the Red River alluvial aquifer" (OWRB, 2019b), the aquifer is referred to as the "Salt Fork Red River aquifer" in this report because it consists not only of alluvium deposits but also of terrace and dune deposits.

\section{Description of Study Area}

The Salt Fork Red River aquifer in Greer, Harmon, and Jackson Counties of southwestern Oklahoma is composed of about 274.5 square miles $\left(\mathrm{mi}^{2}\right)$ of alluvium and terrace deposits associated with the Salt Fork Red River (fig. 1). In some parts of the study area, the terrace deposits occur as lobes that are either disconnected or partially connected to the active alluvium (the strip of recently mobilized and mostly unvegetated sediments along the present [2021] course of the Salt Fork Red River). The largest of these lobes are the high terrace deposits north of Hollis, Okla., hereinafter referred to as the "Dodson terrace," and the high terrace deposits around Mangum, Okla., hereinafter referred to as the "Mangum terrace" (fig. 1). Two smaller terrace lobes are to the west and southwest of the Mangum terrace (hereinafter referred to as the "Mulberry Creek terrace" and "Horse Branch terrace," respectively). The low terrace deposits west of Altus, Okla., hereinafter referred to as the "Martha terrace," are connected to the active alluvium deposits of the Salt Fork Red River.

The Salt Fork Red River and tributaries drain about $1,854 \mathrm{mi}^{2}$ (computed by using USGS StreamStats [Smith and Esralew, 2010; Ries and others, 2017]) of land area in Texas and Oklahoma before joining with the Red River (fig. 2). Some parts of the Salt Fork Red River, including that monitored by USGS streamgage 07300500 Salt Fork Red River at Mangum, Okla. (hereinafter referred to as the "Mangum gage") (fig. 1, table 1), have periods of no flow (defined as streamflow less than 1 cubic foot per second $\left[\mathrm{ft}^{3} / \mathrm{s}\right]$ to account for error in the stage-discharge rating approach used to generate streamflow hydrographs) in the late summer and during droughts when water demands for irrigation, public supply, and evapotranspiration are greatest. The Salt Fork Red River has only two perennial tributaries in Oklahoma (Horizon Systems Corporation, 2015); Turkey Creek and Bitter Creek join the Salt Fork Red River just north of Elmer in Jackson County (fig. 1). Bitter Creek drains parts of the Lugert-Altus Irrigation District, which delivers water from Lake Altus at a mean rate of about 50,000 acre-feet per year (acre-ft/yr) to a system of lined and unlined canals and laterals that supply flood-and drip-irrigation to about 48,000 acres of primarily cotton (Bureau of Reclamation, 2005; fig. 2). About 15 percent of the Lugert-Altus Irrigation District overlies the Salt Fork Red River aquifer, so about 7,500 acre-feet (acre-ft) of water is estimated to be delivered annually to lands overlying the aquifer.

Land cover over the aquifer is mostly shrubland and crops, which account for 47.6 and 39.3 percent of land cover, respectively (Fry and others, 2011; Multi-Resolution Land Characteristics Consortium, 2011; fig. 3). Shrubland is the predominant cover in the western part of the aquifer, and crops are the predominant cover in the eastern part of the aquifer. Although crop types may change annually with economic and hydrologic factors, the areal percentages of total crop cover and individual crop types did not change much over the period 2010-17 (National Agricultural Statistics Service, 2019); winter wheat (77.1 percent) and cotton (17.3 percent) together accounted for nearly 95 percent of crop cover over the aquifer (fig. 3). The frost-free growing season is about 210 days and lasts from April to October (National Agricultural Statistics Service, 2015; Oklahoma Climatological Survey, 2015). Most crops including corn, cotton, peanuts, sorghum, and canola are grown in this season, but winter wheat is planted in the early fall and harvested in June. The length of the growing season and the water requirement for crops in any year, however, can vary with the climate characteristics of that year (Masoner and others, 2003). Only 3.3 percent of the land cover is forest, which occurs mostly in small upland drainages overlying the western part of the aquifer or along the Salt Fork Red River in the eastern part of the aquifer (fig. 3). The study area is almost entirely rural, and only 4.2 percent of the land cover is developed (roads and towns). Mangum, Okla., is the only town with a population greater than 1,000 that overlies the Salt Fork Red River aquifer (U.S. Census Bureau, 2014). Although Mangum does not use water from the Salt Fork Red River aquifer, other towns rely (or historically relied) on the aquifer for public supply. The largest of those towns is Hollis, Okla., with a 2010 population of 2,060 (U.S. Census Bureau, 2014). For the period 1980-2015, groundwater use by Hollis averaged about 547 acre-ft/yr (Christopher Neel, OWRB, written commun., 2017). 


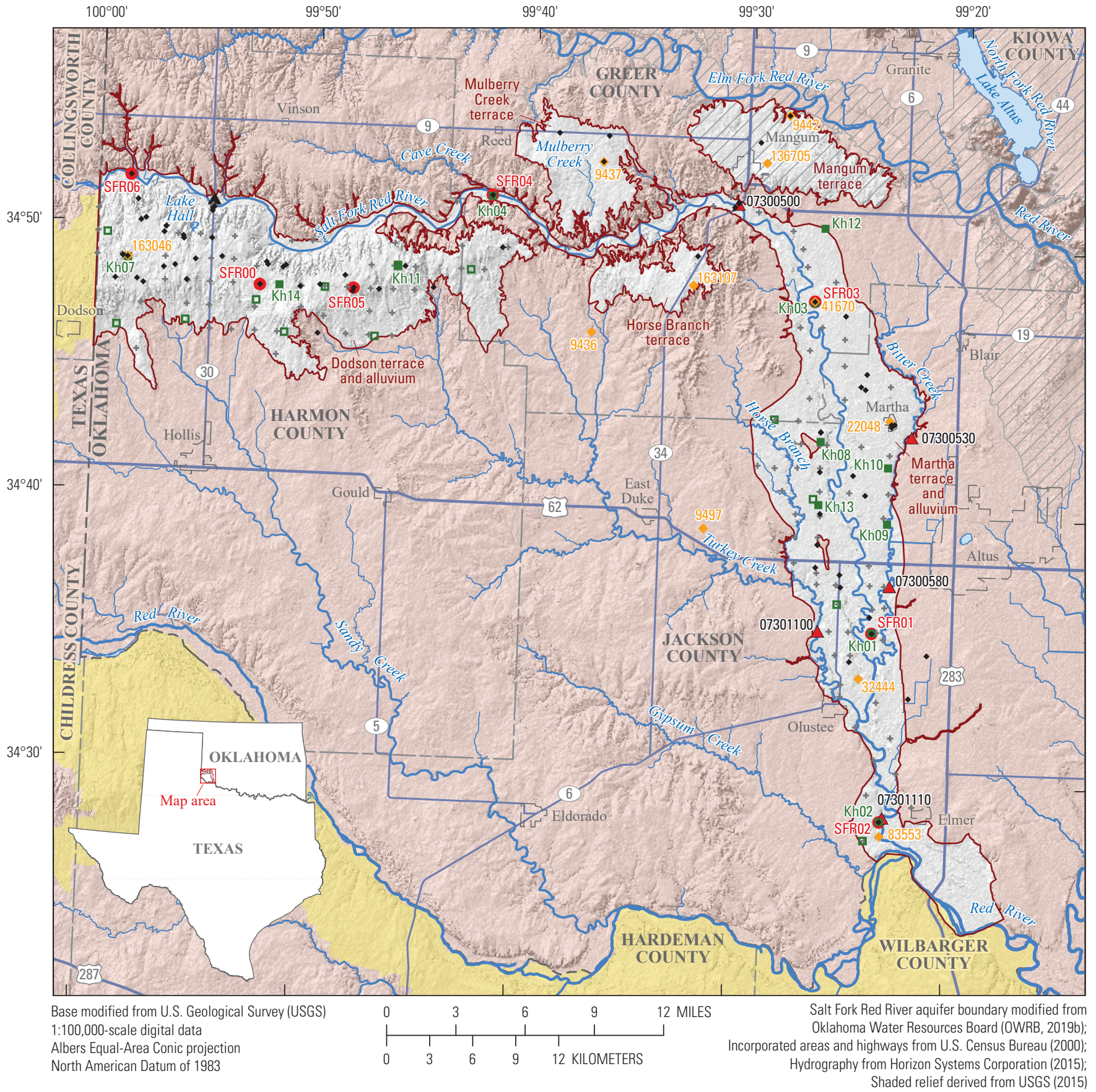

EXPLANATION

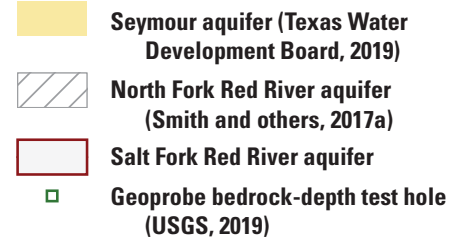

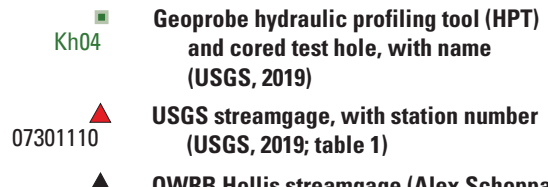

A OWRB Hollis streamgage (Alex Schoppa, OWRB, written commun., 2018)

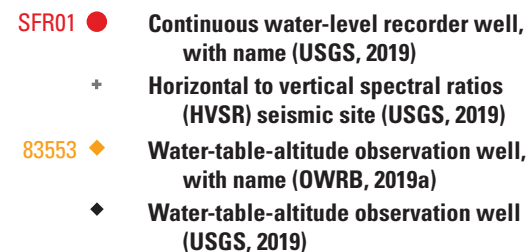
(USGS, 2019)

Figure 1. Map of the study area showing the extent of the Salt Fork Red River aquifer, southwestern Oklahoma. 
Table 1. Selected data-collection stations in and near the Salt Fork Red River aquifer study area, southwestern Oklahoma.

[M/D/Y, month/day/year; NAVD 88, North American Vertical Datum of 1988; >, greater than; USGS, U.S. Geological Survey; SFR2, Streamflow-Routing package, version 2; WTF, water-table fluctuation method; SWB, Soil-Water Balance; --, not applicable or unknown; SFRR, Salt Fork Red River aquifer; DCBG, Dog Creek Shale or Blaine Formation; OWRB, Oklahoma Water Resources Board. USGS (2019) data can be accessed using the 8- or 15-digit station number or other identifier. A more detailed and longer version of this table is available in the associated data release (Smith and others, 2021)]

\begin{tabular}{|c|c|c|c|c|c|c|c|c|c|c|c|c|c|c|c|}
\hline \multirow{2}{*}{$\begin{array}{c}\text { Station } \\
\text { number or } \\
\text { identifier } \\
\text { (fig. 1) }\end{array}$} & \multirow{2}{*}{$\begin{array}{l}\text { Short name for } \\
\text { station or other } \\
\text { identifier }\end{array}$} & \multirow{2}{*}{ Station name } & \multirow{2}{*}{$\begin{array}{c}\text { Latitude, } \\
\text { in } \\
\text { decimal } \\
\text { degrees }\end{array}$} & \multirow{2}{*}{$\begin{array}{l}\text { Longitude, } \\
\text { in decimal } \\
\text { degrees }\end{array}$} & \multirow{2}{*}{ County } & \multicolumn{2}{|c|}{$\begin{array}{l}\text { Period of record (may } \\
\text { contain gaps) or } \\
\text { single measurement } \\
\text { date }(M / D / Y)\end{array}$} & \multirow{2}{*}{$\begin{array}{l}\text { Land- } \\
\text { surface } \\
\text { altitude, } \\
\text { in feet } \\
\text { above } \\
\text { NAVD } 88\end{array}$} & \multirow{2}{*}{$\begin{array}{c}\text { Well } \\
\text { or } \\
\text { hole } \\
\text { depth, } \\
\text { in feet }\end{array}$} & \multirow{2}{*}{$\begin{array}{l}\text { Aquifer } \\
\text { or geo- } \\
\text { logic } \\
\text { unit }\end{array}$} & \multicolumn{3}{|c|}{$\begin{array}{l}\text { Drainage area, in } \\
\text { square miles }\end{array}$} & \multirow{2}{*}{$\begin{array}{c}\text { Regulated } \\
\text { (>20 percent } \\
\text { of con- } \\
\text { tributing } \\
\text { drainage } \\
\text { area behind } \\
\text { large dams; } \\
\text { Lewis and } \\
\text { Esralew } \\
\text { [2009]) }\end{array}$} & \multirow{2}{*}{$\begin{array}{c}\text { Use in } \\
\text { numerical } \\
\text { groundwater- } \\
\text { flow model }\end{array}$} \\
\hline & & & & & & Begin & End & & & & Total & $\begin{array}{l}\text { Contri- } \\
\text { buting }\end{array}$ & $\begin{array}{l}\text { cont- } \\
\text { ributing }\end{array}$ & & \\
\hline \multicolumn{16}{|c|}{ Continuous-record streamgages (USGS, 2019) } \\
\hline 07299670 & Quanah gage & $\begin{array}{l}\text { Groesbeck } \\
\text { Creek } \\
\text { at State } \\
\text { Highway } \\
6 \text { near } \\
\text { Quanah, } \\
\text { Tex. }\end{array}$ & 34.3545 & -99.7404 & Hardeman & 12/1/1961 & $\begin{array}{l}\text { present } \\
\text { (2015) }\end{array}$ & -- & -- & -- & 303 & 303 & 0 & no & SFR2 inflow \\
\hline 07300000 & Wellington gage & $\begin{array}{l}\text { Salt Fork Red } \\
\text { River near } \\
\text { Wellington, } \\
\text { Tex. }\end{array}$ & 34.9576 & -100.2209 & $\begin{array}{l}\text { Collings- } \\
\text { worth }\end{array}$ & $6 / 8 / 1952$ & $\begin{array}{l}\text { present } \\
\quad(2015)\end{array}$ & -- & -- & -- & 1,222 & 1,222 & 0 & $\begin{array}{l}\text { yes; by } \\
\text { Greenbelt } \\
\text { Reservoir } \\
\text { since } \\
1967\end{array}$ & SFR2 inflow \\
\hline 07300500 & Mangum gage & $\begin{array}{l}\text { Salt Fork Red } \\
\text { River at } \\
\text { Mangum, } \\
\text { Okla. }\end{array}$ & 34.8584 & -99.5087 & Greer & $10 / 1 / 1937$ & $\begin{array}{l}\text { present } \\
(2015)\end{array}$ & -- & -- & -- & 1,454 & 1,319 & 135 & no & Calibration \\
\hline 07300530 & Martha gage & $\begin{array}{l}\text { Bitter Creek } \\
\text { near } \\
\text { Martha, } \\
\text { Okla. }\end{array}$ & 34.7167 & -99.3695 & Jackson & $5 / 13 / 1998$ & $9 / 29 / 2005$ & -- & -- & -- & 43 & 43 & 0 & no & SFR2 inflow \\
\hline 07300580 & Altus gage & $\begin{array}{l}\text { Bitter Creek } \\
\text { west of } \\
\text { Altus, } \\
\text { Okla. }\end{array}$ & 34.6234 & -99.3826 & Jackson & $4 / 25 / 1998$ & $9 / 29 / 2005$ & -- & -- & -- & 92 & 92 & 0 & no & $\begin{array}{l}\text { Manual } \\
\text { calibration } \\
\text { only }\end{array}$ \\
\hline 07301100 & Olustee gage & $\begin{array}{l}\text { Turkey Creek } \\
\text { at Olustee, } \\
\text { Okla. }\end{array}$ & 34.5942 & -99.4368 & Jackson & $7 / 1 / 1960$ & 9/29/1963 & -- & -- & -- & 317 & 317 & 0 & no & $\begin{array}{l}\text { Manual } \\
\text { calibration } \\
\text { only }\end{array}$ \\
\hline
\end{tabular}


Table 1. Selected data-collection stations in and near the Salt Fork Red River aquifer study area, southwestern Oklahoma.-Continued

[M/D/Y, month/day/year; NAVD 88, North American Vertical Datum of 1988; >, greater than; USGS, U.S. Geological Survey; SFR2, Streamflow-Routing package, version 2; WTF, water-table fluctuation method; SWB, Soil-Water Balance; --, not applicable or unknown; SFRR, Salt Fork Red River aquifer; DCBG, Dog Creek Shale or Blaine Formation; OWRB, Oklahoma Water Resources Board. USGS (2019) data can be accessed using the 8- or 15-digit station number or other identifier. A more detailed and longer version of this table is available in the associated data release (Smith and others, 2021)]

\begin{tabular}{|c|c|c|c|c|c|c|c|c|c|c|c|c|c|c|c|}
\hline \multirow{2}{*}{$\begin{array}{l}\text { Station } \\
\text { number or } \\
\text { identifier } \\
\text { (fig. 1) }\end{array}$} & \multirow{2}{*}{$\begin{array}{l}\text { Short name for } \\
\text { station or other } \\
\text { identifier }\end{array}$} & \multirow{2}{*}{ Station name } & \multirow{2}{*}{$\begin{array}{c}\text { Latitude, } \\
\text { in } \\
\text { decimal } \\
\text { degrees }\end{array}$} & \multirow{2}{*}{$\begin{array}{c}\text { Longitude, } \\
\text { in decimal } \\
\text { degrees }\end{array}$} & \multirow{2}{*}{ County } & \multicolumn{2}{|c|}{$\begin{array}{c}\text { Period of record (may } \\
\text { contain gaps) or } \\
\text { single measurement } \\
\text { date (M/D/Y) }\end{array}$} & \multirow{2}{*}{$\begin{array}{l}\text { Land- } \\
\text { surface } \\
\text { altitude, } \\
\text { in feet } \\
\text { above } \\
\text { NAVD } 88\end{array}$} & \multirow{2}{*}{$\begin{array}{l}\text { Well } \\
\text { or } \\
\text { hole } \\
\text { depth, } \\
\text { in feet }\end{array}$} & \multirow{2}{*}{$\begin{array}{c}\text { Aquifer } \\
\text { or geo- } \\
\text { logic } \\
\text { unit }\end{array}$} & \multicolumn{3}{|c|}{$\begin{array}{l}\text { Drainage area, in } \\
\text { square miles }\end{array}$} & \multirow{2}{*}{$\begin{array}{c}\text { Regulated } \\
\text { (>20 percent } \\
\text { of con- } \\
\text { tributing } \\
\text { drainage } \\
\text { area behind } \\
\text { large dams; } \\
\text { Lewis and } \\
\text { Esralew } \\
\text { [2009]) }\end{array}$} & \multirow{2}{*}{$\begin{array}{c}\text { Use in } \\
\text { numerical } \\
\text { groundwater- } \\
\text { flow model }\end{array}$} \\
\hline & & & & & & Begin & End & & & & Total & $\begin{array}{l}\text { Contri- } \\
\text { buting }\end{array}$ & $\begin{array}{l}\text { cont- } \\
\text { ributing }\end{array}$ & & \\
\hline \multicolumn{16}{|c|}{ Continuous-record streamgages (USGS, 2019)—Continued } \\
\hline 07301110 & Elmer gage & $\begin{array}{l}\text { Salt Fork } \\
\text { Red River } \\
\text { near Elmer, } \\
\text { Okla. }\end{array}$ & 34.4790 & -99.3823 & Jackson & 10/1/1979 & $\begin{array}{l}\text { present } \\
\text { (2015) }\end{array}$ & -- & -- & -- & 1,983 & 1,848 & 135 & no & Calibration \\
\hline-- & Hollis gage & $\begin{array}{l}\text { Salt Fork Red } \\
\text { River near } \\
\text { Hollis, } \\
\text { Okla. }\end{array}$ & 34.8446 & -99.9127 & Harmon & $6 / 20 / 2015$ & $11 / 14 / 2017$ & -- & -- & -- & 1,314 & 1,179 & 135 & $\begin{array}{l}\text { yes; by } \\
\text { Greenbelt } \\
\text { Reservoir } \\
\text { since } \\
1967\end{array}$ & SFR2 inflow \\
\hline \multicolumn{16}{|c|}{ Continuous water-level recorder wells (USGS, 2019) } \\
\hline SFR00 & 344750099522601 & $\begin{array}{l}\text { 04N-25W-30 } \\
\text { BBAB } 1 \\
\text { Raymond } \\
\text { Hays } \\
\text { Recorder } \\
\text { Well }\end{array}$ & 34.7973 & -99.8743 & Harmon & $5 / 30 / 1986$ & $1 / 18 / 1989$ & $1,820.00$ & 50.0 & SFRR & -- & -- & -- & -- & $\begin{array}{r}\text { Recharge } \\
\text { (WTF) }\end{array}$ \\
\hline SFR01 & 343537099234301 & $\begin{array}{l}01 \mathrm{~N}-21 \mathrm{~W}-03 \\
\text { ABB } 1 \\
\text { SFR01 }\end{array}$ & 34.5937 & -99.3952 & Jackson & $4 / 1 / 2015$ & $5 / 12 / 2017$ & $1,334.39$ & 72.0 & SFRR & -- & -- & -- & -- & $\begin{array}{r}\text { Recharge } \\
\text { (WTF) }\end{array}$ \\
\hline SFR02 & 342835099230401 & $\begin{array}{l}\text { 01S-21W-15 } \\
\text { ABC } 1 \\
\text { SFR02 }\end{array}$ & 34.4764 & -99.3846 & Jackson & $4 / 1 / 2015$ & $7 / 6 / 2017$ & $1,268.94$ & 49.5 & SFRR & -- & -- & -- & -- & -- \\
\hline SFR03 & 344758099265101 & $\begin{array}{l}04 \mathrm{~N}-21 \mathrm{~W}-19 \\
\text { DCD } 1 \\
\text { SFR03 }\end{array}$ & 34.7994 & -99.4475 & Greer & $4 / 1 / 2015$ & $3 / 3 / 2017$ & $1,455.11$ & 55.0 & SFRR & -- & -- & -- & -- & $\begin{array}{r}\text { Recharge } \\
\text { (WTF) }\end{array}$ \\
\hline SFR04 & 345131099415301 & $\begin{array}{l}\text { 05N-24W-35 } \\
\text { DDC } 1 \\
\text { SFR04 }\end{array}$ & 34.8586 & -99.6981 & Greer & $4 / 1 / 2015$ & $3 / 15 / 2017$ & $1,591.59$ & 23.4 & SFRR & -- & -- & -- & -- & -- \\
\hline
\end{tabular}


Table 1. Selected data-collection stations in and near the Salt Fork Red River aquifer study area, southwestern Oklahoma.—Continued

[M/D/Y, month/day/year; NAVD 88, North American Vertical Datum of 1988; >, greater than; USGS, U.S. Geological Survey; SFR2, Streamflow-Routing package, version 2; WTF, water-table fluctuation method; SWB, Soil-Water Balance; --, not applicable or unknown; SFRR, Salt Fork Red River aquifer; DCBG, Dog Creek Shale or Blaine Formation; OWRB, Oklahoma Water Resources Board. USGS (2019) data can be accessed using the 8- or 15-digit station number or other identifier. A more detailed and longer version of this table is available in the associated data release (Smith and others, 2021)]

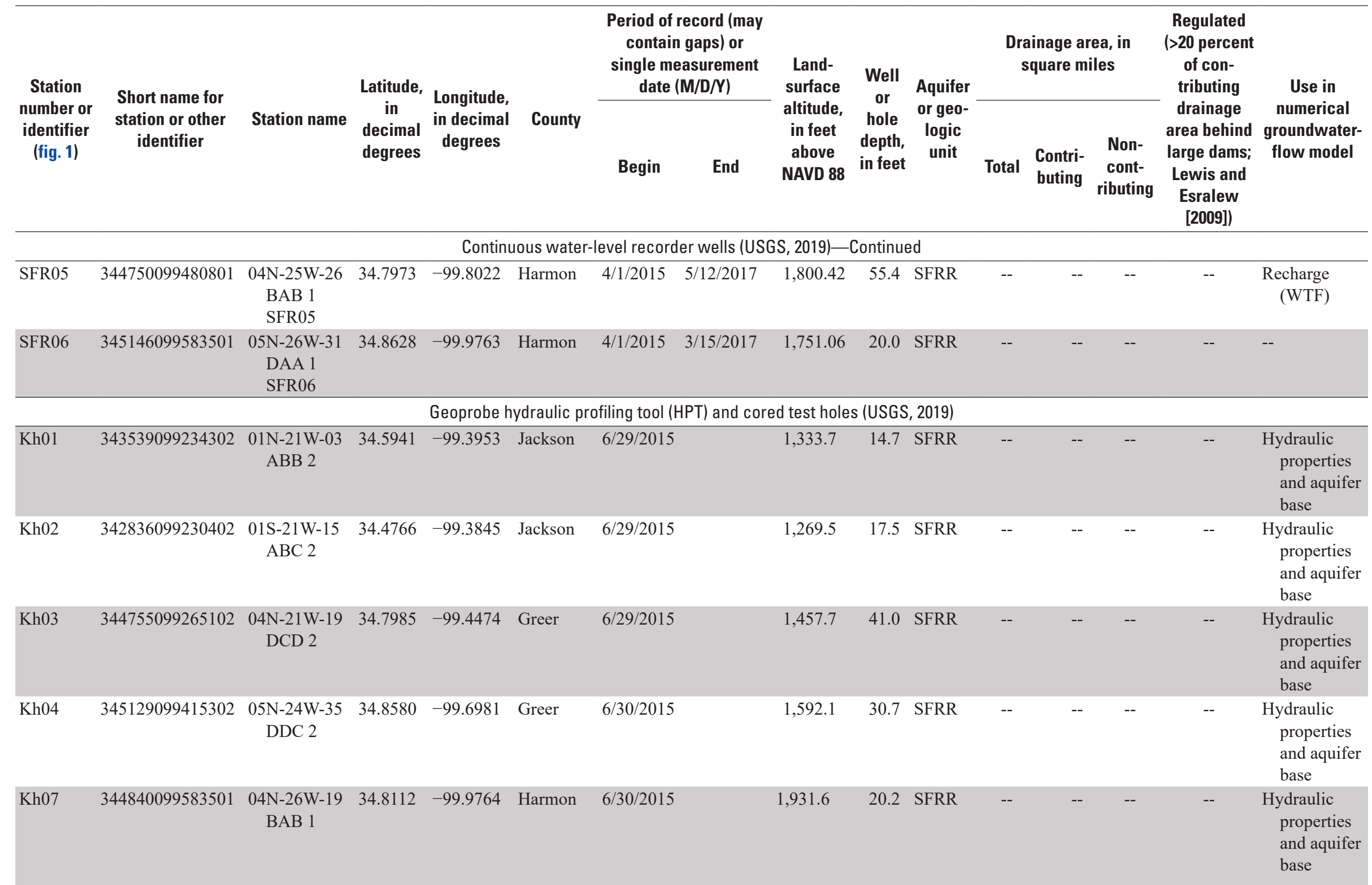


Table 1. Selected data-collection stations in and near the Salt Fork Red River aquifer study area, southwestern Oklahoma.-Continued

[M/D/Y, month/day/year; NAVD 88, North American Vertical Datum of 1988; >, greater than; USGS, U.S. Geological Survey; SFR2, Streamflow-Routing package, version 2; WTF, water-table fluctuation method; SWB, Soil-Water Balance; --, not applicable or unknown; SFRR, Salt Fork Red River aquifer; DCBG, Dog Creek Shale or Blaine Formation; OWRB, Oklahoma Water Resources Board. USGS (2019) data can be accessed using the 8- or 15-digit station number or other identifier. A more detailed and longer version of this table is available in the associated data release (Smith and others, 2021)]

\begin{tabular}{|c|c|c|c|c|c|c|c|c|c|c|c|c|c|c|}
\hline \multirow{2}{*}{$\begin{array}{l}\text { Station } \\
\text { number or } \\
\text { identifier } \\
\text { (fig. 1) }\end{array}$} & \multirow{2}{*}{$\begin{array}{l}\text { Short name for } \\
\text { station or other } \\
\text { identifier }\end{array}$} & \multirow{2}{*}{ Station name } & \multirow{2}{*}{$\begin{array}{l}\text { Latitude, } \\
\text { in } \\
\text { decimal } \\
\text { degrees }\end{array}$} & \multirow{2}{*}{$\begin{array}{c}\text { Longitude, } \\
\text { in decimal } \\
\text { degrees }\end{array}$} & \multirow{2}{*}{ County } & $\begin{array}{c}\text { Period of record (may } \\
\text { contain gaps) or } \\
\text { single measurement } \\
\text { date (M/D/Y) } \\
\end{array}$ & \multirow{2}{*}{$\begin{array}{l}\text { Land- } \\
\text { surface } \\
\text { altitude, } \\
\text { in feet } \\
\text { above } \\
\text { NAVD } 88\end{array}$} & \multirow{2}{*}{$\begin{array}{c}\text { Well } \\
\text { or } \\
\text { hole } \\
\text { depth, } \\
\text { in feet }\end{array}$} & \multirow{2}{*}{$\begin{array}{c}\text { Aquifer } \\
\text { or geo- } \\
\text { logic } \\
\text { unit }\end{array}$} & \multicolumn{3}{|c|}{$\begin{array}{l}\text { Drainage area, in } \\
\text { square miles }\end{array}$} & \multirow{2}{*}{$\begin{array}{c}\text { Regulated } \\
\text { (>20 percent } \\
\text { of con- } \\
\text { tributing } \\
\text { drainage } \\
\text { area behind } \\
\text { large dams; } \\
\text { Lewis and } \\
\text { Esralew } \\
\text { [2009]) }\end{array}$} & \multirow{2}{*}{$\begin{array}{l}\text { Use in } \\
\text { numerical } \\
\text { groundwater- } \\
\text { flow model }\end{array}$} \\
\hline & & & & & & Begin & & & & Total & $\begin{array}{l}\text { Contri- } \\
\text { buting }\end{array}$ & $\begin{array}{l}\text { Non- } \\
\text { cont- } \\
\text { ributing }\end{array}$ & & \\
\hline \multicolumn{15}{|c|}{ Geoprobe hydraulic profiling tool (HPT) and cored test holes (USGS, 2019_-Continued } \\
\hline Kh08 & 344244099262201 & $\begin{array}{l}03 \mathrm{~N}-21 \mathrm{~W}-20 \\
\text { CCB } 1\end{array}$ & 34.7123 & -99.4394 & Jackson & $6 / 29 / 2015$ & $1,436.5$ & 7.2 & SFRR & -- & -- & -- & -- & $\begin{array}{l}\text { Hydraulic } \\
\text { properties } \\
\text { and aquifer } \\
\text { base }\end{array}$ \\
\hline Kh09 & 343944099231001 & $\begin{array}{l}02 \mathrm{~N}-21 \mathrm{~W}-11 \\
\text { BCB } 1\end{array}$ & 34.6622 & -99.3862 & Jackson & $6 / 29 / 2015$ & $1,365.0$ & 13.4 & SFRR & -- & -- & -- & -- & $\begin{array}{l}\text { Hydraulic } \\
\text { properties } \\
\text { and aquifer } \\
\text { base }\end{array}$ \\
\hline Kh10 & 344150099231301 & $\begin{array}{l}03 \mathrm{~N}-21 \mathrm{~W}-27 \\
\text { DDD } 1\end{array}$ & 34.6972 & -99.3869 & Jackson & $6 / 29 / 2015$ & $1,383.9$ & 25.0 & SFRR & -- & -- & -- & -- & $\begin{array}{l}\text { Hydraulic } \\
\text { properties } \\
\text { and aquifer } \\
\text { base }\end{array}$ \\
\hline Kh11 & 344843099460801 & $\begin{array}{l}\text { 04N-24W-19 } \\
\text { BBA } 1\end{array}$ & 34.8119 & -99.7688 & Harmon & $6 / 30 / 2015$ & $1,787.5$ & 21.6 & SFRR & -- & -- & -- & -- & $\begin{array}{l}\text { Hydraulic } \\
\text { properties } \\
\text { and aquifer } \\
\text { base }\end{array}$ \\
\hline Kh12 & 345043099263001 & $\begin{array}{l}04 \mathrm{~N}-21 \mathrm{~W}-06 \\
\text { DDA } 1\end{array}$ & 34.8453 & -99.4416 & Greer & $6 / 29 / 2015$ & $1,519.8$ & 14.9 & SFRR & -- & -- & -- & -- & $\begin{array}{l}\text { Hydraulic } \\
\text { properties } \\
\text { and aquifer } \\
\text { base }\end{array}$ \\
\hline Kh13 & 344022099262201 & $\begin{array}{l}02 \mathrm{~N}-21 \mathrm{~W}-06 \\
\text { DAA } 1\end{array}$ & 34.6728 & -99.4393 & Jackson & $6 / 29 / 2015$ & $1,385.9$ & 31.4 & SFRR & -- & -- & -- & -- & $\begin{array}{l}\text { Hydraulic } \\
\text { properties } \\
\text { and aquifer } \\
\text { base }\end{array}$ \\
\hline Kh14 & 344751099513401 & $\begin{array}{l}04 \mathrm{~N}-25 \mathrm{~W}-29 \\
\text { BBB } 1\end{array}$ & 34.7976 & -99.8593 & Harmon & $6 / 30 / 2015$ & $1,835.8$ & 17.6 & SFRR & -- & -- & -- & -- & $\begin{array}{l}\text { Hydraulic } \\
\text { properties } \\
\text { and aquifer } \\
\text { base }\end{array}$ \\
\hline
\end{tabular}


Table 1. Selected data-collection stations in and near the Salt Fork Red River aquifer study area, southwestern Oklahoma.—Continued

[M/D/Y, month/day/year; NAVD 88, North American Vertical Datum of 1988; >, greater than; USGS, U.S. Geological Survey; SFR2, Streamflow-Routing package, version 2; WTF, water-table fluctuation method; SWB, Soil-Water Balance; --, not applicable or unknown; SFRR, Salt Fork Red River aquifer; DCBG, Dog Creek Shale or Blaine Formation; OWRB, Oklahoma Water Resources Board. USGS (2019) data can be accessed using the 8- or 15-digit station number or other identifier. A more detailed and longer version of this table is available in the associated data release (Smith and others, 2021)]

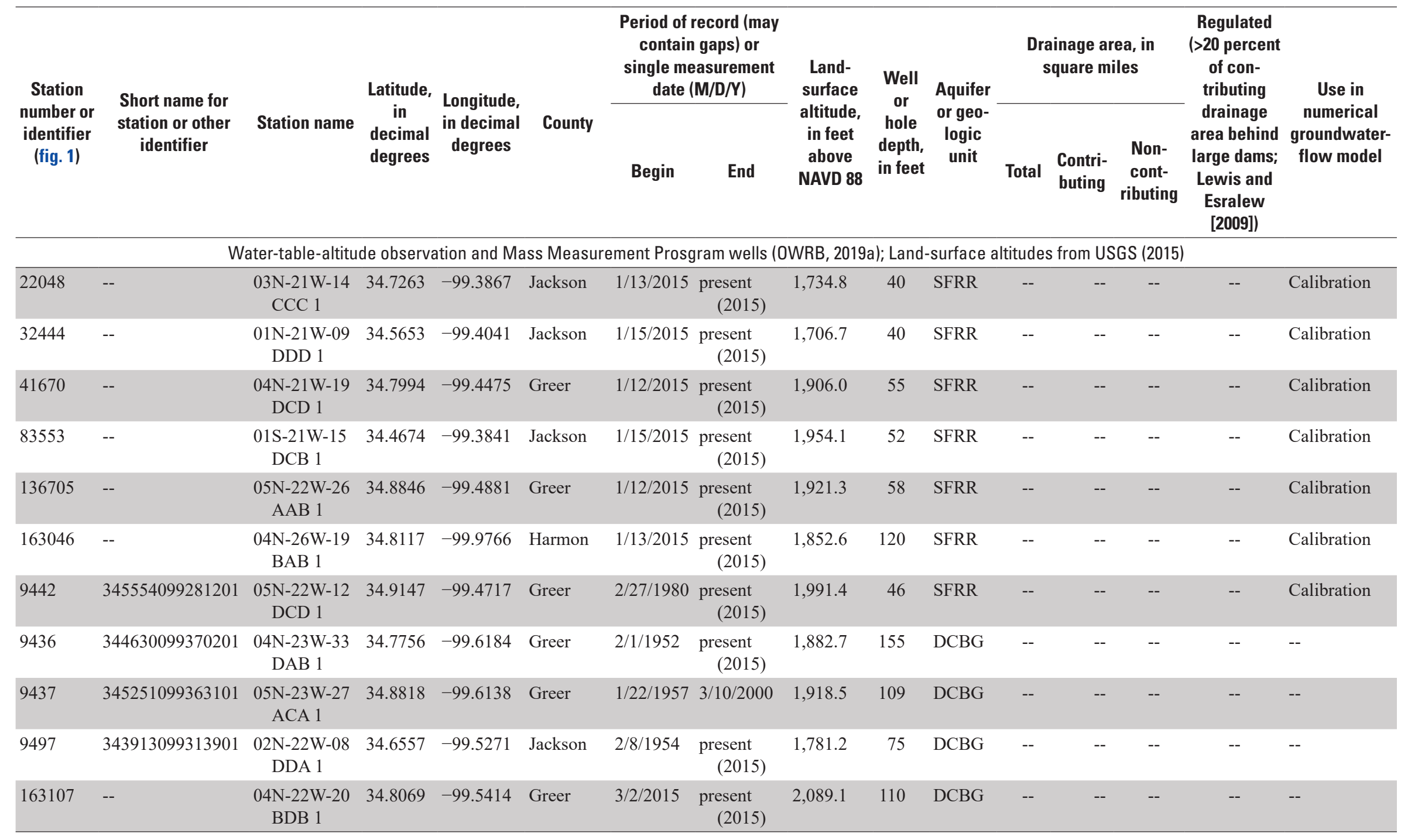




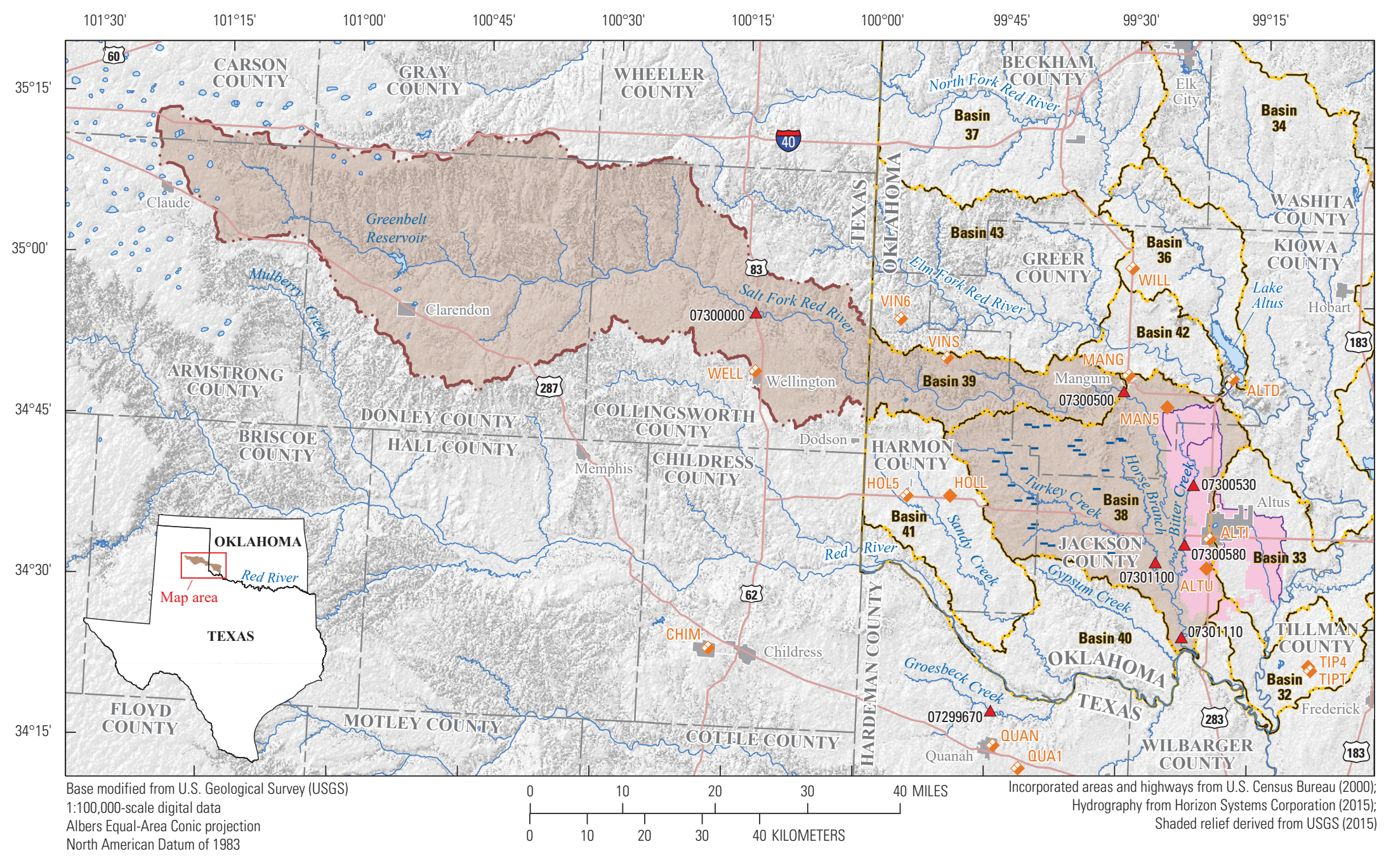

\section{EXPLANATION}

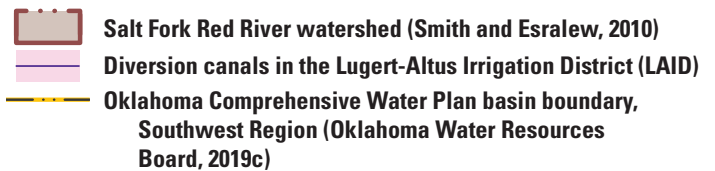

- Floodwater-retarding structure in the Salt Fork Red River watershed (Smith and Esralew, 2010)

Climate station, with name

USGS streamgage, with station number (USGS, 2019)

HOL5 National Climatic Data Center (2019a) TIP4 Oklahoma Mesonet (2019) Board, 2019c)

Figure 2. The major geographic and surface-water features in and near the Salt Fork Red River watershed, southwestern Oklahoma and northwestern Texas. 

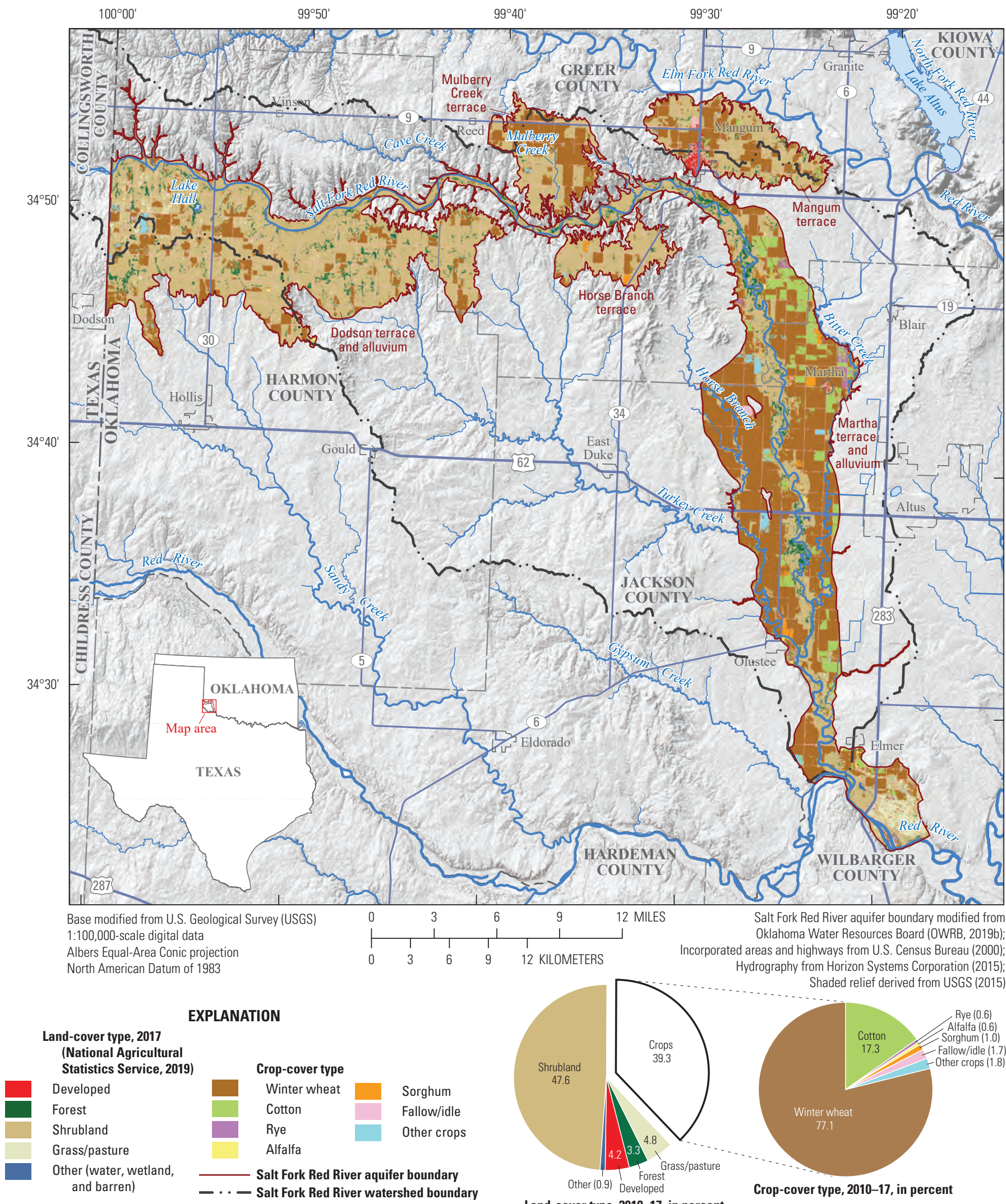

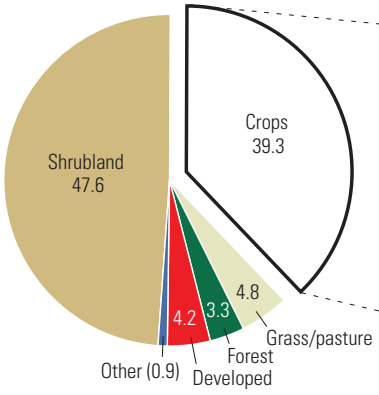

Land-cover type, 2010-17, in percent

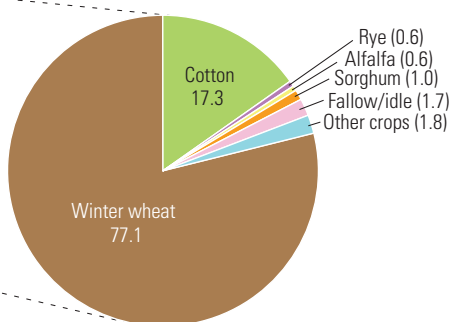

Crop-cover type, 2010-17, in percent

Components may not sum to 100 percent because of rounding.

Figure 3. Land and crop cover over the Salt Fork Red River aquifer, southwestern Oklahoma, 2010-17. 


\section{Climate Characteristics and Trends}

The Salt Fork Red River aquifer study area spans the 100th meridian, which forms the unofficial border between the semiarid southwest and semihumid southeast United States (Kottek and others, 2006). Daily maximum temperatures exceed 100 degrees Fahrenheit $\left({ }^{\circ} \mathrm{F}\right)$ for about $20-35$ days in summer, and the maximum recorded temperature was $120^{\circ} \mathrm{F}$ at Altus in 1936 (Oklahoma Climatological Survey, 2019). Daily minimum temperatures fall below $32^{\circ} \mathrm{F}$ for $60-80$ days in winter, and the minimum recorded temperature was $-11^{\circ} \mathrm{F}$ at Altus in 1947 (Oklahoma Climatological Survey, 2019). Historical data from selected climate stations in southwestern Oklahoma (Climate Division 7) have been quality assured and summarized monthly as part of the U.S. Historical Climatology Network (National Climatic Data Center, 2019b; figs. $4 A-B$, table 2 ). These monthly summarized data were used to calculate and graph annual and monthly temperature and precipitation statistics for the study area. A lowess smooth line (Cleveland, 1979) was used to delineate periods of belowand above-mean annual temperature and precipitation.

The mean annual precipitation in the study area for the period of record 1895-2017 was 27.8 inches per year (in/yr) (fig. $4 A$, table 2). A relatively long, predominantly dry period occurred during 1930-80 with 33 of 51 years (65 percent) recording below-mean precipitation. Within this dry period, years were grouped into four 5- to 12-year spans of belowmean precipitation punctuated by 3 - to 5 -year spans of abovemean precipitation. The mean annual precipitation in the study area for the study period 1980-2015 was $29.4 \mathrm{in} / \mathrm{yr}$ (fig. 4A, table 2). The period 1981-2000 was an unprecedented wet period in the available record in which 16 of 20 years ( 80 percent) had above-mean precipitation (fig. $4 A$ ). The period 2010-14 was noteworthy as an exceptionally dry period in which all 5 years had below-mean precipitation, whereas the period 2015-17 was an exceptionally wet period in which all 3 years had above-mean precipitation.

The mean annual temperature in the study area for the period of record $1895-2017$ was $61.2^{\circ} \mathrm{F}$ (fig. $4 B$, table 2). Compared to the period of record, the mean annual temperature was about $0.4^{\circ} \mathrm{F}$ greater and the mean annual precipitation was about $1.6 \mathrm{in} / \mathrm{yr}$ greater for the study period (1980-2015; v). Annual precipitation values were greater than the mean annual precipitation for the period of record in 21 of 36 years of the study period. The 20 -year wet period 1981-2000 and the 21-year (and continuing) warm period 1996-2017 were otherwise unprecedented in the period of record (figs. $4 A-B$ ).

The period of greatest monthly precipitation usually occurs in May and June, and a secondary period of greater monthly precipitation often occurs in September and October (fig. 5A). Monthly precipitation usually is lowest in the winter months, when snow totals of 1-10 inches (in.) are common (Oklahoma Climatological Survey, 2019). The mean monthly precipitation for the study period 1980-2015 was greatest (4.5 in.) in May and least (1.1 in.) in January (fig. $5 A$ ). The mean monthly temperature for the study period 1980-2015 was greatest $\left(84^{\circ} \mathrm{F}\right)$ in July and least $\left(39^{\circ} \mathrm{F}\right)$ in January (fig. $5 B$ ). Winds average about 10 miles per hour annually and are prevailingly from the south and southeast (Oklahoma Climatological Survey, 2019).

Multiyear to decadal droughts are common for the study area. The 1929-41 ("Dust Bowl"), 1952-56, and 1961-72 drought periods were among the most severe in Oklahoma in the 20th century; a short, less severe drought period also occurred in the late 20th century during 1976-81 (fig. 4A). The 21st century began with the 2002-06 and 2010-14 drought periods (Tortorelli, 2008; Shivers and Andrews, 2013) (fig. 4A). The most severe droughts on record developed from extended periods of below-mean precipitation paired with above-mean temperature. Climate models used by the Coupled Model Intercomparison Project 5 (CMIP5; World Climate Research Programme, 2020) predict an increase of about $5^{\circ} \mathrm{F}$ in annual minimum and maximum temperatures in the study area between the historical period 1950-2005 and the future period 2050-74 (Alder and Hostetler, 2013). These climate models also predict a slight decrease in mean annual precipitation between the historical period 1950-2005 and the future period 2050-74 (Alder and Hostetler, 2013). If future climate conditions match these predictions, they are likely to cause increased water demand in the study area, especially for irrigation; more water would be required to grow the same crops under the predicted warmer and drier climate conditions.

\section{Groundwater-Use Characteristics and Trends}

The OWRB permits and regulates groundwater use in Oklahoma, except for groundwater use less than 5 acre-ft/ $\mathrm{yr}$ for domestic and agricultural purposes and groundwater use for irrigating up to 3 acres of land for growing gardens, orchards, or lawns (82 OK Stat § 82-1020.3, 82-1020.1[2]). Groundwater-use data are self-reported annually to the OWRB by permitted users, and OWRB staff reviewed groundwateruse data described in this report to ensure the quality and completeness of the data (Christopher Neel, OWRB, written commun., 2017). In 2015, about 100 long-term temporary groundwater-use permits and about 100 prior-right groundwater-use permits were active for the Salt Fork Red River aquifer (OWRB, 2019d). Each permit may include multiple wells that share the allocated groundwater use. Nearly all groundwater-use permits were allocated for irrigation and public supply (figs. 6 and $7 A$, table 3). Most groundwateruse permits for irrigation were associated with wells and land areas in the Martha terrace (fig. 6). Groundwater use for domestic supply (self-supplied directly to homes by a private well) was assumed to be a negligible part of the total groundwater use because the population over the aquifer was small; if an estimated 2,000 domestic users living over the aquifer used groundwater at an estimated rate of 50 gallons per person per day, that domestic use would account for only 11 acre-ft/yr of groundwater. For the purposes of this report, all groundwater use was assumed to be consumptive use. 
Table 2. Mean annual precipitation and mean annual temperature for selected periods, southwestern Oklahoma (Climate Division 7), 1895-2017 (National Climatic Data Center, 2019b).

$\left[{ }^{\circ} \mathrm{F}\right.$, degrees Fahrenheit $]$

\begin{tabular}{llccc}
\hline \multicolumn{1}{c}{ Region name } & Period & Number of years & $\begin{array}{c}\text { Mean annual precipitation, } \\
\text { in inches per year }\end{array}$ & $\begin{array}{c}\text { Mean annual temperature, } \\
\text { in }{ }^{\circ} \mathbf{F}\end{array}$ \\
\hline $\begin{array}{l}\text { Southwestern Oklahoma } \\
\text { (Climate Division 7; }\end{array}$ & $1895-2017$ & 121 & 27.8 & 61.2 \\
National Climatic Data & $1904-1941$ & 38 & 27.7 & 61.1 \\
Center, 2019b) & $1942-1979$ & 38 & 26.6 & 60.9 \\
& $1980-2017$ & 38 & 29.7 & 61.7 \\
& $1980-2015$ & 36 & 29.4 & 61.6 \\
\hline
\end{tabular}

The population of the study area has steadily decreased since 1970 (U.S. Census Bureau, 2014), but annual groundwater use from the Salt Fork Red River aquifer increased by about 21 acre-ft/yr over the period of record 1967-2015 and by about 27 acre-ft/yr over the study period 1980-2015 according to the Theil-Sen slope estimator (Sen, 1968). Using the Kendall (1938) tau test and probability ( $p$-value) of greater than or equal to 0.0500 as the significance value, the upward trend for the period of record (1967-2015) was found to be statistically significant ( $p$-value $=0.0162)$, whereas for the study period (1980-2015) a statistically significant ( $p$-value $=0.0701$ ) upward trend was not detected. Mean annual groundwater use for the period of record 1967-2015 was 3,416.6 acre-ft/yr (table 3); about 79 percent of that groundwater use was for irrigation, and about 21 percent was for public supply. Mean annual groundwater use for the study period (1980-2015) was 3,532.7 acre-ft/yr (table 3); about 77 percent of that groundwater use was for irrigation, and about 23 percent was for public supply (fig. $7 \mathrm{~A}$ ). Mean annual groundwater use for the period 2010-15, which mostly coincided with drought conditions (figs. 4A-C), was 4,790.0 acre-ft/yr, or about 40 percent greater than the mean annual groundwater use for the period of record 1967-2015 (table 3).

Annual reported groundwater use was about 47 percent of the annual permitted groundwater use during the period of record (1967-2015; fig. 7B, table 3). Annual reported groundwater use during the recent period 2010-15, however, was about 56 percent of the annual permitted groundwater use for that period. Some individual users reported groundwater use that exceeded the permitted amount; if those reported amounts were reduced to match the permitted amounts, the reported water use for the period of record and study period would be about 13 percent (about 450 acre-ft/yr) less (fig. 7B). Most of the groundwater use during the period of record 1967-2015 was for irrigation in Jackson County (fig. 7C). Most of the increase in groundwater use over the recent period 2010-15, however, was for irrigation in Harmon County. Since 1984, groundwater use for public supply in Harmon County accounted for about 20 percent of total groundwater use in the Salt Fork Red River aquifer.

\section{Streamflow Characteristics and Trends}

Streamflow measured at streamgages is the sum of runoff and base flow originating upstream. Base flow is the component of streamflow that is supplied by the discharge of groundwater to streams (Barlow and Leake, 2012). For this report, USGS (2019) streamflow hydrograph data were separated into runoff and base-flow components by using the Base-Flow Index code (Wahl and Wahl, 1995) in the USGS Groundwater Toolbox (Barlow and others, 2015). The BaseFlow Index code uses the minimum streamflow in a moving $n$-day window as a basis for hydrograph separation; a 5-day window was used for all streamgages in this study. The 5-day window was selected by testing multiple $n$-day windows for the study period at the Mangum gage and plotting the resulting mean base-flow percentage against $n$; a slope change was evident at 5 days. Base flow, as computed using this method, accounts for about 33.5-37.8 percent of annual streamflow for the period of record at streamgages on the Salt Fork Red River main stem (table 4). This percentage, known as the base-flow index (BFI), generally increased over the study period 1980-2015 at streamgages on the Salt Fork Red River (figs. 8A-C). When summarized annually using the Kendall (1938) tau test with the Theil-Sen (Sen, 1968) slope estimator, the upward trends in BFI were found to be statistically significant $(p$-value $=0.0005)$ at USGS streamgage 07300000 Salt Fork Red River near Wellington, Tex. (hereinafter referred to as the "Wellington gage"), not statistically significant ( $p$-value $=0.3403$ ) at the Mangum gage, and statistically significant $(p$-value $=0.0498)$ at USGS streamgage 07301110 Salt Fork Red River near Elmer, Okla. (hereinafter referred to as the "Elmer gage").

Streamflow and base flow in the Salt Fork Red River vary with climate conditions. Days to months of no flow are typical for most years at the Wellington and Mangum gages and for the driest years at the Elmer gage (figs. $8 A-C$ ). The 2010-14 drought period, however, caused an unusually long, 4-year period of reduced streamflow in the Salt Fork Red River. Almost no base flow was recorded at these streamgages from early 2011 until early 2015 when a wet spring ended that drought. 

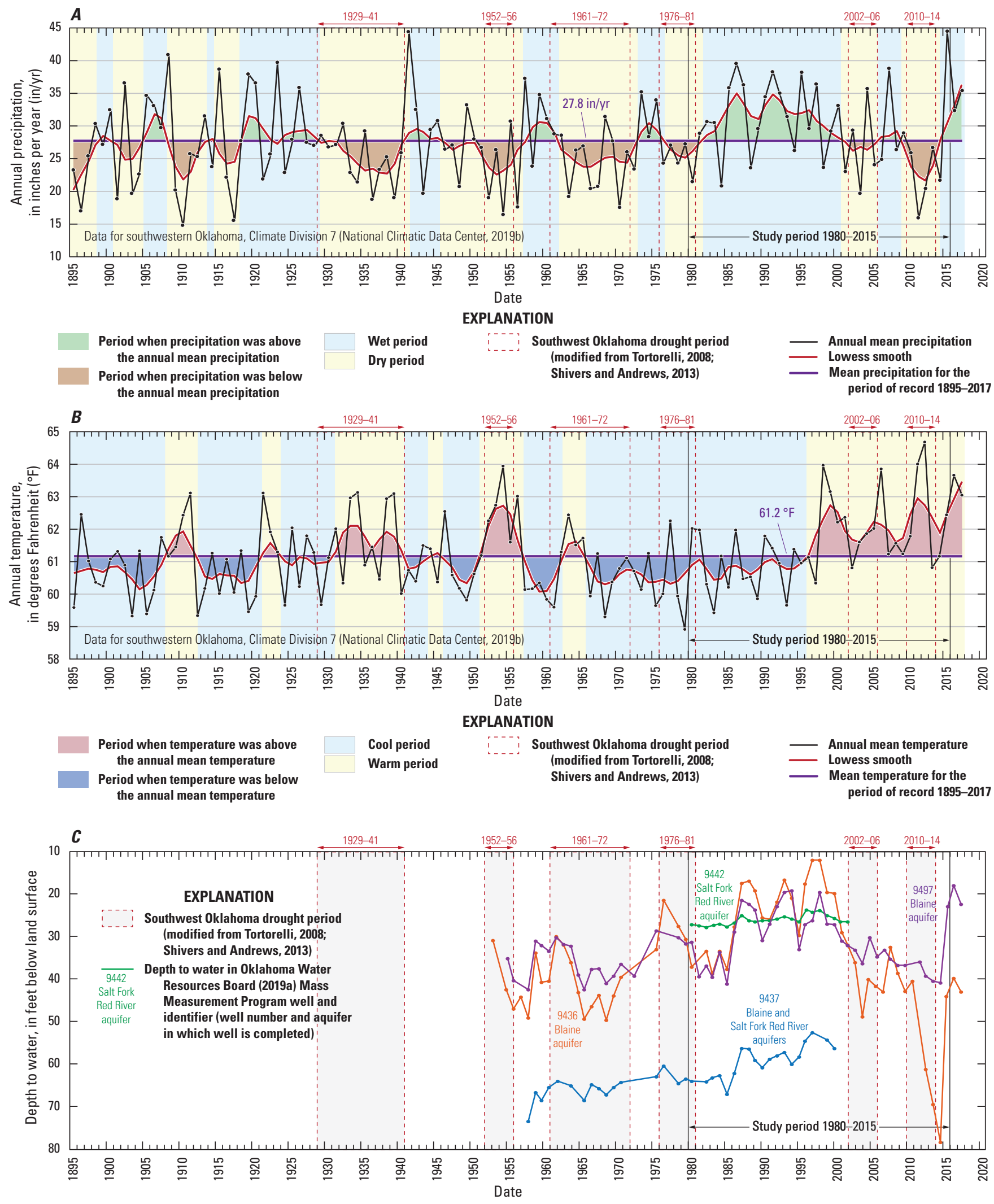

Figure 4. $A$, Annual precipitation; $B$, annual temperature; and $C$, depth to water in selected wells, southwestern Oklahoma, $1895-2017$. 

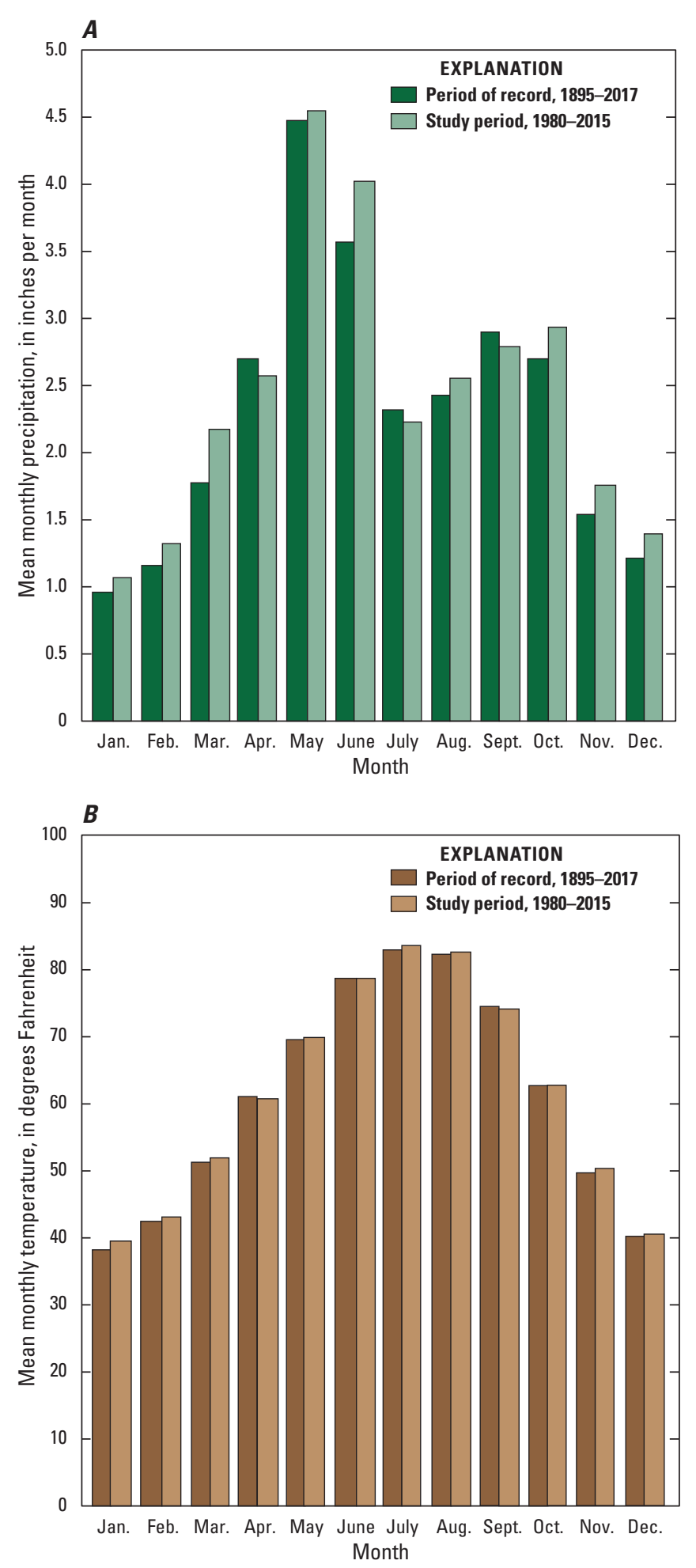

Figure 5. $\quad A$, Mean monthly precipitation; and $B$, mean monthly temperature, southwestern Oklahoma (Climate Division 7), 1895-2017 and 1980-2015 (National Climatic Data Center, 2019b).

\section{Hydrogeology of the Salt Fork Red River Aquifer}

The Salt Fork Red River aquifer lies on the northeastern limb of the Hollis Basin (syncline; Northcutt and Campbell, 1995; fig. 9). The Hollis Basin was formed by the Wichita Uplift, which accounted for the exposure of granites of Cambrian age in the northeastern part of the study area (Johnson, 1990). The units of Permian age (fig. 10) that underlie the aquifer dip gently to the southwest (figs. $11 \mathrm{~A}-\mathrm{C}$ ), toward the synclinal axis that runs from Dodson, Tex., past and to the south of Elmer, Okla. (fig. 9). The Dodson terrace overlies the Whitehorse Group and Dog Creek Shale of Permian age (fig. 11A). The Dodson terrace is likely connected to the active alluvium of the Salt Fork Red River in some areas, but the Permian-age bedrock units partially separate the Dodson terrace and the active alluvium in other areas. The Mangum terrace and most of the Martha terrace overlie the Hennessey Group of Permian age, but the Martha terrace also overlies the Flower-pot Shale and Duncan Sandstone of Permian age in some areas (figs. $11 B-C$ ). Faults are present at depth in the bedrock of pre-Permian age in the study area (fig. 9; Stanley, 2004; Stanley and Miller, 2004; Marsh and Holland, 2016), but they are unlikely to continue into the alluvium and terrace deposits or affect groundwater flow in the Salt Fork Red River aquifer.

\section{Alluvium and Terrace Deposits of Quaternary Age}

The alluvium and terrace deposits of Quaternary age associated with the Salt Fork Red River have not been previously studied in detail. These deposits are likely composed of discontinuous and poorly sorted layers of clay, silt, sand, and gravel and are similar to other alluvial deposits in and near the study area (Barclay and Burton, 1953; Burton, 1965; Hollowell, 1965a, b; Smith and others, 2017a). Steele and Barclay (1965) described the terrace deposits west of the Salt Fork Red River in Jackson County as thin and almost entirely composed of clay derived from bedrock units of Permian age. The Salt Fork Red River deposits were suspected to be, on average, slightly finer grained and less permeable than those of the nearby North Fork Red River (Smith and others, 2017a; fig. 1) based on the relative scarcity of gravel references in available lithologic logs (OWRB, 2019a) from the Salt Fork Red River aquifer. Well-yield data availability was insufficient to allow for statistical analysis, but wells in the Salt Fork Red River aquifer are suspected to be less productive than wells in the nearby North Fork Red River aquifer to the north. Steele and Barclay (1965) theorized that well yields of as much as 300 gallons per minute (gal/min) might be possible in the Salt Fork Red River aquifer. 
Table 3. Annual reported groundwater use from the Salt Fork Red River aquifer, 1967-2015.

[Data from the Oklahoma Water Resources Board (OWRB) water-use database (Christopher Neel, OWRB, written commun., 2017). Table excludes groundwater use of less than 5 acre-feet per year for domestic and agricultural purposes and groundwater use for irrigation of fewer than 3 acres of land for growing of gardens, orchards, or lawns (82 OK Stat § 82-1020.3). "Other" includes use for industrial, power, mining, commercial, and recreation, fish, and wildlife. All values are in acre-feet per year]

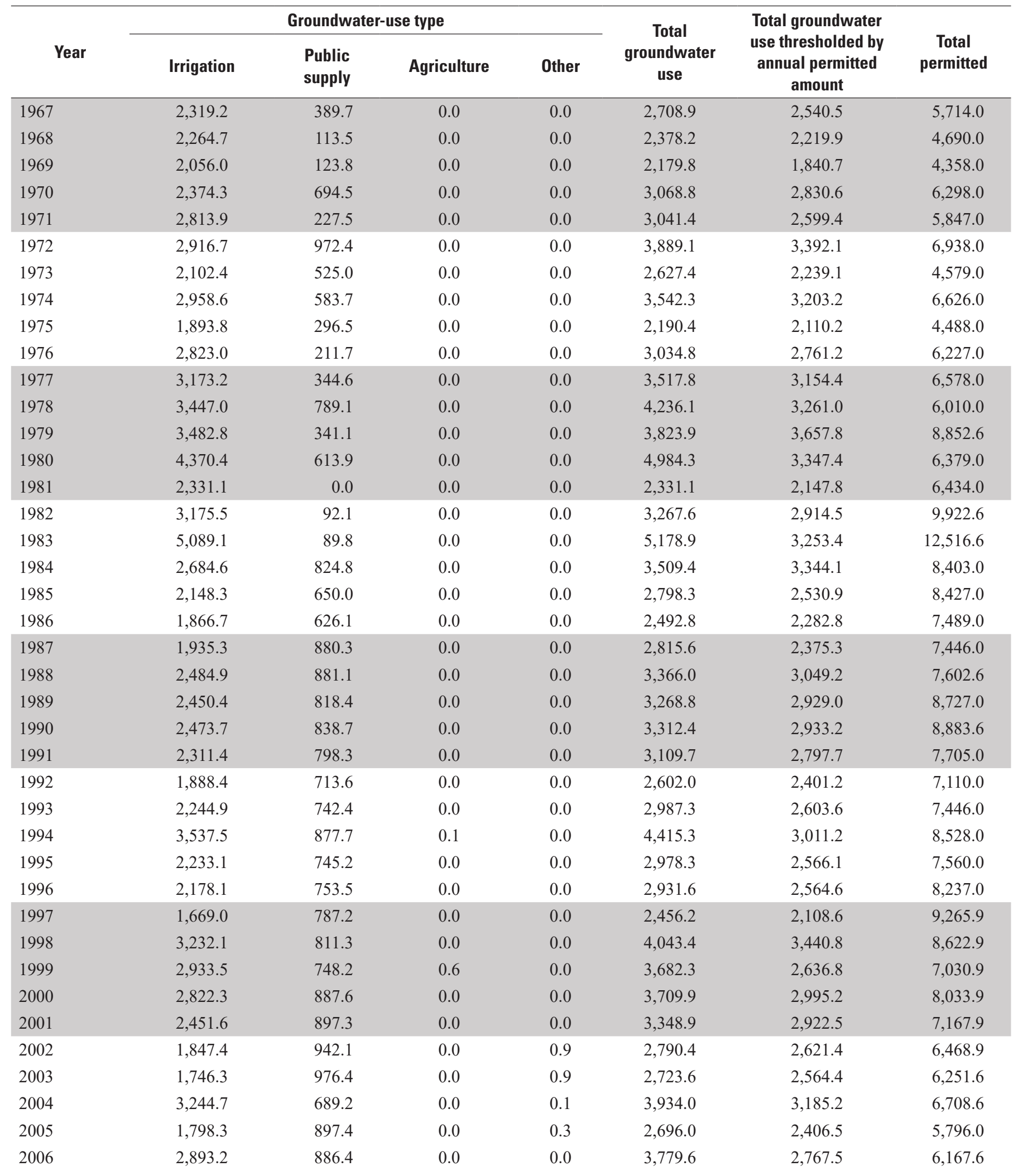


Table 3. Annual reported groundwater use from the Salt Fork Red River aquifer, 1967-2015. - Continued

[Data from the Oklahoma Water Resources Board (OWRB) water-use database (Christopher Neel, OWRB, written commun., 2017). Table excludes groundwater use of less than 5 acre-feet per year for domestic and agricultural purposes and groundwater use for irrigation of fewer than 3 acres of land for growing of gardens, orchards, or lawns (82 OK Stat § 82-1020.3). "Other" includes use for industrial, power, mining, commercial, and recreation, fish, and wildlife. All values are in acre-feet per year]

\begin{tabular}{|c|c|c|c|c|c|c|c|}
\hline \multirow[b]{2}{*}{ Year } & \multicolumn{4}{|c|}{ Groundwater-use type } & \multirow{2}{*}{$\begin{array}{c}\text { Total } \\
\text { groundwater } \\
\text { use }\end{array}$} & \multirow{2}{*}{$\begin{array}{c}\text { Total groundwater } \\
\text { use thresholded by } \\
\text { annual permitted } \\
\text { amount } \\
\end{array}$} & \multirow[b]{2}{*}{$\begin{array}{c}\text { Total } \\
\text { permitted }\end{array}$} \\
\hline & Irrigation & $\begin{array}{l}\text { Public } \\
\text { supply }\end{array}$ & Agriculture & Other & & & \\
\hline 2007 & $1,942.3$ & $1,052.3$ & 0.0 & 0.0 & $2,994.6$ & $2,855.7$ & $6,217.6$ \\
\hline 2008 & $2,455.8$ & $1,060.5$ & 0.0 & 0.0 & $3,516.3$ & $3,284.6$ & $5,881.6$ \\
\hline 2009 & $1,862.4$ & 548.4 & 0.0 & 0.2 & $2,411.0$ & $2,391.0$ & $5,913.6$ \\
\hline 2010 & $3,223.4$ & $1,031.3$ & 0.0 & 0.0 & $4,254.7$ & $4,129.2$ & $7,722.6$ \\
\hline 2011 & $3,601.0$ & $1,233.2$ & 0.0 & 0.0 & $4,834.2$ & $4,581.4$ & $7,212.6$ \\
\hline 2012 & $3,893.2$ & $1,539.0$ & 0.0 & 0.0 & $5,432.2$ & $4,940.9$ & $8,210.6$ \\
\hline 2013 & $3,199.2$ & $1,057.4$ & 0.0 & 0.0 & $4,256.6$ & $4,077.8$ & $8,666.6$ \\
\hline 2014 & $2,858.5$ & $1,070.2$ & 0.0 & 0.0 & $3,928.7$ & $3,745.0$ & $8,214.9$ \\
\hline 2015 & $4,870.4$ & $1,163.4$ & 0.0 & 0.0 & $6,033.8$ & $5,843.0$ & $11,463.6$ \\
\hline $\begin{array}{r}\text { Mean annual, } \\
1967-2015\end{array}$ & $2,705.6$ & 711.0 & 0.0 & 0.0 & $3,416.6$ & $2,986.9$ & $7,286.5$ \\
\hline $\begin{array}{r}\text { Mean annual, } \\
1980-2015\end{array}$ & $2,720.8$ & 811.8 & 0.0 & 0.1 & $3,532.7$ & $3,070.8$ & $7,773.2$ \\
\hline $\begin{array}{l}\text { Mean annual, } \\
2010-15\end{array}$ & $3,607.6$ & $1,182.4$ & 0.0 & 0.0 & $4,790.0$ & $4,552.9$ & $8,581.8$ \\
\hline
\end{tabular}

\section{Bedrock Units}

The Dodson terrace unconformably overlies the Whitehorse Group, Dog Creek Shale, and Blaine Formation of Permian age (fig. 11A). The Whitehorse Group is composed of gypsiferous fine-grained sandstone and siltstone. About 50 miles northeast of the study area, the upper unit of the Whitehorse Group (Rush Springs Formation) has sufficient extent, thickness, and permeability to serve as an important aquifer (Rush Springs aquifer) for public and irrigation supply (Ellis, 2018; Neel and others, 2018). The Dog Creek Shale, which directly underlies much of the Dodson terrace (fig. 11A), is composed primarily of gypsiferous shale interbedded with some siltstone, fine-grained sandstone, and dolomite (fig. 10). The Dog Creek Shale likely acts as a less permeable confining unit than the Whitehorse Group.

The Blaine Formation of Permian age directly underlies much of the active alluvium of the Salt Fork Red River upstream from Mangum (fig. 9), as well as the majority of the Horse Branch terrace (fig. 11B). The Blaine Formation primarily is composed of massive gypsum beds interbedded with dolomite and shale. Where exposed or nearly exposed at land surface, the Blaine Formation is characterized by sinkholes and other dissolution features. In some parts of the study area, like the area between Hollis and Eldorado, these salt-karst features are well developed and continuous enough for the Blaine Formation to serve as an important aquifer for irrigation supply. Based on scant water-level data from distant observation wells in the area just west of Mangum (fig. 1), the water table in the Blaine Formation (fig. 4C) may be below the streambed of the Salt Fork Red River in that area.

The Mangum terrace and Martha terrace are primarily underlain by the Flower-pot Shale, Duncan Sandstone, and Hennessey Group of Permian age (figs. $11 B$ and $11 C$, respectively). The Duncan Sandstone is relatively thin in the study area, and because it is generally more resistant to weathering than the overlying Flower-pot Shale and underlying Hennessey Group, the Duncan Sandstone forms small bluffs that constrict the alluvium and terrace deposits of Quaternary age near Elmer, Okla. (fig. 9). Isolated outcrops of the Duncan Sandstone are surrounded by terrace deposits just west of the Salt Fork Red River in the Martha terrace. Those outcrops represent the remnants of what appears to be a partially buried ridgeline that roughly parallels Horse Branch (figs. 9 and $11 C$ ). Outcrops of the Duncan Sandstone are only found in Jackson County because the unit thins to the north. 


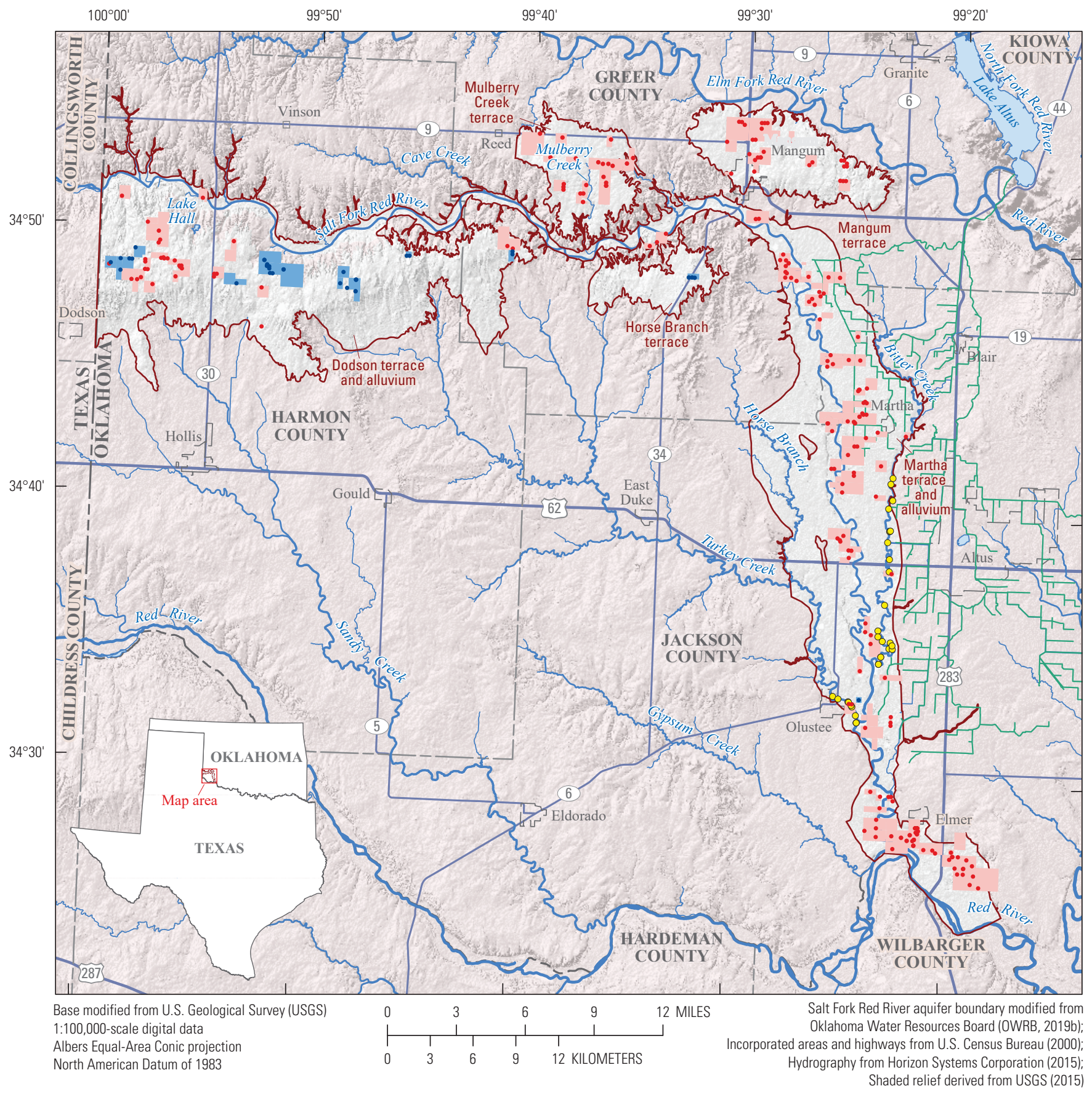

EXPLANATION

Salt Fork Red River aquifer

Allocated groundwater rights-Permitted land area (Oklahoma Water Resources Board, 2019d) Irrigation

Public supply

Lugert-Altus Irrigation District canal or lateral (Oklahoma Water Resources Board, 2019a)

\author{
Well with permitted groundwater use (Oklahoma \\ Water Resources Board, 2019d) \\ - Irrigation \\ - Production \\ - Permitted surface-water diversion (Oklahoma Water \\ Resources Board, 2019d)
}

Figure 6. Land areas and wells permitted for groundwater use from the Salt Fork Red River aquifer, southwestern Oklahoma, 2015. 

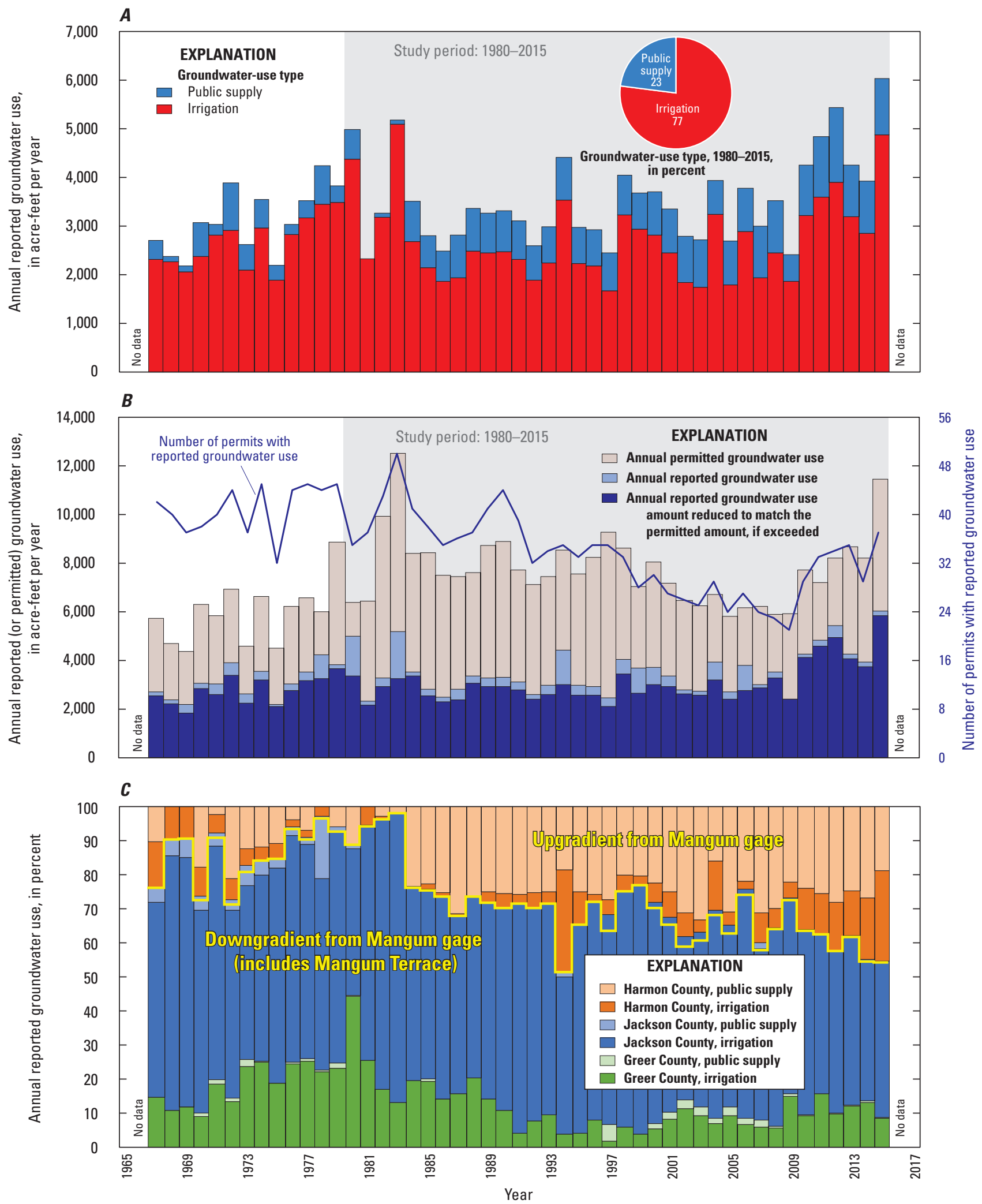

Data from Oklahoma Water Resources Board (OWRB) water-use database (Christopher Neel, OWRB, written commun., 2017) Mangum gage refers to U.S. Geological Survey streamgage 07300500 Salt Fork Red River at Mangum, Okla.

Figure 7. Annual reported groundwater use from the Salt Fork Red River aquifer, southwestern Oklahoma, 1967-2015, $A$, for public supply or irrigation; $B$, delineated as permitted and reported; and $C$, upgradient or downgradient from Mangum gage. 
Table 4. Annual mean streamflow, base flow, and base-flow index values for selected U.S. Geological Survey streamgages in and near the Salt Fork Red River aquifer study area, 1980-2017.

[ft3/s, cubic foot per second; \%, percent; BFI, base-flow index; --, data not available; acre-ft/yr, acre-foot per year. Values computed by using the BFI code (Wahl and Wahl, 1995) in the U.S. Geological Survey Groundwater Toolbox (Barlow and others, 2015). Streamgage locations are shown on figure 2, and streamgage information is listed in table 1]

\begin{tabular}{|c|c|c|c|c|c|c|c|c|c|c|c|c|c|c|c|c|c|c|}
\hline \multirow{3}{*}{ Year } & \multicolumn{3}{|c|}{$\begin{array}{c}07300000 \text { Salt Fork Red } \\
\text { River near Wellington, } \\
\text { Tex. }\end{array}$} & \multicolumn{3}{|c|}{$\begin{array}{l}07300500 \text { Salt Fork Red } \\
\text { River at Mangum, Okla. }\end{array}$} & \multicolumn{3}{|c|}{$\begin{array}{c}07300530 \text { Bitter Creek } \\
\text { near Martha, Okla. }\end{array}$} & \multicolumn{3}{|c|}{$\begin{array}{c}07300580 \text { Bitter Creek } \\
\text { west of Altus, Okla. }\end{array}$} & \multicolumn{3}{|c|}{$\begin{array}{l}07301110 \text { Salt Fork Red } \\
\text { River near Elmer, Okla. }\end{array}$} & \multicolumn{3}{|c|}{$\begin{array}{c}07299670 \text { Groesbeck } \\
\text { Creek at State Highway } \\
6 \text { near Quanah, Tex. }\end{array}$} \\
\hline & \multirow{2}{*}{$\begin{array}{l}\text { Mean } \\
\text { streamflow, } \\
\text { in } \mathrm{ft}^{3} / \mathrm{s}\end{array}$} & \multicolumn{2}{|c|}{$\begin{array}{l}\text { Mean base } \\
\text { flow }\end{array}$} & \multirow{2}{*}{$\begin{array}{c}\text { Mean } \\
\text { stream- } \\
\text { flow, in } \\
\text { ft } 3 / s\end{array}$} & \multicolumn{2}{|c|}{$\begin{array}{l}\text { Mean base } \\
\text { flow }\end{array}$} & \multirow{2}{*}{$\begin{array}{c}\text { Mean } \\
\text { stream- } \\
\text { flow, in } \\
\mathrm{ft}^{3} / \mathrm{s}\end{array}$} & \multicolumn{2}{|c|}{$\begin{array}{l}\text { Mean base } \\
\text { flow }\end{array}$} & \multirow{2}{*}{$\begin{array}{c}\text { Mean } \\
\text { stream- } \\
\text { flow, in } \\
\text { ft } 3 / s\end{array}$} & \multicolumn{2}{|c|}{$\begin{array}{l}\text { Mean base } \\
\text { flow }\end{array}$} & \multirow{2}{*}{$\begin{array}{c}\text { Mean } \\
\text { stream- } \\
\text { flow, in } \\
\text { ft } 3 / s\end{array}$} & \multicolumn{2}{|c|}{$\begin{array}{l}\text { Mean base } \\
\text { flow }\end{array}$} & \multirow{2}{*}{$\begin{array}{c}\text { Mean } \\
\text { stream- } \\
\text { flow, in } \\
\mathrm{ft} 3 / \mathrm{s}\end{array}$} & \multicolumn{2}{|c|}{$\begin{array}{l}\text { Mean base } \\
\text { flow }\end{array}$} \\
\hline & & $\mathrm{ft}^{3} / \mathrm{s}$ & $\begin{array}{c}\% \\
\text { (BFI) }\end{array}$ & & $\mathrm{ft}^{3} / \mathrm{s}$ & $\begin{array}{c}\% \\
\text { (BFI) }\end{array}$ & & $\mathrm{ft}^{3} / \mathrm{s}$ & $\begin{array}{c}\% \\
\text { (BFI) }\end{array}$ & & $\mathrm{ft}^{3} / \mathrm{s}$ & $\begin{array}{c}\% \\
\text { (BFI) }\end{array}$ & & $\mathrm{ft}^{3} / \mathrm{s}$ & $\begin{array}{c}\% \\
\text { (BFI) }\end{array}$ & & $\mathrm{ft}^{3} / \mathrm{s}$ & $\begin{array}{c}\% \\
\text { (BFI) }\end{array}$ \\
\hline 1938 & -- & -- & -- & 161.6 & 4.9 & 3.0 & -- & -- & -- & -- & -- & -- & -- & -- & -- & -- & -- & -- \\
\hline 1939 & -- & -- & -- & 80.6 & 5.3 & 6.6 & -- & -- & -- & -- & -- & -- & -- & -- & -- & -- & -- & -- \\
\hline 1940 & -- & -- & -- & 14.7 & 0.6 & 4.3 & -- & -- & -- & -- & -- & -- & -- & -- & -- & -- & -- & -- \\
\hline 1941 & -- & -- & -- & 324.6 & 21.8 & 6.7 & -- & -- & -- & -- & -- & -- & -- & -- & -- & -- & -- & -- \\
\hline 1942 & -- & -- & -- & 88.6 & 15.2 & 17.1 & -- & -- & -- & -- & -- & -- & -- & -- & -- & -- & -- & -- \\
\hline 1943 & -- & -- & -- & 27.0 & 5.6 & 20.8 & -- & -- & -- & -- & -- & -- & -- & -- & -- & -- & -- & -- \\
\hline 1944 & -- & -- & -- & 78.0 & 8.6 & 11.1 & -- & -- & -- & -- & -- & -- & -- & -- & -- & -- & -- & -- \\
\hline 1945 & -- & -- & -- & 39.5 & 7.5 & 19.0 & -- & -- & -- & -- & -- & -- & -- & -- & -- & -- & -- & -- \\
\hline 1946 & -- & -- & -- & 56.8 & 3.5 & 6.2 & -- & -- & -- & -- & -- & -- & -- & -- & -- & -- & -- & -- \\
\hline 1947 & -- & -- & -- & 151.3 & 4.8 & 3.2 & -- & -- & -- & -- & -- & -- & -- & -- & -- & -- & -- & -- \\
\hline 1948 & -- & -- & -- & 48.5 & 2.7 & 5.5 & -- & -- & -- & -- & -- & -- & -- & -- & -- & -- & -- & -- \\
\hline 1949 & -- & -- & -- & 96.7 & 16.4 & 16.9 & -- & -- & -- & -- & -- & -- & -- & -- & -- & -- & -- & -- \\
\hline 1950 & -- & -- & -- & 57.1 & 12.3 & 21.5 & -- & -- & -- & -- & -- & -- & -- & -- & -- & -- & -- & -- \\
\hline 1951 & -- & -- & -- & 60.3 & 8.7 & 14.5 & -- & -- & -- & -- & -- & -- & -- & -- & -- & -- & -- & -- \\
\hline 1952 & -- & -- & -- & 13.9 & 5.7 & 41.1 & -- & -- & -- & -- & -- & -- & -- & -- & -- & -- & -- & -- \\
\hline 1953 & 61.8 & 8.0 & 12.9 & 74.3 & 2.7 & 3.6 & -- & -- & -- & -- & -- & -- & -- & -- & -- & -- & -- & -- \\
\hline 1954 & 112.1 & 11.5 & 10.2 & 101.6 & 8.1 & 8.0 & -- & -- & -- & -- & -- & -- & -- & -- & -- & -- & -- & -- \\
\hline 1955 & 88.3 & 8.7 & 9.8 & 128.6 & 2.0 & 1.6 & -- & -- & -- & -- & -- & -- & -- & -- & -- & -- & -- & -- \\
\hline 1956 & 37.6 & 3.6 & 9.6 & 104.1 & 1.6 & 1.5 & -- & -- & -- & -- & -- & -- & -- & -- & -- & -- & -- & -- \\
\hline 1957 & 163.3 & 10.2 & 6.2 & 191.7 & 30.9 & 16.1 & -- & -- & -- & -- & -- & -- & -- & -- & -- & -- & -- & -- \\
\hline 1958 & 78.9 & 9.8 & 12.4 & 77.6 & 11.1 & 14.3 & -- & -- & -- & -- & -- & -- & -- & -- & -- & -- & -- & -- \\
\hline 1959 & 72.6 & 8.5 & 11.7 & 99.2 & 7.6 & 7.6 & -- & -- & -- & -- & -- & -- & -- & -- & -- & -- & -- & -- \\
\hline 1960 & 128.5 & 25.4 & 19.8 & 188.5 & 37.4 & 19.8 & -- & -- & -- & -- & -- & -- & -- & -- & -- & -- & -- & -- \\
\hline 1961 & 64.3 & 13.6 & 21.2 & 78.5 & 18.3 & 23.3 & -- & -- & -- & -- & -- & -- & -- & -- & -- & -- & -- & -- \\
\hline 1962 & 69.2 & 14.0 & 20.2 & 82.5 & 11.9 & 14.4 & -- & -- & -- & -- & -- & -- & -- & -- & -- & 37.1 & 6.0 & 16.3 \\
\hline
\end{tabular}


Table 4. Annual mean streamflow, base flow, and base-flow index values for selected U.S. Geological Survey streamgages in and near the Salt Fork Red River aquifer study area, 1980-2017.-Continued

[ft $3 / \mathrm{s}$, cubic foot per second; \%, percent; BFI, base-flow index; --, data not available; acre-ft/yr, acre-foot per year. Values computed by using the BFI code (Wahl and Wahl, 1995) in the U.S. Geological Survey Groundwater Toolbox (Barlow and others, 2015). Streamgage locations are shown on figure 2, and streamgage information is listed in table 1]

\begin{tabular}{|c|c|c|c|c|c|c|c|c|c|c|c|c|c|c|c|c|c|c|}
\hline \multirow{3}{*}{ Year } & \multicolumn{3}{|c|}{$\begin{array}{c}07300000 \text { Salt Fork Red } \\
\text { River near Wellington, } \\
\text { Tex. }\end{array}$} & \multicolumn{3}{|c|}{$\begin{array}{l}07300500 \text { Salt Fork Red } \\
\text { River at Mangum, Okla. }\end{array}$} & \multicolumn{3}{|c|}{$\begin{array}{c}07300530 \text { Bitter Creek } \\
\text { near Martha, Okla. }\end{array}$} & \multicolumn{3}{|c|}{$\begin{array}{c}07300580 \text { Bitter Creek } \\
\text { west of Altus, Okla. }\end{array}$} & \multicolumn{3}{|c|}{$\begin{array}{l}07301110 \text { Salt Fork Red } \\
\text { River near Elmer, Okla. }\end{array}$} & \multicolumn{3}{|c|}{$\begin{array}{c}07299670 \text { Groesbeck } \\
\text { Creek at State Highway } \\
6 \text { near Quanah, Tex. }\end{array}$} \\
\hline & \multirow{2}{*}{$\begin{array}{l}\text { Mean } \\
\text { streamflow, } \\
\text { in } \mathrm{ft}^{3} / \mathrm{s}\end{array}$} & \multicolumn{2}{|c|}{$\begin{array}{c}\text { Mean base } \\
\text { flow }\end{array}$} & \multirow{2}{*}{$\begin{array}{c}\text { Mean } \\
\text { stream- } \\
\text { flow, in } \\
\mathrm{ft} 3 / \mathrm{s}\end{array}$} & \multicolumn{2}{|c|}{$\begin{array}{c}\text { Mean base } \\
\text { flow }\end{array}$} & \multirow{2}{*}{$\begin{array}{c}\text { Mean } \\
\text { stream- } \\
\text { flow, in } \\
\mathrm{ft}^{3} / \mathrm{s}\end{array}$} & \multicolumn{2}{|c|}{$\begin{array}{c}\text { Mean base } \\
\text { flow }\end{array}$} & \multirow{2}{*}{$\begin{array}{c}\text { Mean } \\
\text { stream- } \\
\text { flow, in } \\
\text { ft } 3 / s\end{array}$} & \multicolumn{2}{|c|}{$\begin{array}{c}\text { Mean base } \\
\text { flow }\end{array}$} & \multirow{2}{*}{$\begin{array}{c}\text { Mean } \\
\text { stream- } \\
\text { flow, in } \\
\text { ft3/s }\end{array}$} & \multicolumn{2}{|c|}{$\begin{array}{l}\text { Mean base } \\
\text { flow }\end{array}$} & \multirow{2}{*}{$\begin{array}{c}\text { Mean } \\
\text { stream- } \\
\text { flow, in } \\
\mathrm{ft} 3 / \mathrm{s}\end{array}$} & \multicolumn{2}{|c|}{$\begin{array}{c}\text { Mean base } \\
\text { flow }\end{array}$} \\
\hline & & $\mathrm{ft}^{3} / \mathrm{s}$ & $\begin{array}{c}\% \\
\text { (BFI) }\end{array}$ & & $\mathrm{ft}^{3} / \mathbf{s}$ & $\%$ (BFI) & & $\mathrm{ft}^{3} / \mathrm{s}$ & $\begin{array}{c}\% \\
\text { (BFI) }\end{array}$ & & $\mathrm{ft}^{3} / \mathrm{s}$ & $\begin{array}{c}\% \\
\text { (BFI) }\end{array}$ & & $\mathrm{ft}^{3} / \mathrm{s}$ & $\begin{array}{c}\% \\
\text { (BFI) }\end{array}$ & & $f^{3} / s$ & $\begin{array}{c}\% \\
\text { (BFI) }\end{array}$ \\
\hline 1963 & 35.6 & 9.7 & 27.1 & 50.1 & 5.9 & 11.8 & -- & -- & -- & -- & -- & -- & -- & -- & -- & 7.7 & 3.6 & 46.5 \\
\hline 1964 & 31.5 & 9.4 & 29.7 & 41.6 & 4.4 & 10.6 & -- & -- & -- & -- & -- & -- & -- & -- & -- & 3.4 & 1.7 & 49.9 \\
\hline 1965 & 53.1 & 10.0 & 18.9 & 99.4 & 12.5 & 12.5 & -- & -- & -- & -- & -- & -- & -- & -- & -- & 32.7 & 1.6 & 4.8 \\
\hline 1966 & 18.8 & 8.7 & 46.0 & 42.0 & 5.6 & 13.4 & -- & -- & -- & -- & -- & -- & -- & -- & -- & 5.0 & 2.1 & 40.8 \\
\hline 1967 & 21.6 & 6.9 & 32.0 & 49.0 & 2.4 & 4.9 & -- & -- & -- & -- & -- & -- & -- & -- & -- & 3.8 & 1.1 & 29.7 \\
\hline 1968 & 77.1 & 15.2 & 19.7 & 174.3 & 11.9 & 6.8 & -- & -- & -- & -- & -- & -- & -- & -- & -- & 3.8 & 1.3 & 33.0 \\
\hline 1969 & 44.6 & 14.0 & 31.5 & 112.7 & 12.2 & 10.8 & -- & -- & -- & -- & -- & -- & -- & -- & -- & 9.3 & 1.3 & 13.7 \\
\hline 1970 & 15.7 & 7.6 & 48.4 & 31.6 & 4.7 & 15.0 & -- & -- & -- & -- & -- & -- & -- & -- & -- & 3.8 & 1.5 & 39.1 \\
\hline 1971 & 14.4 & 5.7 & 39.8 & 21.0 & 3.4 & 16.4 & -- & -- & -- & -- & -- & -- & -- & -- & -- & 16.5 & 1.1 & 6.7 \\
\hline 1972 & 34.5 & 9.9 & 28.7 & 29.0 & 1.4 & 4.9 & -- & -- & -- & -- & -- & -- & -- & -- & -- & 4.2 & 1.5 & 35.0 \\
\hline 1973 & 57.1 & 16.3 & 28.6 & 96.7 & 19.9 & 20.6 & -- & -- & -- & -- & -- & -- & -- & -- & -- & 24.0 & 2.7 & 11.0 \\
\hline 1974 & 38.5 & 9.1 & 23.5 & 71.1 & 13.6 & 19.2 & -- & -- & -- & -- & -- & -- & -- & -- & -- & 35.5 & 4.1 & 11.4 \\
\hline 1975 & 82.2 & 17.3 & 21.0 & 102.5 & 23.5 & 22.9 & -- & -- & -- & -- & -- & -- & -- & -- & -- & 18.5 & 7.0 & 37.8 \\
\hline 1976 & 17.5 & 10.1 & 58.0 & 39.7 & 12.1 & 30.4 & -- & -- & -- & -- & -- & -- & -- & -- & -- & 18.9 & 7.2 & 38.0 \\
\hline 1977 & 98.3 & 13.9 & 14.2 & 134.5 & 11.0 & 8.2 & -- & -- & -- & -- & -- & -- & -- & -- & -- & 11.4 & 6.1 & 53.8 \\
\hline 1978 & 51.3 & 12.1 & 23.7 & 133.3 & 10.7 & 8.0 & -- & -- & -- & -- & -- & -- & -- & -- & -- & 24.5 & 6.8 & 27.8 \\
\hline 1979 & 55.7 & 14.6 & 26.3 & 45.2 & 12.3 & 27.2 & -- & -- & -- & -- & -- & -- & -- & -- & -- & 12.8 & 6.6 & 51.3 \\
\hline 1980 & 53.6 & 11.2 & 21.0 & 69.6 & 7.8 & 11.3 & -- & -- & -- & -- & -- & -- & 281.0 & 51.1 & 18.2 & 12.4 & 4.7 & 37.7 \\
\hline 1981 & 32.9 & 8.4 & 25.5 & 27.2 & 5.8 & 21.4 & -- & -- & -- & -- & -- & -- & 78.6 & 11.1 & 14.1 & 13.0 & 4.3 & 33.0 \\
\hline 1982 & 49.8 & 8.1 & 16.2 & 88.3 & 18.5 & 20.9 & -- & -- & -- & -- & -- & -- & 138.5 & 19.3 & 14.0 & 7.2 & 4.3 & 59.7 \\
\hline 1983 & 26.5 & 8.5 & 31.9 & 60.6 & 15.1 & 24.8 & -- & -- & -- & -- & -- & -- & 210.8 & 32.5 & 15.4 & 38.6 & 4.8 & 12.3 \\
\hline 1984 & 18.1 & 6.5 & 35.7 & 21.1 & 6.8 & 32.2 & -- & -- & -- & -- & -- & -- & 53.6 & 17.2 & 32.2 & 7.5 & 4.6 & 60.9 \\
\hline 1985 & 44.3 & 10.0 & 22.5 & 81.4 & 14.8 & 18.1 & -- & -- & -- & -- & -- & -- & 205.7 & 35.1 & 17.1 & 15.3 & 4.7 & 30.7 \\
\hline 1986 & 87.0 & 19.3 & 22.1 & 182.6 & 45.6 & 25.0 & -- & -- & -- & -- & -- & -- & 424.2 & 150.8 & 35.5 & 25.7 & 6.8 & 26.5 \\
\hline 1987 & 54.4 & 19.1 & 35.1 & 101.5 & 65.1 & 64.2 & -- & -- & -- & -- & -- & -- & 394.2 & 167.8 & 42.6 & 24.4 & 10.2 & 41.5 \\
\hline
\end{tabular}


Table 4. Annual mean streamflow, base flow, and base-flow index values for selected U.S. Geological Survey streamgages in and near the Salt Fork Red River aquifer study area, 1980-2017.-Continued

[ft3/s, cubic foot per second; \%, percent; BFI, base-flow index; --, data not available; acre-ft/yr, acre-foot per year. Values computed by using the BFI code (Wahl and Wahl, 1995) in the U.S. Geological Survey Groundwater Toolbox (Barlow and others, 2015). Streamgage locations are shown on figure 2, and streamgage information is listed in table 1]

\begin{tabular}{|c|c|c|c|c|c|c|c|c|c|c|c|c|c|c|c|c|c|c|}
\hline \multirow{3}{*}{ Year } & \multicolumn{3}{|c|}{$\begin{array}{c}07300000 \text { Salt Fork Red } \\
\text { River near Wellington, } \\
\text { Tex. }\end{array}$} & \multicolumn{3}{|c|}{$\begin{array}{l}07300500 \text { Salt Fork Red } \\
\text { River at Mangum, Okla. }\end{array}$} & \multicolumn{3}{|c|}{$\begin{array}{c}07300530 \text { Bitter Creek } \\
\text { near Martha, Okla. }\end{array}$} & \multicolumn{3}{|c|}{$\begin{array}{c}07300580 \text { Bitter Creek } \\
\text { west of Altus, Okla. }\end{array}$} & \multicolumn{3}{|c|}{$\begin{array}{l}07301110 \text { Salt Fork Red } \\
\text { River near Elmer, Okla. }\end{array}$} & \multicolumn{3}{|c|}{$\begin{array}{c}07299670 \text { Groesbeck } \\
\text { Creek at State Highway } \\
6 \text { near Quanah, Tex. }\end{array}$} \\
\hline & \multirow{2}{*}{$\begin{array}{l}\text { Mean } \\
\text { streamflow, } \\
\text { in } \mathrm{ft}^{3} / \mathrm{s}\end{array}$} & \multicolumn{2}{|c|}{$\begin{array}{l}\text { Mean base } \\
\text { flow }\end{array}$} & \multirow{2}{*}{$\begin{array}{c}\text { Mean } \\
\text { stream- } \\
\text { flow, in } \\
\mathrm{ft}^{3} / \mathrm{s}\end{array}$} & \multicolumn{2}{|c|}{$\begin{array}{l}\text { Mean base } \\
\text { flow }\end{array}$} & \multirow{2}{*}{$\begin{array}{c}\text { Mean } \\
\text { stream- } \\
\text { flow, in } \\
\mathrm{ft}^{3} / \mathrm{s}\end{array}$} & \multicolumn{2}{|c|}{$\begin{array}{l}\text { Mean base } \\
\text { flow }\end{array}$} & \multirow{2}{*}{$\begin{array}{c}\text { Mean } \\
\text { stream- } \\
\text { flow, in } \\
\mathrm{ft}^{3} / \mathrm{s}\end{array}$} & \multicolumn{2}{|c|}{$\begin{array}{l}\text { Mean base } \\
\text { flow }\end{array}$} & \multirow{2}{*}{$\begin{array}{c}\text { Mean } \\
\text { stream- } \\
\text { flow, in } \\
\mathrm{ft}^{3} / \mathrm{s}\end{array}$} & \multicolumn{2}{|c|}{$\begin{array}{c}\text { Mean base } \\
\text { flow }\end{array}$} & \multirow{2}{*}{$\begin{array}{c}\text { Mean } \\
\text { stream- } \\
\text { flow, in } \\
\mathrm{ft} 3 / \mathrm{s}\end{array}$} & \multicolumn{2}{|c|}{$\begin{array}{c}\text { Mean base } \\
\text { flow }\end{array}$} \\
\hline & & $\mathrm{ft}^{3} / \mathrm{s}$ & $\begin{array}{c}\% \\
\text { (BFI) }\end{array}$ & & $\mathrm{ft}^{3} / \mathrm{s}$ & $\%$ (BFI) & & $\mathrm{ft}^{3} / \mathrm{s}$ & $\begin{array}{c}\% \\
\text { (BFI) }\end{array}$ & & $\mathrm{ft}^{3} / \mathrm{s}$ & $\begin{array}{c}\% \\
\text { (BFI) }\end{array}$ & & $\mathrm{ft}^{3} / \mathrm{s}$ & $\begin{array}{c}\% \\
\text { (BFI) }\end{array}$ & & $\mathrm{ft}^{3} / \mathrm{s}$ & $\begin{array}{c}\% \\
\text { (BFI) }\end{array}$ \\
\hline 1988 & 30.0 & 15.4 & 51.3 & 48.6 & 31.3 & 64.4 & -- & -- & -- & -- & -- & -- & 179.4 & 104.8 & 58.4 & 26.0 & 10.8 & 41.3 \\
\hline 1989 & 114.9 & 13.8 & 12.1 & 80.5 & 21.4 & 26.6 & -- & -- & -- & -- & -- & -- & 237.1 & 49.2 & 20.7 & 25.0 & 9.7 & 38.9 \\
\hline 1990 & 55.9 & 16.3 & 29.1 & 73.0 & 28.9 & 39.6 & -- & -- & -- & -- & -- & -- & 251.6 & 80.3 & 31.9 & 17.8 & 10.5 & 58.7 \\
\hline 1991 & 52.9 & 16.0 & 30.2 & 77.9 & 26.9 & 34.6 & -- & -- & -- & -- & -- & -- & 416.0 & 67.3 & 16.2 & 69.9 & 13.6 & 19.4 \\
\hline 1992 & 61.2 & 21.1 & 34.4 & 90.7 & 40.4 & 44.5 & -- & -- & -- & -- & -- & -- & 313.3 & 93.1 & 29.7 & 24.6 & 19.6 & 79.5 \\
\hline 1993 & 48.2 & 17.3 & 35.8 & 125.2 & 48.9 & 39.0 & -- & -- & -- & -- & -- & -- & 355.8 & 125.1 & 35.2 & 26.6 & 19.1 & 71.5 \\
\hline 1994 & 19.3 & 14.2 & 73.2 & 34.2 & 18.0 & 52.4 & -- & -- & -- & -- & -- & -- & 113.3 & 43.4 & 38.3 & 22.3 & 14.0 & 62.8 \\
\hline 1995 & 119.6 & 15.6 & 13.0 & 207.1 & 54.1 & 26.1 & -- & -- & -- & -- & -- & -- & 536.2 & 110.9 & 20.7 & 112.3 & 18.1 & 16.1 \\
\hline 1996 & 46.8 & 17.3 & 37.0 & 84.5 & 50.8 & 60.2 & -- & -- & -- & -- & -- & -- & 287.9 & 96.6 & 33.6 & 58.0 & 21.4 & 36.8 \\
\hline 1997 & 170.7 & 33.5 & 19.6 & 261.8 & 89.5 & 34.2 & -- & -- & -- & -- & -- & -- & 610.1 & 208.4 & 34.2 & 58.0 & 30.1 & 51.9 \\
\hline 1998 & 50.6 & 25.9 & 51.3 & 97.5 & 64.4 & 66.0 & -- & -- & -- & -- & -- & -- & 236.6 & 142.6 & 60.3 & 30.8 & 24.4 & 79.0 \\
\hline 1999 & 37.1 & 11.5 & 30.8 & 61.4 & 23.6 & 38.5 & 19.5 & 5.8 & 29.6 & 35.6 & 8.1 & 22.8 & 171.0 & 58.9 & 34.4 & 31.6 & 17.9 & 56.8 \\
\hline 2000 & 43.4 & 14.3 & 33.0 & 58.1 & 27.3 & 47.0 & 17.9 & 6.2 & 34.6 & 29.1 & 9.8 & 33.7 & 133.9 & 44.4 & 33.2 & 32.0 & 18.2 & 57.0 \\
\hline 2001 & 46.4 & 15.2 & 32.8 & 49.4 & 25.6 & 51.7 & 16.8 & 6.2 & 37.1 & 27.0 & 11.1 & 41.3 & 124.3 & 64.9 & 52.2 & 27.0 & 18.2 & 67.5 \\
\hline 2002 & 42.1 & 16.9 & 40.0 & 37.5 & 13.9 & 37.1 & 11.1 & 3.8 & 34.2 & 16.7 & 7.1 & 42.4 & 68.8 & 32.6 & 47.4 & 12.2 & 7.5 & 61.3 \\
\hline 2003 & 33.2 & 12.8 & 38.6 & 30.3 & 11.4 & 37.6 & 5.6 & 2.3 & 40.9 & 11.5 & 3.9 & 33.9 & 57.3 & 23.4 & 40.8 & 17.4 & 11.6 & 66.7 \\
\hline 2004 & 41.1 & 20.0 & 48.6 & 48.8 & 24.1 & 49.5 & 15.7 & 2.8 & 17.6 & 26.8 & 5.3 & 20.0 & 134.1 & 36.6 & 27.3 & 19.7 & 10.3 & 52.1 \\
\hline 2005 & 27.4 & 15.8 & 57.7 & 27.1 & 16.4 & 60.4 & -- & -- & -- & -- & -- & -- & 95.3 & 45.7 & 47.9 & 16.7 & 9.6 & 57.4 \\
\hline 2006 & 20.5 & 7.8 & 38.1 & 20.5 & 4.7 & 23.2 & -- & -- & -- & -- & -- & -- & 45.4 & 12.9 & 28.4 & 37.5 & 7.7 & 20.6 \\
\hline 2007 & 47.7 & 19.6 & 41.0 & 67.9 & 27.3 & 40.2 & -- & -- & -- & -- & -- & -- & 142.7 & 71.8 & 50.3 & 22.5 & 10.4 & 46.1 \\
\hline 2008 & 23.5 & 10.0 & 42.5 & 33.7 & 13.6 & 40.2 & -- & -- & -- & -- & -- & -- & 73.8 & 34.9 & 47.4 & 23.1 & 12.5 & 54.0 \\
\hline 2009 & 15.3 & 10.6 & 69.2 & 18.1 & 11.2 & 61.5 & -- & -- & -- & -- & -- & -- & 70.0 & 32.0 & 45.8 & 28.7 & 9.4 & 32.9 \\
\hline 2010 & 53.6 & 13.6 & 25.3 & 61.5 & 14.9 & 24.3 & -- & -- & -- & -- & -- & -- & 160.0 & 49.2 & 30.8 & 28.1 & 11.7 & 41.7 \\
\hline 2011 & 9.6 & 6.7 & 69.7 & 7.4 & 5.0 & 67.9 & -- & -- & -- & -- & -- & -- & 32.9 & 14.0 & 42.5 & 11.5 & 8.4 & 72.6 \\
\hline 2012 & 11.5 & 4.3 & 37.3 & 7.6 & 1.8 & 23.4 & -- & -- & -- & -- & -- & -- & 22.7 & 6.7 & 29.7 & 22.2 & 6.1 & 27.7 \\
\hline
\end{tabular}


Table 4. Annual mean streamflow, base flow, and base-flow index values for selected U.S. Geological Survey streamgages in and near the Salt Fork Red River aquifer study area, 1980-2017.-Continued

[ft3/s, cubic foot per second; \%, percent; BFI, base-flow index; --, data not available; acre-ft/yr, acre-foot per year. Values computed by using the BFI code (Wahl and Wahl, 1995) in the U.S. Geological Survey Groundwater Toolbox (Barlow and others, 2015). Streamgage locations are shown on figure 2, and streamgage information is listed in table 1]

\begin{tabular}{|c|c|c|c|c|c|c|c|c|c|c|c|c|c|c|c|c|c|c|}
\hline \multirow{3}{*}{ Year } & \multicolumn{3}{|c|}{$\begin{array}{c}07300000 \text { Salt Fork Red } \\
\text { River near Wellington, } \\
\text { Tex. }\end{array}$} & \multicolumn{3}{|c|}{$\begin{array}{l}07300500 \text { Salt Fork Red } \\
\text { River at Mangum, Okla. }\end{array}$} & \multicolumn{3}{|c|}{$\begin{array}{c}07300530 \text { Bitter Creek } \\
\text { near Martha, Okla. }\end{array}$} & \multicolumn{3}{|c|}{$\begin{array}{c}07300580 \text { Bitter Creek } \\
\text { west of Altus, Okla. }\end{array}$} & \multicolumn{3}{|c|}{$\begin{array}{l}07301110 \text { Salt Fork Red } \\
\text { River near Elmer, Okla. }\end{array}$} & \multicolumn{3}{|c|}{$\begin{array}{c}07299670 \text { Groesbeck } \\
\text { Creek at State Highway } \\
6 \text { near Quanah, Tex. }\end{array}$} \\
\hline & \multirow{2}{*}{$\begin{array}{l}\text { Mean } \\
\text { streamflow, } \\
\text { in } \mathrm{ft}^{3} / \mathrm{s}\end{array}$} & \multicolumn{2}{|c|}{$\begin{array}{c}\text { Mean base } \\
\text { flow }\end{array}$} & \multirow{2}{*}{$\begin{array}{c}\text { Mean } \\
\text { stream- } \\
\text { flow, in } \\
\mathrm{ft} 3 / \mathrm{s}\end{array}$} & \multicolumn{2}{|c|}{$\begin{array}{c}\text { Mean base } \\
\text { flow }\end{array}$} & \multirow{2}{*}{$\begin{array}{c}\text { Mean } \\
\text { stream- } \\
\text { flow, in } \\
\mathrm{ft} 3 / \mathrm{s}\end{array}$} & \multicolumn{2}{|c|}{$\begin{array}{c}\text { Mean base } \\
\text { flow }\end{array}$} & \multirow{2}{*}{$\begin{array}{c}\text { Mean } \\
\text { stream- } \\
\text { flow, in } \\
\mathrm{ft}^{3} / \mathrm{s}\end{array}$} & \multicolumn{2}{|c|}{$\begin{array}{c}\text { Mean base } \\
\text { flow }\end{array}$} & \multirow{2}{*}{$\begin{array}{c}\text { Mean } \\
\text { stream- } \\
\text { flow, in } \\
\mathrm{ft}^{3} / \mathrm{s}\end{array}$} & \multicolumn{2}{|c|}{$\begin{array}{c}\text { Mean base } \\
\text { flow }\end{array}$} & \multirow{2}{*}{$\begin{array}{c}\text { Mean } \\
\text { stream- } \\
\text { flow, in } \\
\mathrm{ft}^{3} / \mathrm{s}\end{array}$} & \multicolumn{2}{|c|}{$\begin{array}{c}\text { Mean base } \\
\text { flow }\end{array}$} \\
\hline & & $\mathrm{ft}^{3} / \mathrm{s}$ & $\begin{array}{c}\% \\
\text { (BFI) }\end{array}$ & & $\mathrm{ft}^{3} / \mathrm{s}$ & $\%$ (BFI) & & $\mathrm{ft}^{3} / \mathrm{s}$ & $\begin{array}{c}\% \\
\text { (BFI) }\end{array}$ & & $\mathrm{ft}^{3} / \mathrm{s}$ & $\begin{array}{c}\% \\
\text { (BFI) }\end{array}$ & & $\mathrm{ft}^{3} / \mathrm{s}$ & $\begin{array}{c}\% \\
\text { (BFI) }\end{array}$ & & $\mathrm{ft}^{3} / \mathrm{s}$ & $\begin{array}{c}\% \\
\text { (BFI) }\end{array}$ \\
\hline 2013 & 9.3 & 4.1 & 44.3 & 3.1 & 0.6 & 17.5 & -- & -- & -- & -- & -- & -- & 3.4 & 1.4 & 40.5 & 7.2 & 5.8 & 80.0 \\
\hline 2014 & 8.9 & 4.5 & 50.2 & 2.8 & 0.3 & 11.4 & -- & -- & -- & -- & -- & -- & 27.9 & 1.9 & 6.6 & 23.5 & 5.6 & 23.7 \\
\hline 2015 & 56.0 & 18.7 & 33.3 & 145.0 & 34.4 & 23.7 & -- & -- & -- & -- & -- & -- & 349.1 & 107.7 & 30.9 & 44.2 & 5.8 & 13.0 \\
\hline 2016 & 24.8 & 15.7 & 63.1 & 46.5 & 33.3 & 71.7 & -- & -- & -- & -- & -- & -- & 217.9 & 127.0 & 58.3 & 29.5 & 9.2 & 31.1 \\
\hline 2017 & 22.4 & 13.8 & 61.8 & 56.8 & 25.0 & 44.0 & -- & -- & -- & -- & -- & -- & 147.6 & 81.6 & 55.3 & 18.7 & 11.0 & 58.6 \\
\hline 1980-2015 & 46.2 & 14.0 & 36.9 & 69.3 & 25.3 & 37.8 & 14.4 & 4.5 & 32.3 & 24.5 & 7.6 & 32.4 & 195.5 & 62.4 & 33.5 & 28.3 & 11.4 & 46.9 \\
\hline $\begin{array}{l}\text { 1980-2015, in } \\
\text { thousands of } \\
\text { acre-ft/yr }\end{array}$ & 33.5 & 10.1 & -- & 50.2 & 18.3 & -- & 10.5 & 3.3 & -- & 17.7 & 5.5 & -- & 141.6 & 45.2 & -- & 20.5 & 8.3 & -- \\
\hline $\begin{array}{l}\text { Mean base- } \\
\text { flow gain, } \\
\text { in acre-ft/yr, } \\
\text { upgradient } \\
\text { from Mangum } \\
\text { streamgage }\end{array}$ & 8,181 & & & & & & & & & & & & & & & & & \\
\hline $\begin{array}{l}\text { Mean base- } \\
\text { flow gain, } \\
\text { in acre-ft/yr, } \\
\text { downgradient } \\
\text { from Mangum } \\
\text { streamgage }\end{array}$ & 15,320 & & & & & & & & & & & & & & & & & \\
\hline
\end{tabular}




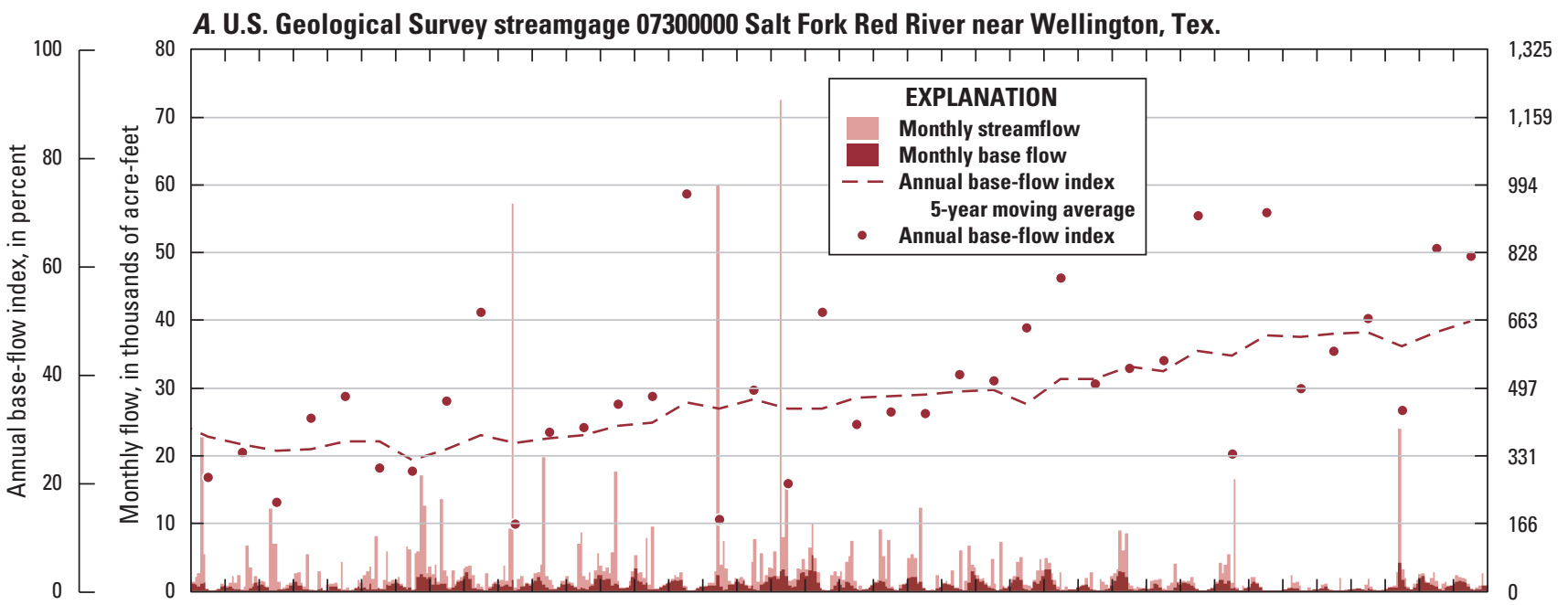

B. U.S. Geological Survey streamgage 07300500 Salt Fork Red River at Mangum, Okla.

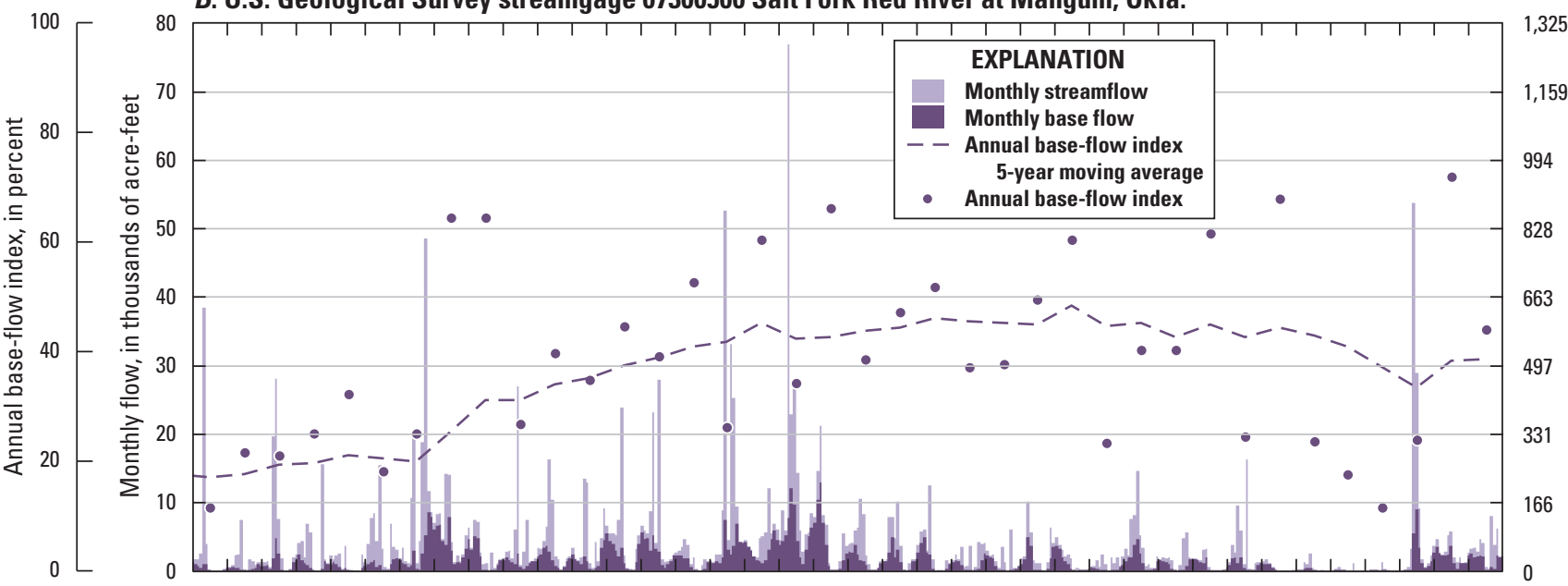

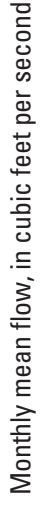

C. U.S. Geological Survey streamgage 07301110 Salt Fork Red River near Elmer, Okla.

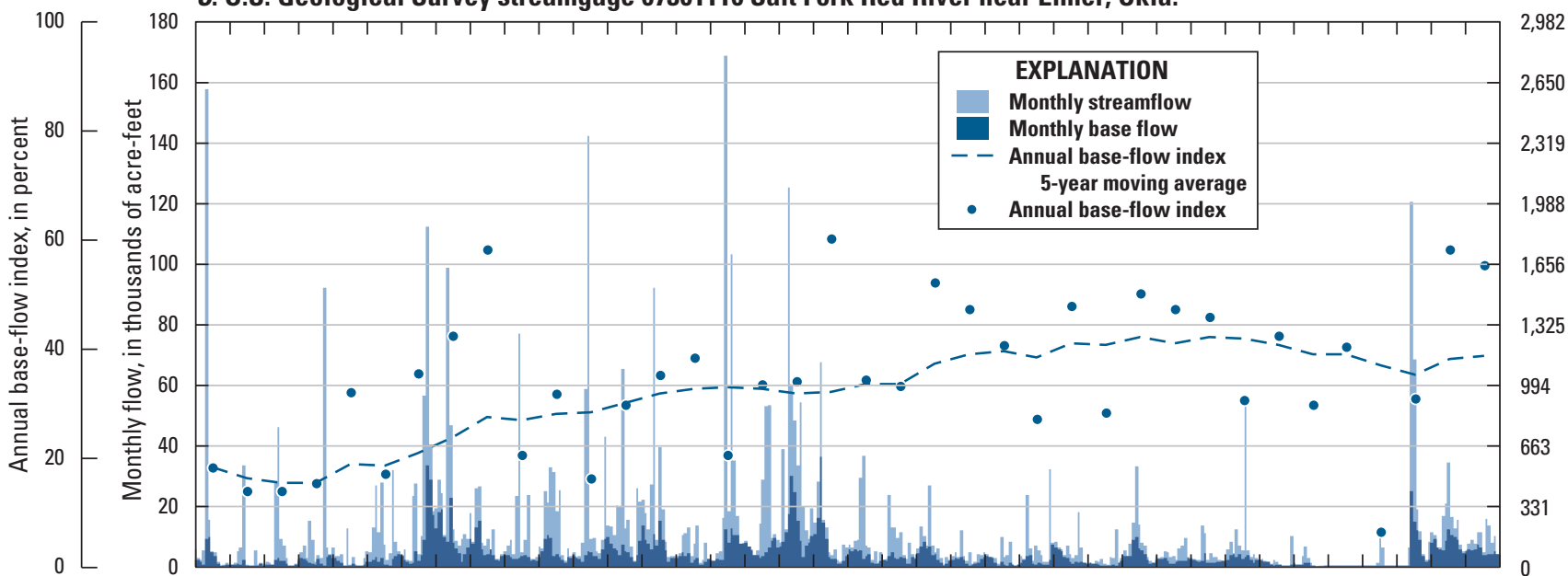

2,982

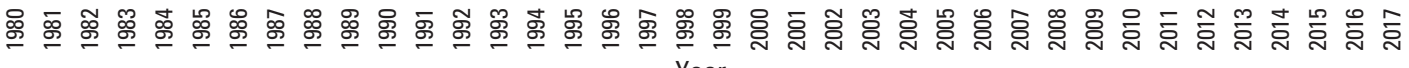

Figure 8. Monthly streamflow, monthly base flow, and annual base-flow index values for U.S. Geological Survey streamgages $A$, 07300000 Salt Fork Red River near Wellington, Tex.; B, 07300500 Salt Fork Red River at Mangum, Okla.; and C, 07301110 Salt Fork Red River near Elmer, Okla., 1980-2017. 


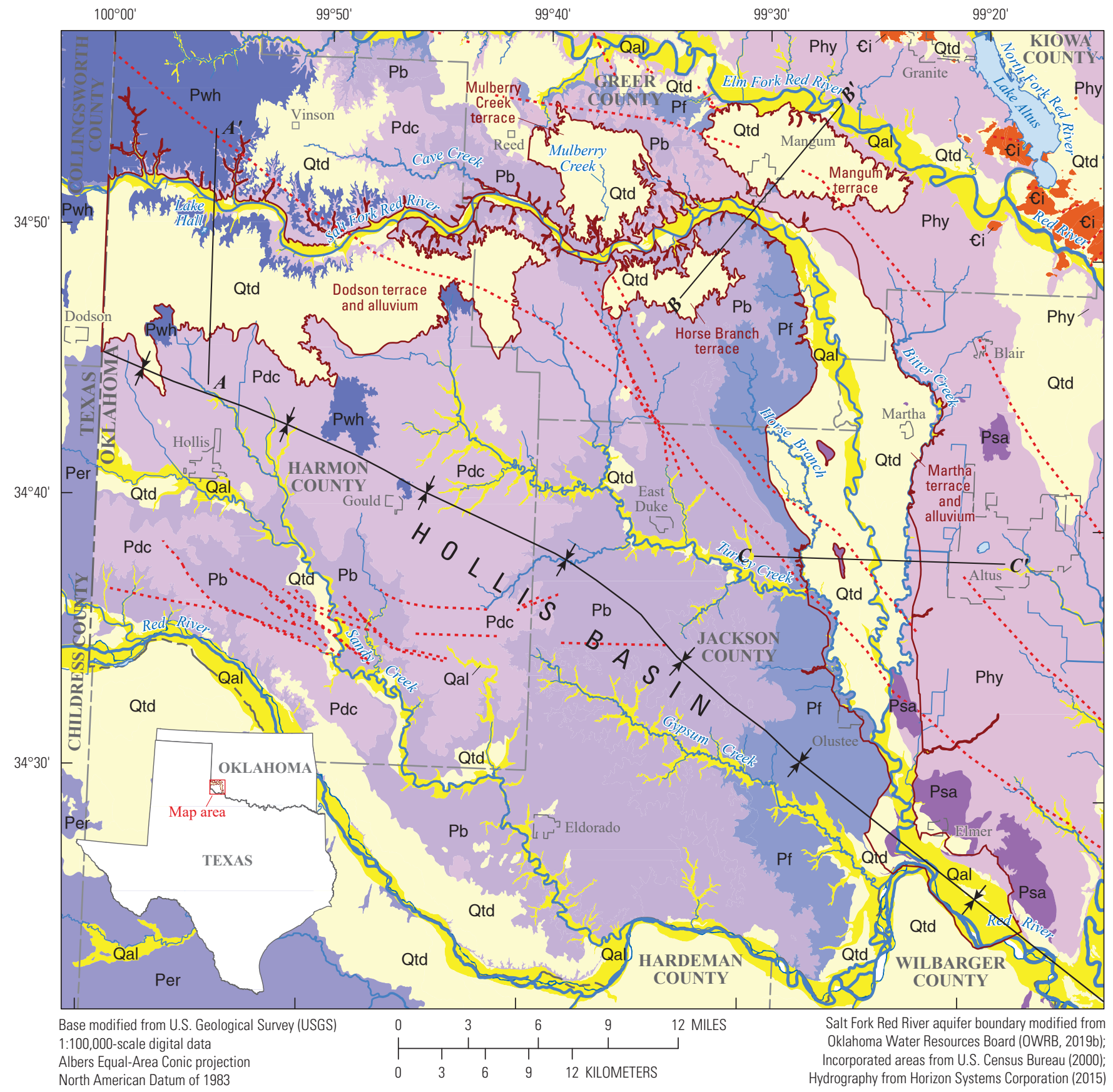

EXPLANATION

Surficial geologic unit (Stanley, 2004; Stanley and Miller, 2004; Stoeser and others, 2005) Quaternary

\begin{tabular}{|c|c|c|c|}
\hline Qal & Active alluvium & $\mathrm{Pf}$ & Flower-pot Shale \\
\hline \multirow[t]{2}{*}{ Qtd } & Terrace, including dunes & Psa & Duncan Sandstone \\
\hline & Permian & Per & El Reno Group, undivided \\
\hline Pwh & Whitehorse Group & Phy & Hennessey Group \\
\hline Pdc & Dog Creek Shale & & Cambrian \\
\hline $\mathrm{Pb}$ & Blaine Formation & $€ \mathrm{i}$ & Wichita Granite Group \\
\hline
\end{tabular}

\section{Salt Fork Red River aquifer boundary}

$A-A^{\prime} \quad$ Line of section (fig. 11)

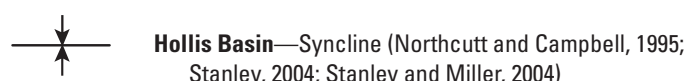
Stanley, 2004; Stanley and Miller, 2004)

Fault-Concealed (Stanley, 2004; Stanley and Miller, 2004; Marsh and Holland, 2016

Figure 9. Surficial geologic units and major structural features of the Salt Fork Red River aquifer study area, southwestern Oklahoma. 


\begin{tabular}{|c|c|c|c|c|c|}
\hline System & \multicolumn{2}{|c|}{ Geologic unit } & $\begin{array}{l}\text { Hydrogeologic } \\
\text { unit }\end{array}$ & $\begin{array}{c}\text { Thickness, } \\
\text { in feet }\end{array}$ & Description \\
\hline Quaternary & \multicolumn{2}{|c|}{$\begin{array}{l}\text { Alluvium (Qal) and terrace } \\
\text { deposits (Qtd) including } \\
\text { dunes and colluvium }\end{array}$} & $\begin{array}{l}\text { Salt Fork Red } \\
\text { River aquifer, } \\
\text { North Fork Red } \\
\text { River aquifer, } \\
\text { and Red River } \\
\text { aquifer }\end{array}$ & $0-240$ & $\begin{array}{l}\text { Silt, sand, and clay deposited by the major streams of } \\
\text { the study area; often reworked by wind; occasionally } \\
\text { containing quartzitic gravel }\end{array}$ \\
\hline \multirow{7}{*}{ Permian } & \multirow{2}{*}{ 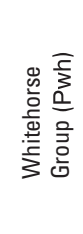 } & $\begin{array}{l}\text { Rush Springs } \\
\text { Formation }\end{array}$ & $\begin{array}{l}\text { Western } \\
\text { Oklahoma } \\
\text { minor aquifer } \\
\text { (OWRB, 2019b) }\end{array}$ & \multirow[t]{2}{*}{$0-100$} & $\begin{array}{l}\text { Red to pink, massive, fine-grained, gypsiferous } \\
\text { sandstone }\end{array}$ \\
\hline & & $\begin{array}{l}\text { Marlow } \\
\text { Formation }\end{array}$ & -- & & $\begin{array}{l}\text { Orange-brown, fine-grained sandstone and siltstone } \\
\text { with some dolomite and gypsum }\end{array}$ \\
\hline & \multirow{4}{*}{ 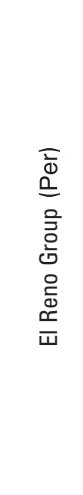 } & $\begin{array}{l}\text { Dog Creek } \\
\text { Shale (Pdc) }\end{array}$ & -- & $0-200$ & $\begin{array}{l}\text { Red, brown, and green gypsiferous shales with several } \\
\text { beds of siltstone, fine-grained sandstone, and dolomite }\end{array}$ \\
\hline & & $\begin{array}{l}\text { Blaine Formation } \\
\text { (Pb) including } \\
\text { Van Vacter } \\
\text { Gypsum Member }\end{array}$ & $\begin{array}{l}\text { Blaine } \\
\text { aquifer }\end{array}$ & $0-180$ & $\begin{array}{l}\text { Beds of white massive gypsum and thin beds of gray } \\
\text { medium-grained dolomite or dolomitic limestone } \\
\text { separated by well-defined units of red and green shale. } \\
\text { Forms an aquifer where dissolution has created caverns }\end{array}$ \\
\hline & & $\begin{array}{l}\text { Flower-pot } \\
\text { Shale (Pf) }\end{array}$ & -- & $0-160$ & $\begin{array}{l}\text { Red, brown, and maroon blocky shales with green and } \\
\text { gray shales and thin beds of gypsum and dolomite }\end{array}$ \\
\hline & & $\begin{array}{c}\text { Duncan } \\
\text { Sandstone (Psa) }\end{array}$ & -- & $0-100$ & $\begin{array}{l}\text { Grayish-brown to buff, indurated, highly cross-bedded, } \\
\text { ripple-marked, nonfossiliferous, silty to very-fine-grained } \\
\text { dolomitic sandstone with interbedded shale }\end{array}$ \\
\hline & \multicolumn{2}{|c|}{ Hennessey Group (Phy) } & -- & $0-500$ & $\begin{array}{l}\text { Yellowish gray to buff unfossiliferous shale with } \\
\text { calcareous fine-grained siltstone }\end{array}$ \\
\hline Cambrian & \multicolumn{2}{|c|}{ Wichita Granite Group (€i) } & -- & Unknown & Igneous rocks of Wichita Uplift \\
\hline
\end{tabular}

OWRB, Oklahoma Water Resources Board ,-- Not applicable

Modified from Stanley (2004); Stanley and Miller (2004); Smith and others (2017a)

Figure 10. Surficial geologic and hydrogeologic units of the Salt Fork Red River aquifer study area, southwestern Oklahoma. 
A. Dodson terrace of the Salt Fork Red River aquifer

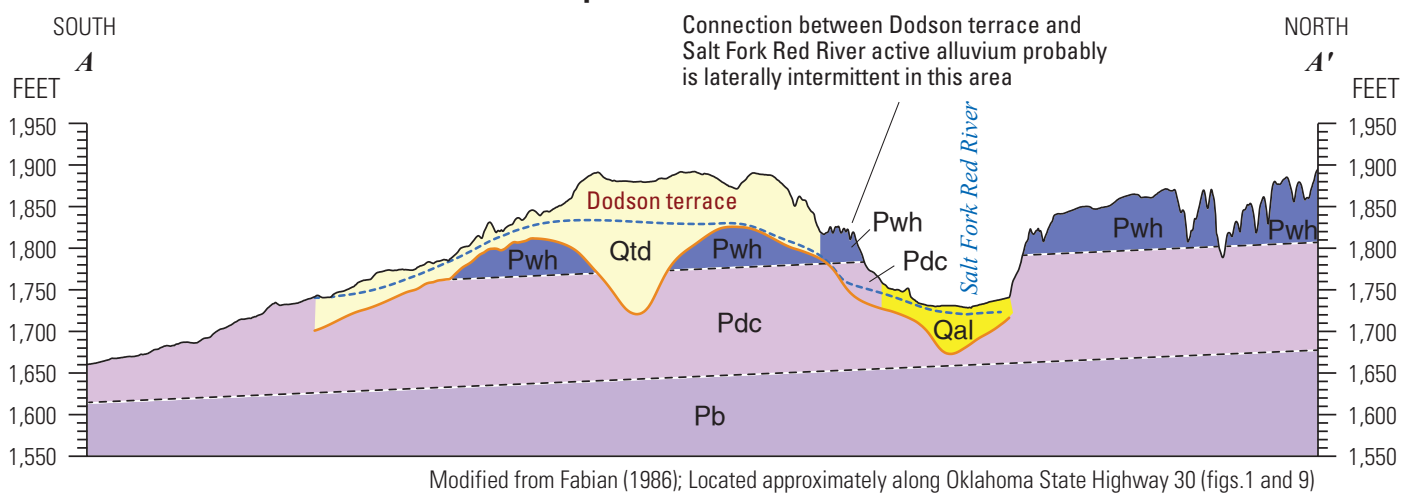

\section{B. Mangum terrace of the Salt Fork Red River aquifer}

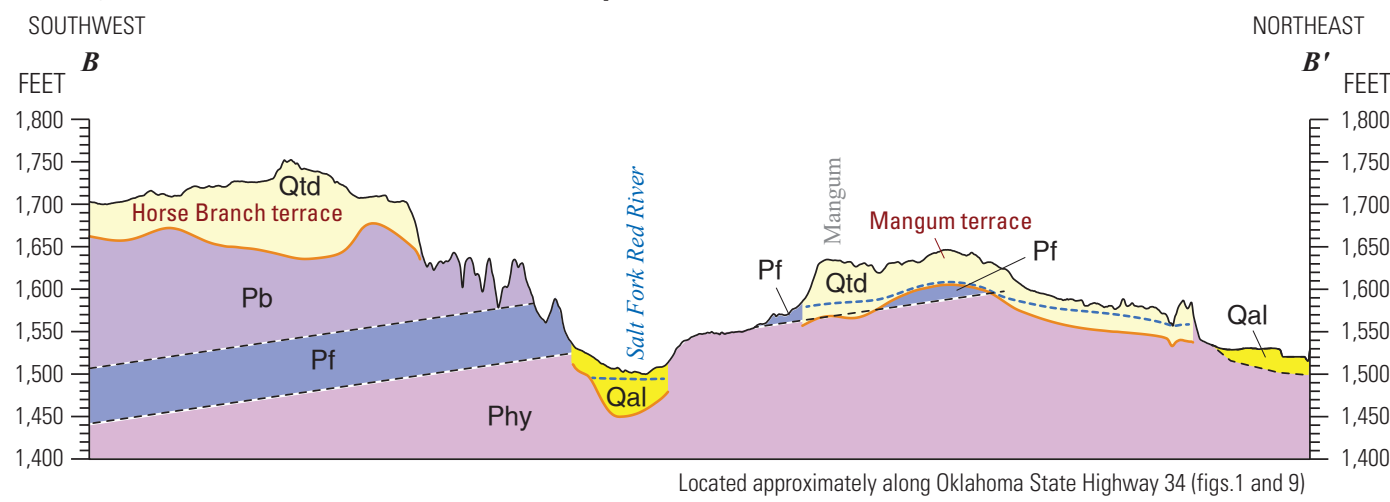

\section{Martha terrace of the Salt Fork Red River aquifer}
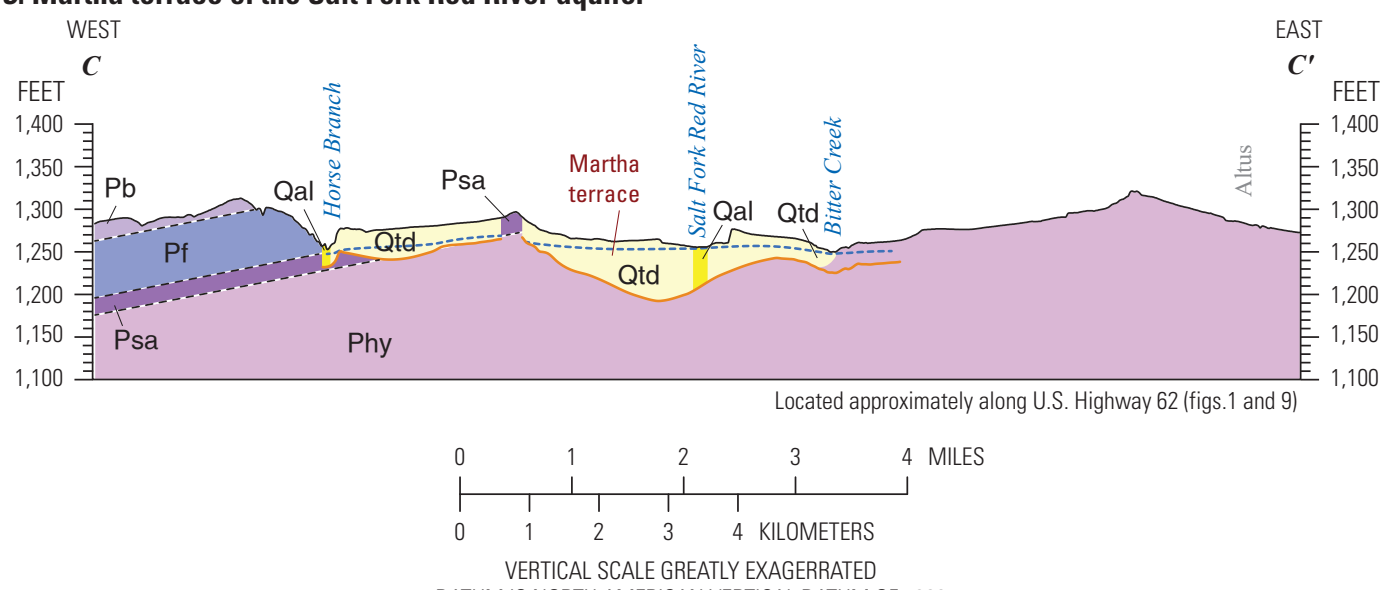

DATUM IS NORTH AMERICAN VERTICAL DATUM OF 1988

\section{EXPLANATION}

Geologic unit (Stanley, 2004; Stanley and Miller, 2004; Stoeser and others, 2005) Quaternary

$\begin{array}{ll}\text { Qal Active alluvium } \\ \text { Qtd } & \text { Terrace, including dunes }\end{array}$

\section{Permian}

\section{Pwh}

Pdc
Whitehorse Group Dog Creek Shale

Blaine Formation

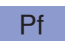

Psa

Phy
Flower-pot Shale

Duncan Sandstone

Hennessey Group

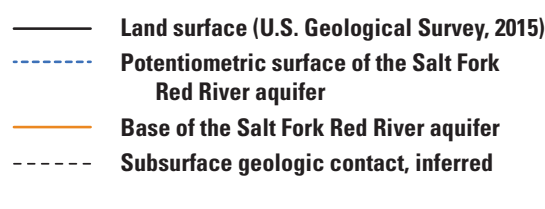

Note: Faults are present at depth in the bedrock of pre-Permian age in the study area (fig. 9; Stanley, 2004; Stanley and Miller, 2004; Marsh and Holland, 2016), but they are unlikely to continue into the alluvium and terrace deposits or affect groundwater flow in the Salt Fork Red River aquifer.

Figure 11. Hydrogeologic cross sections that include $A$, the Dodson terrace; $B$, the Mangum terrace; and $C$, the Martha terrace of the Salt Fork Red River aquifer, southwestern Oklahoma. 


\section{Groundwater Quality}

Groundwater quality in the study area varies greatly and depends on the properties of the geologic unit in which the water is found. Major-ion concentrations measured in groundwater samples collected from wells completed in the Salt Fork Red River aquifer, especially the Dodson terrace, generally were smaller than the major-ion concentrations measured in groundwater samples collected from wells completed in the surrounding bedrock of Permian age (fig. 12). Groundwater in the Permian-age bedrock units reflects dissolution of calcium sulfate (gypsum) and sodium chloride (halite) because of the abundance of evaporite deposits in those units. Water in the Permian-age bedrock commonly has dissolved calcium and sulfate concentrations exceeding 20 milliequivalents per liter (400 and 960 milligrams per liter [mg/L], respectively). Permian-age bedrock units that contain sodium chloride deposits, such as the Flower-pot Shale and Van Vacter Gypsum Member of the Blaine Formation, also commonly contain groundwater with dissolved sodium and chloride concentrations exceeding 20 milliequivalents per liter (460 and $710 \mathrm{mg} / \mathrm{L}$, respectively). These constituents provide a measure of the degree to which groundwater in the Salt Fork Red River aquifer has been mixed with groundwater in the surrounding Permian-age bedrock units. According to available waterquality data (Smith, 1970; Texas Water Development Board, 2015; USGS, 2019), groundwater in the Dodson and Mangum terraces has lower major-ion concentrations than groundwater in the active alluvium and groundwater in the Martha terrace (fig. 12). The groundwater quality in some parts of the Salt Fork Red River aquifer limits groundwater use for some purposes; groundwater in the Dodson terrace (in terms of major-ion concentrations) is suitable for all uses, whereas groundwater in parts of the Martha terrace is suitable for only irrigation of salinity-tolerant crops or livestock use because it has concentrations of chloride and sulfate that greatly exceed the National Secondary Drinking Water Regulations (250 and $250 \mathrm{mg} / \mathrm{L}$, respectively; U.S. Environmental Protection Agency, 2017).

Groundwater quality strongly influences surface-water quality in the Salt Fork Red River. Water type in the Salt Fork Red River was relatively consistent between the Wellington, Mangum, and Elmer gages on the Salt Fork Red River; in terms of major-ion milliequivalent concentrations during the available periods of record, calcium and sulfate (derived from gypsum in bedrock units of the study area) were the dominant ions in surface water of the Salt Fork Red River (USGS, 2019). Sodium and chloride milliequivalent concentrations, however, were larger at the Elmer gage relative to the Wellington and Mangum gages, reflecting the increased sodium-chloride content of the Blaine Formation and Flowerpot Shale present along the downgradient reaches of the Salt Fork Red River. Total milliequivalent concentrations at all three streamgages on the Salt Fork Red River were greatest when measured streamflows were less than the mean annual streamflows for those respective streamgages. This difference in geochemical content of water probably reflects (1) the increased influence of salt springs from outside the aquifer area at low flows and (2) the dilution of these salt-spring discharges by less salty runoff water during high flows. 

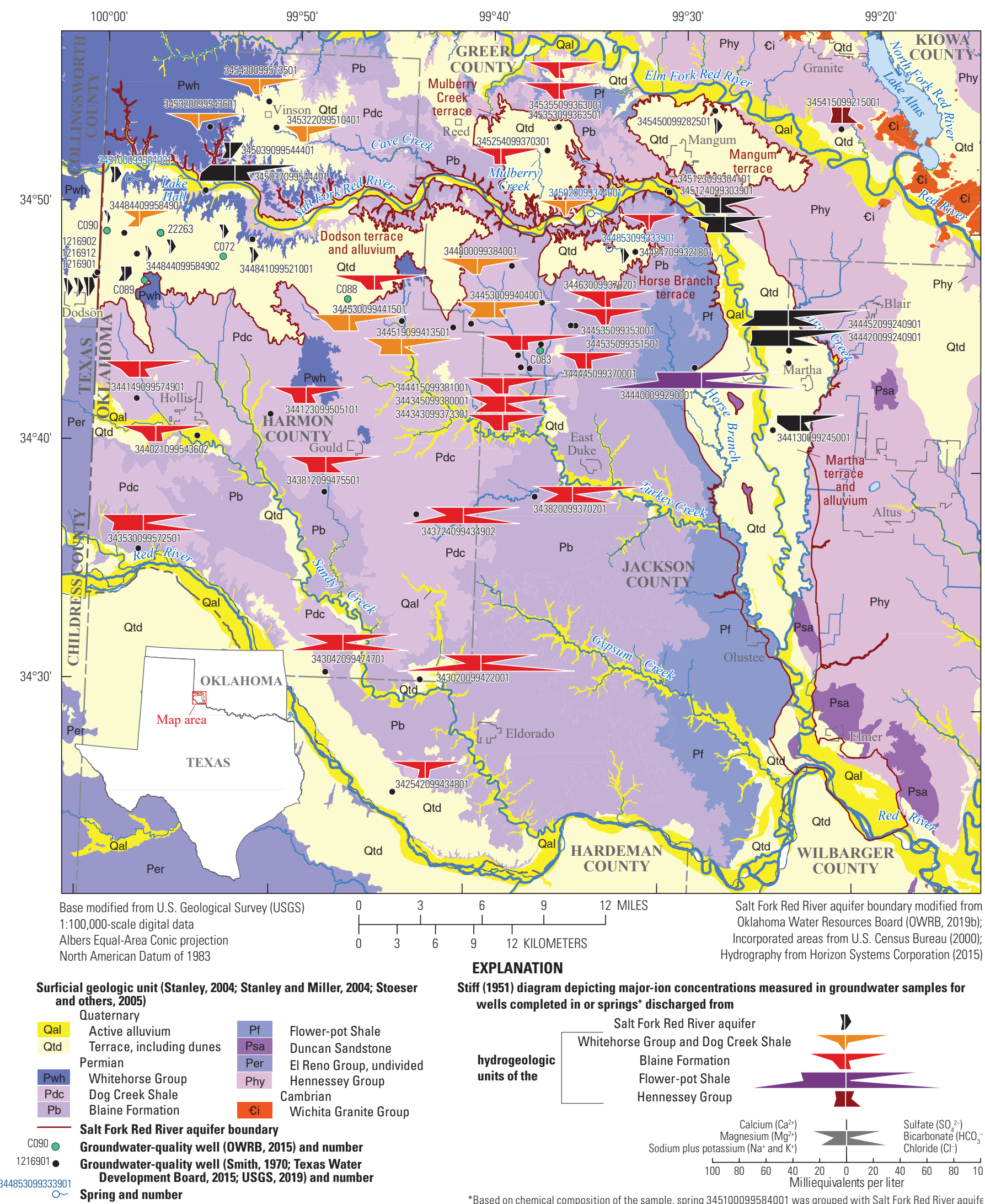

Stiff (1951) diagram depicting major-ion concentrations measured in groundwater samples for wells completed in or springs* discharged from

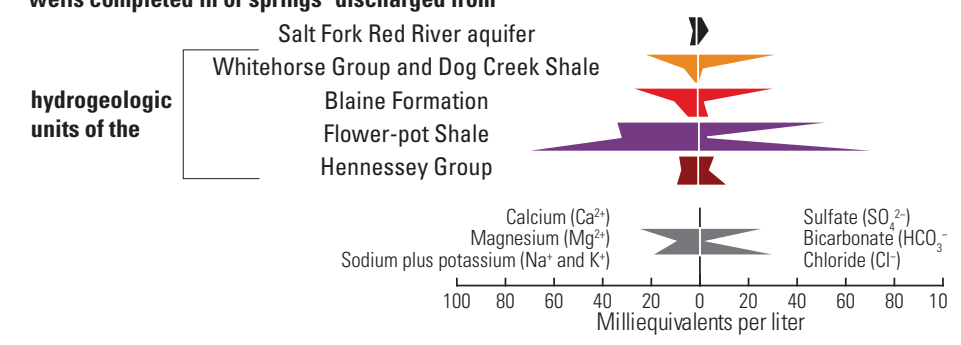

*Based on chemical composition of the sample, spring 345100099584001 was grouped with Salt Fork Red River aquife

Figure 12. Major-ion concentrations measured in groundwater samples from wells completed in different geologic and hydrogeologic units in and near the Salt Fork Red River aquifer, southwestern Oklahoma. 


\section{Hydrogeologic Framework}

A hydrogeologic framework is a three-dimensional representation of an aquifer and how it interfaces with surrounding geologic units at a scale that captures the regional controls on groundwater flow. A hydrogeologic framework was developed for the alluvium and terrace deposits of the Salt Fork Red River aquifer and included updated definitions of the three-dimensional aquifer extent and potentiometric surface, as well as a description of the textural and hydraulic properties of aquifer materials. The hydrogeologic framework was used in the construction of the numerical groundwater-flow model of the Salt Fork Red River aquifer (Smith and others, 2021) described in this report.

\section{Aquifer Extent}

The geographic extent of the Salt Fork Red River aquifer was updated from the OWRB (2019b) by using information obtained from detailed geologic maps (Stanley, 2004; Stanley and Miller, 2004). The small terrace lobe near Vinson, Okla., was not included in the aquifer extent because it had no saturated thickness during field inspection during 2015-16 and, based on major-ion concentrations in historical groundwaterquality samples (USGS, 2019), was composed primarily of the Whitehorse Group of Permian age (fig. 12). The Mulberry Creek and Horse Branch terraces were retained in the aquifer extent but were believed to have minimal saturated thickness during most of the study period. Irrigation wells in the Mulberry Creek terrace also penetrated and produced supplemental water from the underlying Blaine Formation according to available lithologic logs and groundwater-quality data (OWRB, 2019a; USGS, 2019; fig. 12). The most notable changes from the OWRB (2019b) aquifer extent (not shown in this report) were the removal of (1) an area north-northwest of East Duke (figs. 9 and 12) which was known to produce water from the Blaine Formation (Schoff, 1948) and (2) an area connecting the Mangum terrace and the Martha terrace. Contrary to the updated geologic maps (Stanley, 2004; Stanley and Miller, 2004), the east-west trending strip of land between the Dodson terrace and the Salt Fork Red River alluvium in Harmon County was included in the aquifer extent because it may be covered by intermittent terrace deposits laterally based on several lines of evidence including aerial photography (Microsoft Corporation, 2018), a 1991 aquifer map (Johnson, 1991), permitted well locations (OWRB, 2019d), groundwater-quality samples (USGS, 2019), and available well completion reports and test-hole data (OWRB, 2019a; USGS, 2019). In the area of well 344841099521001 in the Dodson terrace (fig. 12), for example, a production well produced freshwater with major-ion concentrations consistent with those of water of the Salt Fork Red River aquifer from unusually deep (230-ft) wells at the margin of the terrace deposits depicted by Stanley and Miller (2004). No geologic controls are known in that area that explain how the terrace deposits could abruptly decrease in thickness from $230 \mathrm{ft}$ to $0 \mathrm{ft}$. The aquifer extent also was expanded near the towns of Martha, Olustee, and Elmer, Okla., to include areas where permitted wells were thought to draw water from the Salt Fork Red River aquifer.

The coarser Permian-age bedrock units of the study area sometimes resemble the alluvium and terrace deposits, especially in lithologic log descriptions. The horizontal and vertical extents of the Salt Fork Red River aquifer, as defined in this report, may therefore include parts of the Whitehorse Group in the Dodson terrace and parts of the Duncan Sandstone in the Martha terrace. The generally subtle topography of the Martha terrace (fig. 11C) causes increased uncertainty in the surface location of bedrock contacts in that area.

Where present, the top of the Salt Fork Red River aquifer was defined as the land-surface altitude obtained from a 10-meter (horizontal resolution) digital elevation model (DEM) (USGS, 2015). The altitude of the base of the Salt Fork Red River aquifer, which was equivalent to the top of the Permian-age bedrock, was contoured from bedrock depths obtained from well completion reports and test-hole data (OWRB, 2019a; USGS, 2019), direct-push Geoprobe test holes, and horizontal to vertical spectral ratios (HVSR) seismic data points (fig. 13). For each of these data sources, the altitude of the base of the aquifer was calculated by subtracting the measured bedrock depth from the land-surface altitude. For consistency, the land-surface altitude was obtained from a 10-meter DEM, even when the data source provided a land-surface altitude. The bedrock-depth data sources were assumed to have different levels of accuracy and, therefore, were prioritized (most accurate data given highest priority) when contouring the bedrock (base) altitudes of the Salt Fork Red River aquifer (fig. 13). Where the data sources conflicted in a part of the aquifer, the higher priority data source was used to guide the contours; the bedrock-depth data sources are discussed next in order of decreasing priority.

Selected wells completed in the Salt Fork Red River aquifer in Oklahoma (USGS, 2019; fig. 13) (and adjacent Seymour aquifer in Texas [Smith, 1970; Texas Water Development Board, 2019; USGS, 2019]) were assumed to fully penetrate the aquifer, and their well depths were assumed to be equal to the bedrock depth. Bedrock depths from these wells were given the highest priority because they had each been visited and checked by groundwater hydrologists. Other wells (and test holes) included reports with drillers' lithologic logs (OWRB, 2019a; fig. 13) that were searched for terms representing consolidated Permian-age bedrock units (such as "redbed," "gypsum," and "bedrock"). The altitude associated with the first occurrence of these terms in the logs was used as the altitude of the aquifer base. For logs that did not fully penetrate the Salt Fork Red River aquifer (did not include a bedrock-related term), the altitude associated with the hole depth listed on the lithologic log was assumed to be the maximum possible altitude of the aquifer base at that location. Well completion reports and lithologic logs were available for most of the aquifer extent, but few were available near the major 


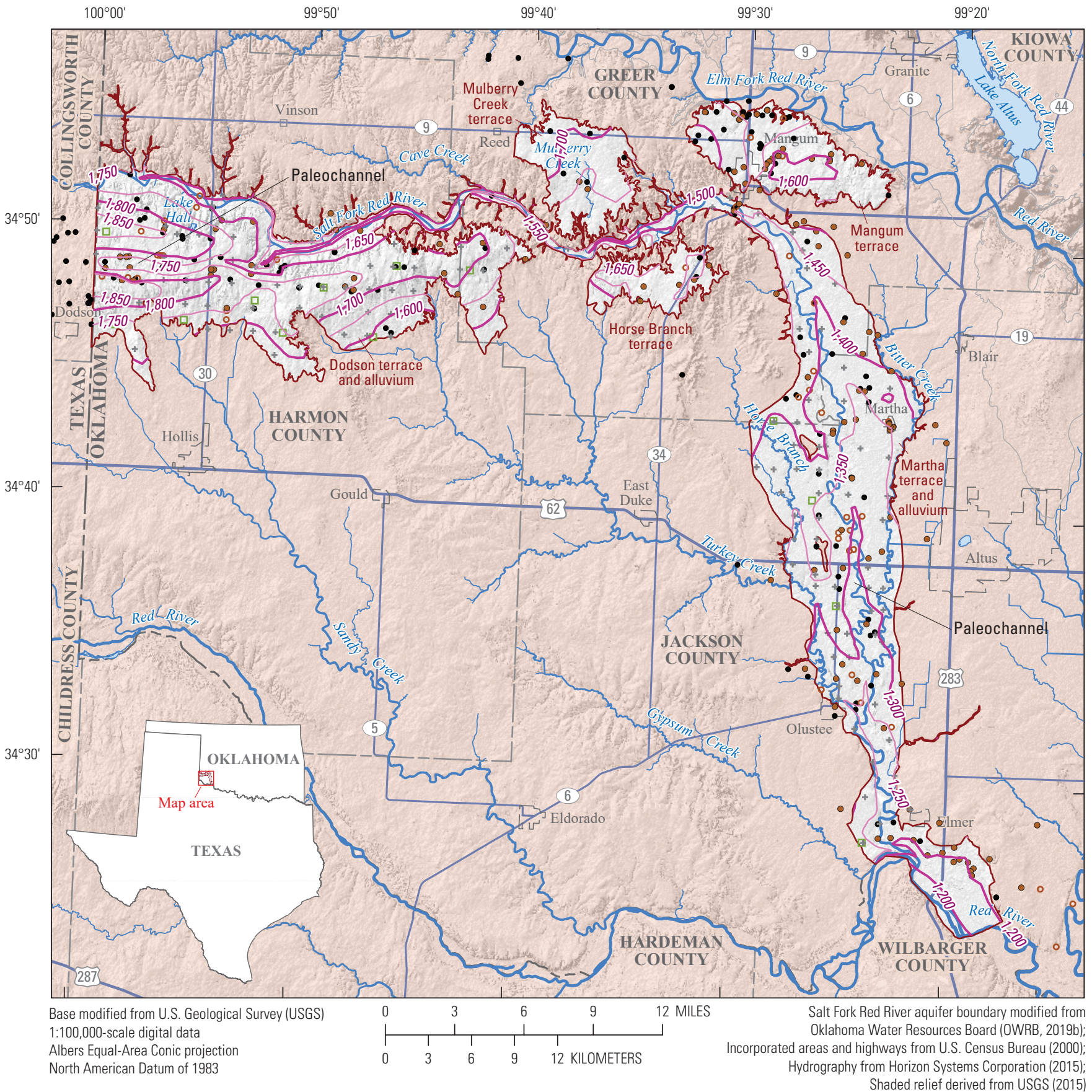

EXPLANATION

Salt Fork Red River aquifer

-1,500- Aquifer-base contour-Shows the altitude of bedrock surface in feet above North American Vertical Datum of 1988. Interval is 50 feet
Location with bedrock-depth measurement (data sources listed in order of increasing priority)

+ Horizontal to vertical spectral ratios (HVSR) seismic site (USGS, 2019)

ㅁ Geoprobe bedrock-depth test hole (USGS, 2019)

- Well or test hole with driller's lithologic log, partially penetrating (OWRB, 2019a)
- Well or test hole with driller's lithologic log, fully penetrating (OWRB, 2019a)

- Well, visited and checked by groundwater hydrologists (Smith, 1970; Texas Water Development Board, 2019; USGS, 2019)

Figure 13. The altitude of the base of the Salt Fork Red River aquifer in southwestern Oklahoma. 
streams of the study area. To provide some bedrock-altitude control in areas near major streams, synthetic logs were placed at about every mile on the major streams and given an aquifer base altitude that was $35 \mathrm{ft}$ below land surface; this 35 -ft estimate was the approximate mean depth of near-stream test-hole and cross-section data reported in literature focused near the study area (Barclay and Burton, 1953; Burton, 1965; Hollowell, 1965a, b).

Thirteen Geoprobe bedrock-depth test holes (USGS, 2019; sites not listed in table 1; instead, site information is available in Smith and others [2021]) were drilled in the Salt Fork Red River aquifer. Those test holes reached a mean depth of about $25 \mathrm{ft}$ in the aquifer, but some may have stopped at impenetrable caliche layers before reaching the full depth to bedrock. The accuracy of bedrock depths obtained by using those test holes is unknown.

HVSR seismic data (fig. 1; USGS, 2019; sites not listed in table 1; instead, site information is available in Smith and others [2021]) were used to estimate the depth to bedrock at 123 sites during 2016-17. At each site, a Tromino (2012) digital seismometer was oriented to geographic north and pushed into a flat area of bare ground, allowing the stabilizing spikes on the bottom of the unit to firmly anchor into the soil. The Tromino (2012) digital seismometer was then leveled and set to record for 10-30 minutes, a timeframe recommended in the instrumentation guidelines (Bard and SESAME-Team, 2004) for the estimated thickness of the alluvial deposits. During that timeframe, the Tromino (2012) digital seismometer gathered ambient seismic shear waves, measuring the frequency and amplitude of shear waves along two horizontal axes and one vertical axis. Unconsolidated alluvial deposits have a slower shear-wave velocity than that of the consolidated bedrock; this contrast in shear-wave velocities causes the horizontal to vertical ratio of the velocities to form a peak from which a measurable resonant frequency of the consolidated bedrock is attained by using a postprocessing software package (Tromino, 2017) provided by the digital seismometer manufacturer. Bedrock depth was estimated from this resonant frequency according to the following equation from Tromino (2012):

$$
Z=V_{S} /\left(4 F_{0}\right)
$$

where

$$
\begin{gathered}
Z \quad \begin{array}{c}
\text { is the depth to bedrock, in meters (converted } \\
\text { to feet for use in this report); }
\end{array} \\
V_{S} \quad \begin{array}{l}
\text { is the shear-wave velocity of the } \\
\text { unconsolidated alluvial deposits, in meters } \\
\text { per second; and }
\end{array} \\
F_{0} \quad \begin{array}{l}
\text { is the resonant frequency of the consolidated } \\
\text { bedrock, in hertz. }
\end{array}
\end{gathered}
$$

In general, HVSR seismic methods probably are less accurate than more direct methods of estimating the depth to bedrock such as drilling and borehole logging. Chandler and Lively (2014) collected HVSR seismic measurements at 41 control points of known depth in Minnesota glacial deposits. About 10 percent of those measurements had errors greater than 25 percent, and about 37 percent of those measurements had errors greater than 15 percent.

The altitude of the base of the Salt Fork Red River aquifer was contoured at 50 - $\mathrm{ft}$ intervals from these prioritized bedrock-depth data sources. An east-west paleochannel (mostly defined by the 1,750-ft aquifer-base contour; fig. 13) was mapped in the western part of the Dodson terrace, which continues westward into the adjacent deposits of the Seymour aquifer in Texas. This paleochannel contains the thickest accumulation of sediment in the Salt Fork Red River aquifer (fig. 13). A less pronounced north-south paleochannel (fig. 13), aligned with most of the permitted irrigation wells in Greer and Jackson Counties (fig. 6), was mapped from northwest of Martha to south of Elmer in the Martha terrace.

\section{Potentiometric Surface}

Potentiometric-surface maps show the altitude at which the water level would have stood in tightly cased wells at a specified time; the potentiometric surface is usually contoured or spatially interpolated from synoptic water-table-altitude measurements in many wells across the aquifer extent. Those maps are useful for showing the general directions of groundwater flow in the aquifer. Groundwater generally flows perpendicular to potentiometric contours in the direction of decreasing contour altitudes.

Steele and Barclay (1965) published an early (1954) potentiometric-surface map for the Salt Fork Red River aquifer and the underlying Permian-age bedrock units (including the Dog Creek Shale, Blaine Formation, and Flower-pot Shale). The 1954 potentiometric-surface map represents conditions during one of the most severe drought periods on record (figs. $4 A-C$ ), and water levels depicted on that map likely were below mean historical water levels. Runkle and McLean (1995) published a 1988 potentiometric-surface map, but it was limited in scope to the Blaine Formation. In both maps, regional flow in the Permian-age bedrock was generally to the southeast.

A 2016 potentiometric surface (fig. 14) for the Salt Fork Red River aquifer was contoured primarily from synoptic water-level altitudes measured during March 14-16, 2016, in 35 selected wells (USGS, 2019; sites not listed in table 1; instead, site information is available in Smith and others [2021]). These water-level altitudes were measured by using standard USGS methods (Cunningham and Schalk, 2011). Approximated water-level altitudes from selected drillers' lithologic logs (OWRB, 2019a) also were used in areas with sparse water-level data; those water-level altitudes were from a variety of dates during the study period. USGS field hydrographer notes indicated that the small, isolated terraces to the west and southwest of Mangum were mostly unsaturated in March 2016. The 2016 potentiometric surface was highest along the western border with Texas and lowest along the Red River. Local flow in the Salt Fork Red River aquifer is generally from areas of high topographic relief toward the Salt 


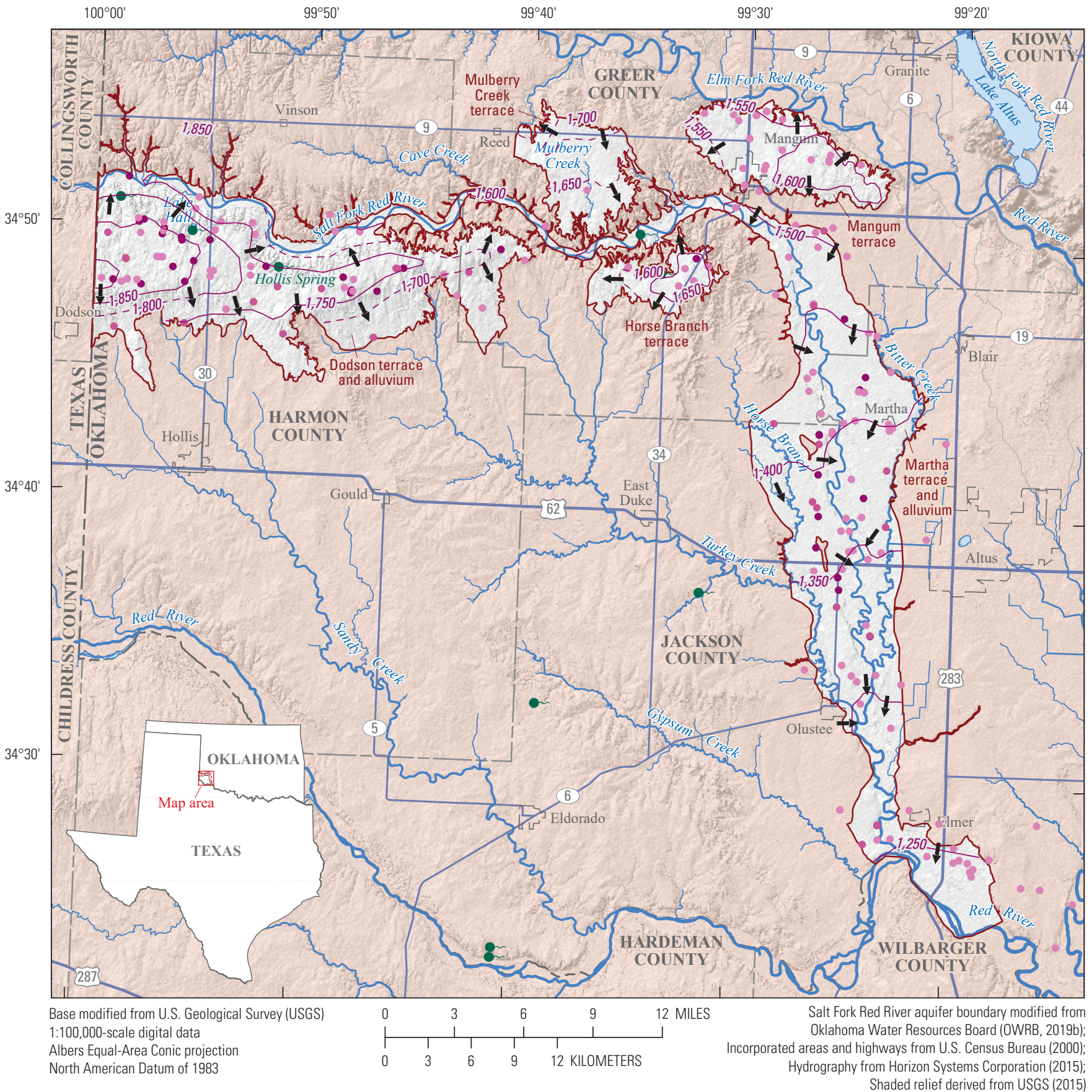

\begin{tabular}{|l|l} 
Salt Fork Red River aquifer & EXPLANATION \\
\hline $1,550--\begin{array}{c}\text { Potentiometric-surface contour, 2016-Shows } \\
\text { the altitude in feet at which the water level } \\
\text { would have stood in tightly cased wells. } \\
\text { Datum is North American Vertical Datum } \\
\text { of 1988. Interval is 50 feet. Dashed where } \\
\text { approximately located }\end{array}$ & $\begin{array}{c}\text { Well or test hole with depth-to-water } \\
\text { measurement, 2016 }\end{array}$ \\
\hline
\end{tabular}

Figure 14. Potentiometric-surface contours and general direction of groundwater flow in the Salt Fork Red River aquifer, 2016. 
Fork Red River and major tributaries or toward the Elm Fork Red River in the case of the northeastern part of the Mangum terrace or toward headwater tributaries of Turkey and Sandy Creeks in the case of the southern part of the Dodson terrace (fig. 14). The general patterns and directions of groundwater flow were similar for the 1954 and 2016 potentiometricsurface maps. The 2016 contours were located upgradient from 1954 contours (of equal value) in some areas, however, indicating that the potentiometric surface in those areas was lower in 2016 than in 1954.

\section{Textural and Hydraulic Properties of Aquifer Materials}

The distribution and variability of textural and hydraulic properties of aquifer materials, especially the horizontal hydraulic conductivity, were assumed to be the primary controls on groundwater flow in the Salt Fork Red River aquifer. Multiple methods were used to estimate the range and central tendency of horizontal hydraulic conductivity values in the Salt Fork Red River aquifer. These methods included in place estimation, analysis of core material, and summary of data in drillers' lithologic logs.

\section{Horizontal Hydraulic Conductivity Estimated in Test Holes and Cores}

A direct-push Geoprobe hydraulic profiling tool (HPT; Geoprobe Systems, 2015) was used at 12 sites (table 5, fig. 1) to obtain in place estimates of horizontal hydraulic conductivity by using the McCall (2010) method. Site selection was based on site access and availability of historical lithologic logs in the area. During drilling, the HPT injected water into the aquifer material while logging electrical conductivity, injection pressure (corrected for hydrostatic gradient in the saturated zone), and injection flow rate at 0.05 -ft depth intervals (Geoprobe Systems, 2015). The Direct Image Viewer (version 3.0) software package (Geoprobe Systems, 2020) was used to calculate discrete horizontal hydraulic conductivity values with depth by using the ratio of the injection flow rate and the hydrostatic-corrected injection pressure. This method (McCall, 2010) can be used in the saturated zone to estimate horizontal hydraulic conductivity values of as much as 150 feet per day $(\mathrm{ft} / \mathrm{d})$. The HPT test holes were drilled to a depth of refusal, which was assumed to be the bedrock contact. Caliche layers, however, may have prevented the HPT from reaching the bedrock-contact depth in some test holes. The HPT did not reach the saturated zone in test hole Kh08 and malfunctioned in test holes Kh12, Kh13, and Kh14; the discrete (every $0.05 \mathrm{ft}$ ) HPT horizontal hydraulic conductivity measurements from all other test holes ranged from about 1 to $110 \mathrm{ft} / \mathrm{d}$ and averaged about $51 \mathrm{ft} / \mathrm{d}$ (fig. 15A; Smith and others, 2021), but the distribution of discrete HPT horizontal hydraulic conductivity measurements was somewhat bimodal around $6 \mathrm{ft} / \mathrm{d}$ and $64 \mathrm{ft} / \mathrm{d}$ (fig. 15B).
Selected HPT test-hole sites (table 1) were chosen for additional core sampling by using a Geoprobe Macro-Core MC5 sediment sampling system (Geoprobe Systems, 2011). Cores of 1.5-in. diameter were grouped into zones of similar texture, and those zones were described by noting grain size, sorting, and color by comparison with Munsell (1912) soil color charts (X-Rite, Inc., 2009; Smith and others, 2021). Aquifer material in each zone was grouped into five grain-size categories (clay/silt, fine sand, medium sand, coarse sand, and gravel), and the relative proportion of each sand category (fine sand, medium sand, coarse sand) was quantified. Sievingbased particle-size analysis was performed on selected 0.3 - to $1.1-\mathrm{ft}$ core intervals by using methods of Gee and Or (2002). Selected core intervals were composed predominantly of fine to coarse sand because samples with large gravel or silt/clay fractions were not appropriate for sieving-based particle-size analysis. Samples from selected intervals were dried in a convection oven if necessary, weighed to obtain a dry weight, and then sieved using mechanical agitation for at least $30 \mathrm{~min}$ utes. Stacked sieve pans with mesh sizes of 4.00 millimeters $(\mathrm{mm})$ and $2.00 \mathrm{~mm}$ (gravel), $1.00 \mathrm{~mm}$ and $0.500 \mathrm{~mm}$ (coarse sand), $0.250 \mathrm{~mm}$ (medium sand), $0.125 \mathrm{~mm}$ and $0.062 \mathrm{~mm}$ (fine sand), and a catch pan for fines (silt and clay) were used for sediment-size fraction analysis. After sieving, the relative percent weight retained in each pan was calculated, and the resulting grain-size distributions were used to calculate grain-size statistics for the sieved interval (table 5; Folk and Ward, 1957).

Horizontal hydraulic conductivity values for sieved core intervals were estimated from calculated grain-size statistics by using methods of Hazen (1911) and Shepherd (1989) as described by Fetter (1994). The Shepherd (1989) method for unconsolidated channel deposits relates horizontal hydraulic conductivity ( $K h$, in feet per day) to the graphic-mean grainsize (diameter) statistic (Folk and Ward, 1957; $d_{\text {mean }}$, in millimeters) by the equation:

$$
K h=450\left(d_{\text {mean }}\right)^{1.65}
$$

The Hazen (1911) method relates horizontal hydraulic conductivity ( $K h$, in centimeters per second) to the effective grain-size (diameter) statistic (Folk and Ward, 1957; $d_{10}$, in centimeters) by the equation:

$$
K h=C\left(d_{10}\right)^{2}
$$

where

$$
\begin{gathered}
C \quad \text { is an empirical coefficient ranging from } 40 \text { to } \\
150 \text { per centimeter-second for poorly } \\
\text { sorted, very fine grained sand and well } \\
\text { sorted coarse-grained sand, respectively. }
\end{gathered}
$$

For each sieved core interval, lower and upper bounds for $C$ (table 5) were selected based on the textural composition of that interval as described in the core $\log$. These bounds for $C$, which are directly proportional to lower and upper bounds for 
Table 5. Hydraulic properties calculated from Geoprobe hydraulic profiling tool (HPT) test holes and cored test holes in the Salt Fork Red River aquifer.

[--, not available or not applicable; $\mathrm{C}$, empirical coefficient; mm, millimeters; $\mathrm{cm}^{-1} \mathrm{~s}^{-1}$, per centimeter-second; *, gravel omitted; **, calculated over available part of sieved interval. The Kh09 core was not described, and the Kh08, Kh12, and Kh13 cores were not sieved. Geoprobe HPT and cored test-hole data are available in the associated data release (Smith and others, 2021)]

\begin{tabular}{|c|c|c|c|c|c|c|c|c|c|c|c|c|c|c|c|c|c|c|}
\hline \multirow{3}{*}{$\begin{array}{c}\text { Station } \\
\text { identifier } \\
\text { (table 1, } \\
\text { fig. 1) }\end{array}$} & \multirow{3}{*}{$\begin{array}{c}\text { HPT } \\
\text { depth, } \\
\text { in feet } \\
\text { below } \\
\text { land } \\
\text { surface }\end{array}$} & \multirow{3}{*}{$\begin{array}{c}\text { HPT } \\
\text { depth } \\
\text { to } \\
\text { water, } \\
\text { in feet } \\
\text { below } \\
\text { land } \\
\text { surface }\end{array}$} & \multirow{3}{*}{$\begin{array}{c}\text { HPT mean } \\
\text { horizontal } \\
\text { hydraulic } \\
\text { conduc- } \\
\text { tivity, in } \\
\text { feet per } \\
\text { day }\end{array}$} & \multirow{3}{*}{$\begin{array}{c}\text { Total } \\
\text { cored } \\
\text { depth, in } \\
\text { feet be- } \\
\text { low land } \\
\text { surface }\end{array}$} & \multicolumn{2}{|c|}{$\begin{array}{l}\text { Sieved interval, } \\
\text { in feet below } \\
\text { land surface }\end{array}$} & \multirow{3}{*}{$\begin{array}{c}\text { Length } \\
\text { of sieved } \\
\text { interval, } \\
\text { in feet }\end{array}$} & \multicolumn{4}{|c|}{$\begin{array}{l}\text { Grain-size statistics of sieved interval, } \\
\text { in millimeters (Folk and Ward, 1957) }\end{array}$} & \multicolumn{2}{|c|}{$\begin{array}{c}\text { C, in } \\
\mathrm{cm}^{-1} \mathbf{s}^{-1}\end{array}$} & \multicolumn{5}{|c|}{$\begin{array}{l}\text { Estimated horizontal hydraulic conductivity of } \\
\text { sieved core interval, in feet per day }\end{array}$} \\
\hline & & & & & & & & \multirow{2}{*}{$\begin{array}{l}\text { Effective } \\
\text { grain } \\
\text { size }\left(d_{10}\right)\end{array}$} & \multirow{2}{*}{$\begin{array}{c}\text { Median } \\
\text { grain } \\
\text { size } \\
\left(d_{50}\right)\end{array}$} & \multirow{2}{*}{$\begin{array}{c}\text { Graphic } \\
\text { mean } \\
\text { grain } \\
\text { size } \\
\left(d_{\text {mean }}\right)\end{array}$} & \multirow{2}{*}{$\begin{array}{c}\text { Inclusive } \\
\text { graphic } \\
\text { standard } \\
\text { deviation }\end{array}$} & \multicolumn{2}{|c|}{ Hazen, 1911} & \multicolumn{3}{|c|}{ Hazen, 1911} & \multirow{2}{*}{$\begin{array}{c}\text { Shepherd, } \\
1989 \text { (for } \\
\text { channel } \\
\text { deposits) } \\
\begin{array}{c}\text { Interval } \\
\text { mean }\end{array}\end{array}$} & \multirow{2}{*}{$\begin{array}{c}\text { From } \\
\text { Geoprobe } \\
\text { HPT } \\
\text { data** }^{*} \\
\begin{array}{c}\text { Interval } \\
\text { mean }\end{array}\end{array}$} \\
\hline & & & & & & & & & & & & $\begin{array}{l}\text { Lower } \\
\text { bound }\end{array}$ & $\begin{array}{l}\text { Upper } \\
\text { bound }\end{array}$ & $\begin{array}{l}\text { Lower } \\
\text { bound }\end{array}$ & $\begin{array}{l}\text { Upper } \\
\text { bound }\end{array}$ & $\begin{array}{l}\text { Midpoint } \\
\text { value }\end{array}$ & & \\
\hline \multirow[t]{2}{*}{ Kh01 } & 14.7 & 10.4 & 15.2 & 24.0 & 8.8 & 9.6 & 0.8 & 0.08 & 0.12 & 0.17 & 0.07 & 40 & 80 & 7.3 & 14.5 & 10.9 & 23.4 & -- \\
\hline & & & & & 15.7 & 16.0 & $0.3^{*}$ & 0.20 & 0.42 & 0.67 & 0.40 & 80 & 150 & 90.7 & 170.1 & 130.4 & 230.5 & -- \\
\hline \multirow[t]{2}{*}{ Kh02 } & 17.5 & 10.1 & 39.6 & 24.0 & 9.3 & 9.7 & 0.4 & 0.18 & 0.27 & 0.36 & 0.15 & 80 & 120 & 73.5 & 110.2 & 91.8 & 84.7 & 60.5 \\
\hline & & & & & 21.1 & 21.6 & 0.5 & 0.16 & 0.22 & 0.30 & 0.14 & 40 & 80 & 29.0 & 58.1 & 43.5 & 62.9 & -- \\
\hline \multirow[t]{2}{*}{$\mathrm{Kh} 03$} & 41.0 & 3.8 & 52.7 & 16.0 & 11.4 & 12.0 & 0.6 & 0.14 & 0.24 & 0.34 & 0.17 & 80 & 120 & 44.4 & 66.7 & 55.6 & 74.7 & 68.0 \\
\hline & & & & & 12.7 & 13.2 & 0.5 & 0.21 & 0.35 & 0.51 & 0.28 & 80 & 120 & 100.0 & 150.0 & 125.0 & 149.8 & 66.9 \\
\hline Kh04 & 30.7 & 1.2 & 58.3 & 27.0 & 9.9 & 10.4 & 0.5 & 0.19 & 0.31 & 0.40 & 0.19 & 80 & 120 & 81.9 & 122.8 & 102.3 & 97.9 & 63.4 \\
\hline \multirow[t]{2}{*}{ Kh07 } & 20.2 & 17.5 & 10.9 & 27.8 & 1.6 & 2.0 & 0.4 & 0.12 & 0.20 & 0.29 & 0.16 & 40 & 80 & 16.3 & 32.7 & 24.5 & 59.5 & -- \\
\hline & & & & & 22.2 & 23.0 & 0.8 & 0.14 & 0.22 & 0.33 & 0.17 & 80 & 120 & 44.4 & 66.7 & 55.6 & 72.2 & -- \\
\hline Kh08 & 7.2 & -- & -- & -- & -- & -- & -- & -- & -- & -- & -- & -- & -- & -- & -- & -- & -- & -- \\
\hline Kh09 & 13.4 & 2.7 & 63.2 & -- & 10.6 & 11.4 & 0.8 & 0.22 & 0.33 & 0.39 & 0.13 & 80 & 120 & 109.8 & 164.6 & 137.2 & 96.5 & 72.5 \\
\hline Kh10 & 25.0 & 4.7 & 50.5 & 29.3 & 21.8 & 22.3 & $0.5^{*}$ & 0.25 & 0.36 & 0.50 & 0.25 & 80 & 120 & 141.7 & 212.6 & 177.2 & 143.4 & 3.0 \\
\hline Kh11 & 21.6 & 3.0 & 41.6 & 24.0 & 21.2 & 21.8 & 0.6 & 0.08 & 0.17 & 0.26 & 0.16 & 40 & 80 & 7.3 & 14.5 & 10.9 & 49.8 & -- \\
\hline Kh12 & 14.9 & 7.8 & -- & 15.0 & -- & -- & -- & -- & -- & -- & -- & -- & -- & -- & -- & -- & -- & -- \\
\hline Kh13 & 31.4 & 10.4 & -- & 24.0 & -- & -- & -- & -- & -- & -- & -- & -- & -- & -- & -- & -- & -- & -- \\
\hline \multirow[t]{2}{*}{ Kh14 } & 17.6 & 16.7 & -- & 32.0 & 14.4 & 15.5 & 1.1 & 0.12 & 0.19 & 0.28 & 0.14 & 40 & 80 & 16.3 & 32.7 & 24.5 & 55.1 & -- \\
\hline & & & & & 18.4 & 18.9 & 0.5 & 0.08 & 0.18 & 0.26 & 0.14 & 40 & 80 & 7.3 & 14.5 & 10.9 & 47.7 & -- \\
\hline Mean & -- & -- & -- & -- & -- & -- & 0.6 & 0.16 & 0.26 & 0.36 & 0.18 & 63 & 105 & 55.0 & 87.9 & 71.4 & 89.1 & 55.7 \\
\hline
\end{tabular}



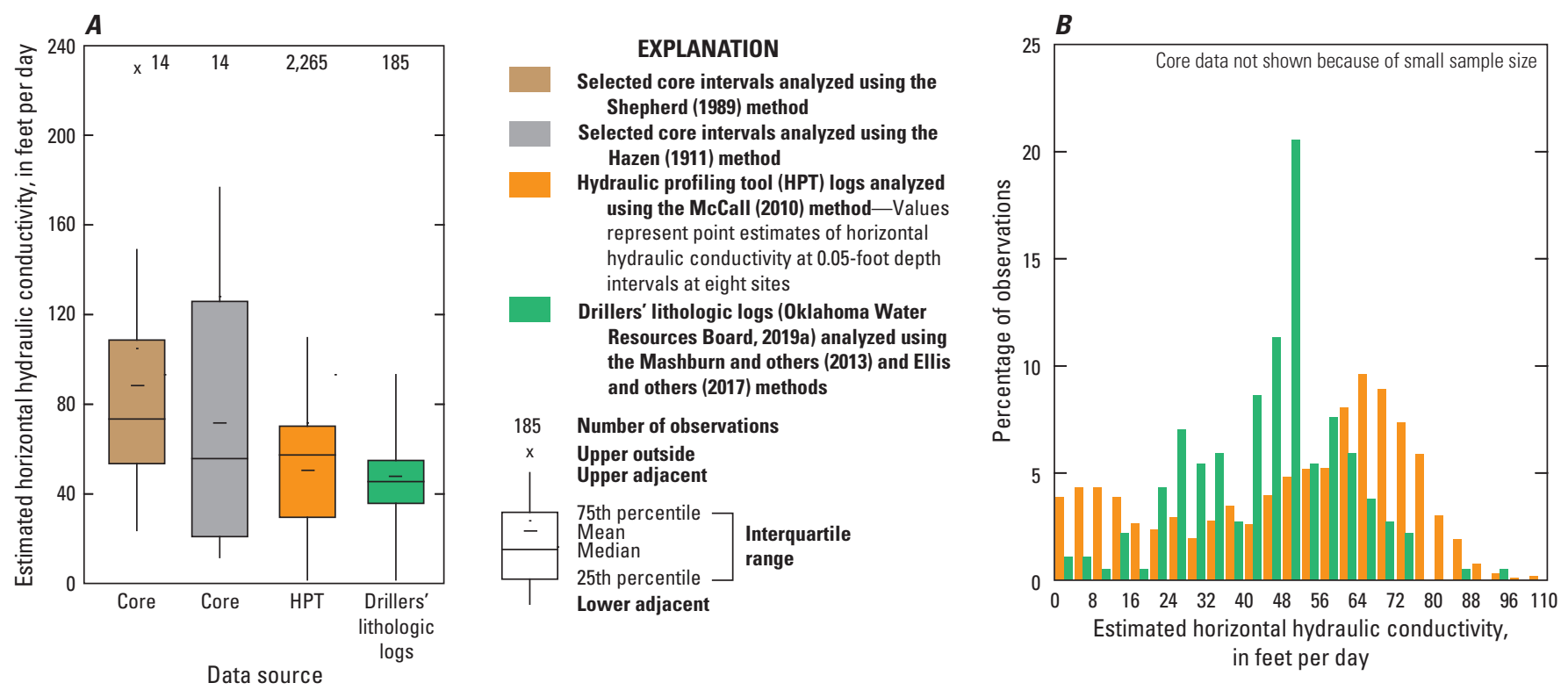

Figure 15. Distributions of estimated horizontal hydraulic conductivity observations in the Salt Fork Red River aquifer.

estimated horizontal hydraulic conductivity, were intended to communicate the uncertainty associated with selection of $C$ values. The midpoint value of horizontal hydraulic conductivity estimated with the Hazen (1911) method is simply the mean of the lower and upper bounds of estimated horizontal hydraulic conductivity. Horizontal hydraulic conductivities in the different test-hole core intervals ranged from 10.9 to $177.2 \mathrm{ft} / \mathrm{d}$ for midpoint values calculated using the Hazen (1911) method and from about 23.4 to $230.5 \mathrm{ft} / \mathrm{d}$ for interval means calculated using the Shepherd (1989) method (table 5, fig. 15A). The mean horizontal hydraulic conductivity across all test-hole core intervals was $71.4 \mathrm{ft} / \mathrm{d}$ using the Hazen (1911) method and $89.1 \mathrm{ft} / \mathrm{d}$ using the Shepherd (1989) method. These mean horizontal hydraulic conductivity values may be overestimated, however, because analysis with the Hazen (1911) and Shepherd (1989) methods requires omission of the silt/clay fraction (0.3-9.8 percent by weight) in coreinterval samples. Gravel, which also must be omitted, was found in only two core-interval samples.

\section{Horizontal Hydraulic Conductivity Estimated from Lithologic Logs}

Drillers' lithologic logs also were used to estimate the horizontal hydraulic conductivity of aquifer materials. Textural terms in each lithologic log (OWRB, 2019a) were standardized, categorized, and converted to percentage-coarsematerial values by using the methods of Mashburn and others (2013). Ellis and others (2017) developed an equation relating core-derived percentage-coarse-material values to horizontal hydraulic conductivity for alluvium and terrace deposits in the
Canadian River aquifer of west-central Oklahoma; that equation was used in this report to estimate horizontal hydraulic conductivity values for lithologic logs in the Salt Fork Red River aquifer.

Lithologic logs included terms such as "gravel," "sand," "silt," and "clay" to describe the texture of unconsolidated alluvium and terrace deposits of the Salt Fork Red River aquifer; however, terms used for lithologic descriptions varied between drillers. To simplify and standardize the lithologic logs, lithologic descriptions of unconsolidated deposits were reclassified into five lithologic categories (clay, silt, fine sand, coarse sand, and gravel) that were assumed to have quintile ranges of percentage-coarse material $(0-20,20-40,40-60$, $60-80$, and $80-100$ percent coarse material, respectively). The midpoint of the respective quantile range $(10,30,50,70$, or 90 percent coarse material, respectively) was then assigned to each lithologic depth interval. The percentage-coarse-material value for each lithologic log was computed as the thicknessweighted mean of percentage-coarse-material values assigned to the unconsolidated lithologic categories in the log. The maximum percentage-coarse-material value for any lithologic log was 90 percent (all gravel), and the minimum percentagecoarse-material value for any lithologic log was 10 percent (all clay). A total of 185 lithologic logs (OWRB, 2019a) were used for the percentage-coarse-material analysis, and at least 138 of those logs fully penetrated the aquifer. Logs with obvious error resolutions were corrected to extract as much useful information as possible; logs with inscrutable errors were discarded. The lithologic-log-computed horizontal hydraulic conductivity ranged from about 0.1 to $93 \mathrm{ft} / \mathrm{d}$ with a mean of about $45 \mathrm{ft} / \mathrm{d}$ (fig. 15A). 


\section{Vertical Anisotropy and Storage Properties}

The vertical anisotropy (ratio of horizontal to vertical hydraulic conductivity), specific yield, and specific storage of aquifer materials have not been measured in the Salt Fork Red River aquifer. Also, no sites suitable for a multiwell aquifer test were identified during field investigations, and multiwell aquifer tests from the Seymour aquifer in Wilbarger County (fig. 1) were not of sufficient duration to obtain valid estimates of specific yield and specific storage (Willis and Knowles, 1953). The vertical anisotropy, specific yield, and specific storage, therefore, were assumed to be comparable to those used in simulations of water availability in the nearby North Fork Red River aquifer (Smith and others, 2017a, b; fig. 1). Smith and others $(2017 \mathrm{a}, \mathrm{b})$ used vertical anisotropy, specific yield, and specific storage values of $3.0,0.12$, and $1 \times 10^{-5}$, respectively; these values were each within the range suggested by Domenico and Schwartz (1998) for unconsolidated aquifer materials like those of the Salt Fork Red River aquifer.

\section{Conceptual Groundwater-Flow Model}

A conceptual groundwater-flow model (hereinafter referred to as the "conceptual model") is a simplified description of the major inflow and outflow sources (hydrologic boundaries) of a groundwater-flow system as well as a water-budget accounting of the estimated mean flows from those sources for a specified period. A conceptual model for the Salt Fork Red River aquifer that reasonably represents the groundwater-flow system was developed to constrain the construction and calibration of a numerical groundwater-flow model (hereinafter referred to as the "numerical model"). The conceptual-model water budget (table 6, fig. 16A) estimated mean annual inflows to, and outflows from, the Salt Fork Red River aquifer for the period 1980-2015 and included a subaccounting of mean annual inflows and outflows for the portions of the aquifer that were upgradient and downgradient from the Mangum gage (fig. 1); the Mangum terrace was included in the portion downgradient from the Mangum gage. The isolated and mostly unsaturated Mulberry Creek and Horse Branch terraces were omitted from the conceptual model. Minus the area of those terraces (19,764 acres), the conceptual-model (and numerical-model) aquifer area totaled 155,929 acres (table 6).

Estimated flows to hydrologic boundaries of the conceptual model have varying levels of uncertainty. Where possible, those estimated flows were based on field measurements from the study area and study period. In cases where field measurements were unavailable or too difficult or expensive to obtain, estimated flows of the conceptual model were assumed to be roughly proportional to those of published conceptual models from similar aquifers in western Oklahoma (Ryter and Correll, 2016; Ellis and others, 2017). The conceptual model for the North Fork Red River aquifer (Smith and others, 2017a), however, was used as the predominant analog because of its proximity and similarity to the Salt Fork Red River aquifer.
The "Notes" section of table 6 summarizes many of the data sources and analog-based assumptions used to construct the conceptual-model water budget for the Salt Fork Red River aquifer.

\section{Hydrologic Boundaries}

Hydrologic boundaries in the conceptual model represent real-world sources (inflows) and sinks (outflows) of water to and from the aquifer. Boundaries that act as both inflows and outflows may be referred to as net inflows or outflows depending on which flow component dominates.

\section{Recharge}

Recharge is the predominant inflow to the Salt Fork Red River aquifer. Recharge, as defined in this report, is the amount of precipitation that reaches the saturated zone by the process of infiltration through the unsaturated zone over a given time. This definition of recharge includes irrigation return flows to groundwater. Factors that affect recharge rates are precipitation rates, evapotranspiration rates, permeability and moisture capacity of the unsaturated zone, and slope of the land surface. Recharge rates are difficult to measure directly because they vary over short spatial and temporal scales; therefore, recharge rates are often estimated by using multiple methods ranging in scale from local to regional. The basin-scale RORA (Rorabaugh, 1964; Rutledge, 1998) method, which is based on streamgage data, would have been the most appropriate for the scale of this study; unfortunately, the streams in the study area violated the assumptions of this method because they were losing streams during part of the year or they exceeded the recommended drainage-basin area limit of $500 \mathrm{mi}^{2}$.

The water-table fluctuation (WTF) method (Healy and Cook, 2002) was the primary method used to estimate recharge to the Salt Fork Red River aquifer. The WTF method is based on the premise that short-term (hours to a few days) rises in continuously recorded groundwater levels in unconfined aquifers are caused by recharge arriving at the saturated zone following a period of precipitation. Using the WTF method, recharge $(R)$ was calculated as the sum of individual water-level rises in response to precipitation:

$$
R=S y \Delta h / \Delta t
$$

where

Sy is the specific yield (dimensionless),

$\Delta h$ is the change in water level, in inches, and

$\Delta t \quad$ is the change in time, in months.

The WTF method aggregates all types of recharge and cannot separate signals of recharge from precipitation and other sources including irrigation return flow.

Not all sites with continuously recorded groundwater levels are well suited to recharge analysis using the WTF method. The method is ideally applied to karst aquifers with 
Table 6. Conceptual-model water budget for the Salt Fork Red River aquifer, 1980-2015.

[All units in acre-feet per year; --, not quantified or not applicable]

\begin{tabular}{|c|c|c|c|c|c|c|}
\hline \multicolumn{2}{|c|}{ Water-budget category } & $\begin{array}{l}\text { Upgradient from } \\
\text { Mangum gage } \\
\text { (fig. 1, table 1) }\end{array}$ & $\begin{array}{c}\text { Downgradient } \\
\text { from Mangum } \\
\text { gage }^{1}\end{array}$ & Total & \multirow{4}{*}{$\begin{array}{l}\text { Percentage of } \\
\text { water budget }\end{array}$} & \multirow{4}{*}{ Notes } \\
\hline \multirow{3}{*}{ Aquifer area2 } & in cells & 70,464 & 99,343 & 169,807 & & \\
\hline & in acres & 64,705 & 91,224 & 155,929 & & \\
\hline & in percent & 41.5 & 58.5 & 100.0 & & \\
\hline \multicolumn{7}{|c|}{ Inflow } \\
\hline Recharge & & 15,862 & 22,363 & 38,225 & 100.0 & $\begin{array}{l}2.94 \text { inches per year, or } 10 \text { percent of mean annual precipitation, } \\
1980-2015 \text { (table 2) }\end{array}$ \\
\hline $\begin{array}{l}\text { Net change in gr } \\
\text { age }^{3}\end{array}$ & dwater stor- & -- & -- & -- & -- & Assumed to be a negligible part of total budget \\
\hline Net lakebed see & $(\text { Lake Hall })^{3}$ & -- & -- & -- & -- & Assumed to be a negligible part of total budget \\
\hline Total inflow & & 15,862 & 22,363 & 38,225 & 100.0 & \\
\hline \multicolumn{7}{|c|}{ Outflow } \\
\hline \multicolumn{2}{|c|}{ Net streambed seepage ${ }^{3}$} & 8,181 & 15,320 & 23,501 & 59.9 & Calculated from base-flow data at streamgages (table 4) \\
\hline \multicolumn{2}{|c|}{ Saturated-zone evapotranspiration } & 3,112 & 4,388 & 7,500 & 19.1 & $\begin{array}{l}\text { Unknown; assumed to be about } 30 \text { percent of net streambed seep- } \\
\text { age }\end{array}$ \\
\hline \multicolumn{2}{|c|}{ Springs and seeps } & 3,000 & 500 & 3,500 & 8.9 & $\begin{array}{l}\text { Unknown; assumed to be about } 15 \text { percent of net streambed seep- } \\
\text { age }\end{array}$ \\
\hline \multicolumn{2}{|c|}{ Well withdrawals } & 1,007 & 2,447 & 3,533 & 9.0 & Calculated from reported groundwater use (table 3) \\
\hline \multicolumn{2}{|c|}{ Net lateral groundwater flow 3} & 500 & 700 & 1,200 & 3.1 & Unknown; assumed to be about 3 percent of budget \\
\hline \multicolumn{2}{|l|}{ Total outflow } & 15,801 & 23,354 & 39,234 & 100.0 & \\
\hline
\end{tabular}

1The Mangum terrace is included in portion downgradient from Mangum gage (USGS streamgage 07300500 Salt Fork Red River at Mangum, Okla.).

2Aquifer area excludes about 31 square miles (19,764 acres) comprising the Mulberry Creek and Horse Creek terraces.

${ }^{3}$ Net streambed seepage, net lateral groundwater flow, net lakebed seepage, and net change in groundwater storage represent the net effect of aquifer inflows and outflows. 


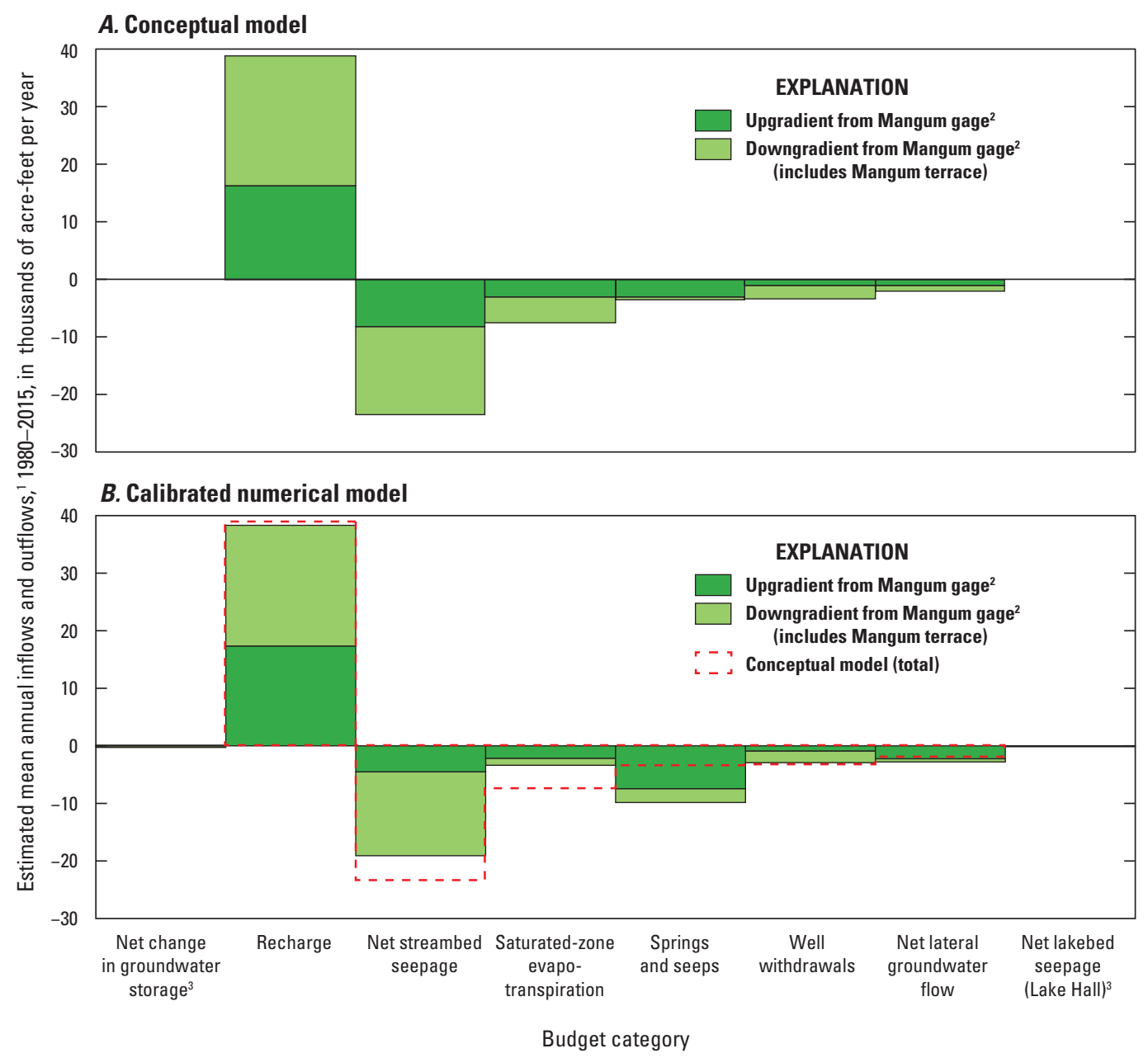

'Mean annual inflows and outflows exclude those from about 31 square miles (19,764 acres) comprising the Mulberry Creek and Horse Creek terraces. ${ }^{2}$ Mangum gage refers to U.S. Geological Survey streamgage 07300500 Salt Fork Red River at Mangum, Okla. (fig. 1, table 1).

${ }^{3}$ The net change in groundwater storage and net lakebed seepage budget categories are small but not zero for the calibrated numerical model.

Figure 16. Estimated mean annual inflows and outflows by water-budget category for the $A$, conceptual model; and B, calibrated numerical model of the Salt Fork Red River aquifer, 1980-2015.

shallow water tables that display rapid water-level rises in response to brief precipitation events. Recharge measurement error presumably increases for porous aquifers that recharge more slowly and, as a result, tend to display more cumulative water-level rises in response to longer duration periods that include multiple precipitation events. Among the continuous water-level recorder wells in the Salt Fork Red River aquifer, SFR03 (fig. 1) was best suited for WTF recharge estimation because the hydrograph from that well displayed the most rapid (peaked) water-level rises (and subsequent declines) in response to precipitation events (fig. 17B). The water-level rises and declines in SFR01 (fig. 17A) were less rapid than those in SFR03 (fig. 17B), but SFR01 also was useful for WTF recharge analysis. Continuous water-level recorder wells SFR00 and SFR05 (fig. 1) were far from ideal for estimating recharge by using the WTF method because the hydrographs from those wells exhibited slow water-level rises over time that represented cumulative precipitation from multiple events (figs. $17 C, D$ ). Although WTF recharge estimates were also obtained for these wells, they were likely underestimated because the effects of recharge events were delayed in the hydrographs. Continuous water-level recorder wells SFR02, SFR04, and SFR06 (fig. 1) were not suitable for estimating recharge (as it is defined in this report) by using the WTF method. Groundwater levels in these wells were strongly influenced by seepage from the nearby Salt Fork Red River. In these three wells, the altitude of the groundwater level is consistently lower than the stage of the Salt Fork Red River, indicating that groundwater always flows from the river to the well location. As further evidence of the influence of nearby stream seepage, the Salt Fork Red River hydrographs closely resemble the continuous water-level hydrographs in terms of magnitude and timing of water-level rises and declines (figs. $17 E, F, G$ ). 

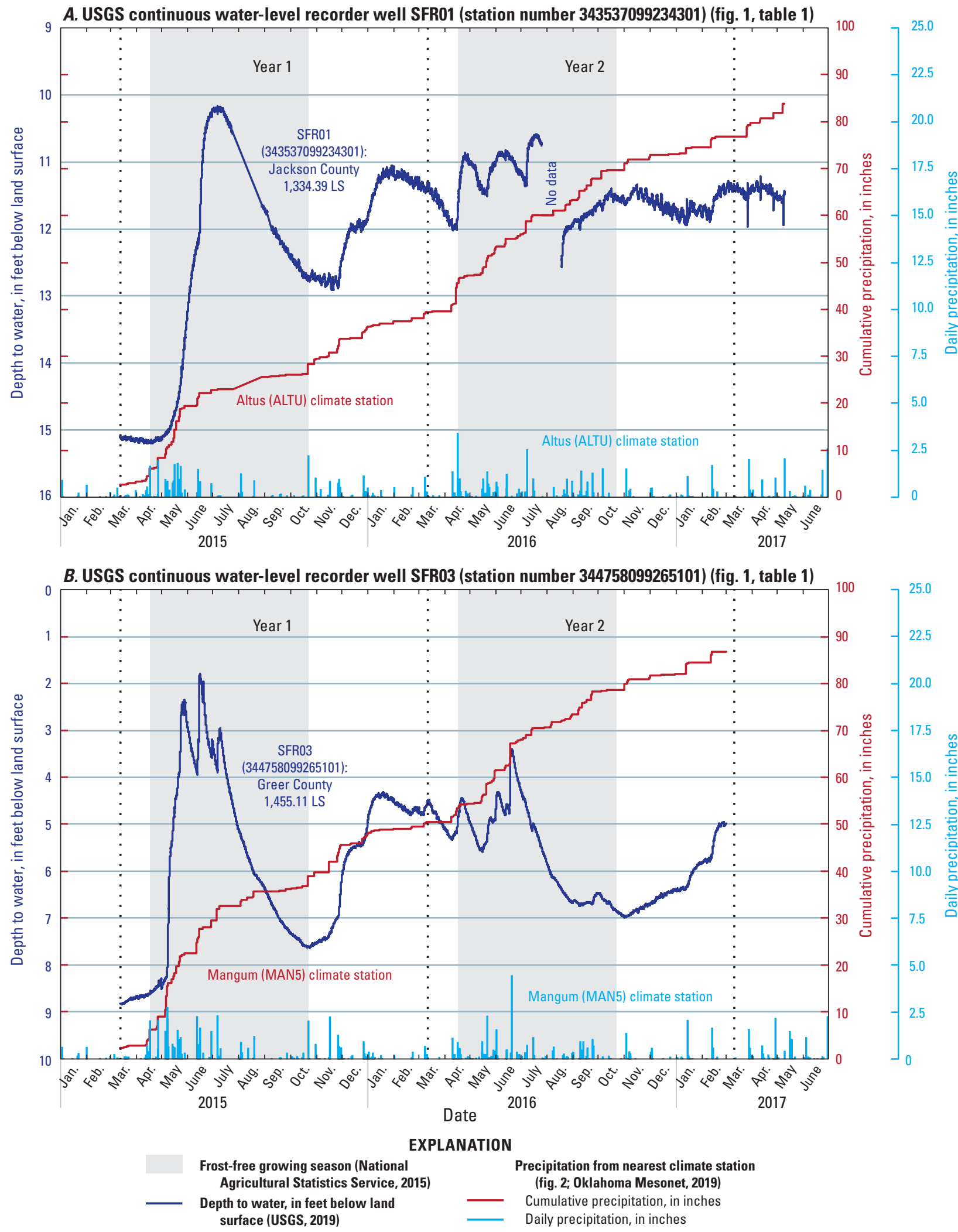

USGS, U.S. Geological Survey

LS, Land surface altitude, in feet above North American Vertical Datum of 1988

Figure 17. Daily and cumulative precipitation and depth to water in continuous water-level recorder wells completed in the Salt Fork Red River aquifer, January 2015-June 2017. 

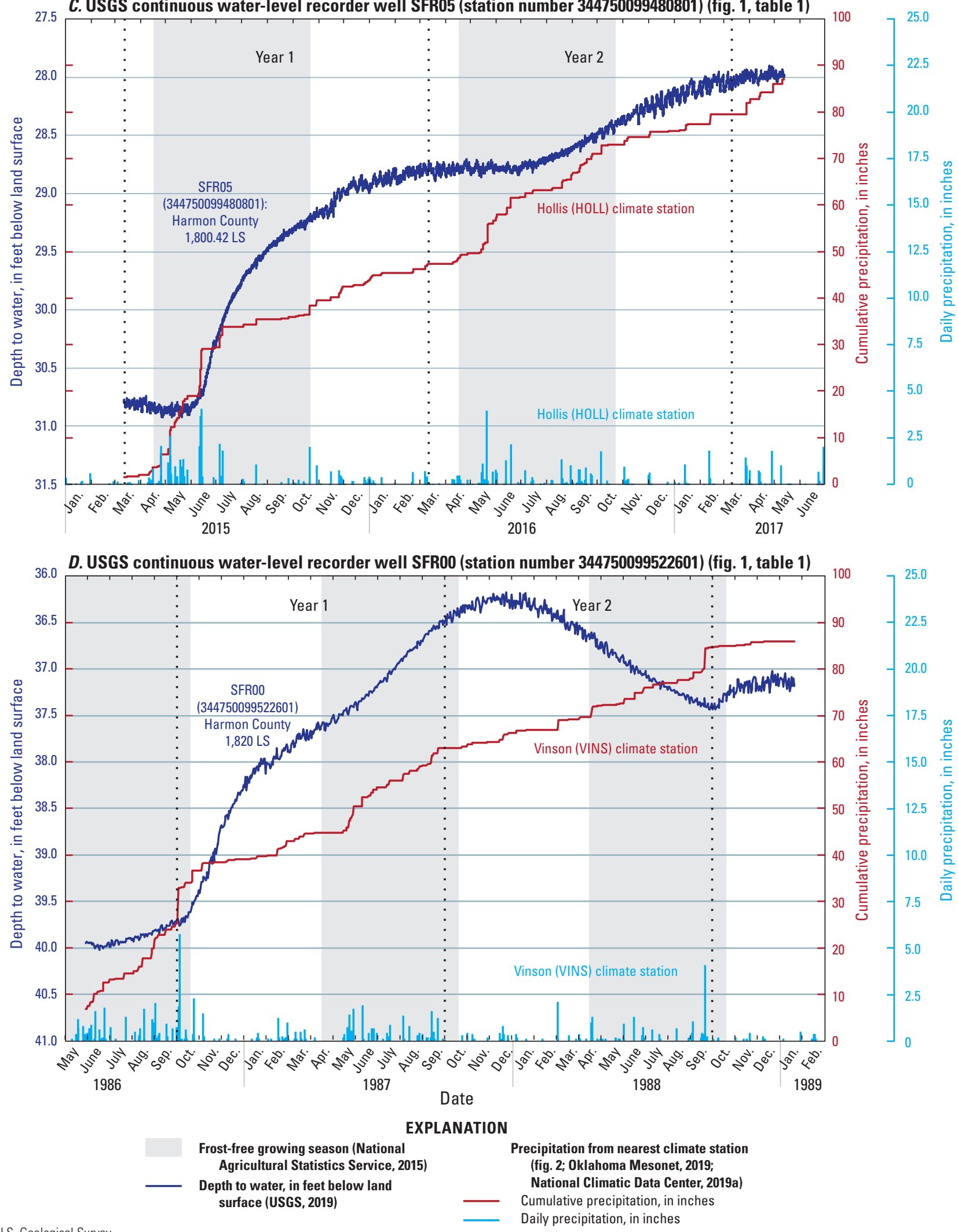

USGS, U.S. Geological Survey

LS, Land surface altitude, in feet above North American Vertical Datum of 1988

Figure 17. Daily and cumulative precipitation and depth to water in continuous water-level recorder wells completed in the Salt Fork Red River aquifer, January 2015-June 2017-Continued 
E. USGS continuous water-level recorder well SFR02 (station number 342835099230401) (fig. 1, table 1)

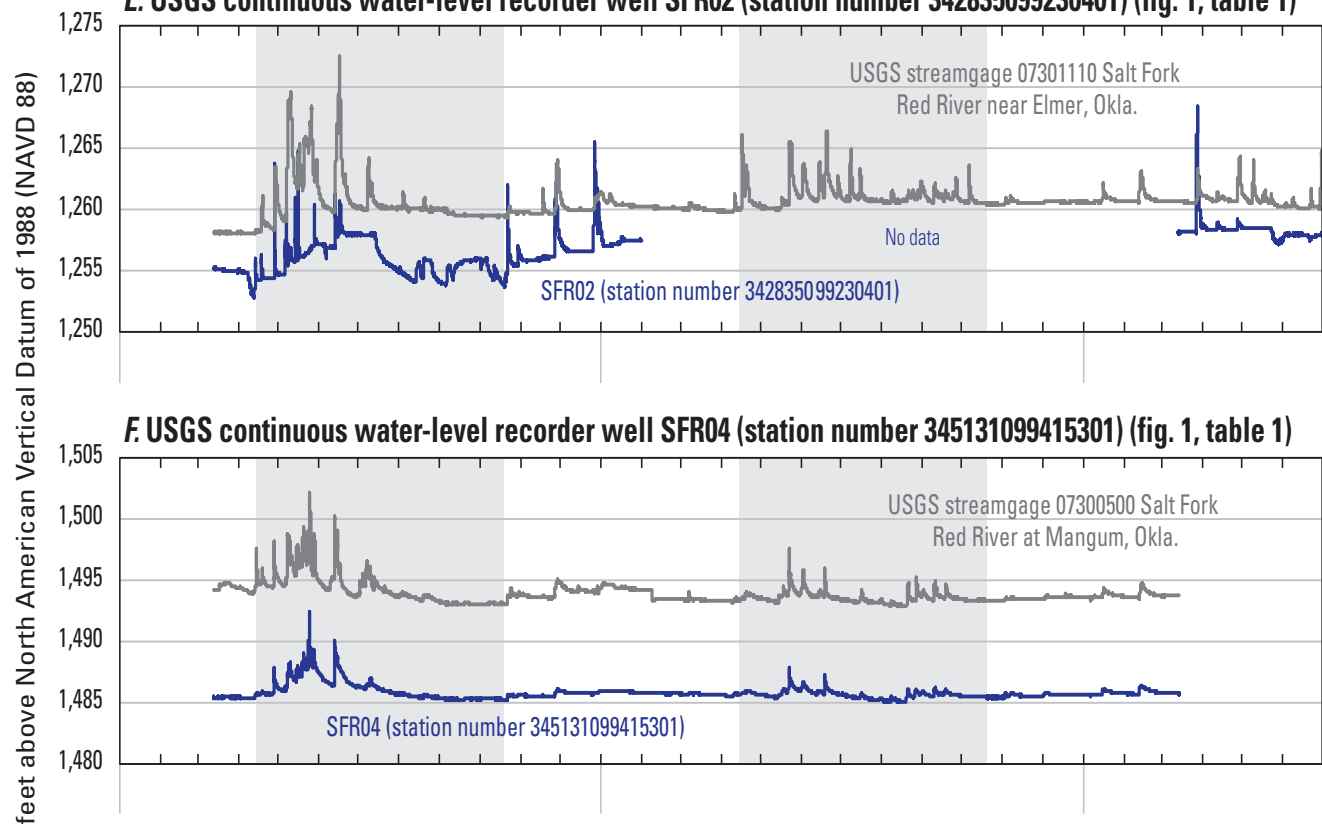

G. USGS continuous water-level recorder well SFR06 (station number 345146099583501) (fig. 1, table 1)

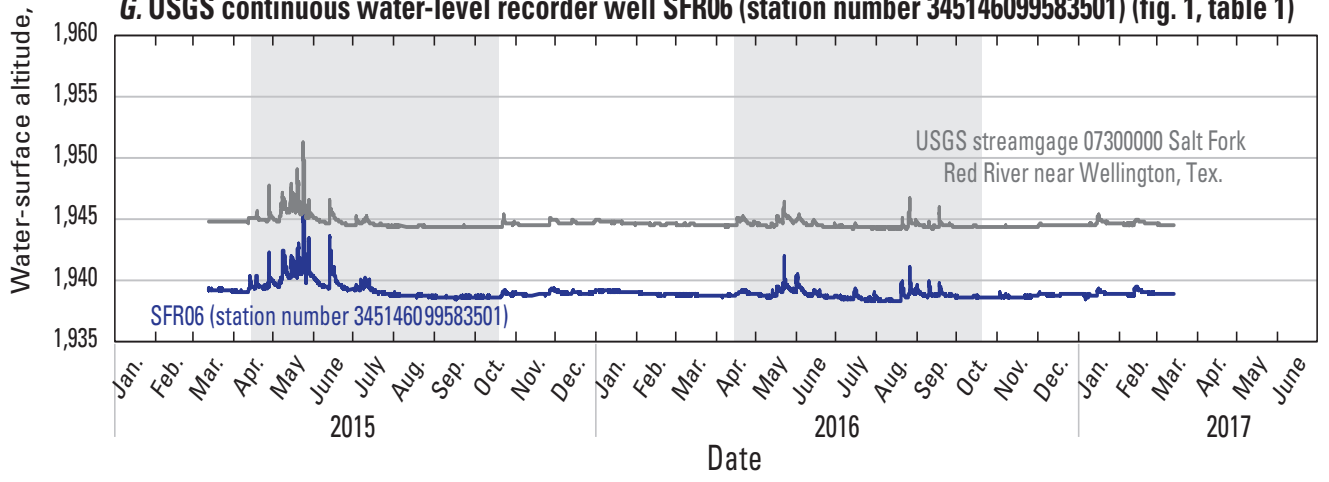

EXPLANATION

Frost-free growing season (National Agricultural Statistics Service, 2015)

Altitude of groundwater level, in feet above NAVD 88 (USGS, 2019)

USGS, U.S. Geological Survey

Stage of Salt Fork Red River, in feet above NAVD 88 (USGS, 2019)

Figure 17. Daily and cumulative precipitation and depth to water in continuous water-level recorder wells completed in the Salt Fork Red River aquifer, January 2015-June 2017-Continued 
Annual recharge was estimated for a 2-year period (starting in October) during 1986-88 at continuous waterlevel recorder well SFR00 and for a 2-year period (starting in March) during 2015-17 at continuous water-level recorder wells SFR01, SFR03, and SFR05 (fig. 1, table 1). When using the daily precipitation record from the nearest climate station and a specific yield of 0.12 , the annual recharge estimates ranged from $0.4 \mathrm{in} / \mathrm{yr}$ (1.7 percent of annual precipitation during 1987-88) to $21.5 \mathrm{in} / \mathrm{yr}$ (44.5 percent of annual precipitation during 2015-16) (table 7). The annual recharge estimates generally increased nonlinearly with increasing precipitation; wet year-long periods had disproportionally greater recharge than dry year-long periods. The mean annual recharge for wells SFR01, SFR03, and SFR05 was $11.5 \mathrm{in} / \mathrm{yr}$ (26.3 percent of annual precipitation [43.6 in/yr]) during 2015-16 and $6.1 \mathrm{in} / \mathrm{yr}$ (17.3 percent of annual precipitation [35.3 in/yr]) during 2016-17 (table 7). When normalized by the mean annual precipitation for the study period, the station-averaged mean recharge was about $4.2 \mathrm{in} / \mathrm{yr}$. All the year-long periods analyzed with the WTF method, however, were wet (annual precipitation exceeded the mean annual precipitation for the study period 1980-2015) except for 1987-88, which was dry (table 7). The station-averaged mean annual recharge calculated by the WTF method, therefore, probably is an overestimation of the mean annual recharge for the study period.

Estimates of mean annual recharge rates for analogous Quaternary-age alluvium and terrace deposits with similar climates in western Oklahoma include 2.3 in/yr (Cimarron River alluvium and terrace deposits; Adams and Bergman, 1996), about 8 percent of mean annual precipitation for that study area; 3.15 in/yr (Tillman terrace deposits; Barclay and Burton, 1953), about 11 percent of mean annual precipitation for that study area; and 1.74 in/yr (Salt Fork Red River alluvium and terrace deposits; Steele and Barclay, 1965), about 7 percent of mean annual precipitation for that study area. The mean annual recharge rate for the North Fork Red River aquifer for the period 1980-2013 was estimated to be about $2.77 \mathrm{in} / \mathrm{yr}$, or 9.5 percent of the mean annual precipitation (29.2 in/yr) for the same period (Smith and others, 2017a). Based on annual recharge percentages estimated from these studies and by using the WTF method, the mean annual recharge rate to the Salt Fork Red River aquifer for the period 1980-2015 was estimated to be about 2.94 in/yr or 10.0 percent of the mean annual precipitation for the same period (29.4 in/yr; table 2). This 1980-2015 mean annual recharge rate of $2.94 \mathrm{in} / \mathrm{yr}(0.25$ feet per year [ft/yr] $)$, multiplied by the aquifer area of 155,929 acres (excluding about 19,764 acres comprising the Mulberry Creek and Horse Creek terraces), is equivalent to a mean annual recharge rate of about 38,000 acre-ft/yr (table 6). The mean annual recharge rates upgradient and downgradient from the Mangum gage, apportioned by aquifer area (41.5 and 58.5 percent, respectively), were about 16,000 and 22,000 acre-ft/yr, respectively (table 6, fig. 16A).

None of the wells used in WTF analysis were in the Lugert-Altus Irrigation District, so the effects of irrigation return flows from the district to the groundwater were not observed or quantified. During the growing season, however, these flows likely add some additional recharge (seepage from unlined laterals and irrigated fields) to the Salt Fork Red River aquifer, primarily in the northeastern part of the Martha terrace between the Salt Fork Red River and Bitter Creek. Of the 7,500 acre-ft/yr that was estimated to irrigate district lands overlying the aquifer, only a small portion (assumed 10-30 percent based on estimates from somewhat comparable settings [Roark and Healy, 1998; Arnold, 2011]) was expected to recharge the aquifer as irrigation return flows. Irrigation return flows from the district, therefore, were thought to be a small to negligible component of recharge and, therefore, were not included in the conceptual-model water budget.

Daily spatially distributed recharge to the Salt Fork Red River aquifer also was simulated for the study period 1980-2015 by using the Soil-Water-Balance code (SWB; Westenbroek and others, 2010). SWB uses a modified Thornthwaite and Mather (1957) soil-water-balance method on a gridded data structure to compute the daily amount of precipitation infiltration that exceeds the storage capacity of the plant root zone and the transpiration demand from plants. The Hargreaves and Samani (1985) method was used to compute evapotranspiration for a reference latitude range of 34.4-34.9 degrees. Selected land-cover and soil properties were used to partition daily precipitation into infiltration and runoff components. Land-cover types from Multi-Resolution Land Characteristics Consortium (2011; Fry and others, 2011) were used to assign runoff curve numbers and plant root-zone depths. The SWB plant root-zone depths for shrubland, grass/ pasture, and crops (the dominant land-cover types overlying the aquifer; fig. 3) varied with soil texture. Soil properties (available water capacity and hydrologic soil group) were derived from the Soil Survey Geographic database (SSURGO; Natural Resources Conservation Service, 2015). Digital elevation models (USGS, 2015) with filled depressions were used to determine the runoff flow direction and route runoff downslope in each SWB grid cell. The SWB grid cell size was 200 by $200 \mathrm{ft}$. The land-cover, soil, and altitude inputs were assumed to remain constant during the study period, but climate data inputs varied daily. Climate data inputs included inverse-distance-weighted (IDW; Esri, Inc., 2017) interpolated grids of daily precipitation, maximum temperature, and minimum temperature from selected climate stations (National Climatic Data Center, 2019a; Oklahoma Mesonet, 2019; Smith and others, 2021) in and near the study area (fig. 2). Infiltration from irrigation in the Lugert-Altus Irrigation District and other irrigated areas was not simulated by SWB.

SWB is a numerical model, and SWB-estimated recharge must, therefore, be checked against and calibrated to the conceptual-model recharge. This calibration was accomplished by adjusting SWB root-zone depths until the SWB-estimated mean annual recharge for the period 1980-2015 was within about 5 percent of the conceptual-model recharge; reducing the root-zone depth results in less soil water evapotranspiring and more water recharging the aquifer. Root-zone depths ranging from 0.8 to $1.5 \mathrm{ft}$ (40 percent of the values used by Westenbroek and others [2010] for permeable glacial deposits 
Table 7. Summary of recharge estimates using the water-table fluctuation method for the Salt Fork Red River aquifer, 1986-88 and 2015-17.

[--, not available or not applicable. Dates in MM-DD-YYYY format. Continuous water-level recorder wells SFR02, SFR04, and SFR06 were not suitable for the water-table fluctuation method because of surface-water influence. Results from wet year-long periods shaded in blue and dry year-long periods shaded in orange]

\begin{tabular}{|c|c|c|c|c|c|}
\hline & \multicolumn{4}{|c|}{ U.S. Geological Survey continuous water-level recorder well (fig. 1; table 1) } & \multirow{2}{*}{ Mean } \\
\hline & SFRO0 & SFR01 & SFR03 & SFR05 & \\
\hline $\begin{array}{l}\text { Mean annual precipitation 1980-2015, in inches, } \\
\text { Southwest Oklahoma, Climate Division } 7 \\
\text { (National Climatic Data Center, 2019b) }\end{array}$ & 29.4 & 29.4 & 29.4 & 29.4 & -- \\
\hline Climate station (fig. 2) & Vinson (VINS) & Altus (ALTU) & Mangum (MAN5) & Hollis (HOLL) & -- \\
\hline Estimated specific yield & 0.12 & 0.12 & 0.12 & 0.12 & -- \\
\hline \multicolumn{6}{|c|}{ Year 1: 10-01-1986 to 09-30-1987 } \\
\hline Annual precipitation, in inches & 37.7 & -- & -- & -- & -- \\
\hline Sum of water-level rises, in feet & 3.3 & -- & -- & -- & -- \\
\hline Recharge, in inches per year & 4.8 & -- & -- & -- & -- \\
\hline Recharge, percent of annual precipitation & 12.6 & -- & -- & -- & -- \\
\hline $\begin{array}{l}\text { Normalized recharge, percent of mean annual } \\
\text { precipitation 1980-2015 }\end{array}$ & 3.7 & -- & -- & -- & 3.7 \\
\hline \multicolumn{6}{|c|}{ Year 2: 10-01-1987 to 09-30-1988 } \\
\hline Annual precipitation, in inches & 21.7 & -- & - & -- & -- \\
\hline Sum of water-level rises, in feet & 0.3 & -- & -- & -- & -- \\
\hline Recharge, in inches per year & 0.4 & -- & -- & -- & -- \\
\hline Recharge, percent of annual precipitation & 1.7 & -- & -- & -- & -- \\
\hline $\begin{array}{l}\text { Normalized recharge, percent of mean annual } \\
\text { precipitation 1980-2015 }\end{array}$ & 0.5 & -- & -- & -- & 0.5 \\
\hline \multicolumn{6}{|c|}{ Year 3: 03-13-2015 to 03-12-2016 } \\
\hline Annual precipitation, in inches & -- & 36.8 & 48.2 & 45.8 & 43.6 \\
\hline Sum of water-level rises, in feet & -- & 6.9 & 14.9 & 2.1 & 8.0 \\
\hline Recharge, in inches per year & -- & 9.9 & 21.5 & 3.0 & 11.5 \\
\hline Recharge, percent of annual precipitation & -- & 27.0 & 44.5 & 6.6 & 26.3 \\
\hline $\begin{array}{l}\text { Normalized recharge, percent of mean annual } \\
\text { precipitation 1980-2015 }\end{array}$ & -- & 7.9 & 13.1 & 1.9 & 7.7 \\
\hline \multicolumn{6}{|c|}{ Year 4: 03-13-2016 to 03-12-2017 } \\
\hline Annual precipitation, in inches & -- & 37.4 & 36.3 & 32.2 & 35.3 \\
\hline Sum of water-level rises, in feet & -- & 4.9 & 6.9 & 0.9 & 4.2 \\
\hline Recharge, in inches per year & -- & 7.1 & 9.9 & 1.3 & 6.1 \\
\hline Recharge, percent of annual precipitation & -- & 18.9 & 27.3 & 4.0 & 17.3 \\
\hline $\begin{array}{l}\text { Normalized recharge, percent of mean annual } \\
\text { precipitation 1980-2015 }\end{array}$ & -- & 5.5 & 8.0 & 1.2 & 4.9 \\
\hline Station-averaged mean annual recharge & & & & & 4.2 \\
\hline
\end{tabular}

in Wisconsin) produced a mean annual recharge rate that nearly matched that of the conceptual model; the initial SWBestimated mean annual recharge for the Salt Fork Red River aquifer study area was $2.92 \mathrm{in} / \mathrm{yr}$ (fig. 18A) or 99 percent of the conceptual-model recharge (2.94 in/yr or 38,225 acre-ft/yr, table 6). The minimum and maximum SWB-estimated annual recharge rates for the period 1980-2015 were about $0.5 \mathrm{in} / \mathrm{yr}$ (2012) and $8.1 \mathrm{in} / \mathrm{yr}$ (2015), respectively (fig. 18A). Spatially, recharge was greatest in areas of active alluvium along the Salt Fork Red River (Qal, fig. 9) and in parts of the terrace deposits
(Qtd, fig. 9) where windblown sand (dune) deposits were more abundant (fig. 19). Mean monthly recharge for the period 1980-2015 was greatest in May and June, when precipitation was greatest. Mean monthly recharge as a percentage of the mean monthly precipitation (recharge efficiency) (fig. 18B) was greatest in the winter months, when evapotranspiration is at a minimum. The SWB model for the Salt Fork Red River aquifer study area is included in Smith and others (2021). 

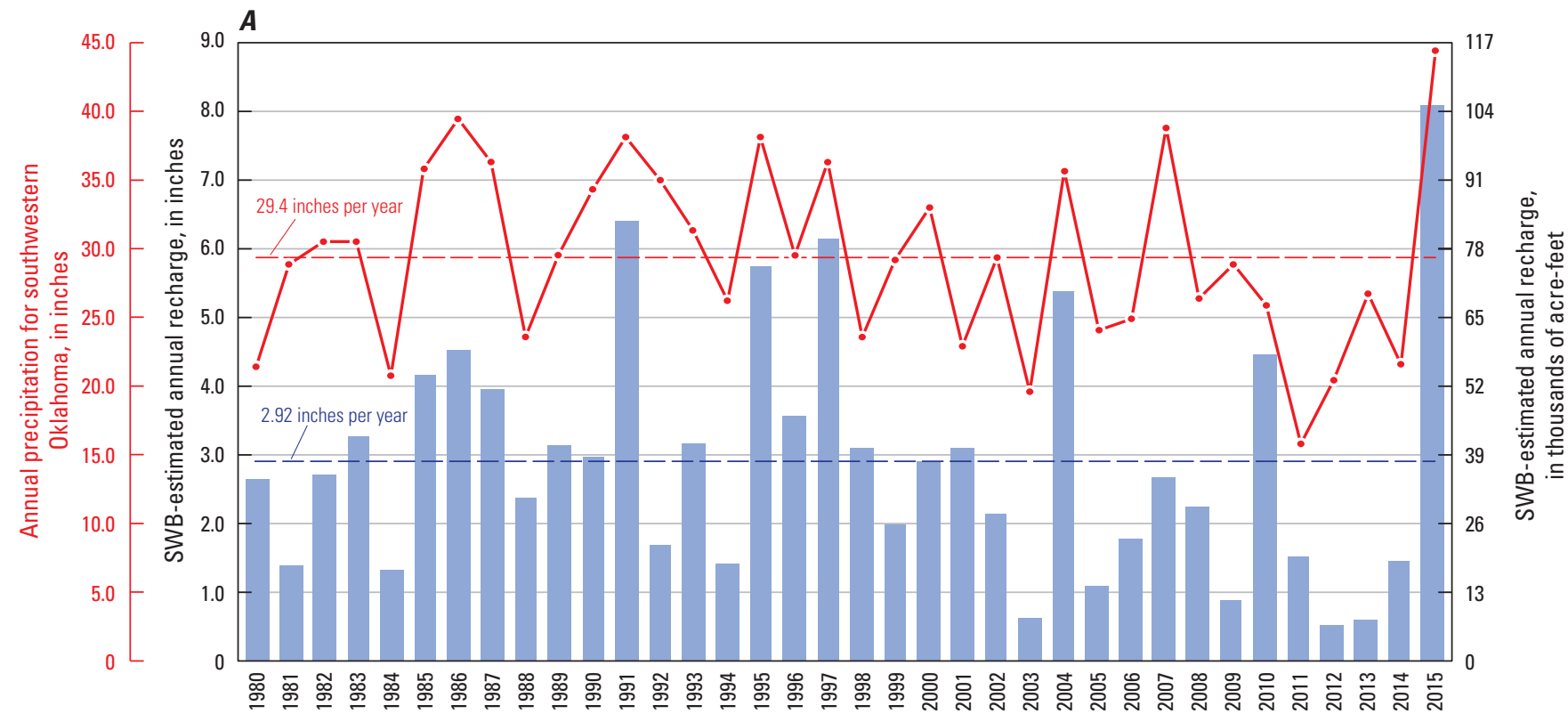

Year
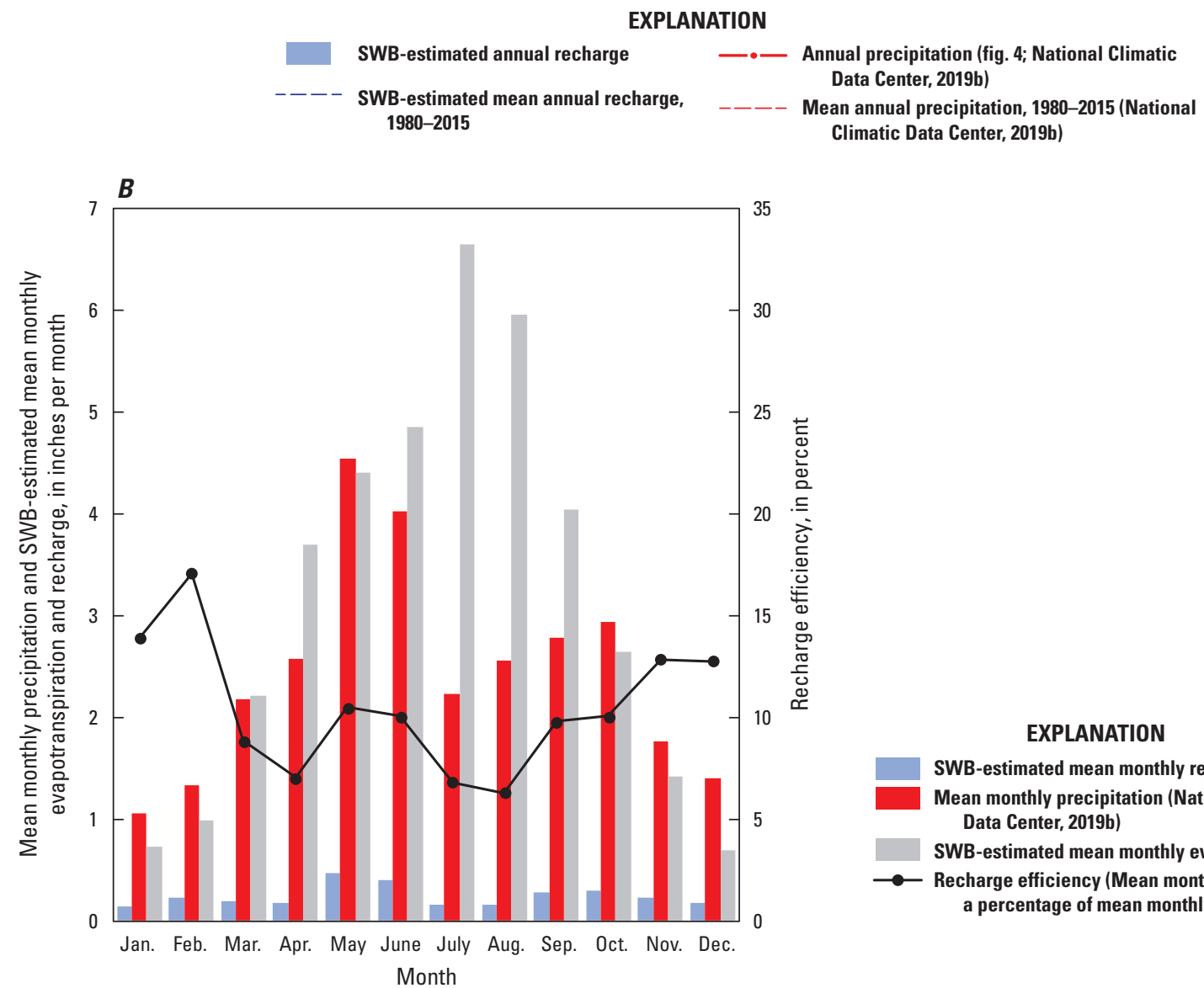

\section{EXPLANATION}

SWB-estimated mean monthly recharge

Mean monthly precipitation (National Climatic Data Center, 2019b)

SWB-estimated mean monthly evapotranspiration

$\multimap-$ Recharge efficiency (Mean monthly recharge as a percentage of mean monthly precipitation)

SWB, Soil-Water-Balance code (Westenbroek and others, 2010)

Figure 18. A, Annual precipitation with annual recharge estimated by using the Soil-Water-Balance code (SWB; Westenbroek and others, 2010); and $B$, mean monthly precipitation with mean monthly recharge and evapotranspiration estimated by using the SWB for the Salt Fork Red River aquifer, southwestern Oklahoma, 1980-2015. 


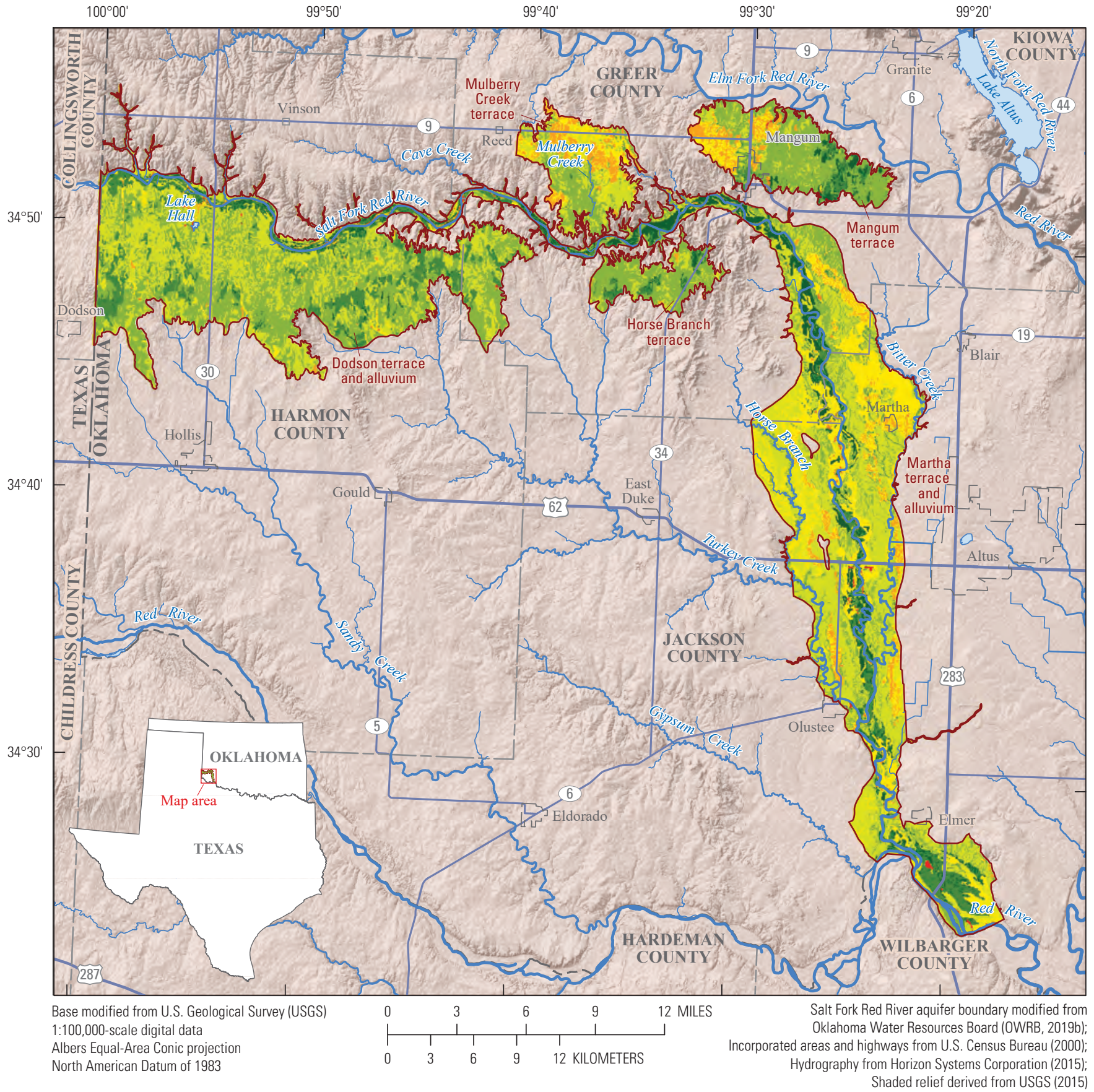

EXPLANATION

Spatially distributed mean annual recharge, in inches, 1980-2015-

Estimated from Soil-Water-Balance code. Recharge was scaled

for use in the numerical groundwater-flow model

0 to 0.30

0.31 to 0.60

0.61 to 1.00

1.01 to 1.50

1.51 to 2.50

2.51 to 4.00

4.01 to 7.00

7.01 to 17.0

Salt Fork Red River aquifer boundary

Figure 19. Mean annual recharge estimated by using the Soil-Water-Balance code (SWB; Westenbroek and others, 2010) for the Salt Fork Red River aquifer, southwestern Oklahoma, 1980-2015. 


\section{Lateral Groundwater Flows}

No data were available to estimate lateral groundwater flows (including vertical groundwater flows) across geologic and political boundaries of the Salt Fork Red River aquifer. The alluvium and terrace deposits (Seymour aquifer) in Collingsworth County, Tex. (figs. 1 and 9), which are adjacent to and upgradient from the deposits of the Salt Fork Red River, likely contributed lateral groundwater flows (net inflows) to the Salt Fork Red River aquifer. Likewise, the Salt Fork Red River aquifer likely contributed lateral groundwater flows (net outflows) to the adjacent and downgradient alluvium and terrace deposits (Seymour aquifer) along the Red River. Lateral groundwater flows between the Salt Fork Red River aquifer and most of the underlying and adjacent bedrock units of Permian age were assumed to be a negligible component of the conceptual model because of the relatively low hydraulic conductivities of the Permian-age bedrock, especially in the eastern part of the study area. However, the Blaine Formation of Permian age, which directly underlies and abuts the Salt Fork Red River alluvium between Mangum and central Harmon County, has locally developed karst features (sinkholes and disappearing streams) and probably exchanges lateral groundwater flows with the aquifer. These flows were likely to be net outflows but are expected to account for a small component of the conceptual model because (1) the area over which the Blaine Formation contacts the Salt Fork Red River aquifer is small and (2) synoptic streamflow (seepage-run) measurements did not show a strong and temporally persistent loss of base flow in that reach of the Salt Fork Red River (figs. 20A-C). For these reasons, and because continuous groundwater-level measurements were not available near these boundaries, lateral groundwater flows were assumed (on the basis of published conceptual models from similar aquifers in western Oklahoma) to be small, with an estimated net outflow from the aquifer totaling about 3 percent of the water budget $(1,200 \mathrm{acre}-\mathrm{ft} / \mathrm{yr})$.

\section{Streambed Seepage}

Base flow can be measured directly in streams when the runoff component of streamflow is at or near zero. When baseflow measurements are collected at multiple locations over a short span of time, they are called synoptic base-flow (seepagerun) measurements. These measurements can be used to calculate net streambed seepage and classify stream reaches as gaining (exhibiting an increase in base flow between the upstream and downstream endpoints of the reach) or losing (exhibiting a decrease in base flow between the upstream and downstream endpoints of the reach). Synoptic base-flow measurements presented in this report (USGS, 2019) were collected by using the methods of Rantz and others (1982); streambed-seepage rates were calculated as the difference in measured base flows (adjusted for tributary inflows) divided by the stream-reach length between measurement locations.

Three sets of synoptic base-flow measurements were used to calculate streambed seepage for the Salt Fork Red River (figs. 20A-C). Synoptic base-flow measurements during February 16-18, 1988, were collected in support of a study of the Blaine aquifer (fig. 20A; Runkle and others, 1997). In February 1988, most of the Salt Fork Red River in the study area was gaining, but the reach upstream from State Highway 30 was losing. Because these measurements were collected during one of the wettest periods on record (fig. 4A), they probably captured unusually large base-flow and streambed-seepage (gaining) conditions. Most of the February 1988 synoptic baseflow measurements were on tributaries rather than on the Salt Fork Red River. These tributary measurements show that most Salt Fork Red River tributaries (excluding Turkey Creek, Horse Branch, and Bitter Creek) contributed base flows of less than 2 ft $3 /$ s during February 1988 (fig. 20A). The tributary base-flow measurements were each relatively small, but they indicate that the cumulative contribution of tributary base flows in the Salt Fork Red River may not be negligible during prolonged wet periods.

Additional synoptic base-flow measurements (USGS, 2019; sites not listed in table 1; instead, site information is available in Smith and others [2021]) were collected during March 9-12, 2015, and during February 29-March 2, 2016, in support of this study (figs. 20B, C). The March 2015 measurements were collected following a prolonged drought (figs. $4 A-C$ ) and, therefore, probably captured unusually small base-flow and streambed-seepage (losing) conditions. In March 2015, the Salt Fork Red River alternated between gaining and losing reaches upstream from Reed, Okla., but was mostly losing between Reed and Olustee (fig. 20B). In fact, much of the Salt Fork Red River had no flow between Martha and Olustee in March 2015. The February-March 2016 measurements, which may be most representative of mean base-flow conditions during the study period 1980-2015, show that the Salt Fork Red River had alternating gaining and losing reaches in the study area. The Salt Fork Red River was most strongly gaining (6.47 cubic feet per second per mile) in a short reach west of Altus and was also strongly gaining (4.30 cubic feet per second per mile) just east of the Texas border (fig. 20C). The Salt Fork Red River was most strongly losing $(-3.67$ cubic feet per second per mile) in a reach downstream from Mulberry Creek in Greer County and was also strongly losing ( -3.15 cubic feet per second per mile) south of Vinson. Most tributaries that originated outside the boundaries of the Salt Fork Red River aquifer were dry or carried negligible base flows (less than $1 \mathrm{ft} 3 / \mathrm{s}$ ) during March 2015 and FebruaryMarch 2016 on the basis of observations by field hydrographers; Turkey Creek and Bitter Creek were the only tributaries carrying base flows large enough to be measured using the methods of Rantz and others (1982) (figs. 20B, C). Streambedseepage data from March 2015 and February-March 2016 indicate that (1) few reaches of the Salt Fork Red River were consistently losing or gaining between 2015 and 2016 and (2) adjacent reaches frequently alternate between losing and gaining, possibly as a result of differences in local groundwater use and saturated-zone evapotranspiration. A few reaches of the Salt Fork Red River were gaining in 2015 and 2016. One of these reaches is just east of the Texas border near the thickest aquifer deposits, and another is just downstream from the confluence with Turkey Creek where the alluvial valley is constricted by small bluffs (figs. 20B, C). 

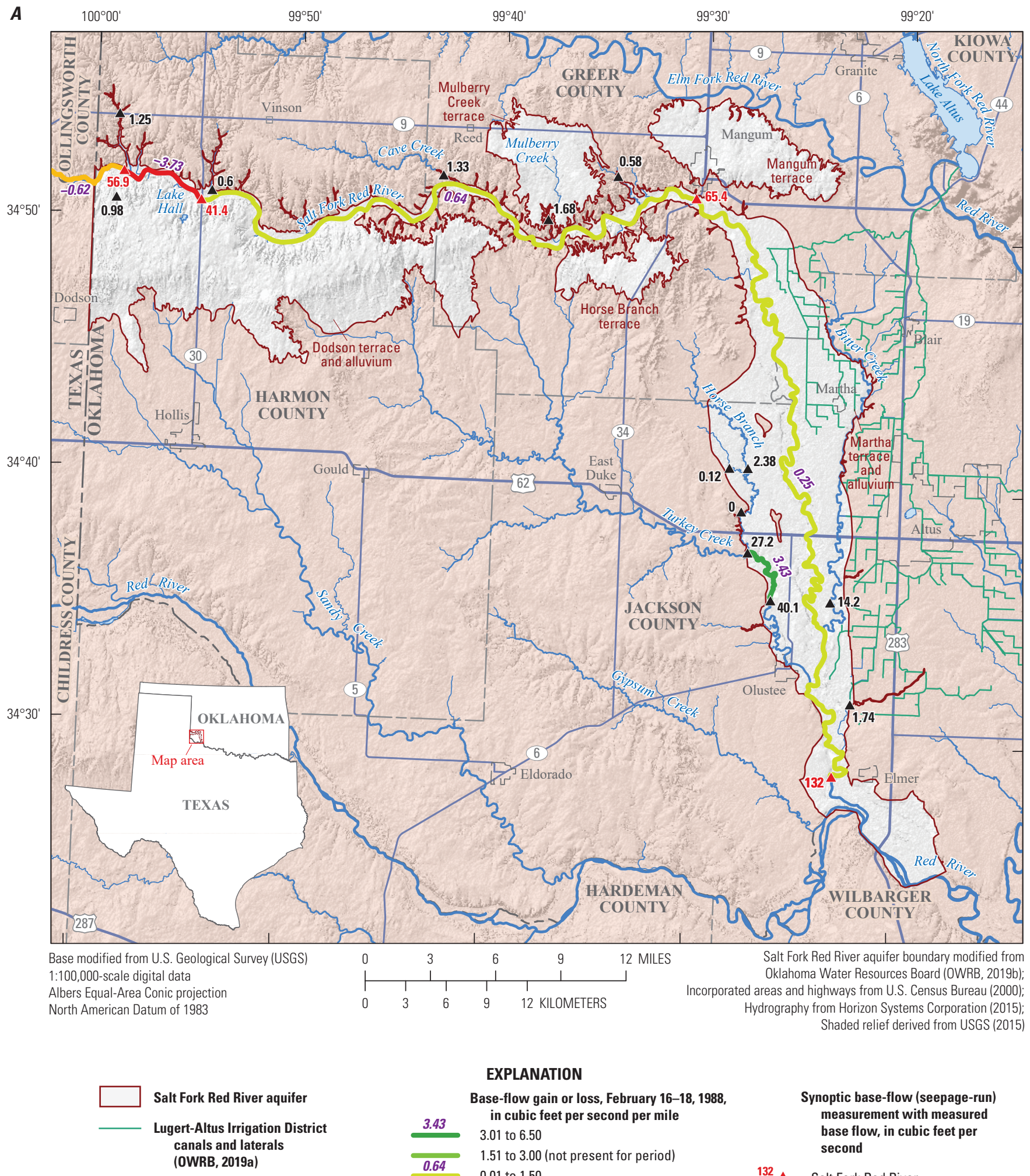

\section{EXPLANATION}

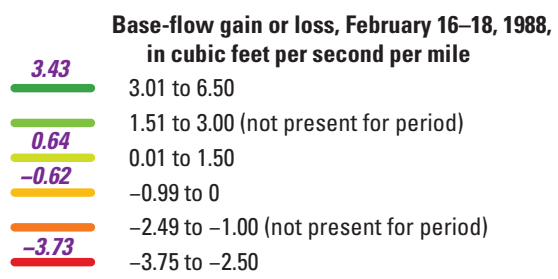

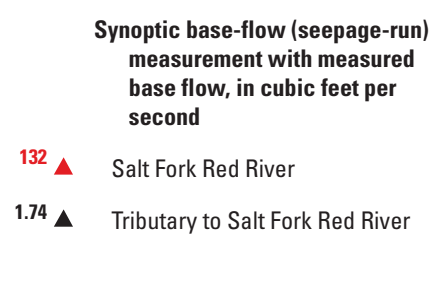

Figure 20. Synoptic streamflow (base-flow) measurements and estimated streambed seepage in gaining and losing reaches of the Salt Fork Red River aquifer, southwestern Oklahoma, during A, February 16-18, 1988; B, March 9-12, 2015; and C, February 29-March 2, 2016. 


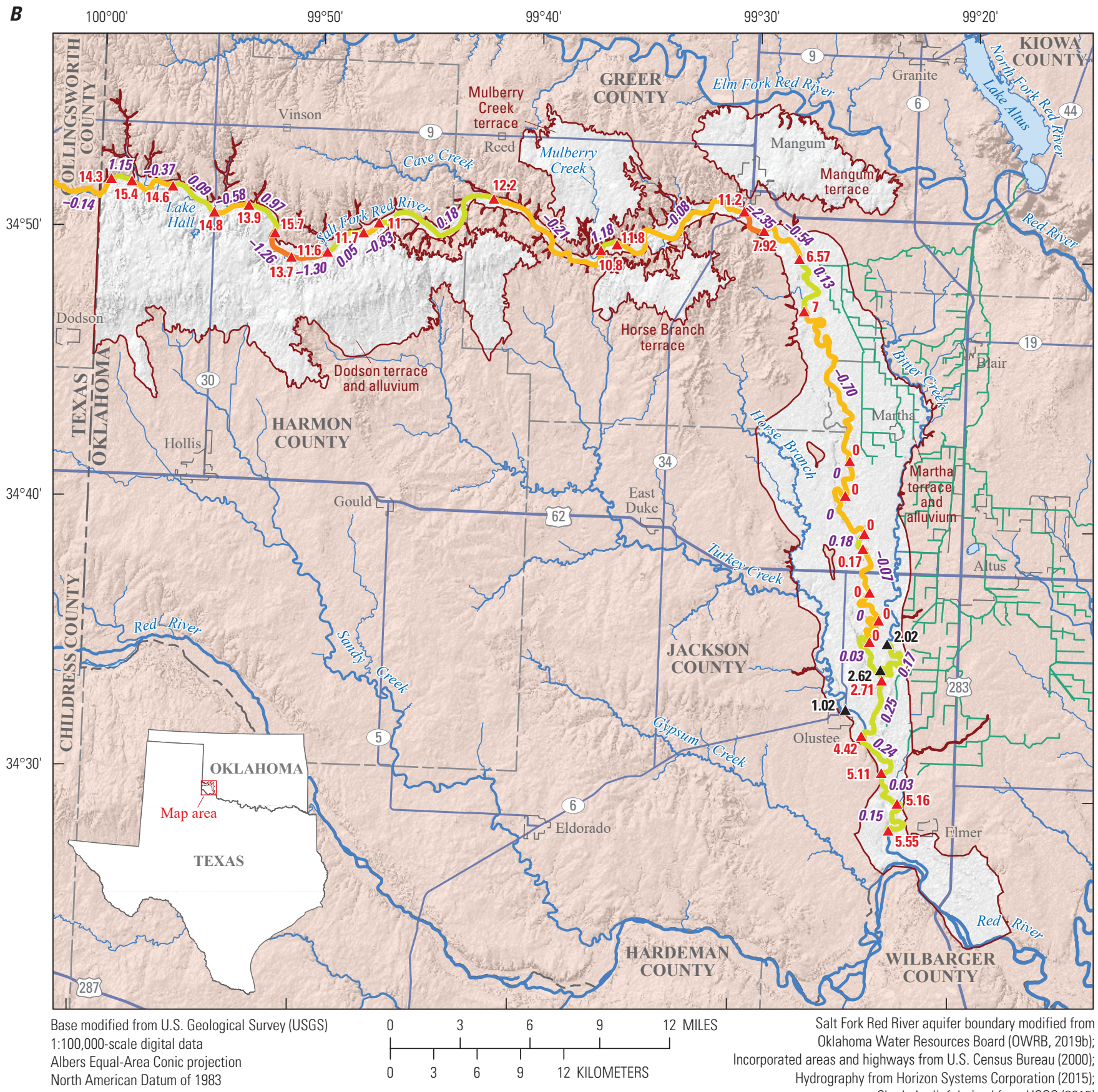

Shaded relief derived from USGS (2015)

Salt Fork Red River aquifer

Lugert-Altus Irrigation District canals and laterals (OWRB, 2019a)

\section{EXPLANATION}

Base-flow gain or loss, March 9-12, 2015, in cubic feet per second per mile

\begin{tabular}{|c|c|}
\hline & 50 (not present fo \\
\hline 0.13 & 1.51 to 3.00 (not present fo \\
\hline-0.21 & 0.01 to 1.50 \\
\hline-2.35 & -2.49 to -1.00 \\
\hline & -3.75 to -2.50 (not present for perioc \\
\hline
\end{tabular}

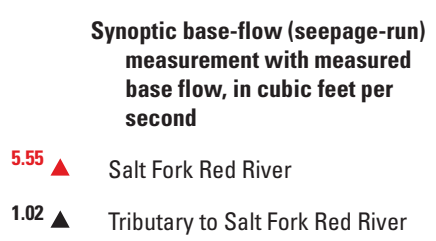

ynoptic base-flow (seepage-run) measurement with measured base flow, in cubic feet per

Salt Fork Red River

$1.02 \triangle$ Tributary to Salt Fork Red River

Figure 20. Synoptic streamflow (base-flow) measurements and estimated streambed seepage in gaining and losing reaches of the Salt Fork Red River aquifer, southwestern Oklahoma, during A, February 16-18, 1988; B, March 9-12, 2015; and C, February 29-March 2, 2016.-Continued 

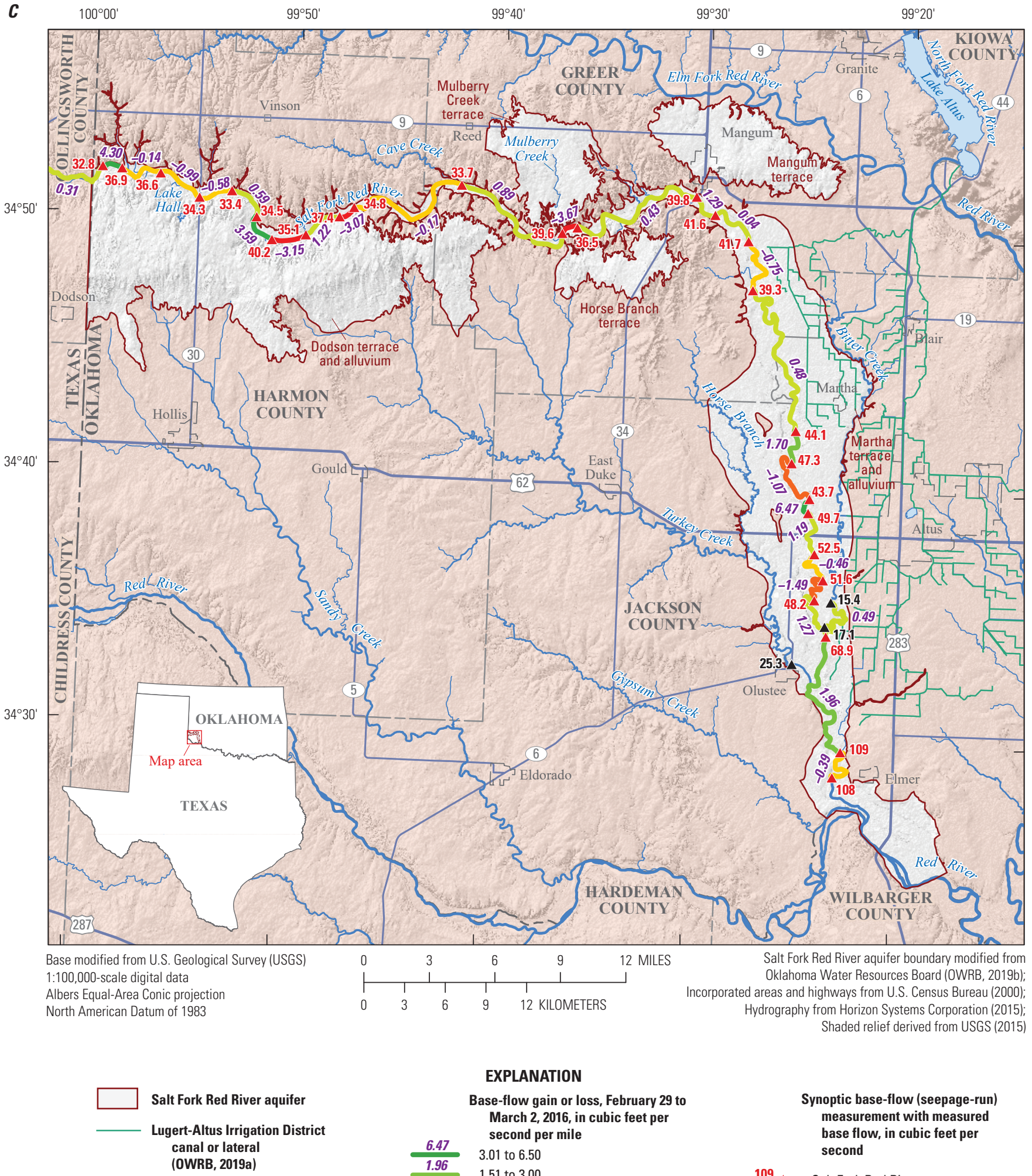

\section{EXPLANATION}

Base-flow gain or loss, February 29 to

March 2, 2016, in cubic feet per

second per mile

$\begin{array}{r}\hline 6.47 \\ \hline 1.96 \\ \hline 0.48 \\ \hline-0.46 \\ \hline-1.07 \\ \hline-3.67 \\ \hline\end{array}$
3.01 to 6.50

1.51 to 3.00

0.01 to 1.50

-0.99 to 0

-2.49 to -1.00

-3.75 to -2.50

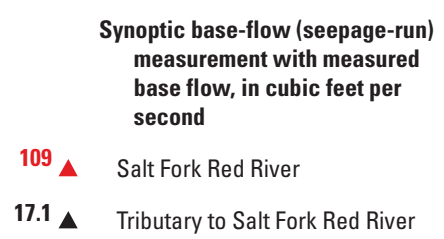

ynoptic base-flow (seepage-run) measurement with measured base flow, in cubic feet per second

17.1 Tributary to Salt Fork Red River

Figure 20. Synoptic streamflow (base-flow) measurements and estimated streambed seepage in gaining and losing reaches of the Salt Fork Red River aquifer, southwestern Oklahoma, during A, February 16-18, 1988; B, March 9-12, 2015; and C, February 29-March 2, 2016.-Continued 
Net streambed-seepage terms for the conceptual model were assumed to be net outflows from the aquifer and were estimated from mean annual base flows computed by using BFI (table 4). Net streambed seepage upgradient from the Mangum gage for the period 1980-2015 (8,181 acre-ft/yr, table 6) was roughly estimated as the mean annual base flow at the Mangum gage minus the mean annual base flow at the Wellington gage (table 4); no attempt was made to adjust (reduce) this value to account for the distance between the Wellington streamgage and the study area boundary along the Oklahoma-Texas border. Net streambed seepage downgradient from the Mangum gage for the period 1980-2015 $(15,320 \mathrm{acre}-\mathrm{ft} / \mathrm{yr}$, table 6$)$ was estimated as the mean annual base flow at the Elmer gage minus the mean annual base flows at the Mangum gage, USGS streamgage 07300530 Bitter Creek near Martha, Okla. (hereinafter referred to as the "Martha gage"), and USGS streamgage 07299670 Groesbeck Creek at State Highway 6 near Quanah, Tex. (hereinafter referred to as the "Quanah gage") (fig. 2, table 4). The Quanah gage on Groesbeck Creek was used as a substitute for USGS streamgage 07301100 Turkey Creek at Olustee, Okla. (hereinafter referred to as the "Olustee gage") because the Quanah gage had a period of record spanning the whole study period 1980-2015; Groesbeck Creek is less than 5 miles south of the study area (fig. 2) and drains a basin that is comparable to that of Turkey Creek at the Olustee gage in terms of shape, orientation, geology, land cover, and drainage area.

\section{Springs and Seeps}

Springs (point discharges of groundwater to the land surface) and seeps (distributed discharges of groundwater to the land surface) are common in the study area, especially on the borders of the high terrace deposits of the Dodson and Mangum terraces, where abrupt changes in permeability of geologic units may occur. Steele and Barclay (1965) noted several springs in the study area, but most have since ceased flowing perennially or have greatly reduced flows as observed during recent synoptic streamflow field trips (March 2015 and February-March 2016). The largest historically documented springs were located on the north side of the Dodson terrace. A complex of springs near the Texas border (fig. 14) historically produced more than $240 \mathrm{gal} / \mathrm{min}(0.5 \mathrm{ft} 3 / \mathrm{s})$, and a complex of springs (now inundated) just west of Oklahoma State Highway 30 historically produced more than $360 \mathrm{gal} / \mathrm{min}(0.8 \mathrm{ft} 3 / \mathrm{s}$; Steele and Barclay, 1965). The latter complex of springs still produces enough flow to partially sustain a 36-acre reservoir that holds 560 acre-ft of water (Lake Hall, fig. 14; OWRB [2020a]). A complex of springs just east of Oklahoma State Highway 30 (Hollis Spring, fig. 14) provided all water supplied to Hollis, Okla., until 1948 when the springs were supplemented by wells in the same area (Steele and Barclay, 1965). Other small springs and seeps (not shown in fig. 14) originating from the terrace deposits and primarily used for livestock also were documented along the northern boundary of the Mangum terrace and along Mulberry Creek (Steele and Barclay, 1965).
Groundwater outflow to distributed springs and seeps is difficult to estimate at the spatial and temporal scale of this investigation, and no systematic measurements of spring discharge were available in the study area. Smith and others (2017a) estimated that outflow to springs and seeps in the North Fork Red River aquifer was less than 10 percent of net streambed seepage in that aquifer. That estimate was increased proportionally for the Salt Fork Red River aquifer because the Salt Fork Red River aquifer has a larger area of springs and seeps as compared to that of the North Fork Red River aquifer. Groundwater outflow to springs and seeps in the Salt Fork Red River aquifer, therefore, was assumed (on the basis of published conceptual models from similar aquifers in western Oklahoma) to be about 15 percent of net streambed seepage or about 3,500 acre-ft/yr (table 6).

\section{Saturated-Zone Evapotranspiration}

Evapotranspiration is the process by which water is transferred to the atmosphere directly through evaporation and indirectly through plant transpiration. Much of this process, however, occurs at the land surface where precipitation pools as surface water or where it infiltrates the soil unsaturated zone and becomes available to plant root zones (Lubczynski, 2008). These surface-water and unsaturated-zone components of evapotranspiration were not considered to be a part of the conceptual model for the Salt Fork Red River aquifer because they occur before infiltrating precipitation has reached the saturated zone to become groundwater recharge. A supplementary component of evapotranspiration, however, occurs in areas of the aquifer where the saturated zone intersects the plant root zone, most commonly in lower lying or wetland areas along streams (Lubczynski, 2008); this component of evapotranspiration (hereinafter called "saturated-zone evapotranspiration") was an important part of the conceptual-model water budget.

Rates of saturated-zone evapotranspiration are difficult to estimate over a large area but are expected to be roughly proportional to (1) the area where the saturated zone intersects the plant root zone, (2) the mean depth to groundwater in that area during the growing season, and (3) the mean rate of transpiration associated with the assemblage of plants in that area. The area where the saturated zone intersects the plant root zone probably is small compared to the entire aquifer area and is mostly confined to the nearly perennial Salt Fork Red River stream corridor. About 15,000 acres along the Salt Fork Red River stream corridor were classified as wetland (land area with frequently saturated or flooded soils [Cowardin and others, 1979] including riverine wetlands, freshwater emergent wetlands, and freshwater forested/shrub wetlands) by the National Wetlands Inventory (NWI; U.S. Fish and Wildlife Service, 2015). Much of the area classified as wetlands, however, lacked vegetation or had a land surface (and presumed water table) with relatively steep slopes according to aerial photographs and DEM inspection in 2020. Therefore, only about half (7,500 acres) of the NWI wetland area was assumed 
to contribute to saturated-zone evapotranspiration. The saturated-zone component of evapotranspiration was assumed to be active during the growing season (April-October [National Agricultural Statistics Service, 2015; Oklahoma Climatological Survey, 2015]), greatest annually in wet and hot years, and greatest monthly in early summer (Scholl and others, 2005) when precipitation and temperature are above their mean values (figs. $5 A, B$ ).

By using the assumptions listed, groundwater outflow by saturated-zone evapotranspiration could be estimated from daily water-level fluctuation data at wells with shallow depths to water according to methods of White (1932). Wells with continuously measured groundwater-level data were not available in the study area, but gage-height data from the Mangum and Elmer gages indicated daily declines in stream stage during daylight hours in summer low-flow conditions. These daily declines in stream stage (with rebounds at night) indicated that saturated-zone evapotranspiration was an active process in the Salt Fork Red River aquifer, but the declines were too small to be accurately measured from the gage-height data. For this reason, the White (1932) methods were not used. White (1932), however, estimated annual saturated-zone evapotranspiration rates of $0.75-1.9 \mathrm{ft} / \mathrm{yr}$ for undisturbed salt grass cover in southwestern Utah with a mean depth to water of 1-2 ft. Evapotranspiration rates in southwestern Utah, where relative humidity and dewpoint temperature are comparatively low (National Climatic Data Center, 2019a), are likely greater than evapotranspiration rates in southwestern Oklahoma; therefore, an annual saturated-zone evapotranspiration rate of about $1.0 \mathrm{ft} / \mathrm{yr}$ was assumed to be appropriate for the Salt Fork Red River. If about 7,500 acres of wetland area had similar cover and depths to water, this assumed rate would correspond to an annual saturated-zone evapotranspiration outflow of 7,500 acre-ft/yr (table 6). This estimated annual saturated-zone evapotranspiration was allocated upgradient and downgradient from the Mangum gage in proportion to aquifer area.

\section{Well Withdrawals, Water-Level Response, and Storage Change}

Mean annual well withdrawals were assumed to equal the mean annual reported groundwater use for the period 1980-2015, or 3,532.7 acre-ft/yr (table 3). About 69 percent of the annual well withdrawals for that period were from permitted wells downgradient from the Mangum gage. Well withdrawals were greatest in dry and hot years because more water was required in those years to grow healthy crops. The water table generally falls during dry and hot years (especially during extended droughts) and rises during wet and cool years (figs. $4 A-C$ ). The degree to which the water table fluctuates annually at a location is related in part to the volume of nearby well withdrawals and the distribution (or concentration) of recharge near that location.

No wells with annual water-level measurements during the entire study period 1980-2015 were available for the Salt Fork Red River aquifer, so estimating net storage change in the Salt Fork Red River aquifer was impossible. However, the OWRB (2019a) Mass Measurement Program recorded annual water-level measurements (usually in winter) from wells 9436 and 9497 (fig. 1) completed in the underlying Blaine aquifer. Those measurements show a general rise in water-level altitudes during the cooler and wetter early period (1980-98) and a general decline in water-level altitudes during the hotter and drier late period (1999-2014) (figs. 4A-C). The same patterns of changes in water-level altitudes, but with smaller magnitudes, were expected for the Salt Fork Red River aquifer; OWRB (2019a) wells 9437 (completed in the Salt Fork Red River aquifer and in the Blaine aquifer) and 9442 (completed only in the Salt Fork Red River aquifer) show more muted changes in water-level altitudes as compared to wells 9436 and 9497 (completed only in the Blaine aquifer) (fig. 4C). Because water-table altitudes in the Blaine aquifer at the beginning of the study period 1980-2015 were comparable to those at the end of the study period, the net storage change of the Salt Fork Red River aquifer was assumed to be a negligible component of the conceptual-model water budget. Without the water-table-altitude rebound of 2015 (an unusually wet year), though, the net storage change during the study period likely would have been positive; loss of groundwater storage is reported as a positive aquifer inflow for mass balance purposes.

\section{Conceptual-Model Water Budget}

The conceptual-model water budget (table 6) summarized mean water flows exchanged between each hydrologic boundary and the Salt Fork Red River aquifer for the study period 1980-2015. The components of the water budget were estimated from analyses of available data or assumed on the basis of published analogs as described in the "Hydrologic Boundaries" section. Recharge accounts for 100 percent of the conceptual-model inflows to the Salt Fork Red River aquifer, and net streambed seepage accounts for 59.9 percent of the outflows from the Salt Fork Red River aquifer. Saturated-zone evapotranspiration (19.1 percent of outflows) was the only other component estimated to be greater than 10 percent of inflows or outflows. Well withdrawals accounted for 9.0 percent of conceptual-model outflows. 


\section{Numerical Groundwater-Flow Model}

A finite-difference numerical model of the Salt Fork Red River aquifer was constructed by using MODFLOW-2005 (Harbaugh, 2005) with the Newton formulation solver (MODFLOW-NWT; Niswonger and others, 2011) for improved solution of problems involving drying and rewetting. In the modular design of MODFLOW, each hydrologic boundary of the conceptual model, such as streambed seepage, recharge, or well withdrawals, is included as a boundarycondition package that, when activated, adds new inflow and outflow terms to the groundwater-flow equation being solved. Data inputs for each package are specified in machinereadable text files. Model space is discretized into cells, and the cell size is the finest resolution at which spatially varying properties (such as land-surface altitude or horizontal hydraulic conductivity) may be represented and varied. Model time is discretized into time steps within stress periods. The stress period length is the finest resolution at which temporally varying inflows and outflows may be represented and varied, and the time step length is the finest length of time for which model outputs may be written. Selected numerical-model input values were adjusted to calibrate the model to available water-table-altitude and base-flow observations. The calibrated numerical groundwater-flow model inputs, outputs, metadata, directions for use, and ancillary data were published in a USGS data release (Smith and others, 2021).

\section{Spatial and Temporal Discretization}

The model domain (fig. 21) of the Salt Fork Red River aquifer was spatially discretized into 1,050 rows, 1,125 columns, about 170,000 active cells measuring 200 by $200 \mathrm{ft}$, and a single convertible layer based on the hydrogeologic framework described in this report. Because the model had only one layer, it simulated only 2-dimensional (horizontal) flow between cells. The cell size was chosen to minimize modelprocessing time while still representing the variability of properties being simulated. The chosen cell size also ensured that the narrowest parts of the aquifer were represented by no fewer than five cells; model instability and water-level volatility are common in narrow aquifer areas where groundwater flow is focused into just a few cells. The single convertible layer represented the undifferentiated Quaternary-age alluvium and terrace deposits with variable thickness determined from the hydrogeologic framework; the underlying Permian-age bedrock was not represented as a layer. The altitude of the top of the aquifer was multiplied by 1.001 in the numerical model to prevent confined aquifer conditions that occur as a side effect of model discretization when the simulated water-table altitude slightly exceeds the altitude of the top of the aquifer.
The active modeled area (fig. 21) was initially derived from the Salt Fork Red River aquifer extent (modified from OWRB [2019b]) as defined in the hydrogeologic framework. The active modeled area was further modified during model testing to improve model calibration and stability. First, the active modeled area was expanded or contracted in some areas to ensure that each active cell was in connection with at least one other active cell. Second, the Mulberry Creek terrace and Horse Branch terrace were excluded from the active modeled area because they were (1) relatively small, (2) separated spatially and hydraulically from the rest of the Salt Fork Red River aquifer, (3) mostly devoid of water-level measurements during the study period that could be used in calibration, and (4) mostly unsaturated when water-level measurements were collected in March 2016. The Mangum terrace was retained in the active modeled area but was fully disconnected from the rest of the active modeled area. Thus, the active modeled area is made up of two parts that have no hydraulic connection and, therefore, function as two independent models that are solved simultaneously.

The numerical model was temporally discretized into 432 monthly transient stress periods (each with two time steps to improve model stability) representing the period 1980-2015. An initial steady-state stress period, in which the groundwater-flow equation had no storage component, represented mean annual inflows to, and outflows from, the aquifer and produced a solution that was used as the initial condition for subsequent transient stress periods as well as some groundwater-availability scenarios. The numerical model was constructed by using length and time units of feet and days, respectively.

\section{Simulation of Hydrologic Boundaries and Hydraulic Parameters}

Hydrologic boundaries in the numerical model (fig. 21) define where and how water may enter or leave the model and include specified-flux and head-dependent boundaries (Harbaugh and others, 2000). Specified-flux boundaries were used to simulate recharge and well withdrawals. Headdependent boundaries were used to simulate streambed seepage, saturated-zone evapotranspiration, springs and seeps, and lateral groundwater flow exchanged with adjacent alluvium and terrace deposits across the Texas border and with the Blaine aquifer. When available, hydrologic data (along with data-based assumptions and analogues) were used to estimate or constrain precalibration model inputs for each hydrologic boundary. 


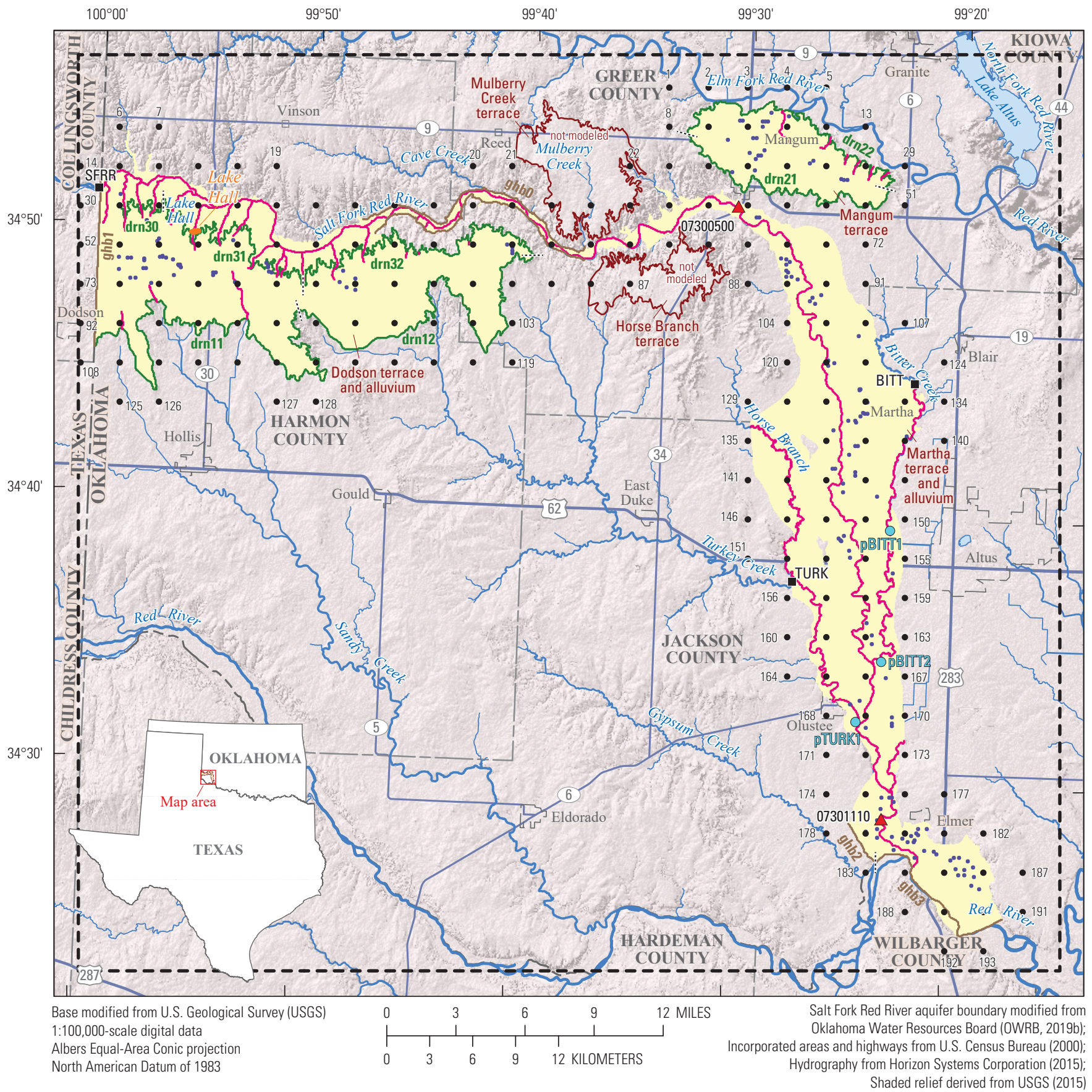

EXPLANATION
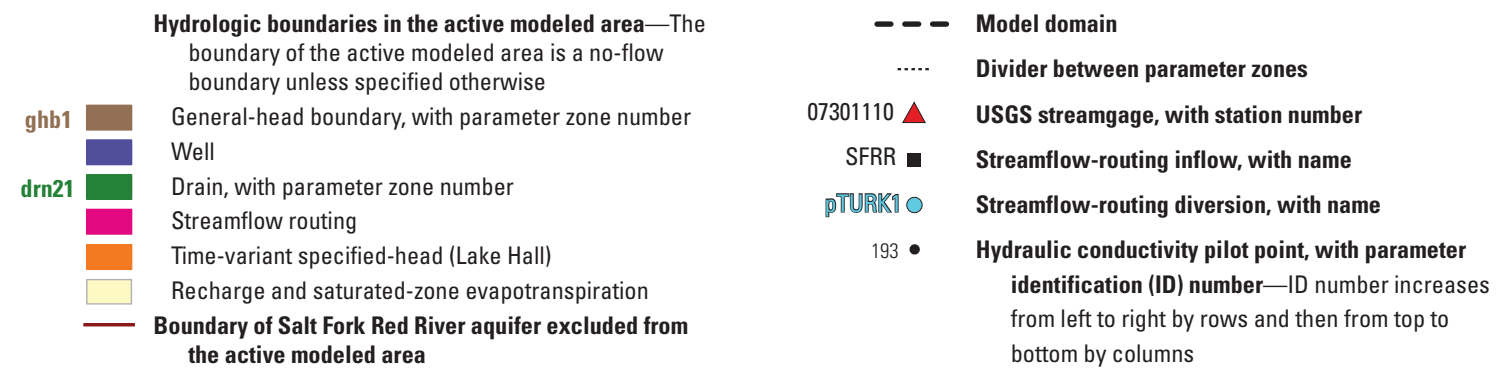

Figure 21. Model domain, active modeled area, hydrologic boundaries, and parameter zones for the numerical groundwater-flow model of the Salt Fork Red River aquifer, southwestern Oklahoma. 


\section{Recharge and Distribution with the Soil-Water-Balance Code}

Recharge to the Salt Fork Red River aquifer was simulated by using the Recharge package (Harbaugh and others, 2000). Recharge was spatially and temporally distributed for each month of the study period 1980-2015 by using the SWB code (Westenbroek and others, 2010).

The SWB-output monthly recharge grids were converted to daily mean recharge grids (in model units of feet per day) and used as precalibration numerical-model inputs. These inputs were then scaled with multipliers during the numericalmodel calibration. The initial steady-state recharge-rate multiplier (1.0) was allowed to vary within 2.5 percent (between 0.975 and 1.025); the initial transient recharge-rate multipliers (1.0 for each month in the period 1980-2015) were allowed to vary between 0.5 and 1.2 (Smith and others, 2021; table 8). A narrower range was required for the steady-state rechargerate multiplier to keep the numerical-model recharge closely aligned with the conceptual-model recharge.

\section{Lateral Groundwater Flows}

The edges of the active modeled area, including the bottoms of active cells, were assumed to have no lateral groundwater flows and were simulated as no-flow boundaries unless specified otherwise. Lateral groundwater flows between the Salt Fork Red River aquifer and the adjoining alluvium and terrace deposits in Texas and between the Salt Fork Red River aquifer and the Blaine aquifer were simulated by using the General-Head Boundary (GHB) package (Harbaugh and others, 2000). The flow to or from a GHB cell is the product of the GHB conductance and the difference between the watertable altitude and the GHB altitude. The GHB altitudes of model cells along the western model boundary (Texas border) were estimated based on the 2016 potentiometric surface of the aquifer. The GHB altitudes of model cells along and near the southern model boundary (Red River) were adjusted from a 10-meter DEM (USGS, 2015). When land-surface altitudes of real-world features are represented by a DEM cell, the lowest altitudes (often stream channels) and highest altitudes (hilltops) are lost and replaced by the mean land-surface altitude in the cell. The difference between the real-word altitude and the cell-averaged altitude depends on the altitude relief and the size of the cell. In this case, the GHB altitudes of model cells along and near the southern model boundary were lowered by $5 \mathrm{ft}$ to match the estimated normal altitude of the water surface in the Red River. Lateral groundwater flows across the western numerical-model boundary were likely net aquifer inflows, and lateral groundwater flows across the southern numericalmodel boundary were likely net aquifer outflows. For simplicity, GHBs simulating lateral groundwater flows to the Blaine aquifer were only placed in model cells with side faces contacting the Blaine aquifer rather than in all cells contacting the Blaine aquifer. The GHB altitudes of those model cells (ghb0; fig. 21) were assigned the altitude of the Salt Fork Red River aquifer base as determined in the hydrogeologic framework (fig. 13). The initial GHB conductance was roughly equivalent to the product of the estimated mean horizontal hydraulic conductivity of the aquifer ( $40 \mathrm{ft} / \mathrm{d}$ ) and the numerical-model cell size $(200 \mathrm{ft})$. GHB conductance values were adjusted by zones during the numerical-model calibration and were allowed to vary in the range of $500-8,000$ feet squared per day $\left(\mathrm{ft}^{2} / \mathrm{d}\right)$ for the contacts with adjoining alluvium and terrace deposits in Texas (ghb1-ghb3; fig. 21) and 500-4,000 ft2/d for the contact with the Blaine aquifer (ghb0; fig. 21).

\section{Streams}

Named streams, perennial streams, and selected other streams (Horizon Systems Corporation, 2015) were simulated by using the Streamflow-Routing package, version 2 (SFR2) (Niswonger and Prudic, 2005). Only base flow was simulated in SFR2 streams. Inflows for SFR2 stream cells included base flows routed from upstream segments, specified inflows (base flows) from tributary streams, and streambed seepage from the aquifer; outflows for SFR2 stream cells included base flows routed downstream and streambed seepage to the aquifer. The SFR2 package manages streambed seepage between the aquifer and the stream according to Darcy's Law (Darcy, 1856); the flow exchanged between the aquifer and the stream is the product of the streambed conductance and the difference between the water-table altitude and the stream stage, where the streambed conductance is the product of the hydraulic conductivity of the streambed sediments and the area of the stream channel divided by the streambed thickness. In the SFR2 package, simulated base flows are calculated for the part of the stream in each model cell, known as a reach, until the end of a segment, or group of cells (reaches) with uniform hydraulic properties, is reached during each time step. Computation of flows repeats in a downstream direction until flows are routed out of the active modeled area.

All SFR2 stream segments were initially assigned a streambed thickness of $4.0 \mathrm{ft}$, a streambed conductivity of $7.0 \mathrm{ft} / \mathrm{d}$, and a roughness coefficient of 0.035 (based on Ryter and Correll [2016]; Ellis and others [2017]; and Smith and others [2017a, b]), but these properties were adjusted during calibration within ranges of $1.0-8.0 \mathrm{ft}, 5.0-9.0 \mathrm{ft} / \mathrm{d}$, and $0.020-0.040$, respectively. The channel widths of stream segments were estimated from aerial photographs (Microsoft Corporation, 2018) and ranged from 5 to $200 \mathrm{ft}$, gradually increasing downstream. The streambed altitude of each stream segment was derived from 10-meter DEMs (USGS, 2015) and lowered by $7 \mathrm{ft}$ to account for lost spatial resolution of the stream channel (altitude averaging) caused by the large DEM cell size. Monthly base-flow inflows at the boundary of the active modeled area were estimated for the Salt Fork Red River (SFRR), Turkey Creek (TURK), and Bitter Creek (BITT) (fig. 21) because long-term streamgage data were unavailable at these locations. The specified monthly baseflow inflows for the Salt Fork Red River were assigned as 1.5 times the corresponding monthly base flows estimated at 
Table 8. Calibration parameters for the numerical groundwater-flow model of the Salt Fork Red River aquifer, 1980-2015.

[--, not applicable; GHB, general-head boundary; $\mathrm{ft}^{2} / \mathrm{d}$, square foot per day; $\mathrm{ft}$, foot; $\mathrm{ft} / \mathrm{d}$, foot per day; $\mathrm{ft}^{-1}$, per foot. A more detailed and longer version of this table is available in the associated data release (Smith and others, 2021)]

\begin{tabular}{|c|c|c|c|c|}
\hline Parameter group & $\begin{array}{l}\text { Number of } \\
\text { parameters }\end{array}$ & $\begin{array}{l}\text { Parameter names } \\
\text { or map identifier }\end{array}$ & Parameter descriptions and units & $\begin{array}{l}\text { Reference } \\
\text { figure }\end{array}$ \\
\hline drn & 7 & $\begin{array}{l}\operatorname{drn} 11-\operatorname{drn} 12 \\
\text { drn21-drn } 22 \\
\text { drn30-drn32 }\end{array}$ & Drain conductance zones $(\mathrm{ft} 2 / \mathrm{d})$ & Figure 21 \\
\hline evt & 14 & $\begin{array}{l}\text { evtavg, evtjan- } \\
\text { evtdec, evtextd }\end{array}$ & $\begin{array}{l}\text { Steady-state saturated-zone evapotranspiration-rate mul- } \\
\text { tiplier (dimensionless), transient (monthly) saturated- } \\
\text { zone evapotranspiration-rate multiplier (dimensionless), } \\
\text { saturated-zone evapotranspiration extinction (root-zone) } \\
\text { depth (ft) }\end{array}$ & -- \\
\hline ghb & 4 & ghb0-ghb3 & GHB conductance zones $\left(\mathrm{ft}^{2} / \mathrm{d}\right)$ & Figure 21 \\
\hline hyd & 194 & $\begin{array}{l}\text { hkpp001-hkpp193, } \\
\text { vani1 }\end{array}$ & $\begin{array}{l}\text { Horizontal hydraulic conductivity pilot points }(\mathrm{ft} / \mathrm{d}) \text { and } \\
\text { vertical anisotropy (horizontal to vertical hydraulic } \\
\text { conductivity ratio; dimensionless) }\end{array}$ & Figure 21 \\
\hline sfr & 3 & sbcond, sbthic, rgh & $\begin{array}{l}\text { Streambed conductivities (ft/d), streambed thicknesses } \\
\quad(\mathrm{ft}) \text {, and channel roughness coefficient (dimensionless) }\end{array}$ & -- \\
\hline sto & 2 & sy1, ss1 & Specific yield (dimensionless) and specific storage $\left(\mathrm{ft}^{-1}\right)$ & -- \\
\hline Total & 657 & & & \\
\hline
\end{tabular}

the Wellington gage on the Salt Fork Red River. This factor was intended to account for an unknown amount of baseflow gain between the Wellington gage and the Texas border and was based on comparisons of estimated base flows at the Wellington gage and the OWRB Salt Fork Red River near Hollis, Okla., streamgage (Hollis gage; Alex Schoppa, OWRB, written commun., 2018) (fig. 1, table 1) for the shared period of record (2015-17) as well as a few synoptic streamflow (seepage-run) measurements. The specified monthly base-flow inflows for Bitter Creek were assigned as the monthly base flows estimated at the Martha gage on Bitter Creek. For periods when streamgage data were not available at this streamgage, mean monthly base-flow values averaged over the available period of record (1998-2005) were used as specified inflows. The available period of record (1960-63) at the Olustee gage was too short and drought-biased to be used for monthly base-flow inflows for Turkey Creek. Instead, the specified monthly base-flow inflows for Turkey Creek were assigned as the mean monthly base-flow values for the study period 1980-2015 at the Quanah gage on nearby Groesbeck Creek (fig. 2), which was comparable to Turkey Creek in terms of shape, orientation, geology, land cover, and drainage area. All other streams were assumed to have no inflows at the boundary of the active modeled area of the numerical model. Thirty-two permitted surface-water diversions, which were all on Bitter Creek or Turkey Creek (OWRB, 2019d; fig. 6), were consolidated for simplicity and simulated at three locations (pTURK1, pBITT1, and pBITT2; fig. 21). These simulated diversions removed base flow from the stream (if enough base flow was available) according to the permit holder's annual permitted use (OWRB, 2019d). The annual permitted use was divided into model stress periods by using the mean monthly water demand distribution for irrigation (fig. 22; OWRB, 2012a) for Oklahoma Comprehensive Water Plan water management planning basins 38 and 39 (fig. 2).

\section{Springs and Seeps}

Some groundwater was expected to leave the Salt Fork Red River aquifer through distributed spring and seep discharge areas where terrace deposits extend across major groundwater divides. Spring and seep discharge areas surrounding the Dodson terrace and the Mangum terrace (drn11, drn12, drn21, drn22, drn30, drn31, and drn32; fig. 21) were simulated by using the Drain package (Harbaugh and others, 2000). The flow from the aquifer at a drain cell is the product of the drain conductance and the difference between the watertable altitude and the drain altitude. Flow between the aquifer and drain cells functions the same way as in the GHB package, except that there is no drain flow into the aquifer when the water-table altitude is less than the drain altitude. The initial drain conductance varied by location but was roughly equivalent to the horizontal hydraulic conductivity of the aquifer multiplied by the length of one numerical-model cell (about $3,000-8,000 \mathrm{ft}^{2} / \mathrm{d}$ ). During calibration, drain conductance values were grouped, and each group was allowed to vary 


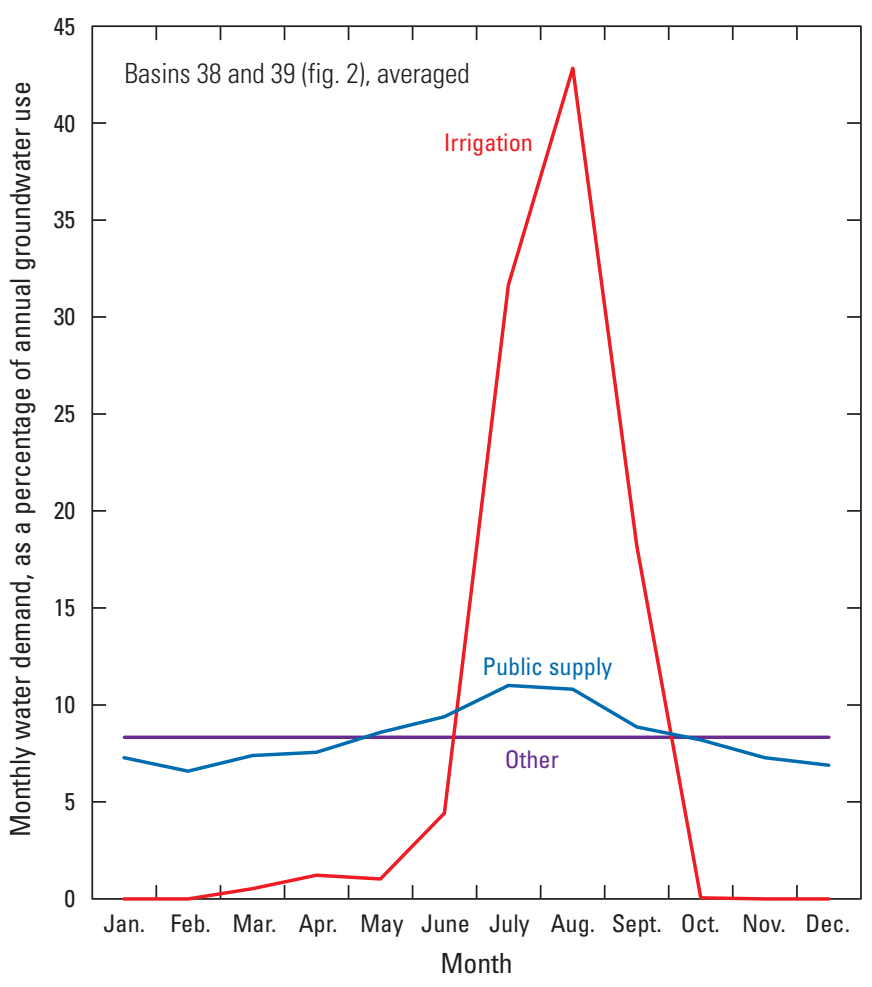

Modified from Oklahoma Water Resources Board (2012a)

Figure 22. Monthly water demand by groundwater-use type for Oklahoma Comprehensive Water Plan water management planning basins 38 and 39, 2010.

between 500 and $8,000 \mathrm{ft} 2 / \mathrm{d}$. The drain altitude was assigned as the DEM altitude minus 5-7 ft to account for lost spatial resolution caused by the DEM cell size (10 meters). Lake Hall (fig. 21) was simulated with 42 cells by using the Time-Variant Specified-Head (CHD) package (Harbaugh and others, 2000), primarily because those cells were a source of model instability; those cells, however, were downgradient from nearly all water-table-altitude observations and far from base-flow observations used in model calibration. Flow to or from specified-head cells was a negligible part of the numericalmodel water budget.

\section{Saturated-Zone Evapotranspiration}

Saturated-zone evapotranspiration was simulated by using the Evapotranspiration package (Harbaugh and others, 2000) and was expected to occur in the active alluvium near streams and in wooded spring and seep areas along the margins of the Dodson terrace and Mangum terrace. Maximum rates of saturated-zone evapotranspiration were assumed to be proportional to the difference between potential and actual evapotranspiration as computed by SWB; this assumption prevented the summed components of evapotranspiration from exceeding the potential evapotranspiration. Arrays representing the potential minus actual evapotranspiration for each stress period were initially scaled by a factor of 0.65 . During calibration, the scaling factors were allowed to vary independently in the range of $0.50-1.25$. The evapotranspiration extinction (root-zone) depth, or the depth below land surface at which the saturated zone becomes inaccessible to plants, was initially assigned a scaling factor of 1.0 and averaged about $1.2 \mathrm{ft}$ in the active modeled area, which was consistent with the mean plant root-zone depth specified for shrubland and crops in SWB. During calibration, the evapotranspiration extinction depth scaling factor was allowed to vary in the range of $0.80-1.25$.

\section{Well Withdrawals}

Well withdrawals for the study period 1980-2015 were simulated by using the Well package (Harbaugh and others, 2000). Annual reported groundwater use for each permit was evenly distributed among all the well locations recorded for that permit (OWRB, 2019d). For permits that had no recorded wells, a single well was placed in the center of the land parcel recorded for the permit. Annual reported groundwater use was temporally split into model stress periods by using the mean monthly water demand distribution (fig. 22; OWRB, 2012a) for Oklahoma Comprehensive Water Plan water management planning basins 38 and 39 (fig. 2). The monthly water demand for irrigation was greatest in the summer months; JulySeptember accounted for about 93 percent of irrigation water use. The monthly water demand for public supply also was greatest in the summer months; however, July-September only accounted for about 31 percent of public-supply water use.

\section{Storage and Hydraulic Properties}

The Upstream Weighting package (Niswonger and others, 2011) was used to represent storage and hydraulic properties of the Salt Fork Red River aquifer. The vertical anisotropy (ratio of horizontal to vertical hydraulic conductivity), specific yield, and specific storage of the Salt Fork Red River aquifer were initially assumed to be $10,0.10$, and $1 \times 10^{-5}$, respectively. These initial storage and hydraulic property values were similar to those of published numerical models for aquifers in western Oklahoma, especially the numerical model for the North Fork Red River aquifer (Smith and others, 2017b). On the basis of available lithologic log data, however, the deposits of the Salt Fork Red River were found to be slightly finer on average than those of the North Fork Red River. The initial values selected for the Salt Fork Red River aquifer, therefore, reflect this finding. The storage and hydraulic property values were adjusted during model calibration but were held spatially uniform and temporally constant through all stress periods in all simulations. Horizontal hydraulic conductivity was represented by using 193 pilot points (fig. 21; Doherty, 2010) placed at 9,000-ft intervals (one at every 45 columns and rows) within a 10,000-ft buffer of the aquifer boundary. The pilot points were assigned an initial horizontal hydraulic conductivity value of $40.0 \mathrm{ft} / \mathrm{d}$ and interpolated before each 
model run to create the horizontal hydraulic conductivity array read by the numerical model (Doherty, 2010). During calibration, pilot-point horizontal hydraulic conductivity values were allowed to vary independently between 10 and $80 \mathrm{ft} / \mathrm{d}$ (Smith and others, 2021; table 8).

\section{Solver Settings and Budget Percentage Discrepancies}

Most of the settings for the Newton solver were unchanged from suggested input values (Winston, 2018) and were converted to model units of feet and days. The head tolerance was increased to $2.0 \times 10^{-3} \mathrm{ft}$, and the flux tolerance was increased to $5.0 \times 10^{4}$ cubic feet per day. These settings improved model stability while keeping solution budget percentage discrepancies under 1.0 percent for all 433 stress periods; the largest budget percentage discrepancy was 0.6 percent in stress period 367 (Smith and others, 2021).

\section{Calibration}

Model calibration is the process of systematically changing selected model input values (parameters) within limits to improve the fit between model-simulated data and observed data (calibration targets). The preferred calibration results (1) minimize the differences (residuals) between simulated and observed data and (2) conform to the predetermined conceptual model. The calibration process for the numerical model included manual adjustment and automated adjustment of parameters. The manual calibration was primarily focused on aligning the numerical-model water budget, especially the recharge and streambed-seepage components, to the conceptual-model water budget. The automated calibration approach focused solely on minimizing residuals and used the PEST++ iterative ensemble smoother (White, 2018) to reduce run times associated with the calibration of highly parameterized models.

\section{Calibration Targets}

The suite of calibrated parameter values was evaluated based on the minimization of an objective function that was calculated as the sum of squared weighted residuals for calibration targets in three observation groups: water-tablealtitude observations, base-flow observations at the Mangum gage, and base-flow observations at the Elmer gage (table 9). Observation weights were required to prevent calibration targets of any one observation group from dominating the objective function and, therefore, becoming the sole focus of parameter adjustments during automated calibration (Hill and Tiedeman, 2007; Doherty, 2010). The observation weights $\left(1.0,7.0 \times 10^{-6}\right.$, and $2.5 \times 10^{-6}$ for water-table-altitude observations, base-flow observations at the Mangum gage, and base-flow observations at the Elmer gage, respectively) were uniform for all observations within each observation group. The observation weights were chosen so that, at the beginning of automated calibration, the observation groups accounted for 39.3 percent, 29.4 percent, and 31.3 percent of the objective function, respectively (table 9 ). This weighting scheme reflects an assumption that base-flow observations (totaling 60.7 percent of the objective function) are more important than watertable-altitude observations for the purpose of determining the parameter values that are most influential in estimating water availability (the primary subject of this report); base flows are generally more sensitive to changes in specific yield, which is a primary factor determining the volume of water in the aquifer, whereas water-table altitudes are generally more sensitive to changes in horizontal hydraulic conductivity, which is a primary factor determining the rates of groundwater flow in the aquifer. Also, because the Mangum and Elmer gage locations monitor base flows originating from all areas upstream, these base-flow observations are more likely to summarize regional (rather than localized) conditions in the aquifer than a relatively few well observations.

\section{Water-Table-Altitude Observations}

The Head Observation (HOB) package (Hill and others, 2000) was used to compare simulated water-table altitudes to observed water-table altitudes in the Salt Fork Red River aquifer for the numerical-model period 1980-2015. Observed water-table altitudes were screened for location errors and filtered such that only one observation per cell per stress period was included. Only 302 water-table-altitude observations (OWRB, 2019a; USGS, 2019) from 63 wells were included in the HOB package; 198 of these measurements were made during 1986-88 to support reports by Runkle and others (1997) and Runkle and McLean (1995), and 76 measurements were made during 2014-16 to support this report (fig. 23A). Water-table-altitude observations from March 2016, which were not taken during the model period (1980-2015), were assigned to December 31, 2015, in the HOB package, so they could be used as model calibration targets. Water-table-altitude observations were averaged by well to derive calibration targets for the steady-state simulation because no observations were available at the beginning of the numerical-model period (1980; fig. 23A).

\section{Base-Flow Observations}

Base-flow observations were available for the full study period (432 months) at two streamgages (the Mangum and Elmer gages) on Salt Fork Red River (fig. 23B) within the active modeled area. The monthly mean base flows for the two streamgages (table 4), accounting for 864 observations (table 9), were used as calibration targets for the transient simulation. The mean annual base flows for the two streamgages (table 4), accounting for two observations (table 9), were used as calibration targets for the steady-state simulation. Base-flow observations from other selected streamgages were not used as calibration targets because they (1) were previously used to define inflows for SFR2 or (2) had periods of record that were too short to be representative of streamflow conditions during the study period. 
Table 9. Components of the objective function for the automated calibration of the numerical groundwater-flow model of the Salt Fork Red River aquifer, $1980-2015$.

[Min, minimum; Max, maximum; RMSE, root-mean-square error; ft, feet; $\mathrm{ft} / \mathrm{s}$, cubic feet per second; OWRB, Oklahoma Water Resources Board; Objective function is calculated as the sum of squared weighted residuals]

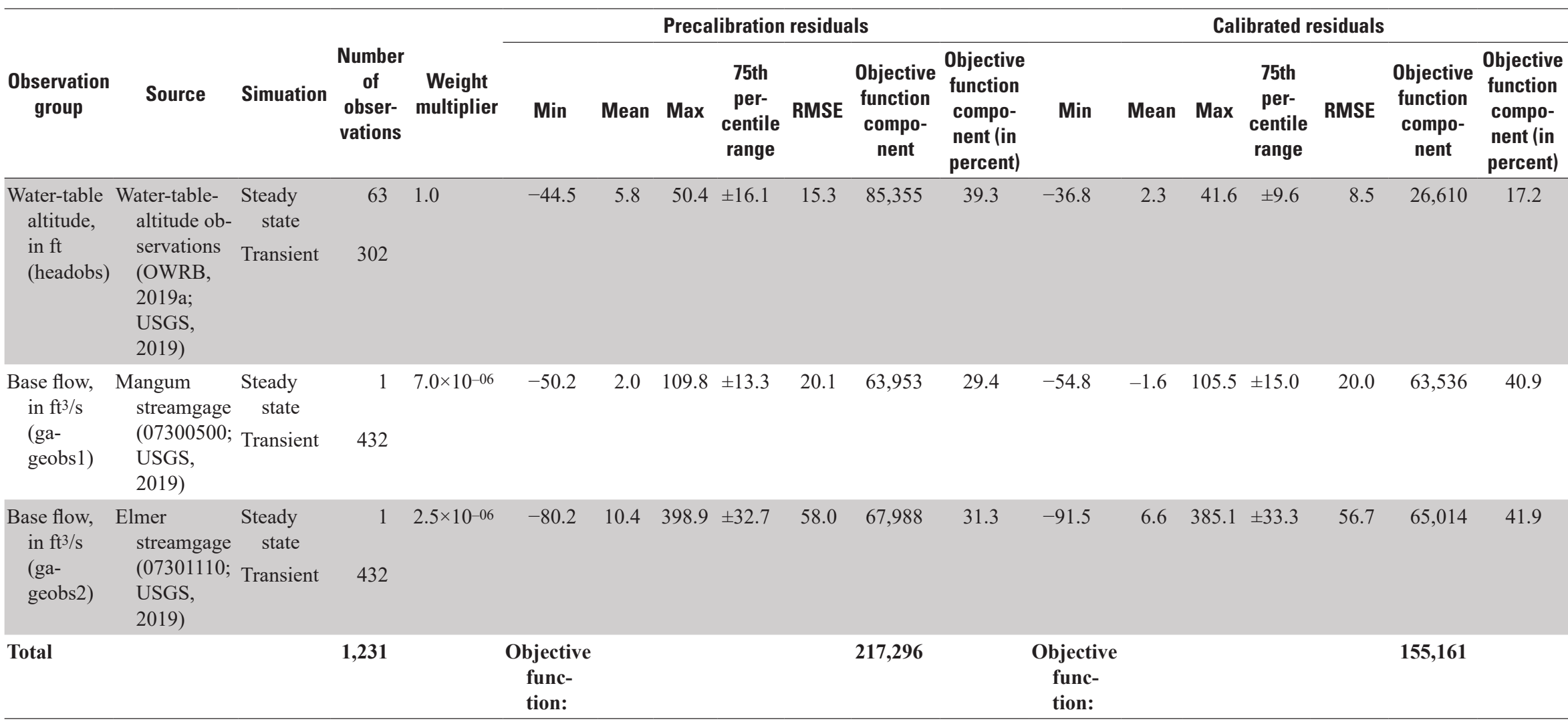



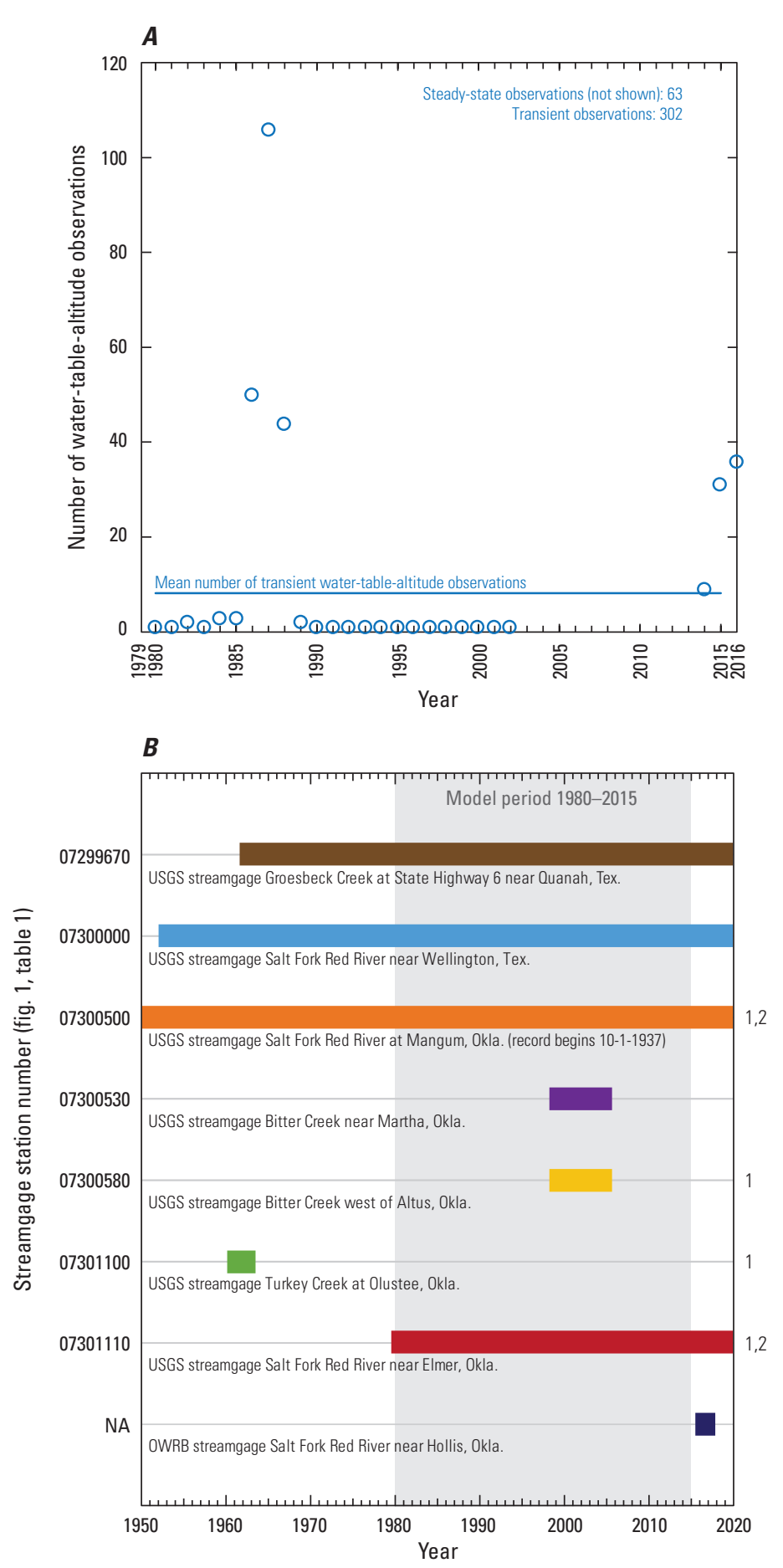

1, Used for manual numerical groundwater-flow model calibration

2, Used for automated numerical groundwater-flow model calibration

NA, Not applicable

USGS, U.S. Geological Survey

OWRB, Oklahoma Water Resources Board

Figure 23. Temporal distribution of U.S. Geological Survey (USGS) and Oklahoma Water Resources Board (OWRB)

$A$, water-table-altitude observations; and $B$, streamflow observations used for the numerical groundwater-flow model of the Salt Fork Red River aquifer, southwestern Oklahoma.

\section{Calibration Results}

Calibration results were evaluated based on the reduction of the objective function and the general fit of the calibrated numerical-model water budget to the predetermined conceptual-model water budget. Automated calibration reduced the objective function total by about 29 percent from precalibration inputs (table 9). Most of that reduction resulted from reducing water-table-altitude residuals. Base-flow residuals were mostly reduced during a round of manual calibration prior to calculation of the precalibration objective function.

\section{Observation-Sensitivity Analysis}

As part of the calibration process, an observationsensitivity analysis was performed with the iterative parameter estimation software package PEST (Doherty, 2010) to identify which parameters were most effective (and most ineffective) at reducing the objective function. PEST measures the changes in calibration-target residuals resulting from 1-percent changes in each parameter and records those changes in a matrix with dimensions equal to the number of observations times the number of parameters (Doherty, 2010). Parameters with the greatest effects on calibration-target residuals have the greatest observation sensitivities (Smith and others, 2021).

Parameters that were closely linked, either spatially or temporally, to observations typically had the greatest observation sensitivities in the Salt Fork Red River aquifer numerical model. Parameters with the greatest observation sensitivities were the GHB conductance governing lateral-groundwater-flow exchange with the Blaine aquifer (ghb0), the steady-state recharge-rate multiplier (rch001), horizontal hydraulic conductivity pilot points 56 and 57 (hkpp056 and hkpp057), and the specific yield (sy1) (Smith and others, 2021; table 8). The ghb0 parameter influenced how much groundwater was lost in the narrow part of the aquifer just upstream from the Mangum gage (fig. 21) and, therefore, strongly influenced how much base flow was simulated in the Salt Fork Red River at that streamgage. The rch001 parameter determined how much recharge was applied in the steady-state simulation, which included many (62 of 365) of the water-table-altitude observations (Smith and others, 2021). The horizontal hydraulic conductivity pilot points 56 and 57 (hkpp056 and hkpp057) were in a part of the aquifer with a large spatial concentration of wells with associated water-table-altitude observations. The syl parameter controlled the volume of water released (from storage) as streambed seepage to streams across the entire aquifer, which in turn partially controlled how much base flow was simulated in the Salt Fork Red River at the Mangum and Elmer gages. Parameters with zero observation sensitivity (no effect on observations) were fixed at their initial precalibration values during automated calibration (Smith and others, 2021). All but one of these 
fixed parameters were recharge-rate multipliers in months with little to no recharge or horizontal hydraulic conductivity pilot points located outside of the active modeled area; drain conductance for zone 22 (fig. 21) was the only other parameter that remained fixed during automated calibration (Smith and others, 2021).

To graphically summarize the observation sensitivity analysis, observation-grouped sensitivities were calculated as the weighted sum of the Jacobian matrix output for each parameter group (fig. 24). Because recharge parameters influence every cell in the model, the recharge parameter group had the greatest observation-group sensitivities. The drain conductance parameter group had the lowest observation-group sensitivities.

\section{Calibrated Parameter Values}

The calibrated parameter values (Smith and others, 2021) selected for the numerical model were the combined result of manual and automated calibration approaches. Some of the calibrated parameter values were set to the minimum or maximum bounds specified in the PEST control file. For the recharge parameter group, 154 of 433 calibrated recharge-rate multiplier values were assigned to either the minimum or maximum bounds; 22 of those values were at the minimum bound (0.50), and 132 were at the maximum bound (1.20) (Smith and others, 2021). For the hydraulic conductivity parameter group, 68 of 194 calibrated parameter values were assigned to either the minimum or maximum bounds; 22 of those values were at the minimum bound $(10 \mathrm{ft} / \mathrm{d})$, and 46 were at the maximum bound ( $80 \mathrm{ft} / \mathrm{d}$ ) (Smith and others, 2021; fig. 25). Three of the calibrated parameter values (evtfeb, evtjun, and evtsep) in the evapotranspiration group were at the minimum bound $(0.50)$ for that group, and the calibrated parameter value for drn 12 in the drain conductance group was at the maximum bound for that group (Smith and others, 2021). Calibrated parameter values at bounds indicate that the objective function could likely be further reduced by expanding those bounds; doing so, however, would divert the numerical model further from the conceptual model. The streambed conductivity calibrated parameter value (sbcond) was at the maximum bound of $9.0 \mathrm{ft} / \mathrm{d}$; this bound was necessary to prevent model instability that tended to occur in conjunction with larger values of streambed conductivity.

The calibrated parameter values for the numerical model of the Salt Fork Red River aquifer (Smith and others, 2021) can be compared with those for a numerical model of the adjacent, analogous Seymour aquifer in Texas (Ewing and others, 2004). Although the models were developed independently, similar methods were used to develop both, and the calibrated parameters used in each model were similar. The biggest

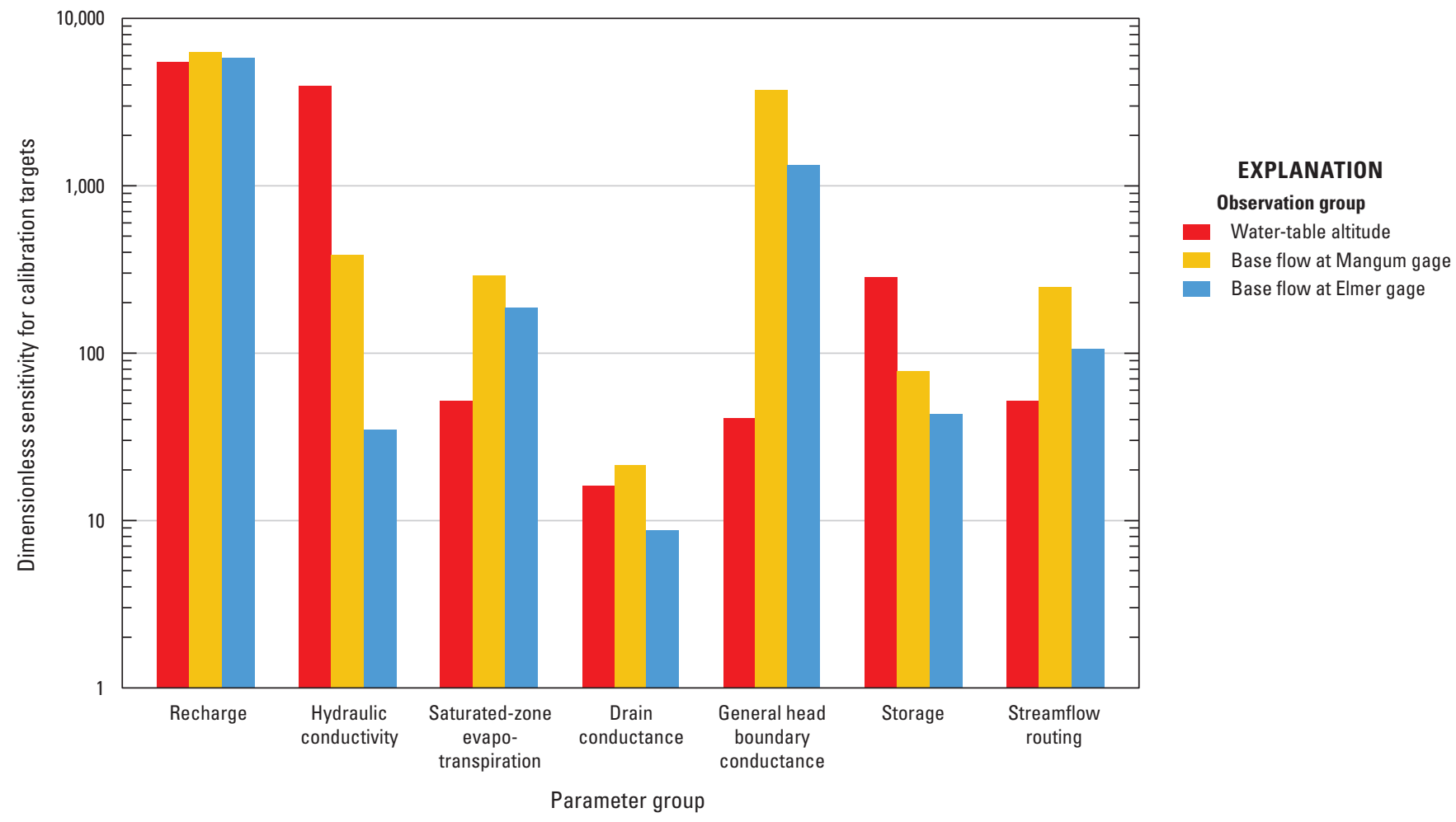

Note: Magnum gage refers to U.S. Geological Survey (USGS) streamgage 07300500 Salt Fork Red River at Mangum, Okla., and Elmer gage refers to USGS streamgage 07301110 Salt Fork Red River near Elmer, Okla. (fig. 1, table 1)

Figure 24. Observation group sensitivity by parameter group in the numerical groundwater-flow model of the Salt Fork Red River aquifer, 1980-2015. 


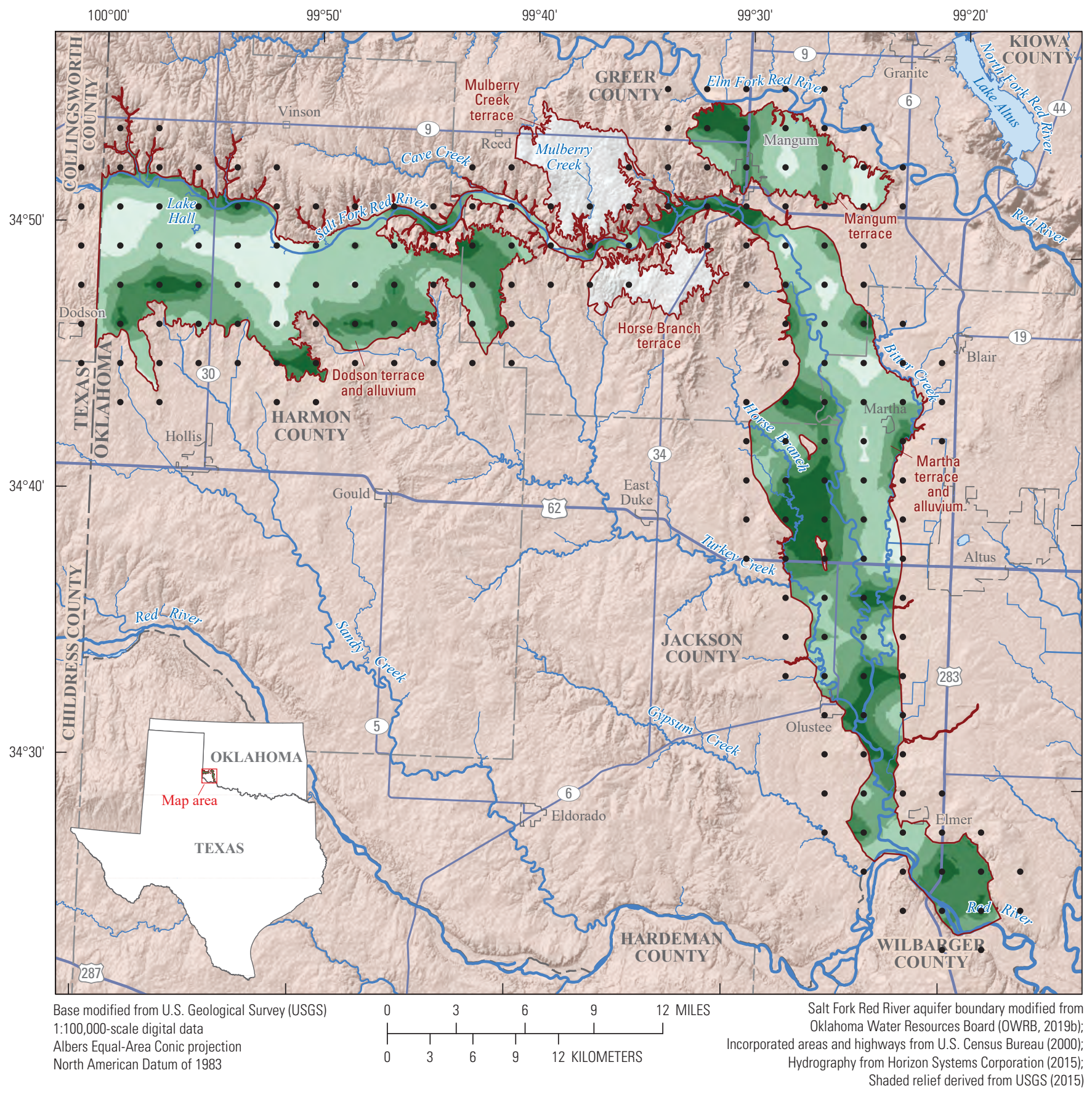

EXPLANATION

\begin{tabular}{|c|}
\hline $\begin{array}{l}\text { Calibrated horizontal hydraulic conductivity, } \\
\text { in feet per day }\end{array}$ \\
\hline 10.0 to 16.0 \\
\hline 16.1 to 32.0 \\
\hline 32.1 to 48.0 \\
\hline 48.1 to 64.0 \\
\hline 64.1 to 80.0 \\
\hline $\begin{array}{l}\text { Salt Fork Red River aquifer excluded from } \\
\text { the active modeled area }\end{array}$ \\
\hline Salt Fork Red River aquifer boundary \\
\hline
\end{tabular}

Figure 25. Calibrated horizontal hydraulic conductivity for the numerical groundwater-flow model of the Salt Fork Red River aquifer, southwestern Oklahoma. 
difference in hydraulic parameters was in the vertical anisotropy, which was 18.62 in this report and 10,000 in Ewing and others (2004), but observations in both models were relatively insensitive to the vertical anisotropy parameter. In fact, vertical anisotropy has no influence in the context of a 1-layer, 2-dimensional (horizontal) groundwater-flow model like the one described in this report (Harbaugh, 2005). Streambed conductivity $(9.0 \mathrm{ft} / \mathrm{d}$ in this report and $0.25 \mathrm{ft} / \mathrm{d}$ in Ewing and others [2004]) also differed by more than an order of magnitude, possibly because the model by Ewing and others (2004) was not calibrated to base flows. Calibrated horizontal hydraulic conductivity (averaging $40 \mathrm{ft} / \mathrm{d}$ in this report and $66 \mathrm{ft} / \mathrm{d}$ in Ewing and others [2004]) and specific yield (0.12 in this report and 0.14 in Ewing and others [2004]) were similar in both models. Ewing and others (2004) simulated $2.5 \mathrm{in} / \mathrm{yr}$ of recharge for the model period 1980-99 in the Seymour aquifer (called pod 1 by Ewing and others [2004]) compared to $2.9 \mathrm{in} / \mathrm{yr}$ for the model period 1980-2015 in the Salt Fork Red River aquifer; those rates were comparable, though the use of different model periods complicates the comparison.

\section{Comparison of Simulated and Observed Calibration Targets}

Conforming to MODFLOW convention, calibrationtarget residuals in this report were calculated as observed minus simulated values; positive residuals indicate lower simulated than observed values, and negative residuals indicate higher simulated than observed values. The mean calibrated residual for water-table-altitude observations was $2.3 \mathrm{ft}$ (table 9), indicating that, on average, simulated water levels were slightly lower than observed water levels. The combined water-table-altitude root-mean-square error (RMSE) was $8.5 \mathrm{ft}$, and 75 percent of residuals were within plus or minus $( \pm) 9.6 \mathrm{ft}$ of observed measurements (table 9, fig. 26B).

Water-table-altitude residuals were generally largest (simulated less than observed) in the middle of the Dodson terrace (figs. $26 \mathrm{~A}$ and 27), where observed hydraulic gradients slope steeply towards the Salt Fork Red River, drains, and tributary streams. Simulated water levels that are less than observed water levels in the upgradient terrace could be explained by differences between the complexity (resolution) of the simulated and observed aquifers. Because of generalizations inherent in spatial discretization, simulated flow paths are likely simplified and shortened versions of actual flow paths (Mandelbrot, 1983). Simulated hydraulic gradients and recharge-to-discharge travel times, therefore, are likely to be smaller than observed, and the discrepancy between simulated and observed travel times is likely to increase with increased hydraulic gradients like those observed in the upgradient terraces. Simulated water levels in the western part of the Dodson terrace (near ghb1, fig. 21) and in the Mangum terrace were generally higher than observed water levels (figs. $26 \mathrm{~A}$ and 27). Only one well (9442 [OWRB, 2019a], figs. 1 and 26C) had multiple water-table-altitude observations per year over a period of more than 3 years (1980-2002), and this well is near the northern edge of the Mangum terrace. The simulated water levels for that well were about $7 \mathrm{ft}$ higher than the observed water levels, but the patterns and trends in the hydrographs were similar (fig. 26C).

The mean calibrated residual for base-flow observations at the Mangum gage was $-1.6 \mathrm{ft} 3 / \mathrm{s}$ (table 9), indicating that, on average, simulated base flows were slightly higher than observed base flows. The combined Mangum gage base-flow RMSE was $20.0 \mathrm{ft} 3 / \mathrm{s}$, and 75 percent of residuals were within $\pm 15.0 \mathrm{ft} 3 / \mathrm{s}$ of observed measurements. The mean calibrated residual for base-flow observations at the Elmer gage was $6.6 \mathrm{ft} 3 / \mathrm{s}$, indicating that, on average, simulated base flows were slightly lower than observed base flows. The combined Elmer gage base-flow RMSE was $56.7 \mathrm{ft} 3 / \mathrm{s}$, and 75 percent of residuals were within $\pm 33.3 \mathrm{ft} 3 / \mathrm{s}$ of observed measurements. Although simulated base flows generally matched the pattern of observed base flows, they often failed to reach the high and low extremes. For example, the simulated base flows failed to reach the highest observed base flows from 1987 and 1997-98 at the Mangum and Elmer gages (figs. 28A, B). Likewise, the simulated base flows never reached $0 \mathrm{ft}^{3} / \mathrm{s}$ to match the observed summer base flows in most years at the Mangum gage and in 2011-14 drought conditions at both streamgages. The failure to simulate observed extremes is typical of groundwater-flow models (Ellis and others, 2017; Smith and others, 2017a) and probably results from discretization, or the necessary simplification in numerical groundwater-flow models of spatially and temporally variable hydrologic processes that occur in the real world (Mandelbrot, 1983).

\section{Calibrated Numerical-Model Water Budget}

The calibrated numerical-model water budget (table 10, fig. 16B) shows mean annual inflows and outflows for the model period 1980-2015; a subaccounting for areas upgradient and downgradient from the Mangum gage (07300500) was computed by using the ZONEBUDGET utility (Harbaugh, 1990). Simulated recharge (38,312 acre-ft/yr) was the only inflow for the calibrated numerical model. Net streambed seepage (50.1 percent of outflows) was the largest outflow for the calibrated numerical model; springs and seeps accounted for 25.8 percent, saturated-zone evapotranspiration accounted for 8.8 percent, well withdrawals accounted for 7.6 percent, and net lateral groundwater flow accounted for 7.3 percent of outflows (table 10, fig. 16B). Most components of the numerical-model water budget compare well with the conceptual-model water budget (table 6, fig. 16B). The saturated-zone evapotranspiration and springs and seeps components, however, differed substantially between the two model budgets. These components of the conceptual model were poorly constrained by available field data. The types of field activities required to effectively model saturated-zone evapotranspiration and springs and seeps components are difficult to conduct, and the resulting data are expensive to collect and integrate at the scale of the study area. 


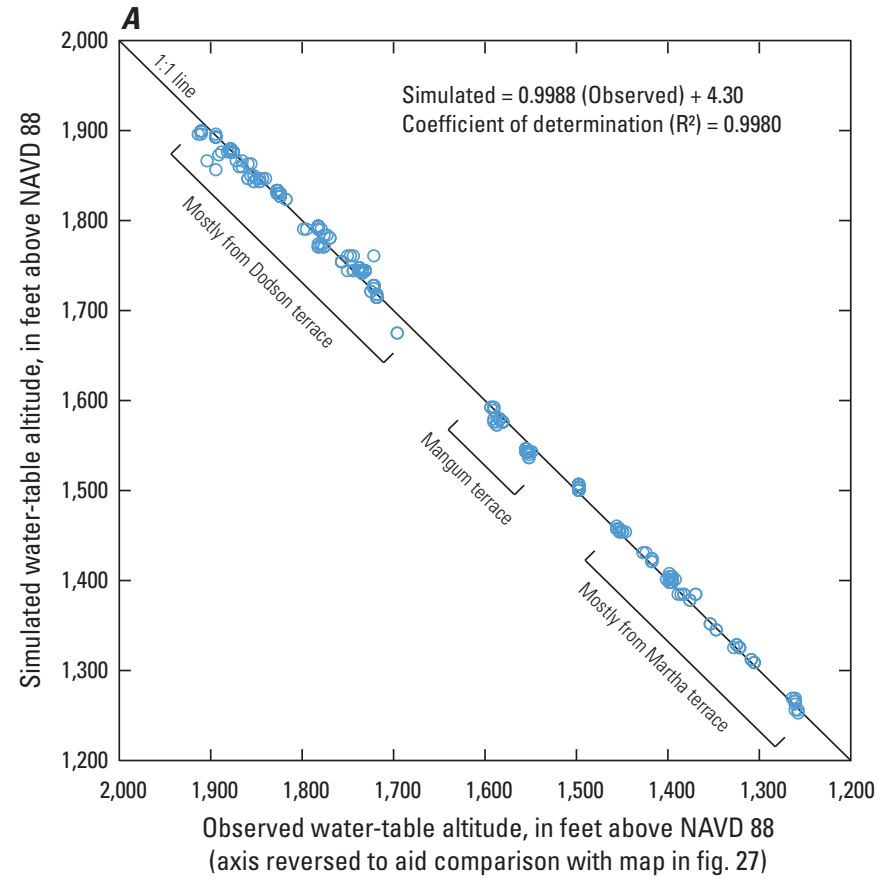

NAVD 88, North American Vertical Datum of 1988

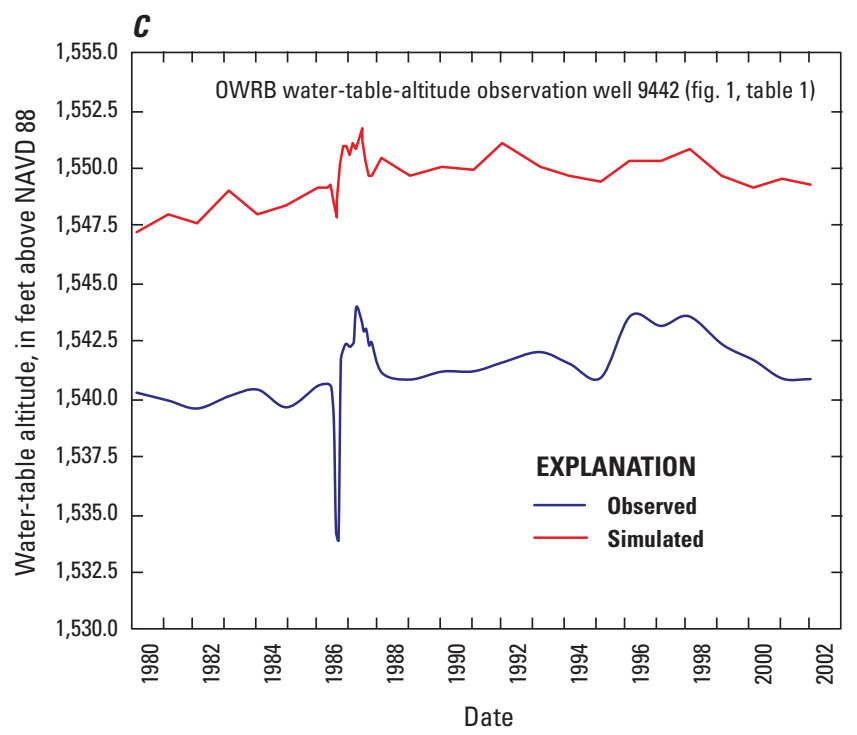

NAVD 88, North American Vertical Datum of 1988 OWRB, Oklahoma Water Resources Board

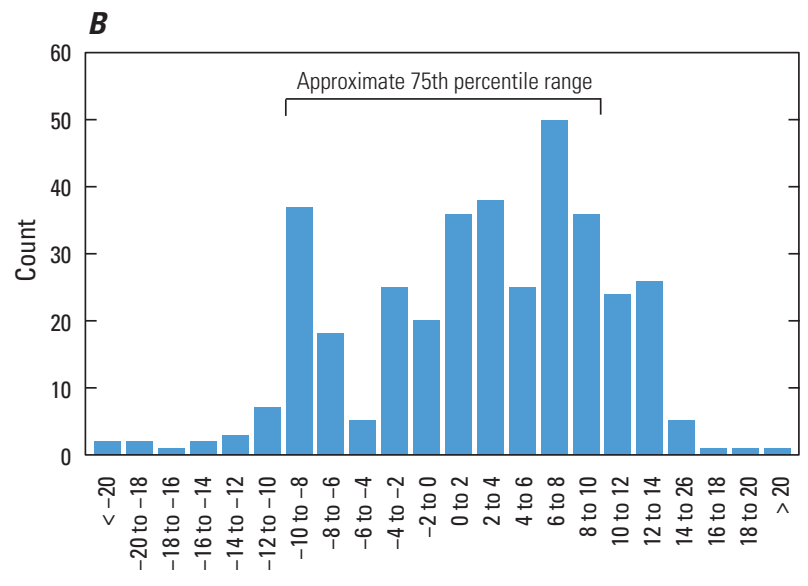

Water-table-altitude residual (observed minus simulated), in feet

$<$, Less than

$>$, Greater than

Figure 26. $A$, Relation between simulated and observed water-table altitudes; $B$, water-table-altitude residual distribution; and $C$, observed and simulated water-table altitudes for Oklahoma Water Resources Board (OWRB) well 9442 for the numerical groundwater-flow model of the Salt Fork Red River aquifer, southwestern Oklahoma, 1980-2015. 


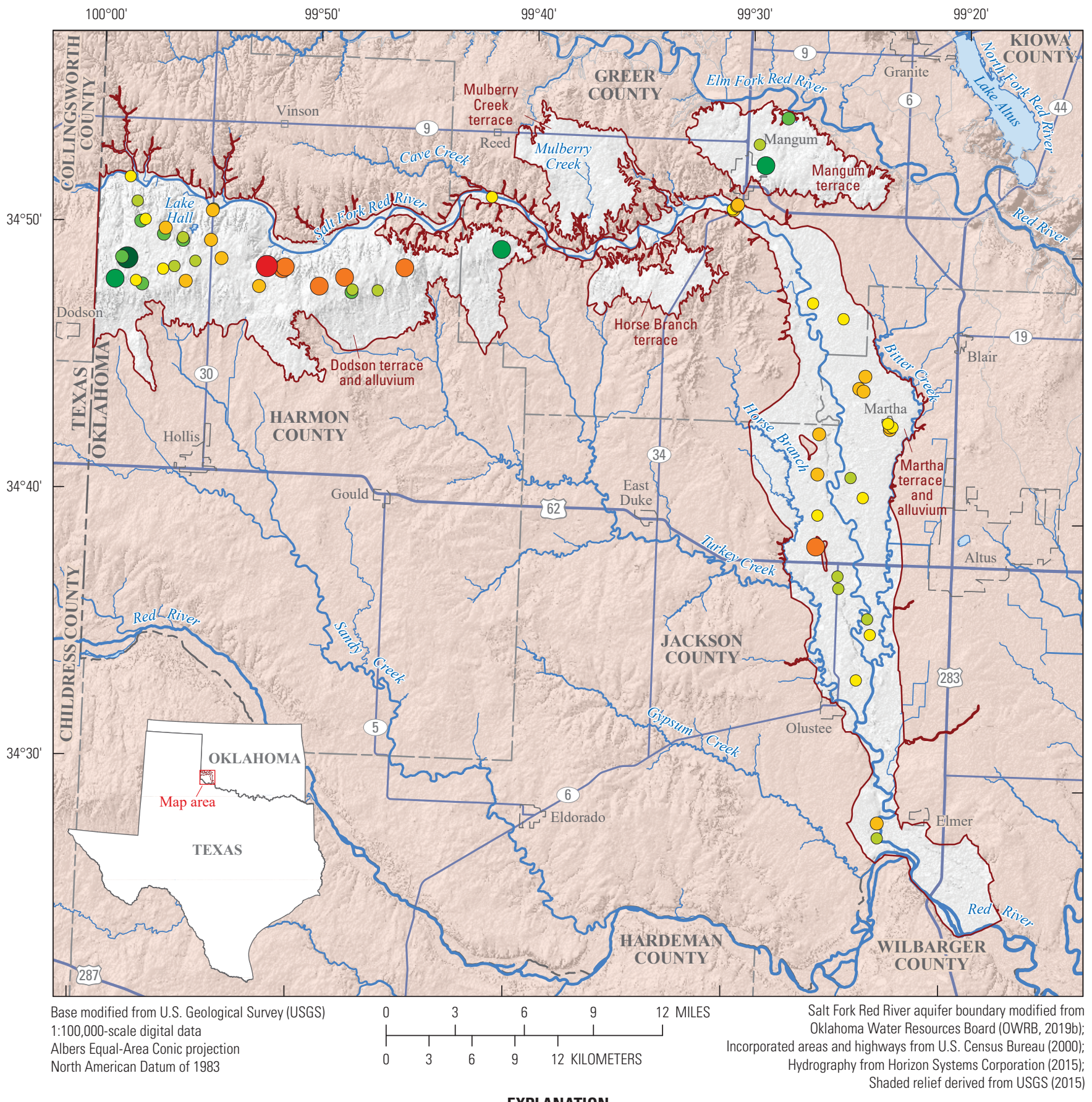

\section{EXPLANATION}

Salt Fork Red River aquifer

Mean water-table-altitude residual (observed minus

simulated) at observation wells, in feet, 1980-2015

$\begin{array}{lll}-28.5 \text { to }-20.0 & \bigcirc & 0.1 \text { to } 5.0 \\ -19.9 \text { to }-10.0 & \bigcirc & 5.1 \text { to } 10.0 \\ 10.1 \text { to } 20.0 \\ 20.1 \text { to } 26.3\end{array}$

Figure 27. Mean water-table-altitude residuals at individual wells used to calibrate the numerical groundwater-flow model of the Salt Fork Red River aquifer, southwestern Oklahoma, 1980-2015. 
A. U.S. Geological Survey streamgage 07300500 Salt Fork Red River at Mangum, Okla. (fig. 1, table 1)

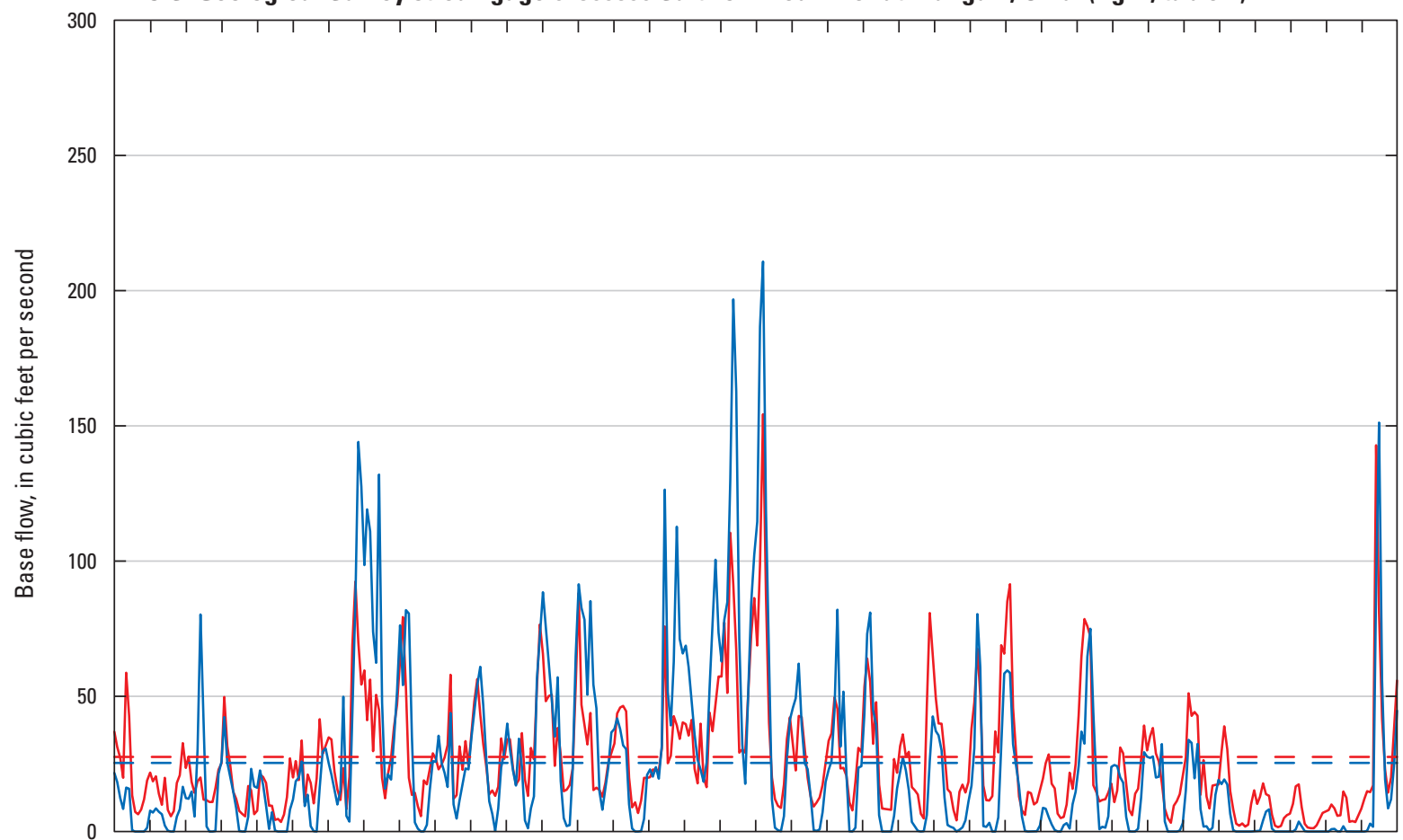

B. U.S. Geological Survey streamgage 07301110 Salt Fork Red River near Elmer, Okla. (fig. 1, table 1)

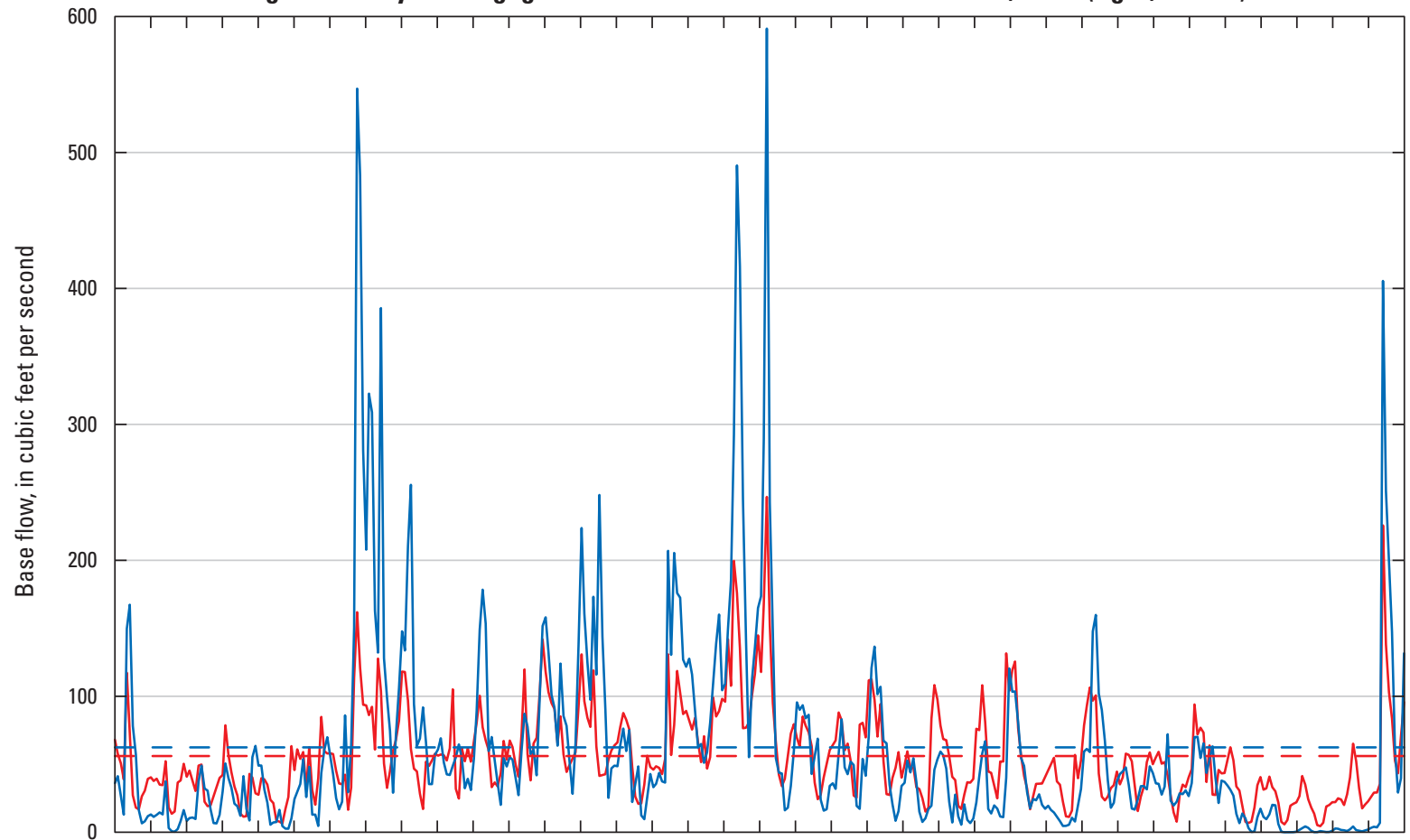

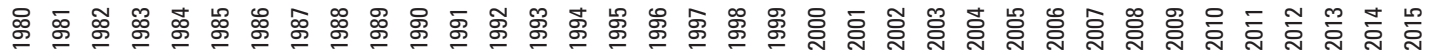

Date

EXPLANATION

\begin{tabular}{|c|c|}
\hline Base flow, observed, transient simulation & - - Base flow, observed, steady-state simulation \\
\hline
\end{tabular}

Figure 28. Observed base flow and simulated base flow at U.S. Geological Survey streamgages $A, 07300500$ Salt Fork Red River at Mangum, Okla., and B, 07301110 Salt Fork Red River near Elmer, Okla., for the numerical groundwater-flow model of the Salt Fork Red River aquifer, southwestern Oklahoma, 1980-2015. 
Table 10. Calibrated numerical-model water budget for the Salt Fork Red River aquifer, 1980-2015.

[All units in acre-feet per year. Net budget totals are calculated as the difference of outflow and inflow; negative values indicate outflow from the aquifer, and positive values indicate inflow to the aquifer]

\begin{tabular}{|c|c|c|c|c|}
\hline \multicolumn{5}{|c|}{ Transient simulation } \\
\hline Water-budget category & $\begin{array}{l}\text { Upgradient from } \\
\text { Mangum gage } \\
\text { (fig. 1, table 1) }\end{array}$ & $\begin{array}{l}\text { Downgradient from } \\
\text { Mangum gage }\end{array}$ & Total & $\begin{array}{l}\text { Percentage of } \\
\text { water budget }\end{array}$ \\
\hline \multicolumn{5}{|c|}{ Inflow } \\
\hline Recharge & 17,315 & 20,997 & 38,312 & 100.0 \\
\hline Total inflow & 17,315 & 20,997 & 38,312 & 100.0 \\
\hline Net streambed seepage ${ }^{1}$ & 4,513 & 14,576 & 19,089 & 50.1 \\
\hline Saturated-zone evapotranspiration & 2,153 & 1,222 & 3,375 & 8.8 \\
\hline Springs and seeps & 7,436 & 2,409 & 9,844 & 25.8 \\
\hline Well withdrawals & 886 & 2,031 & 2,916 & 7.6 \\
\hline \multicolumn{5}{|c|}{ Net water-budget totals } \\
\hline Net change in groundwater storage 1 & 119 & -278 & -159 & -0.4 \\
\hline
\end{tabular}

${ }^{1}$ Net streambed seepage, net lateral groundwater flow, net lakebed seepage, and net change in groundwater storage represent the net effect of aquifer inflows and outflows.

Simulated annual net groundwater storage changes reflect climatic trends during the transient-simulation model period 1980-2015 (fig. 29). The aquifer lost about 4 percent of simulated storage from 1980 to 1984 relative to the groundwater storage from the steady-state simulation (526,100 acre-ft). The aquifer quickly regained most of that lost storage by 1985 and gained an additional 8 percent of simulated storage by 1997 as a result of a historically wet and cool period (figs. $4 A, B$ ). The aquifer mostly lost storage annually from 1998 to 2014, and the cumulative net change in groundwater storage in 2014 reached about 10 percent as compared to the steady-state simulation. That lost storage was fully regained in 2015 , and the transient-simulation model period ended with a slight (less than 1 percent) storage surplus as compared to the steady-state simulation (fig. 29).

\section{Simulated Saturated Thickness and Available Water in Storage}

The simulated saturated thickness of the Salt Fork Red River aquifer was determined by subtracting the altitude of the aquifer base from the simulated water-table altitude at the end of the numerical-model period (2015). The simulated saturated thickness was more than $75 \mathrm{ft}$ in a paleochannel in the Dodson terrace near the Texas border and less than $10 \mathrm{ft}$ in the southern part of the Dodson terrace, in the western part of the Mangum terrace, and along a buried ridgeline in the western part of the Martha terrace (fig. 30). The mean aquifer thickness (sum of saturated and unsaturated) was $49.62 \mathrm{ft}$, and the mean saturated thickness was $28.55 \mathrm{ft}$ (table 11). A simulated mean transmissivity of $1,024 \mathrm{ft} 2 / \mathrm{d}$ was calculated as the mean of the calibrated horizontal hydraulic conductivity multiplied by the saturated thickness of each cell. The simulated available water in storage at the end of the numerical-model period (2015) was 526,117 acre-ft; about 42 percent of that total was available upgradient from the Mangum gage, and about 58 percent of that total was available downgradient from the Mangum gage (including the Mangum terrace) (table 11). 


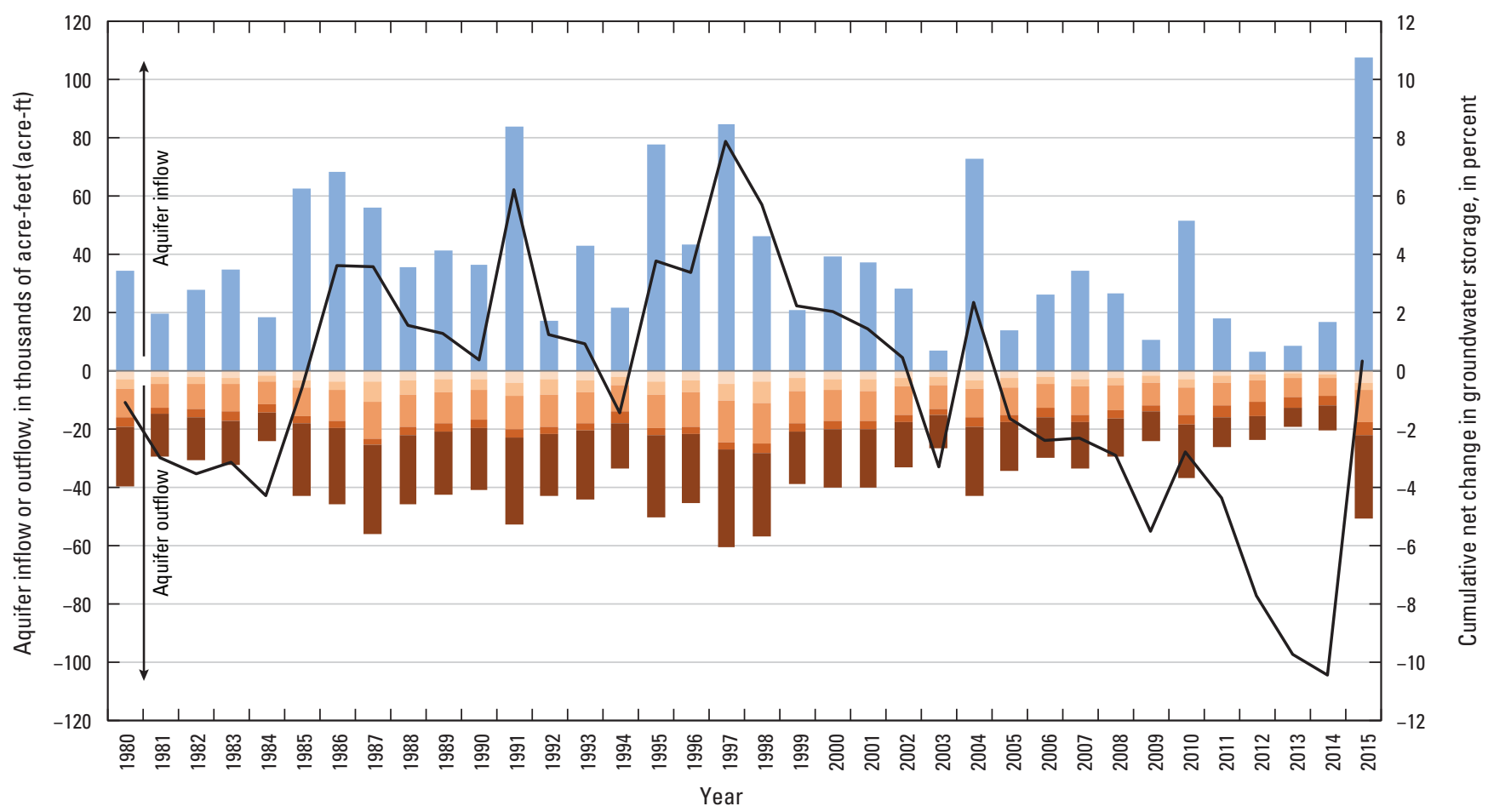

EXPLANATION

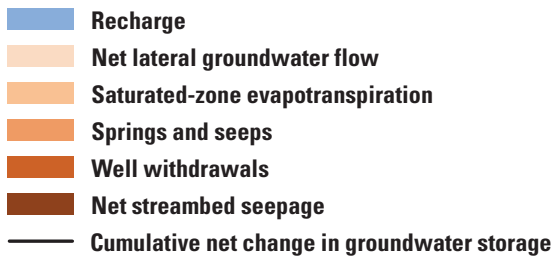

The cumulative net change in groundwater storage was referenced to the simulated groundwater storage from the steady-state simulation $(526,100$ acre-ft). Contrary to MODFLOW convention, loss of groundwater storage is shown here as an aquifer outflow (negative).

Figure 29. Annual inflows, outflows, and cumulative net change in groundwater storage for the numerical groundwater-flow model of the Salt Fork Red River aquifer, southwestern Oklahoma.

\section{Groundwater-Availability Scenarios}

Three types of groundwater-availability scenarios were run using the calibrated numerical model. These scenarios were used to (1) estimate the equal-proportionate-share (EPS) pumping rate that ensures a minimum 20-, 40-, and 50-year life of the aquifer, (2) quantify the potential effects of projected well withdrawals on groundwater storage over a 50-year period, and (3) simulate the potential effects of a hypothetical 10-year drought on base flow and groundwater storage. Groundwater storage was calculated by multiplying the calibrated specific yield $(0.1182$, Smith and others, 2021$)$ by the saturated thickness of each active model cell. The inputs and outputs for the groundwater-availability scenarios are available in Smith and others (2021).

\section{Equal-Proportionate Share}

EPS scenarios for the Salt Fork Red River aquifer were run for periods of 20, 40, and 50 years. The Time-Variant Specified-Head package was deactivated during these scenarios to prevent the spring-fed Lake Hall from acting as a source of unlimited inflow to the aquifer; thus, Lake Hall was not simulated in these scenarios. The 2015 simulated water table from the calibrated numerical model was used as the starting water table in each EPS scenario. Model inputs for recharge, saturated-zone evapotranspiration, and stream inflows to the active modeled area were configured as the means of each annual period used in the calibrated numerical model. Simulated wells from the calibrated model were discarded, and a hypothetical well was placed in each active cell (covering about 0.92 acre). Annual stress periods were used in these scenarios instead of monthly stress periods in order to simplify the analysis and improve model stability. 


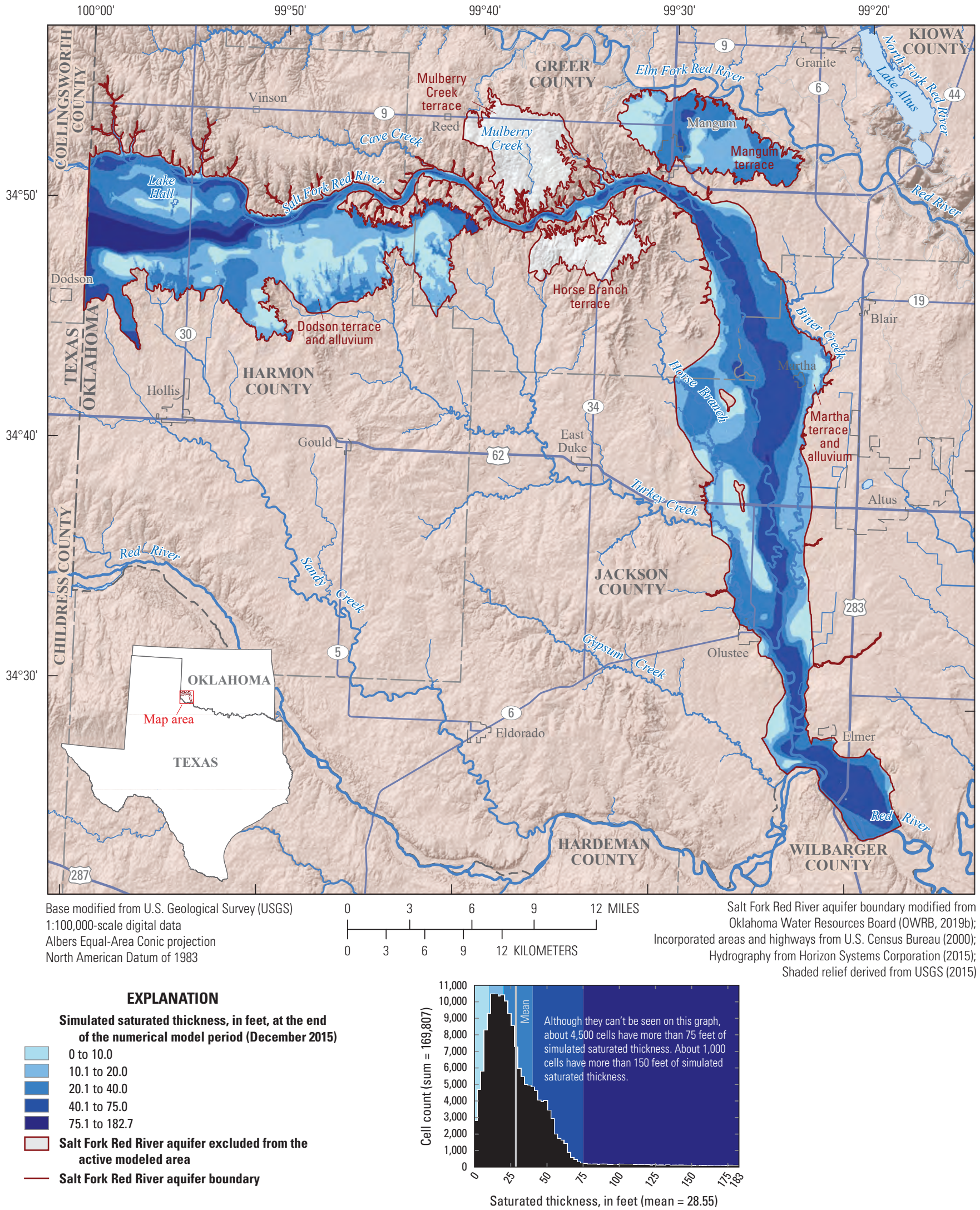

Figure 30. Simulated saturated thickness at the end of the period 1980-2015 for the calibrated numerical model of the Salt Fork Red River aquifer, southwestern Oklahoma. 
Table 11. Hydraulic properties, storage properties, and available water in storage at the end of the numerical-model period for the Salt Fork Red River aquifer, $1980-2015$.

[Kh, horizontal hydraulic conductivity]

\begin{tabular}{|c|c|c|c|c|c|c|c|c|c|c|}
\hline Aquifer part & Active cells & $\begin{array}{c}\text { Active cells } \\
\text { with satura- } \\
\text { tion }\end{array}$ & $\begin{array}{c}\text { Mean Kh, } \\
\text { in feet } \\
\text { per day }\end{array}$ & $\begin{array}{c}\text { Mean aquifer } \\
\text { thickness, in } \\
\text { feet }\end{array}$ & $\begin{array}{c}\text { Mean } \\
\text { saturated } \\
\text { thickness, in } \\
\text { feet }\end{array}$ & $\begin{array}{c}\text { Mean transmissiv- } \\
\text { ity, in feet squared } \\
\text { per day }\end{array}$ & $\begin{array}{l}\text { Mean } \\
\text { specific } \\
\text { yield }\end{array}$ & $\begin{array}{c}\text { Mean } \\
\text { specific } \\
\text { storage, in } \\
\text { feet }^{-1}\end{array}$ & $\begin{array}{l}\text { Available water in } \\
\text { storage, in cubic } \\
\text { feet }\end{array}$ & $\begin{array}{c}\text { Available } \\
\text { water in } \\
\text { storage, in } \\
\text { acre-feet }\end{array}$ \\
\hline $\begin{array}{l}\text { Upgradient from } \\
\text { Mangum gage } \\
\text { (fig. 1, table 1) }\end{array}$ & 70,464 & 70,458 & 34.27 & 59.68 & 28.64 & 903 & 0.1182 & $1.99 \mathrm{E}-05$ & $9,541,978,415$ & 219,054 \\
\hline $\begin{array}{l}\text { Downgradient from } \\
\text { Mangum gage }\end{array}$ & 99,343 & 99,343 & 40.34 & 42.49 & 28.48 & 1,111 & 0.1182 & $1.99 \mathrm{E}-05$ & $13,375,683,447$ & 307,063 \\
\hline Aquifer & 169,807 & 169,801 & 37.82 & 49.62 & 28.55 & $1,024^{*}$ & 0.1182 & $1.99 \mathrm{E}-05$ & $22,917,661,862$ & 526,117 \\
\hline
\end{tabular}

*The aquifer transmissivity, which was calculated as the mean of the calibrated horizontal hydraulic conductivity multiplied by the saturated thickness of each cell, cannot be calculated from the data in this table. 
PEST (Doherty, 2010), a software package for iterative parameter estimation, was used to determine the EPS pumping rate for the selected period (20,40, or 50 years). In each PEST iteration, the hypothetical wells were pumped at a uniform rate for the selected period. If more than 50 percent of the active cells had a saturated thickness of at least $5 \mathrm{ft}$ at the end of an iteration, successive iterations with an increased uniform pumping rate were performed until 50 percent of the cells had a saturated thickness of less than $5 \mathrm{ft}$. To account for potential climate variability, this process was repeated with recharge increased and decreased by 10 percent.

The 20-, 40-, and 50-year EPS pumping rates under normal recharge conditions were about $0.46,0.44$, and 0.44 acre-foot per acre per year, respectively (table 12). Given the 155,929-acre modeled aquifer area, these rates correspond to annual yields of about $71,700,68,600$, and 68,600 acre-ft/ yr, respectively. For the 20-year EPS scenario, decreasing and increasing recharge by 10 percent resulted in a 6-percent change in the EPS pumping rate in both cases; for the 40- and 50-year EPS scenarios, decreasing and increasing recharge by 10 percent resulted in a 7-percent change in the EPS pumping rate in both cases (table 12).

At the end of all EPS scenarios, the simulated groundwater storage had decreased by more than 40 percent, and simulated base flows at the Mangum and Elmer gages on the Salt Fork Red River had both decreased to about $15 \mathrm{ft} 3 / \mathrm{s}$ (figs. 31A-C). The Salt Fork Red River likely would be dry $\left(0 \mathrm{ft}^{3} / \mathrm{s}\right)$ at these streamgages if the unmodified mean streamflows had not been supplied at the streamflow-routing inflow locations (fig. 32). After 20 years of EPS pumping, only (1) the deep trough in the Dodson terrace, (2) areas adjacent to the Seymour aquifer in Texas (fig. 1), and (3) areas along streams with specified inflows (Salt Fork Red River, Turkey Creek, and Bitter Creek) retained more than $5 \mathrm{ft}$ of saturated thickness (fig. 32); areas along those streams remained saturated because they received streambed seepage supplied by specified inflows (SFRR, TURK, BITT; fig. 21).

EPS scenarios represent an extreme theoretical construct in which the whole aquifer is fully developed with regularly spaced wells (one per model cell) pumping at a high, uniform rate. This level of development is unlikely to occur, and these EPS scenarios bear little resemblance to the current (2021) level of development in the Salt Fork Red
River aquifer in terms of well distribution and pumping rates. Some parts of the aquifer may be more developed than others, but the current level of development in the aquifer as a whole is far smaller than the level of development simulated in the EPS scenarios; the total well withdrawals for 2015 $(6,033.8$ acre- $\mathrm{ft} / \mathrm{yr}$, table 3$)$, if divided by the modeled aquifer area (155,929 acres), are equivalent to an aquifer-averaged pumping rate of about 0.04 acre-foot per acre per year or about 10 percent of the 20 -year EPS pumping rate.

\section{Projected 50-Year Pumping}

Projected 50-year pumping scenarios were used to simulate the effects of modified well withdrawal rates on groundwater storage in the Salt Fork Red River aquifer and base flows in the Salt Fork Red River. Well withdrawals in these scenarios, unlike in the EPS scenarios, used historical well withdrawal rates (or multipliers on historical well withdrawal rates) and historical well locations used in the transient simulation of the calibrated numerical model. The effects of modified well withdrawals were evaluated by quantifying differences in groundwater storage and base flow in four 50-year scenarios, which applied (1) no groundwater pumping, (2) mean pumping rates for the study period (1980-2015), (3) 2015 pumping rates, and (4) increasing demand pumping rates at simulated wells. The increasing demand pumping rates assumed a cumulative 20.4-percent increase in pumping over 50 years based on 2010-60 demand projections for southwestern Oklahoma (OWRB, 2012b). Other model stresses were configured as the means of each monthly stress period from the calibrated model, and the scenarios assumed that future climate conditions were comparable to the 1980-2015 study period. The simulated water table from the end of the calibrated numerical-model period (2015) was used as the starting water table in each projected pumping scenario covering the period 2016-65. Because the calibrated numerical model ended in a relatively wet year, the altitude of this starting water table was above its long-term mean. All projected pumping scenarios, therefore, required about 2-3 years to discharge that extra water and return to simulated storage and base flows that approximated their long-term mean values (figs. 33A, $B$ ).

Table 12. Equal-proportionate-share (EPS) pumping rates for the Salt Fork Red River aquifer, southwestern Oklahoma.

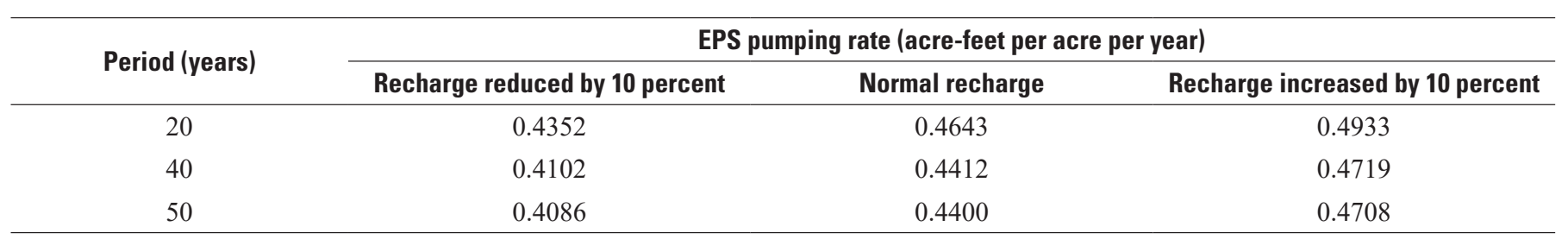



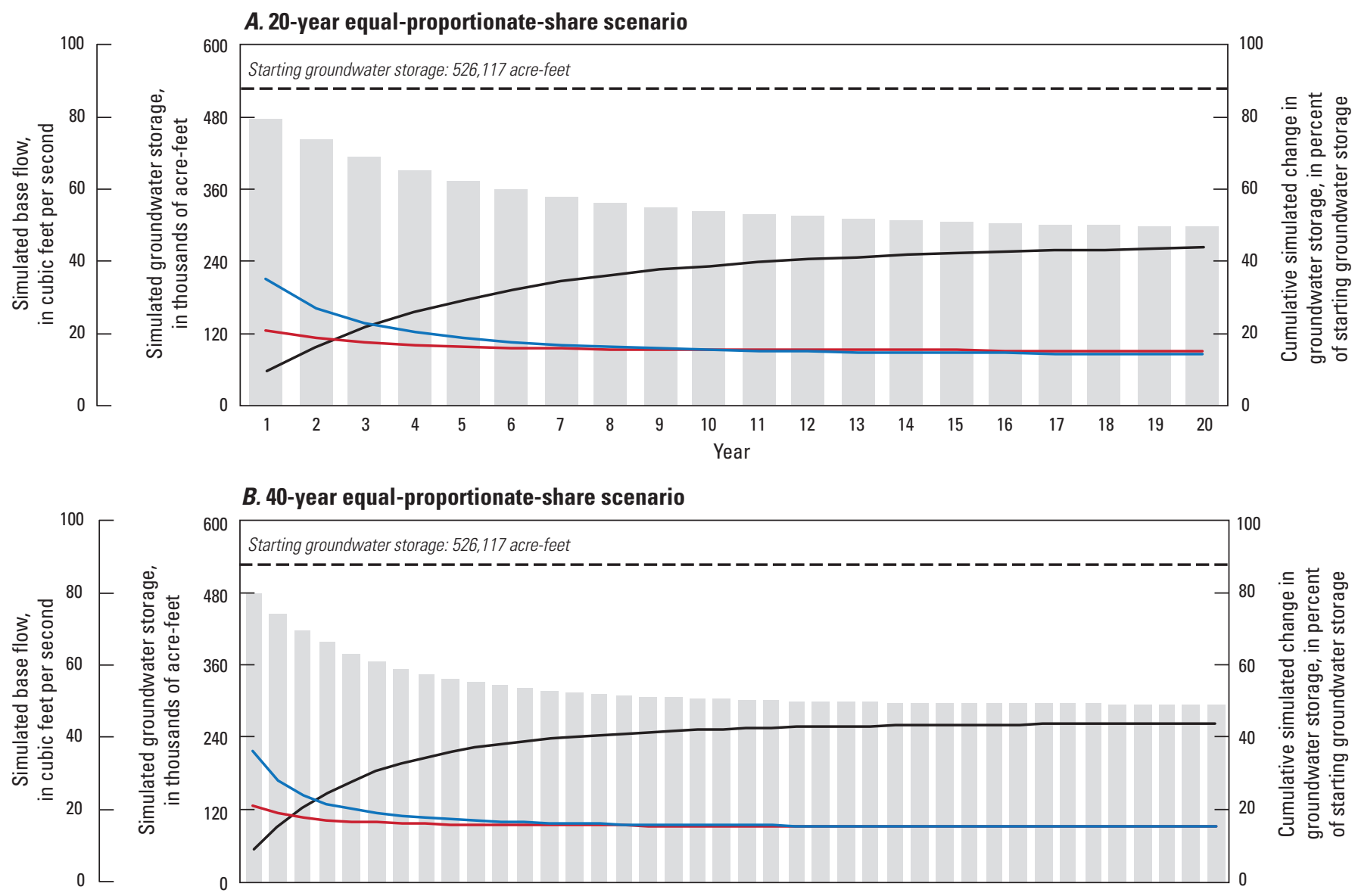

\section{B. 40-year equal-proportionate-share scenario}
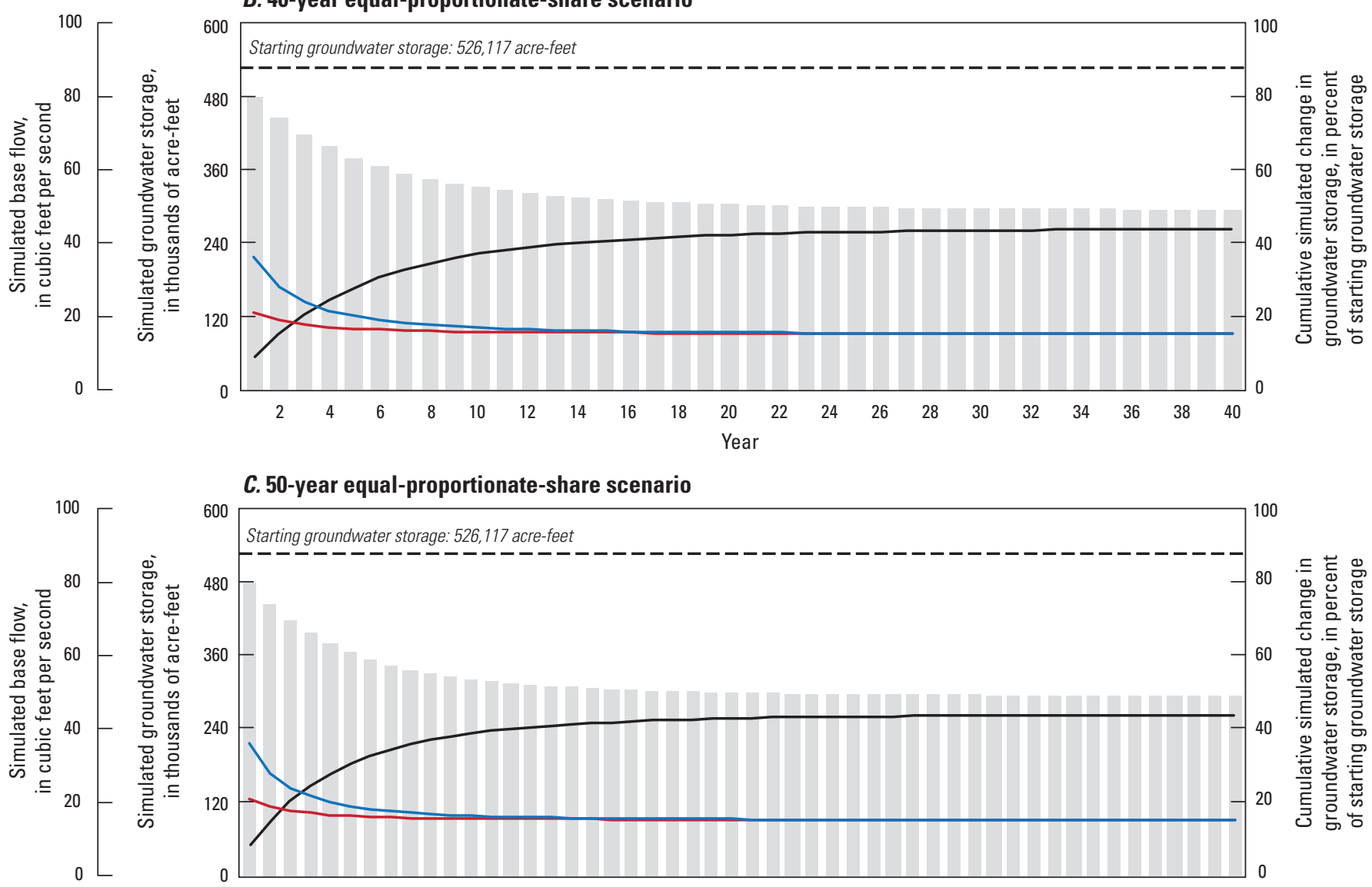

C. 50-year equal-proportionate-share scenario

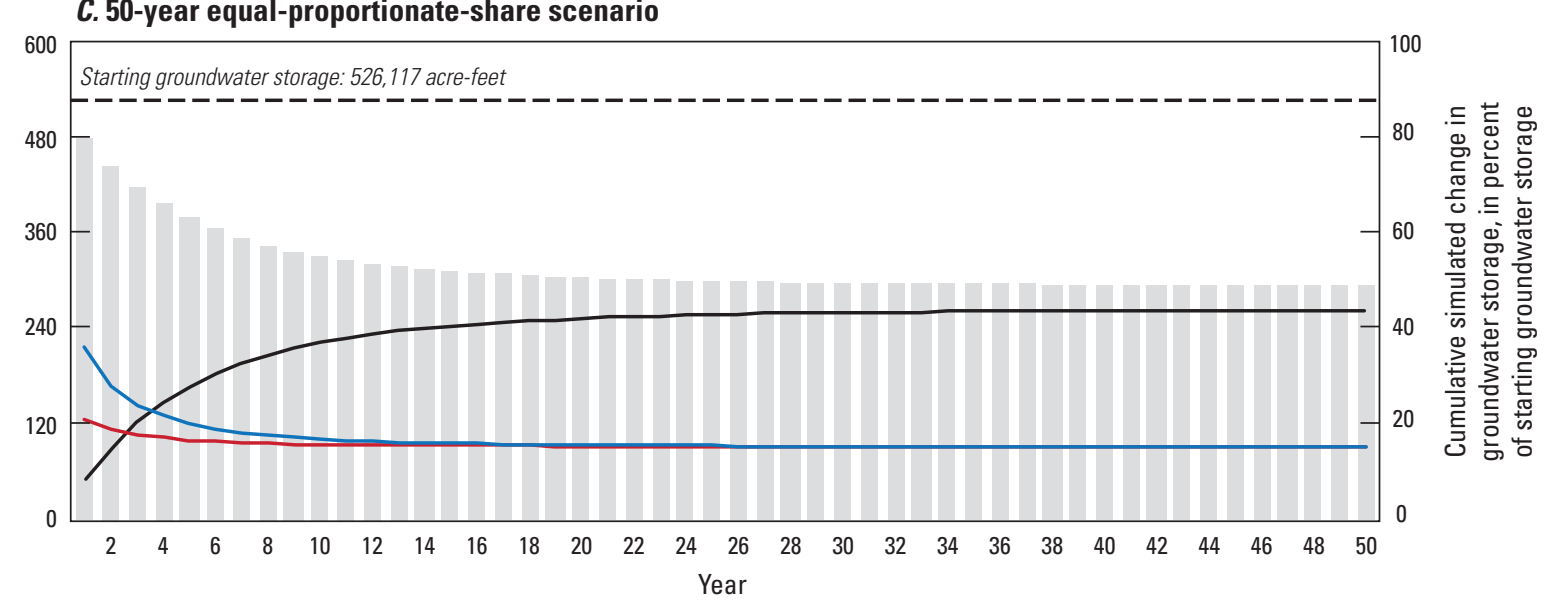

EXPLANATION

Simulated groundwater storage

Cumulative simulated change in groundwater storage

Simulated base flow at U.S. Geological Survey streamgage 07301110

Salt Fork Red River near Elmer, 0kla. (fig. 1, table 1)

- Simulated base flow at U.S. Geological Survey streamgage 07300500

Salt Fork Red River at Mangum, 0kla. (fig. 1, table 1)

Figure 31. Changes in simulated base flow and simulated groundwater storage during $A, 20, B, 40$, and $C, 50$ years of continuous equal-proportionate-share groundwater pumping in the Salt Fork Red River aquifer, southwestern Oklahoma. 


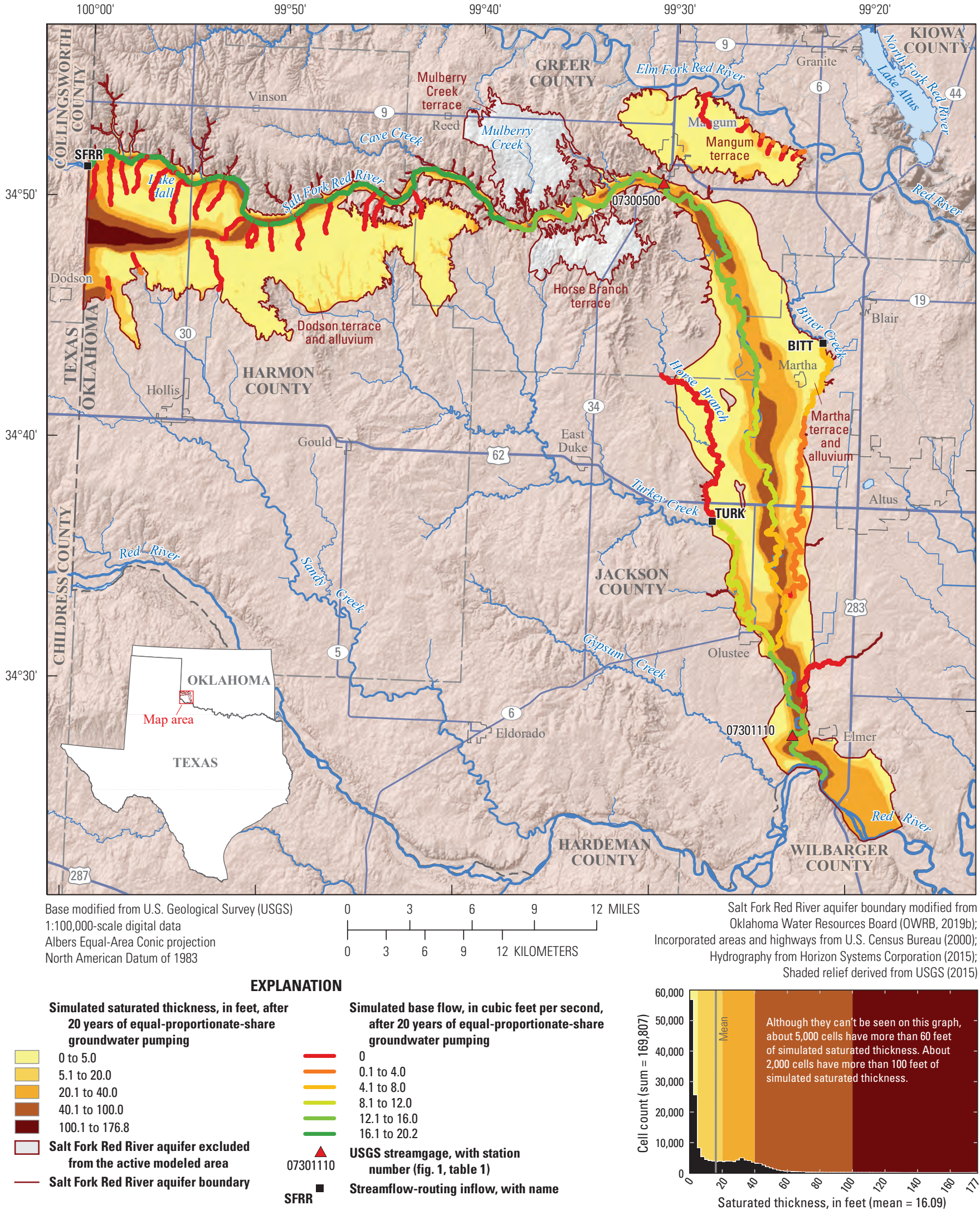

Figure 32. Simulated saturated thickness and base flow after 20 years of continuous equal-proportionate-share groundwater pumping in the Salt Fork Red River aquifer, southwestern Oklahoma. 


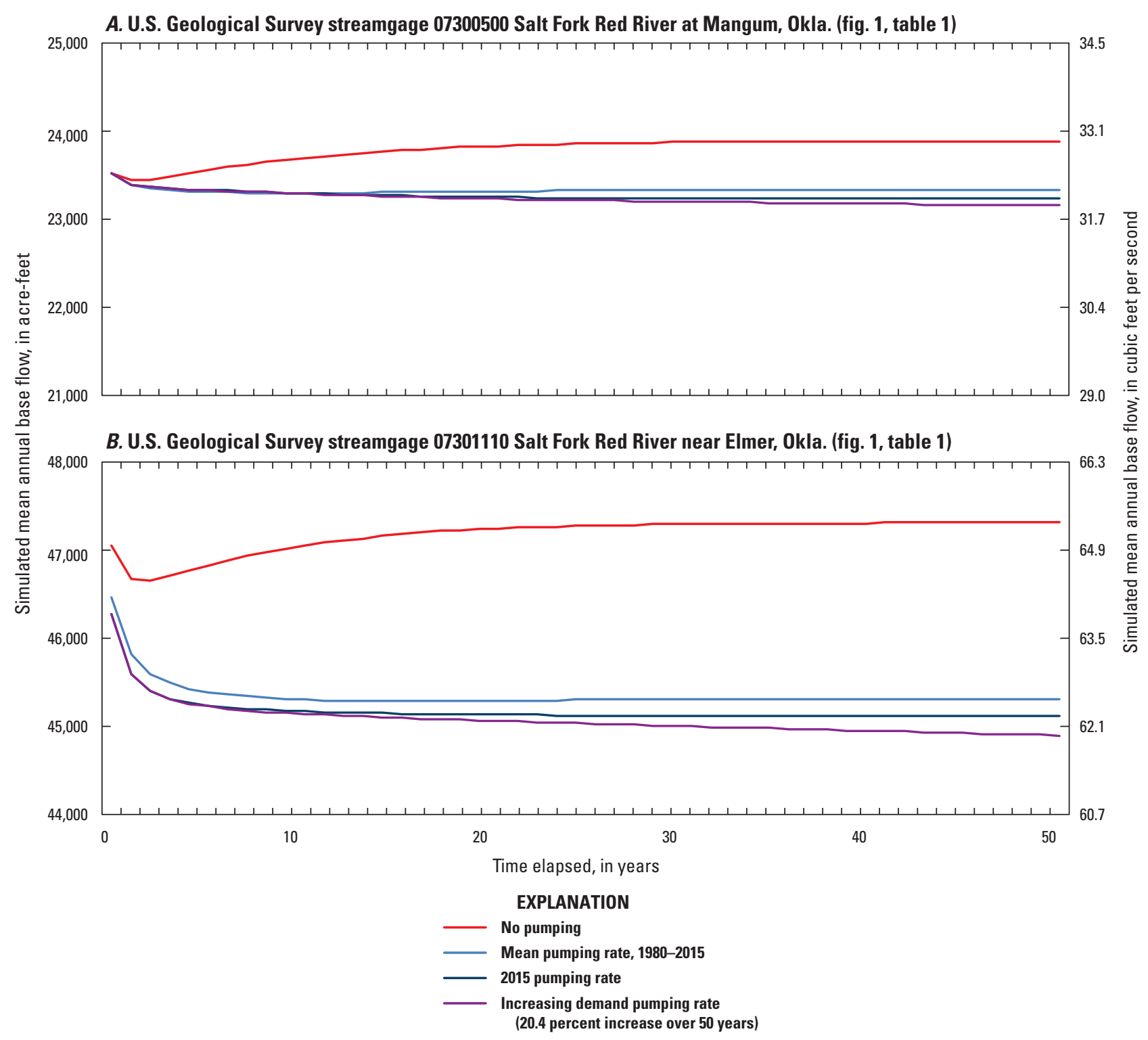

Figure 33. Simulated mean annual base flow at U.S. Geological Survey streamgages $A, 07300500$ Salt Fork Red River at Mangum, Okla., and $B, 07301110$ Salt Fork Red River near Elmer, Okla., through 50 years of groundwater pumping at selected rates in the Salt Fork Red River aquifer, southwestern Oklahoma.

Groundwater storage after 50 years with no pumping was 535,000 acre-ft, or 8,900 acre-ft (1.7 percent) greater than the initial groundwater storage; this groundwater storage increase is equivalent to a mean water-table-altitude increase of $0.48 \mathrm{ft}$ (table 13). Groundwater storage after 50 years of pumping at the mean rate for the study period (1980-2015) was 519,900 acre-ft, or 6,200 acre-ft (1.2 percent) less than the initial groundwater storage; this groundwater storage decrease is equivalent to a mean water-table-altitude decline of $0.34 \mathrm{ft}$. Groundwater storage at the end of the 50-year period with the 2015 pumping rates was 513,100 acre-ft, or 13,000 acre- $\mathrm{ft}$ (2.5 percent) less than the initial storage; this groundwater storage decrease is equivalent to a mean water-table-altitude decline of $0.71 \mathrm{ft}$. Groundwater storage at the end of the 50-year period with the increasing demand pumping rates was 509,700 acre-ft, or 16,500 acre-ft (3.1 percent) less than the initial storage; this groundwater storage decrease is equivalent to a mean water-table-altitude decline of $0.89 \mathrm{ft}$.

\section{Hypothetical 10-Year Drought}

A hypothetical 10-year drought scenario was used to simulate the effects of a prolonged period of reduced recharge on groundwater storage. The period January $1983-$ December 1992 was chosen as the simulated drought period. Drought effects were quantified by comparing the results of the drought scenario to those of the calibrated numerical 
Table 13. Changes in groundwater storage after 50 years of groundwater pumping at selected rates at simulated wells for the Salt Fork Red River aquifer, southwestern Oklahoma.

[Sy, specific yield]

\begin{tabular}{|c|c|c|c|c|c|}
\hline $\begin{array}{l}\text { 50-year projected pumping } \\
\text { scenario }\end{array}$ & $\begin{array}{c}\text { Groundwater } \\
\text { storage at begin- } \\
\text { ning of scenario, in } \\
\text { acre-feet }\end{array}$ & $\begin{array}{l}\text { Groundwater } \\
\text { storage at end } \\
\text { of scenario, in } \\
\text { acre-feet }\end{array}$ & $\begin{array}{l}\text { Change in ground- } \\
\text { water storage, in } \\
\text { acre-feet }\end{array}$ & $\begin{array}{l}\text { Change in } \\
\text { groundwater } \\
\text { storage, in } \\
\text { percent }\end{array}$ & $\begin{array}{c}\text { Mean change in water- } \\
\text { table altitude, in feet } \\
\text { (using calibrated Sy of } \\
0.1182 \text { ) }\end{array}$ \\
\hline No pumping & 526,100 & 535,000 & 8,900 & 1.7 & 0.48 \\
\hline $\begin{array}{l}\text { Mean pumping rates, } \\
1980-2015\end{array}$ & 526,100 & 519,900 & $-6,200$ & -1.2 & -0.34 \\
\hline $\begin{array}{l}\text { Increasing demand pumping } \\
\text { rates (20.4-percent total } \\
\text { increase) }\end{array}$ & 526,100 & 509,700 & $-16,500$ & -3.1 & -0.89 \\
\hline
\end{tabular}

model (no drought) at the end of the simulated drought period (1992). To simulate the hypothetical drought, recharge in the calibrated numerical model was reduced by 50 percent during the simulated drought period (1983-92), and upstream inflows from the Salt Fork Red River, Turkey Creek, and Bitter Creek were reduced by 75 percent, which was comparable to the reduction in Salt Fork Red River base flows at the Wellington gage during the 2011-14 drought period.

Groundwater storage at the end of the drought period (stress period 157) was 479,200 acre-ft, or 53,200 acre-ft (10.0 percent) less than the groundwater storage of the calibrated numerical model at the end of the drought period (table 14, fig. 34). This decrease in groundwater storage is equivalent to a mean water-table-altitude decline of $2.9 \mathrm{ft}$ (table 14). The largest water-table-altitude declines occurred in the terrace areas most upgradient from the Salt Fork Red River. The saturated thickness of areas near the Salt Fork Red River and major tributaries changed little during the hypothetical drought, but the simulated base flow in streams in those areas decreased rapidly. After 12 months of the hypothetical drought, simulated base flows at the Mangum and Elmer gages had both de9creased by greater than 50 percent as compared to the calibrated numerical model (figs. $35 A, B$ ). At the end of the 10-year hypothetical drought period (120 months), simulated base flows at the Mangum and Elmer gages had decreased by about 80 and 70 percent, respectively (figs. $35 A, B$ ).

\section{Model Limitations}

Some assumptions and simplifications were necessary in the simulation of groundwater flow. The use of the MODFLOW code requires the assumptions that groundwater flows are governed by Darcy's Law (Darcy, 1856), water is incompressible and of uniform density, and the aquifer hydrogeology can be simulated appropriately by the cell size and number of layers present. Computing and time limitations prevented the use of cell sizes that could better represent the true variability of the hydrogeologic characteristics; therefore, results generated by the model may be more applicable to a regional, rather than local, area.

No water-table-altitude observations were available near the beginning of the numerical-model period (1980), so the steady-state simulation was calibrated to mean water-tablealtitude observations from the transient period at each observation well. An uneven spatial and temporal distribution of water-table-altitude observations caused large data gaps in the calibration data (fig. 23A). Although the simulated water table in areas with fewer observations fell within an expected watertable-altitude range, more site-specific and local calibrationtarget data could facilitate a more detailed characterization of water-table conditions. Additionally, base-flow gain to the Salt Fork Red River is based on the simulated water table and may not be accurately represented in locations where water-tablealtitude observation data were relatively sparse.

Table 14. Change in groundwater storage after a hypothetical 10-year drought for the Salt Fork Red River aquifer, 1983-92.

[Sy, specific yield]

\begin{tabular}{|c|c|c|c|c|c|}
\hline Scenario & $\begin{array}{l}\text { Groundwater storage } \\
\text { of calibrated model } \\
\text { (1992), in acre-feet }\end{array}$ & $\begin{array}{l}\text { Groundwater storage } \\
\text { at end of scenario } \\
\text { (1992), in acre-feet }\end{array}$ & $\begin{array}{l}\text { Change in ground- } \\
\text { water storage, } \\
\text { 1983-92, in acre-feet }\end{array}$ & $\begin{array}{l}\text { Change in ground- } \\
\text { water storage, } \\
1983-92 \text {, in percent }\end{array}$ & $\begin{array}{c}\text { Mean change in } \\
\text { water-table altitude, } \\
\text { in feet (using cali- } \\
\text { brated Sy of 0.1182) }\end{array}$ \\
\hline
\end{tabular}


Months after beginning of simulated drought (add 37 for stress-period number)

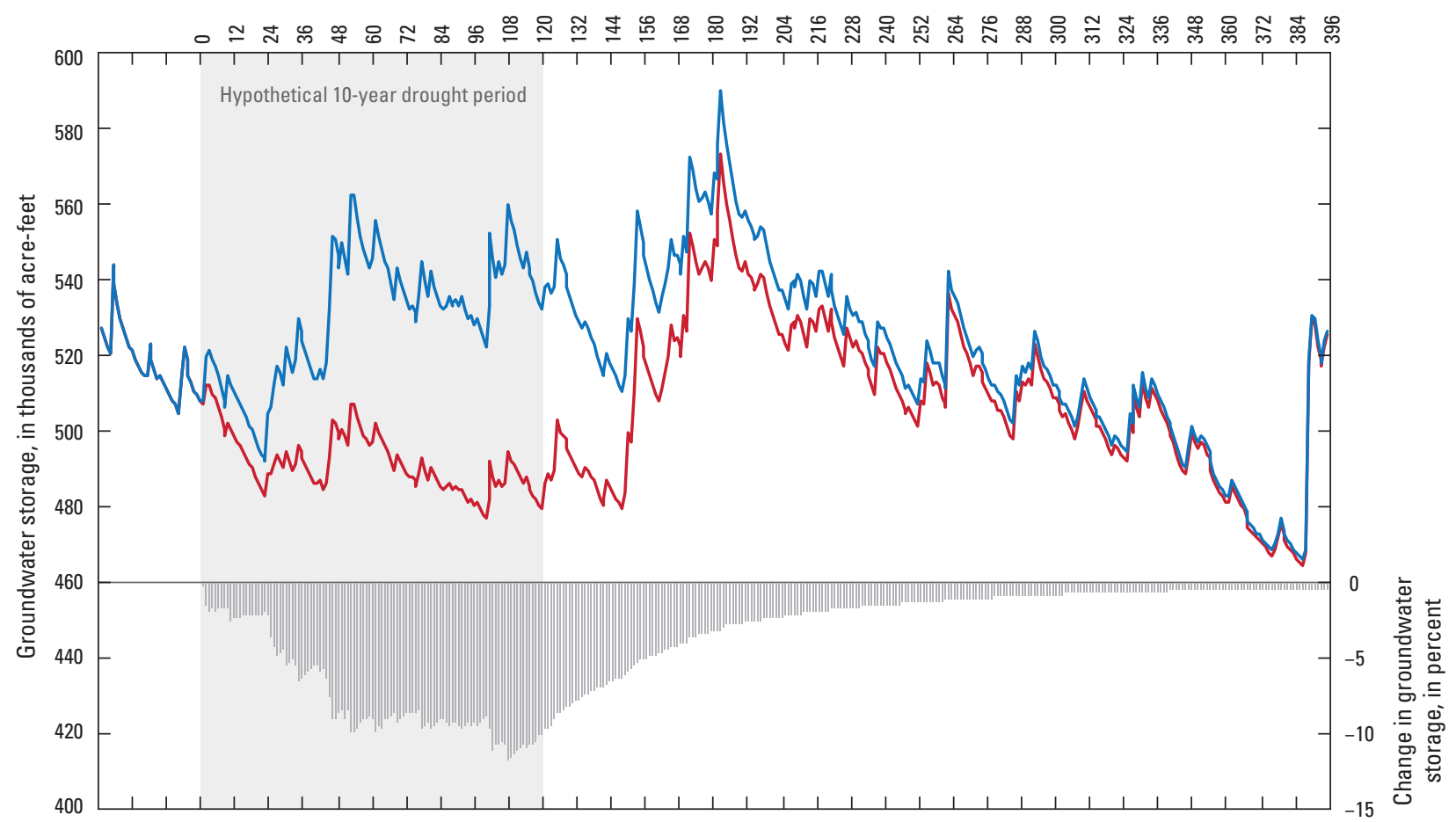

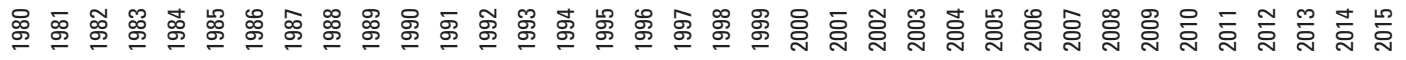

Year

\section{EXPLANATION}

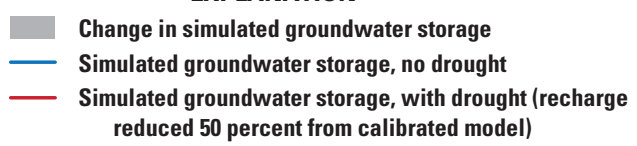

Figure 34. Changes in simulated groundwater storage resulting from a hypothetical 10-year drought (1983-92) for the Salt Fork Red River aquifer, southwestern Oklahoma.

The edges of most of the active modeled area, including the bottoms of active cells, were simulated as no-flow boundaries. This practice is commonplace in numerical-model simulations, but it is a simplification that, given the large number of cells involved, likely adds uncertainty to the results described in this report. The stream network used in the numerical model also is a simplification of the actual stream geometry and hydraulic properties. Refined measurement of the stream channel width and streambed conductivity at the local scale could improve the numerical-model calibration because these factors control the amount of streambed seepage exchange with the aquifer. The numerical model was calibrated primarily to baseflow estimates; therefore, collection of more streamflow data during other hydrologic conditions also could further reduce uncertainty in local-scale simulation results.

Exact amounts of annual groundwater use are unknown because groundwater wells are not metered, and groundwateruse data are based on estimates submitted to the OWRB by permit holders. Additionally, groundwater use by domestic wells, though assumed to be relatively small, was not included in the numerical model. 
A. U.S. Geological Survey streamgage 07300500 Salt Fork Red River at Mangum, 0kla. (fig. 1, table 1)

Months after beginning of simulated drought (add 37 for stress-period number)

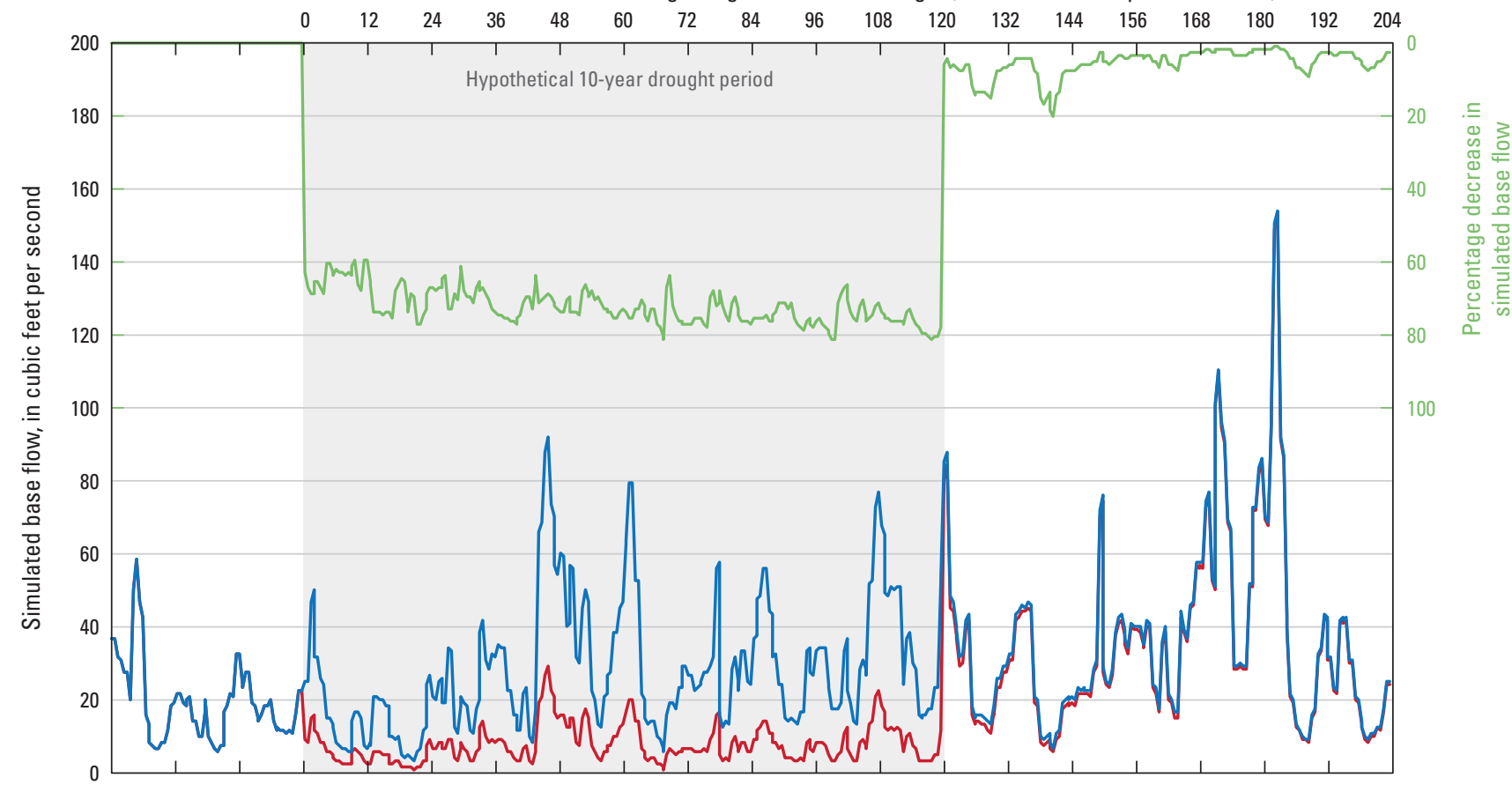

B. U.S. Geological Survey streamgage 07301110 Salt Fork Red River near Elmer, Okla. (fig. 1, table 1)

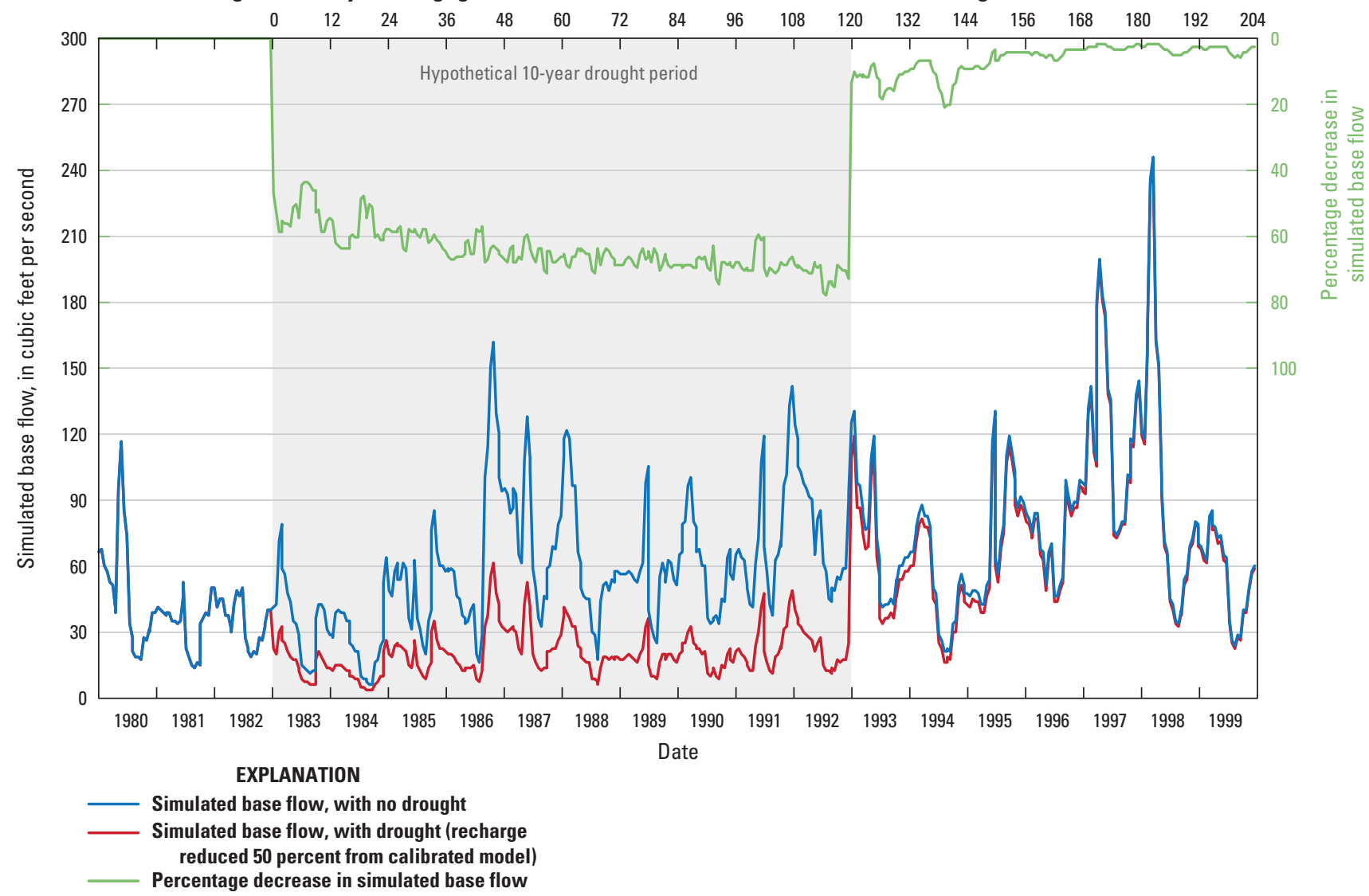

Figure 35. Changes in simulated base flow at U.S. Geological Survey streamgages $A, 07300500$ Salt Fork Red River at Mangum, Okla., and $B, 07301110$ Salt Fork Red River near Elmer, Okla., resulting from a hypothetical 10-year drought (1983-92) for the Salt Fork Red River aquifer, southwestern Oklahoma. 


\section{Summary}

The 1973 Oklahoma Water Law (82 OK Stat § 82-1020.5) requires that the Oklahoma Water Resources Board (OWRB) conduct hydrologic investigations of the State's groundwater basins to support a determination of the maximum annual yield for each groundwater basin (hereinafter referred to as an "aquifer"). The maximum annual yield allocated per acre of land is known as the equal-proportionateshare (EPS) pumping rate. At present (2021), the OWRB has not yet established a maximum annual yield and EPS pumping rate for the Salt Fork Red River aquifer. To provide updated information to the OWRB that could support evaluation and determination of an appropriate maximum annual yield, the U.S. Geological Survey (USGS), in cooperation with the OWRB, conducted a hydrologic investigation and evaluated the effects of potential groundwater withdrawals on groundwater availability in the Salt Fork Red River aquifer.

The purpose of this report is to describe a hydrologic investigation of the Salt Fork Red River aquifer that included (1) an updated summary of the hydrogeology with a definition of a hydrogeologic framework of the aquifer, (2) development of conceptual and calibrated numerical groundwater-flow models for the aquifer representing the period 1980-2015, and (3) results of simulations of groundwater availability obtained by using the calibrated numerical groundwater-flow model. The geographic scope of the hydrologic investigation is the extent of alluvium and terrace deposits that compose the Salt Fork Red River aquifer. Although the alluvium and terrace deposits of the Salt Fork Red River extend into Texas (where they are known as the Seymour aquifer), this investigation was focused exclusively on the OWRB jurisdictional extent of the Salt Fork Red River aquifer in southwestern Oklahoma. The Salt Fork Red River aquifer in Greer, Harmon, and Jackson Counties of southwestern Oklahoma is composed of about 274.5 square miles of alluvium and terrace deposits associated with the Salt Fork Red River.

The mean annual recharge rate to the Salt Fork Red River aquifer for the period 1980-2015 was estimated to be about 2.94 inches per year, or 10.0 percent of the mean annual precipitation for the same period (29.4 inches per year). This 1980-2015 mean annual recharge rate is equivalent to a mean annual recharge rate of about 38,000 acre-feet per year (acre-ft/yr) for the Salt Fork Red River aquifer excluding about 19,764 acres comprising the Mulberry Creek and Horse Creek terraces. The mean annual recharge rates upgradient and downgradient from USGS streamgage 07300500 Salt Fork Red River at Mangum, Okla. (hereinafter referred to as the "Mangum gage"), apportioned by aquifer area (41.5 and 58.5 percent, respectively), were about 16,000 and $22,000 \mathrm{acre}-\mathrm{ft} / \mathrm{yr}$, respectively. Mean annual groundwater use for the study period (1980-2015) was 3,532.7 acre-ft/yr; about 77 percent of that groundwater use was for irrigation, and about 23 percent was for public supply. Most groundwater use for irrigation was associated with wells in the Martha terrace.
The numerical groundwater-flow model of the Salt Fork Red River aquifer was constructed by using MODFLOW-2005 with the Newton formulation solver. The model of the Salt Fork Red River aquifer was spatially discretized into 1,050 rows, 1,125 columns, about 170,000 active cells measuring 200 by 200 feet (ft), and a single convertible layer. The model was temporally discretized into 432 monthly transient stress periods (each with two time steps to improve model stability). An initial steady-state stress period represented mean annual inflows to, and outflows from, the aquifer and produced a solution that was used as the initial condition for subsequent transient stress periods as well as some groundwater-availability scenarios. The model was calibrated to water-table-altitude observations at selected wells and base-flow observations at selected streamgages.

The simulated saturated thickness of the Salt Fork Red River aquifer was determined by subtracting the altitude of the aquifer base from the simulated water-table altitude at the end of the numerical-model period (2015). The simulated saturated thickness was more than $75 \mathrm{ft}$ in a paleochannel in the Dodson terrace near the Texas border. The mean aquifer thickness (sum of saturated and unsaturated) was $49.62 \mathrm{ft}$, and the mean saturated thickness was $28.55 \mathrm{ft}$. A simulated mean transmissivity of 1,024 feet squared per day was computed from the calibrated hydraulic conductivity and saturated thickness of each cell. The simulated available water in storage at the end of the numerical-model period (2015) was 526,117 acre-feet (acre-ft); about 42 percent of that total was available upgradient from the Mangum gage, and about 58 percent of that total was available downgradient from the Mangum gage.

Three types of groundwater-availability scenarios were run using the calibrated numerical model. These scenarios were used to (1) estimate the EPS pumping rate that ensures a minimum 20-, 40-, and 50-year life of the aquifer, (2) quantify the potential effects of projected well withdrawals on groundwater storage over a 50-year period, and (3) simulate the potential effects of a hypothetical 10-year drought on base flow and groundwater storage. The 20-, 40-, and 50-year EPS pumping rates under normal recharge conditions were about $0.46,0.44$, and 0.44 acre-ft per acre per year, respectively. Given the 155,929-acre modeled aquifer area, these rates correspond to annual yields of about $71,700,68,600$, and 68,600 acre-ft/yr, respectively. For the 20-year EPS scenario, decreasing and increasing recharge by 10 percent resulted in a 6-percent change in the EPS pumping rate in both cases; for the 40- and 50-year EPS scenarios, decreasing and increasing recharge by 10 percent resulted in a 7-percent change in the EPS pumping rate in both cases.

Projected 50-year pumping scenarios were used to simulate the effects of selected well withdrawal rates on groundwater storage of the Salt Fork Red River aquifer and base flows in the Salt Fork Red River. The effects of well withdrawals were evaluated by quantifying differences in groundwater storage and base flow in four 50-year scenarios, which applied (1) no groundwater pumping, (2) mean pumping rates for the study period (1980-2015), (3) 2015 pumping rates, and 
(4) increasing demand pumping rates at simulated wells. The increasing demand pumping rates assumed a cumulative 20.4-percent increase in pumping over 50 years based on 2010-60 demand projections for southwestern Oklahoma. Groundwater storage after 50 years with no pumping was 535,000 acre-ft, or 8,900 acre-ft (1.7 percent) greater than the initial groundwater storage; this groundwater storage increase is equivalent to a mean water-table-altitude increase of $0.48 \mathrm{ft}$. Groundwater storage after 50 years of pumping at the mean rate for the study period (1980-2015) was 519,900 acre-ft, or 6,200 acre-ft (1.2 percent) less than the initial groundwater storage; this groundwater storage decrease is equivalent to a mean water-table-altitude decline of $0.34 \mathrm{ft}$. Groundwater storage at the end of the 50-year period with 2015 pumping rates was 513,100 acre-ft, or 13,000 acre-ft (2.5 percent) less than the initial storage; this groundwater storage decrease is equivalent to a mean water-table-altitude decline of $0.71 \mathrm{ft}$. Groundwater storage at the end of the 50-year period with increasing demand pumping rates was 509,700 acre-ft, or 16,500 acre-ft (3.1 percent) less than the initial storage; this groundwater storage decrease is equivalent to a mean watertable-altitude decline of $0.89 \mathrm{ft}$.

A hypothetical 10-year drought scenario was used to simulate the effects of a prolonged period of reduced recharge on groundwater storage. The period January 1983December 1992 was chosen as the simulated drought period. Drought effects were quantified by comparing the results of the drought scenario to those of the calibrated numerical model (no drought) at the end of the simulated drought period (1992). To simulate the hypothetical drought, recharge in the calibrated numerical model was reduced by 50 percent during the simulated drought period (1983-92). Upstream inflows from the Salt Fork Red River, Turkey Creek, and Bitter Creek were reduced by 75 percent. Groundwater storage at the end of the drought period (1992) was 479,200 acre-ft, or 53,200 acre-ft (10.0 percent) less than the groundwater storage of the calibrated numerical model at the end of the drought period. This decrease in groundwater storage is equivalent to a mean water-table-altitude decline of $2.9 \mathrm{ft}$. At the end of the 10-year hypothetical drought period, simulated base flows at the Mangum gage and USGS streamgage 07301110 Salt Fork Red River near Elmer, Okla., had decreased by about 80 and 70 percent, respectively.

\section{References Cited}

Adams, G.P., and Bergman, D.L., 1996, Geohydrology of alluvium and terrace deposits of the Cimarron River from Freedom to Guthrie, Oklahoma: U.S. Geological Survey Water-Resources Investigations Report 95-4066, 57 p., accessed June 5, 2020, at https://doi.org/10.3133/ wri954066.
Alder, J.R., and Hostetler, S.W., 2013, CMIP5 Global Climate Change Viewer: U.S. Geological Survey online application, accessed June 30, 2017, at http://regclim.coas.oregonstate.edu/gccv/index.html.

Arnold, L.R., 2011, Estimates of deep-percolation return flow beneath a flood- and a sprinkler-irrigated site in Weld County, Colorado, 2008-2009: U.S. Geological Survey Scientific Investigations Report 2011-5001, 225 p., accessed June 5, 2020, at https://doi.org/10.3133/ $\operatorname{sir} 20115001$.

Barclay, J.E., and Burton, L.C., 1953, Ground-water resources of the terrace deposits and alluvium of western Tillman County, Oklahoma: Oklahoma Planning and Resources Board, Division of Water Resources Bulletin 12, 71 p.

Bard, P.Y., and SESAME-Team, 2004, Guidelines for the implementation of the $\mathrm{H} / \mathrm{V}$ spectral ratio technique on ambient vibrations-measurements, processing and interpretations: SESAME European research project EVG1CT-2000-00026, deliverable D23.12.

Barlow, P.M., Cunningham, W.L., Zhai, T., and Gray, M., 2015, U.S. Geological Survey groundwater toolbox, a graphical and mapping interface for analysis of hydrologic data (version 1.0)-User guide for estimation of base flow, runoff, and groundwater recharge from streamflow data: U.S. Geological Survey Techniques and Methods 3-B10, 27 p., accessed June 5, 2020, at https://doi.org/ 10.3133/tm3B10.

Barlow, P.M., and Leake, S.A., 2012, Streamflow depletion by wells - Understanding and managing the effects of groundwater pumping on streamflow: U.S. Geological Survey Circular 1376, 84 p., accessed June 5, 2020, at https://doi.org/10.3133/cir1376.

Bureau of Reclamation, 2005, Appraisal report-Water supply augmentation, W.C. Austin Project, Oklahoma: U.S. Department of the Interior, Bureau of Reclamation, Oklahoma-Texas Area Office, accessed February 19, 2020, at https://www.usbr.gov/gp/otao/wcaustin2005.pdf.

Burton, L.C., 1965, Ground water in terrace deposits of central Beckham County, Oklahoma: Oklahoma Water Resources Board Bulletin 25, 30 p.

Chandler, V.W., and Lively, R.S., 2014, Evaluation of the horizontal-to-vertical spectral ratio (HVSR) passive seismic method for estimating the thickness of Quaternary deposits in Minnesota and adjacent parts of Wisconsin: Minnesota Geological Survey Open File Report 14-01, 52 p.

Cleveland, W., 1979, Robust locally weighted regression and smoothing scatterplots: Journal of the American Statistical Association, v. 74, no. 368, p. 829-836. [Also available at https://doi.org/10.1080/01621459.1979.10481038.] 
Cowardin, L.M., Carter, V., Golet, F.C., and LaRoe, E.T., 1979, Classification of wetlands and deepwater habitats of the United States: Washington, D.C., U.S. Department of the Interior, U.S. Fish and Wildlife Service, FWS/ OBS-79/31.

Cunningham, W.L., and Schalk, C.W., 2011, Groundwater technical procedures of the U.S. Geological Survey: U.S. Geological Survey Techniques and Methods 1-A1, 151 p., accessed June 5, 2020, at https://doi.org/10.3133/tm1A1.

Darcy, H., 1856, Les Fontances publiques de la ville de Dijon: Paris, Victor Dalmont, 668 p.

Doherty, J., 2010, PEST, model independent parameter estimation-User manual (5th ed.): Brisbane, Australia, Watermark Numerical Computing, accessed September 24, 2015, at https://pesthomepage.org/Downloads.php.

Domenico, P.A., and Schwartz, F.W., 1998, Physical and chemical hydrology: New York, John Wiley \& Sons, 824 p.

Ellis, J.H., 2018, Simulation of groundwater flow and analysis of projected water use for the Rush Springs aquifer, western Oklahoma: U.S. Geological Survey Scientific Investigations Report 2018-5136, 156 p., accessed June 5, 2020, at https://doi.org/10.3133/sir20185136.

Ellis, J.H., Mashburn, S.L., Graves, G.M., Peterson, S.M., Smith, S.J., Fuhrig, L.F., Wagner, D.L., and Sanford, J.E., 2017, Hydrogeology and simulation of groundwater flow and analysis of projected water use for the Canadian River alluvial aquifer, western and Central Oklahoma: U.S. Geological Survey Scientific Investigations Report 2016-5180, 64 p., accessed June 30, 2017, at https://doi.org/ $10.3133 / \operatorname{sir} 20165180$.

Esri, Inc., 2017, How IDW works-ArcGIS for desktop help: Redlands, Calif., Esri, Inc., accessed March 24, 2017, at https://desktop.arcgis.com/en/arcmap/10.3/tools/3d-analysttoolbox/how-idw-works.htm.

Ewing, J.E., Jones, T.L., Pickens, J.F., Chastain-Howley, A., Dean, K.E., and Spear, A.A., 2004, Groundwater availability model for the Seymour aquifer: Texas Water Development Board Contract Report, 533 p., accessed June 30, 2017, at https://www.twdb.texas.gov/groundwater/ models/gam/symr/SYMR_Model_Report.pdf.

Fabian, R.S., 1986, Hydrologic investigation of the Salt Fork of the Red River: Oklahoma Water Resources Board Technical Report 86-2, 16 p.

Fetter, A.W., 1994, Applied hydrogeology 3rd ed.: Upper Saddle River, N.J., Prentice-Hall, 691 p.
Folk, R.L., and Ward, W.C., 1957, Brazos River bar-A study in the significance of grain size parameters: Journal of Sedimentary Petrology, v. 27, no. 1, p. 3-26. [Also available at https://doi.org/10.1306/74D70646-2B21-11D78648000102C1865D.]

Fry, J.A., Xian, G., Jin, S., Dewitz, J.A., Homer, C.G., Yang, L., Barnes, C.A., Herold, N.D., and Wickham, J.D., 2011, Completion of the 2006 National Land Cover Database for the conterminous United States: Photogrammetric Engineering and Remote Sensing, v. 77, no. 9, p. 858-864.

Gee, G.W., and Or, D., 2002, Particle-size analysis, in Dane, J.H., and Topp, G.C., eds., Methods of soil analysis - Part 4, physical methods: Madison, Wisc., Soil Science Society of America, p. 255-294.

Geoprobe Systems, 2011, Geoprobe Macro-Core MC5Standard operating procedure: Salina, Kans., Kejr, Inc., Technical Bulletin MK3139, accessed July 31, 2017, at https://geoprobe.com/sites/default/files/storage/pdfs/mc5 sop_mk3139_0111-withmobilecode_0_0.pdf.

Geoprobe Systems, 2015, Geoprobe ${ }^{\circledR}$ Hydraulic Profiling Tool (HPT) system, standard operating procedure: Salina, Kans., Kejr, Inc., Technical Bulletin MK3137, 22 p., accessed March 14, 2017, at https://geoprobe.com/literature/hpt-sop.

Geoprobe Systems, 2020, Direct Image Viewer user guide (rev. 2.0): Salina, Kans., Kejr, Inc., accessed July 31, 2020, at https:/geoprobe.com/sites/default/files/storage/pdfs/ DI\%20Viewer\%20User\%20Guide\%20Rev.2.0.pdf.

Harbaugh, A.W., 1990, A computer program for calculating subregional water budgets using results from the U.S. Geological Survey modular three-dimensional groundwaterflow model: U.S. Geological Survey Open-File Report 90-392, 46 p., accessed June 5, 2020, at https://doi.org/ $10.3133 /$ ofr90392.

Harbaugh, A.W., 2005, MODFLOW-2005, The U.S. Geological Survey modular ground-water model-The ground-water flow process: U.S. Geological Survey Techniques and Methods 6-A16 [variously paged], accessed June 5, 2020, at https://doi.org/10.3133/tm6A16.

Harbaugh, A.W., Banta, E.R., Hill, M.C., and McDonald, M.G., 2000, MODFLOW-2000, the U.S. Geological Survey modular groundwater model-User guide to modularization concepts and the groundwater flow process: U.S. Geological Survey Open-File Report 00-92, 121 p., accessed June 5, 2020, at https://doi.org/10.3133/ofr200092.

Hargreaves, G.H., and Samani, Z.A., 1985, Reference crop evapotranspiration from temperature: Applied Engineering in Agriculture, v. 1, no. 2, p. 96-99. [Also available at https://doi.org/10.13031/2013.26773.] 
Hazen, A., 1911, Discussion-Dams on sand foundations: Transactions of the American Society of Civil Engineers, v. 73 , p. 199-203.

Healy, R.W., and Cook, P.G., 2002, Using groundwater levels to estimate recharge: Hydrogeology Journal, v. 10, no. 1, p. 91-109. [Also available at https://doi.org/10.1007/ s10040-001-0178-0.]

Hill, M.C., Banta, E.R., Harbaugh, A.W., and Anderman, E.R., 2000, MODFLOW-2000, the U.S. Geological Survey modular ground-water model-User guide to the observation, sensitivity, and parameter-estimation processes and three post-processing programs: U.S. Geological Survey Open-File Report 00-184, 210 p., accessed June 5, 2020, at https://doi.org/10.3133/ofr00184.

Hill, M.C., and Tiedeman, C.R., 2007, Effective groundwater model calibration - With analysis of data, sensitivities, predictions, and uncertainty: New York, Wiley and Sons, 455 p. [Also available at https://doi.org/10.1002/0470041080.]

Hollowell, J.R., 1965a, Ground water in the alluvium of Otter Creek basin, Oklahoma: Oklahoma Water Resources Board Bulletin 27, $15 \mathrm{p}$.

Hollowell, J.R., 1965b, Ground water in the alluvium of Elk Creek basin, Oklahoma: Oklahoma Water Resources Board Bulletin 28, $12 \mathrm{p}$.

Horizon Systems Corporation, 2015, National Hydrography Dataset Plus (NHDPlus): Horizon Systems Corporation, accessed November 1, 2010, at https://nhdplus.com/ NHDPlus/.

Johnson, K.S., ed., 1990, Hydrogeology and karst of the Blaine gypsum-dolomite aquifer, southwestern Oklahoma: Oklahoma Geological Survey Special Publication 90-5, 31 p., accessed June 5, 2020, at http://ogs.ou.edu/docs/ specialpublications/SP90-5.pdf.

Johnson, K.S., ed., 1991, Map of aquifers and recharge areas in Oklahoma: Oklahoma Geological Survey Geologic Map 44, 1 sheet with supplement, 1:500,000 scale, accessed September 4, 2019, at https://ou.edu/content/dam/ogs/ documents/GMs/GM-44\%20map.pdf.

Kendall, M.G., 1938, A new measure of rank correlation: Biometrika, v. 30, no. 1-2, p. 81-93. [Also available at https://doi.org/10.1093/biomet/30.1-2.81.]

Kottek, M., Grieser, J., Beck, C., Rudolf, B., and Rubel, F., 2006, World map of the Köppen-Geiger climate classification updated: Meteorologische Zeitschrift (Berlin), v. 15, no. 3, p. 259-263, accessed June 30, 2017, at https://doi.org/ 10.1127/0941-2948/2006/0130.
Lewis, J.M., and Esralew, R.A., 2009, Statistical summaries of streamflow in and near Oklahoma through 2007: U.S. Geological Survey Scientific Investigations Report 2009-5135, 36 p., accessed June 5, 2020, at https://doi.org/ $10.3133 / \operatorname{sir} 20095135$.

Lubczynski, M.W., 2008, The hydrogeological role of trees in water-limited environments: Hydrogeology Journal, v. 17, no. 1, p. 247-259, accessed June 5, 2020, at https://doi.org/ 10.1007/s10040-008-0357-3.

Mandelbrot, B.B., 1983, The fractal geometry of nature: New York, W.H. Freeman, 468 p. [Also available at https://doi.org/10.1119/1.13295.]

Marsh, S., and Holland, A., 2016, Comprehensive fault database and interpretive fault map of Oklahoma: Oklahoma Geological Survey database, accessed March 22, 2019, at http://ogs.ou.edu/docs/openfile/OF2-2016S.zip.

Mashburn, S.L., Ryter, D.W., Neel, C.R., Smith, S.J., and Magers, J.S., 2013, Hydrogeology and simulation of groundwater flow in the Central Oklahoma (GarberWellington) aquifer, Oklahoma, 1987 to 2009, and simulation of available water in storage, 2010-2059: U.S. Geological Survey Scientific Investigations Report 2013-5219, 92 p., accessed June 5, 2020, at https://doi.org/ $10.3133 / \operatorname{sir} 20135219$.

Masoner, J.R., Mladinich, C.S., Konduris, A.M., and Smith, S.J., 2003, Comparison of irrigation water use estimates calculated from remotely sensed irrigated acres and State reported irrigated acres in the Lake Altus drainage basin, Oklahoma and Texas, 2000 growing season: U.S. Geological Survey Water-Resources Investigations Report 03-4155, 38 p., accessed June 5, 2020, at https://doi.org/ $10.3133 /$ wri034155.

McCall, W., 2010, Tech guide for calculation of estimated hydraulic conductivity (Est. K) log from HPT data: Salina, Kans., Kejr, Inc., 20 p., accessed March 14, 2017, at https://geoprobe.com/literature/tech-guide-for-estimating-kusing-hpt.

Microsoft Corporation, 2018, Bing maps imagery API, accessed May 30, 2018, at https://msdn.microsoft.com/enus/library/ff701721.aspx.

Multi-Resolution Land Characteristics Consortium, 2011, National Land Cover Database 2006 (NLCD 2006): MultiResolution Land Characteristics Consortium online database, accessed October 3, 2011, at https://www.mrlc.gov/ nlcd2006.php.

Munsell, A.H., 1912, A pigment color system and notation: The American Journal of Psychology, v. 23, no. 2, p. 236-244. [Also available at https://dx.doi.org/10.2307/ 1412843.] 
National Agricultural Statistics Service, 2015, Oklahoma agricultural statistics 2015: U.S. Department of Agriculture web page, accessed November 25, 2015, at https://www.nass.usda.gov/Statistics by State/Oklahoma/ Publications/Annual_Statistical_Bulletin/ok_bulletin 2015.pdf.

National Agricultural Statistics Service, 2019, CropScape, cropland data layers, 2010-17: U.S. Department of Agriculture online database, accessed June 30, 2019, at https://nassgeodata.gmu.edu/CropScape/.

National Climatic Data Center, 2019a, Climate data online: U.S. National Oceanic and Atmospheric Administration online database, accessed February 18, 2019, at https://www.ncdc.noaa.gov/cdo-web/.

National Climatic Data Center, 2019b, Retrieve data for division: U.S. National Oceanic and Atmospheric Administration online database, accessed July 20, 2019, at https://www7.ncdc.noaa.gov/CDO/ CDODivisionalSelect.jsp.

Natural Resources Conservation Service, 2015, Geospatial Data Gateway: U.S. Department of Agriculture online database, accessed March 14, 2015, at https://datagateway.nrcs.usda.gov/.

Neel, C.R., Wagner, D.L., Correll, J.S., Sanford, J.E., Hernandez, R.J., Spears, K.W., and Waltman, P.B., 2018, Hydrologic investigation report of the Rush Springs aquifer in west-central Oklahoma, 2015: Oklahoma Water Resources Board Publication 2018-01, 61 p., accessed June 5, 2020, at https://www.owrb.ok.gov/reports/studies/ RushSprings2015.pdf.

Niswonger, R.G., Panday, S., and Ibaraki, M., 2011, MODFLOW-NWT, A Newton formulation for MODFLOW-2005: U.S. Geological Survey Techniques and Methods, book 6, chap. A37, 44 p., accessed June 5, 2020, at https://doi.org/10.3133/tm6A37.

Niswonger, R.G., and Prudic, D.E., 2005, Documentation of the Streamflow-Routing (SFR2) package to include unsaturated flow beneath streams-A modification to SFR1: U.S. Geological Survey Techniques and Methods, book 6, chap. A13, 50 p., accessed June 5, 2020, at https://doi.org/ $10.3133 / \mathrm{tm} 6 \mathrm{~A} 13$.

Northcutt, R.A., and Campbell, J.A., 1995, Geologic provinces of Oklahoma: Oklahoma Geological Survey OpenFile Report 5-95, 1 sheet, scale 1:750,000, accessed June 5, 2020, at http://ogs.ou.edu/docs/openfile/OF5-95.pdf.

Oklahoma Climatological Survey, 2015, Average length of growing season: Oklahoma Climatological Survey web page, accessed November 25, 2015, at http://climate.ok.gov/ index.php/climate/map/average_length_of_growing_season/ oklahoma_south-central_u.s.
Oklahoma Climatological Survey, 2019, Daily time series using cooperative observer (COOP) data: Oklahoma Climatological Survey database, accessed November 2019 at http://climate.ok.gov/cgi-bin/public/ climate.timeseries.one.cgi.

Oklahoma Mesonet, 2019, Daily data retrieval, accessed November 25, 2019, at http://www.mesonet.org/index.php/ weather/daily data retrieval.

Oklahoma Water Resources Board [OWRB], 2012a, Oklahoma comprehensive water plan southwest watershed planning region report, $168 \mathrm{p}$. [Also available at https://www.owrb.ok.gov/supply/ocwp/pdf_ocwp/ WaterPlanUpdate/regionalreports/OCWP_Southwest_ Region_Report.pdf.]

Oklahoma Water Resources Board [OWRB], 2012b, Oklahoma comprehensive water plan executive report, 159 p. [Also available at https://www.owrb.ok.gov/supply/ ocwp/pdf_ocwp/WaterPlanUpdate/draftreports/OCWP $\% 20$ Executive\%20Rpt\%20FINAL.pdf.]

Oklahoma Water Resources Board [OWRB], 2015, 2015 Oklahoma groundwater report-Beneficial Use Monitoring Program, 170 p., accessed July 5, 2017, at https://www.owrb.ok.gov/quality/monitoring/bump/pdf_ bump/Reports/GMAPreport2015.pdf.

Oklahoma Water Resources Board [OWRB], 2019a, Interactive maps \& GIS data: Oklahoma Water Resources Board online database, accessed November 2019 at https://www.owrb.ok.gov/maps/index.php.

Oklahoma Water Resources Board [OWRB], 2019b, OWRB open data-Groundwater, accessed November 2019 at https://home-owrb.opendata.arcgis.com/search?tags= groundwater.

Oklahoma Water Resources Board [OWRB], 2019c, OWRB open data - OCWP, accessed November 2019 at https://home-owrb.opendata.arcgis.com/search? tags $=$ OCWP.

Oklahoma Water Resources Board [OWRB], 2019d, OWRB open data - Water rights, accessed November 2019 at https://home-owrb.opendata.arcgis.com/search?tags=rights .

Oklahoma Water Resources Board [OWRB], 2020a, Lakes of Oklahoma, accessed November 2019 at https://www.owrb.ok.gov/news/publications/lok/lok.php.

Oklahoma Water Resources Board [OWRB], 2020b, Maximum annual yield: Oklahoma Water Resources Board Fact Sheet, 2 p., accessed June 5, 2020, at https://www.owrb.ok.gov/about/about_pdf/Fact-MAY.pdf. 
Rantz, S.E., and others, 1982, Measurement and computation of streamflow-Volume 1. Measurement of stage and discharge: U.S. Geological Survey Water-Supply Paper 2175, 284 p., accessed June 5, 2020, at https://doi.org/ 10.3133/wsp2175.

Ries, K.G., III, Newson, J.K., Smith, M.J., Guthrie, J.D., Steeves, P.A., Haluska, T.L., Kolb, K.R., Thompson, R.F., Santoro, R.D., and Vraga, H.W., 2017, StreamStats, version 4: U.S. Geological Survey Fact Sheet 2017-3046, 4 p., accessed June 5, 2020, at https://doi.org/10.3133/ fs20173046.

Roark, D.M., and Healy, D.F., 1998, Quantification of deep percolation from two flood-irrigated alfalfa fields, Roswell Basin, New Mexico: U.S. Geological Survey WaterResources Investigations Report 98-4096, 57 p., accessed June 5, 2020, at https://doi.org/10.3133/wri984096.

Rorabaugh, M.I., 1964, Estimating changes in bank storage and groundwater contribution to streamflow: International Association of Scientific Hydrology, publication 63, p. 432-441.

Runkle, D.L., Bergman, D.L., and Fabian, R.S., 1997, Hydrogeologic data for the Blaine aquifer and associated units in southwestern Oklahoma and northwestern Texas: U.S. Geological Survey Open-File Report 97-50, 213 p., accessed June 5, 2020, at https://doi.org/10.3133/ofr9750.

Runkle, D.L., and McLean, J.S., 1995, Steady-state simulation of ground-water flow in the Blaine aquifer, southwestern Oklahoma and northwestern Texas: U.S. Geological Survey Open-File Report 94-387, 92 p., 1 diskette, accessed June 5, 2020, at https://doi.org/10.3133/ofr94387.

Rutledge, A.T., 1998, Computer programs for describing the recession of ground-water discharge and for estimating mean groundwater recharge and discharge from streamflow records-Update: U.S. Geological Survey Water-Resources Investigations Report 98-4148, 43 p., accessed June 5, 2020, at https://doi.org/10.3133/wri984148.

Ryter, D.W., and Correll, J.S., 2016, Hydrogeological framework, numerical simulation of groundwater flow, and effects of projected water use and drought for the Beaver-North Canadian River alluvial aquifer, northwestern Oklahoma (ver.1.1, February 2016): U.S. Geological Survey Scientific Investigations Report 2015-5183, 63 p., accessed June 5, 2020, at https://doi.org/10.3133/sir20155183.

Schoff, S.L., 1948, Ground-water irrigation in the Duke area, Jackson and Greer Counties, Oklahoma: Oklahoma Geological Survey Mineral Report 18, 8 p.
Scholl, M., Christenson, S., Cozzarelli, I., Ferree, D., and Jaeschke, J., 2005, Recharge processes in an alluvial aquifer riparian zone, Norman Landfill, Norman, Oklahoma, 1998-2000: U.S. Geological Survey Scientific Investigations Report 2004-5238, 54 p., accessed July 5, 2020, at https://doi.org/10.3133/sir20045238.

Sen, P.K., 1968, Estimates of the regression coefficient based on Kendall's tau: Journal of the American Statistical Association, v. 63, no. 324, p. 1379-1389. [Also available at https://doi.org/10.1080/01621459.1968.10480934.]

Shepherd, R.G., 1989, Correlations of permeability and grain-size: Ground Water, v. 27, no. 5, p. 633-638, accessed November 2017 at https://doi.org/10.1111/j.17456584.1989.tb00476.x.

Shivers, M.J., and Andrews, W.J., 2013, Hydrologic drought of water year 2011 compared to four major drought periods of the 20th century in Oklahoma: U.S. Geological Survey Scientific Investigations Report 2013-5018, 52 p., accessed July 5, 2020, at https://doi.org/10.3133/sir20135018.

Smith, J.T., 1970, Ground-water resources of Collingsworth County, Texas: Texas Water Development Board Report $119,115 \mathrm{p}$.

Smith, S.J., Ellis, J.H., Wagner, D.L., and Peterson, S.M., 2017a, Hydrogeology and simulated groundwater flow and availability in the North Fork Red River aquifer, southwest Oklahoma, 1980-2013: U.S. Geological Survey Scientific Investigations Report 2017-5098, 107 p., accessed July 5, 2020, at https://doi.org/10.3133/sir20175098.

Smith, S.J., Ellis, J.H., Wagner, D.L., and Peterson, S.M., 2017b, MODFLOW-NWT model used in simulation of groundwater flow and availability in the North Fork Red River aquifer, southwest Oklahoma, 1980-2013: U.S. Geological Survey data release, accessed July 5, 2020, at https://doi.org/10.5066/F7JQ0ZXH.

Smith, S.J., Ellis, J.H., Paizis, N.C., Becker, C.J., Wagner, D.L., Correll, J.S., and Hernandez, R.J., 2021, MODFLOWNWT model used in simulation of groundwater availability in the Salt Fork Red River aquifer, southwestern Oklahoma, 1980-2015: U.S. Geological Survey data release, https://doi.org/10.5066/P927IAO1.

Smith, S.J., and Esralew, R.A., 2010, StreamStats in Oklahoma-Drainage-basin characteristics and peak-flow frequency statistics for ungaged streams: U.S. Geological Survey Scientific Investigations Report 2009-5255, 59 p., accessed June 5, 2020, at https://doi.org/10.3133/ sir20095255. 
Stanley, T.M., 2004, Geologic map of the Oklahoma part of the Vernon 30' X 60' quadrangle, Jackson and Tillman Counties, Oklahoma: Oklahoma Geological Survey Geologic Quadrangle Map OGQ-60, scale 1:100,000, accessed December 4, 2015, at http://ogs.ou.edu/docs/OGQ/ OGQ-60-color.pdf.

Stanley, T.M., and Miller, G.W., 2004, Geologic map of the Oklahoma part of the Altus 30' X 60' quadrangle, Greer, Harmon, Jackson, and Tillman Counties, Oklahoma: Oklahoma Geological Survey Geologic Quadrangle Map OGQ-59, scale 1:100,000, accessed December 4, 2015, at http://ogs.ou.edu/docs/OGQ/OGQ-59-color.pdf.

Steele, C.E., and Barclay, J.E., 1965, Ground-water resources of Harmon County and adjacent parts of Greer and Jackson Counties, Oklahoma: Oklahoma Water Resources Board Bulletin 29, 96 p.

Stoeser, D.B., Shock, N., Green, G.N., Dumonceaux, G.M., and Heran, W.D., 2005, Geologic map database of Texas: U.S. Geological Survey Data Series 170, accessed February 19, 2020, at https://pubs.usgs.gov/ds/2005/170/.

Stiff, H.A., Jr., 1951, The interpretation of chemical water analysis by means of patterns: Journal of Petroleum Technology, v. 3, no. 10. [Also available at https://doi.org/ 10.2118/951376-G.]

Texas Water Development Board, 2015, Groundwater data viewer: Texas Water Development Board online database, accessed December 4, 2015, at https://www2.twdb.texas.gov/apps/waterdatainteractive/ groundwaterdataviewer.

Texas Water Development Board, 2019, GIS data: Texas Water Development Board web page, accessed September 14, 2019, at http://www.twdb.texas.gov/mapping/gisdata.asp.

Thornthwaite, C.W., and Mather, J.R., 1957, Instructions and tables for computing potential evapotranspiration and the water balance - Centerton, N.J., Laboratory of Climatology: Publications in Climatology, v. 10, no. 3, p. 185-311.

Tortorelli, R.L., 2008, Hydrologic drought of water year 2006 compared with four major drought periods of the 20th century in Oklahoma: U.S. Geological Survey Scientific Investigations Report 2008-5199, 46 p., accessed June 5, 2020, at https://doi.org/10.3133/sir20085199.

Tromino, 2012, Tromino portable ultra-light acquisition system for seismic noise and vibrations-User's manual: Treviso, Italy, Micromed, $139 \mathrm{p}$.

Tromino, 2017, Tromino Grilla software introduction, accessed December 12, 2017, at http://www.tromino.it/softdatabase.htm.
U.S. Census Bureau, 2000, TIGER/line shapefiles and TIGER/ line files: U.S. Census Bureau online database, accessed December 15, 2014, at https://www.census.gov/geo/mapsdata/data/tiger-line.html.

U.S. Census Bureau, 2014, American FactFinder, accessed December 15, 2014, at https://factfinder.census.gov/faces/ nav/jsf/pages/community_facts.xhtml?src=bkmk.

U.S. Environmental Protection Agency [EPA], 2017, Drinking water regulations and contaminants, accessed March 24, 2017, at https://www.epa.gov/dwregdev/drinking-waterregulations-and-contaminants.

U.S. Fish and Wildlife Service, 2015, National Wetlands Inventory-Download seamless wetlands data by State, accessed January 5, 2016, at https://www.fws.gov/wetlands/ Data/State-Downloads.html.

U.S. Geological Survey [USGS], 2015, The National Map-National Elevation Dataset: U.S. Geological Survey National Geospatial Program web site, accessed January 2015 at https://ned.usgs.gov/index.html.

U.S. Geological Survey [USGS], 2019, U.S. Geological Survey surface water and groundwater data for Oklahoma: U.S. Geological Survey National Water Information System (NWIS) database, accessed November 2019 at https://doi.org/10.5066/F7P55KJN or https://waterdata.usgs.gov/ok/nwis/.

Wahl, K.L., and Wahl, T.L., 1995, Determining the flow of Comal Springs at New Braunfels, Texas, in Proceedings of Texas Water '95, a component conference of the First International Conference on Water Resources Engineering, San Antonio, Texas, August 16-17, 1995: American Society of Civil Engineers, p. 77-86.

Westenbroek, S.M., Kelson, V.A., Dripps, W.R., Hunt, R.J., and Bradbury, K.R., 2010, SWB-A modified Thornthwaite-Mather Soil-Water-Balance code for estimating groundwater recharge: U.S. Geological Survey Techniques and Methods 6-A31, 60 p., accessed June 5, 2020, at https://doi.org/10.3133/tm6A31.

White, J.T., 2018, A model-independent iterative ensemble smoother for efficient history-matching and uncertainty quantification in very high dimensions: Environmental Modelling \& Software, v. 109, p. 191-201, accessed June 5, 2020, at https://doi.org/10.1016/j.envsoft.2018.06.009.

White, W.N., 1932, A method of estimating ground-water supplies based on discharge by plants and evaporation from soil-Results of investigations in Escalante Valley, Utah: U.S. Geological Survey Water-Supply Paper 659-A, 105 p., accessed June 5, 2020, at https://doi.org/10.3133/wsp659A. 
Willis, G.W., and Knowles, D.B., 1953, Ground-water resources of the Odell sand hills, Wilbarger County, Texas: Texas Board of Water Engineers Bulletin 5301, 54 p.

Winston, R.B., comp., 2018, Online guide to MODFLOWNWT-Suggested input values for the NWT input file, accessed November 2018 at https://water.usgs.gov/ogw/ modflow-nwt/MODFLOW-NWT-Guide/index.html? suggested_input_values_for_the.htm.
World Climate Research Programme, 2020, Coupled Model Intercomparison Project 5 (CMIP5), accessed June 5, 2020, at https://esgf-node.llnl.gov/projects/cmip5/.

X-Rite, Inc., 2009, Munsell soil color book: Grand Rapids, Mich. [Also available at https://munsell.com/color-products/ color-communications-products/environmental-colorcommunication/munsell-soil-color-charts/.] 

For more information about this publication, contact Director, Oklahoma-Texas Water Science Center U.S. Geological Survey

1505 Ferguson Lane

Austin, Texas 78754-4501

For additional information, visit https://www.usgs.gov/centers/ot-water/

Publishing support provided by Lafayette Publishing Service Center 


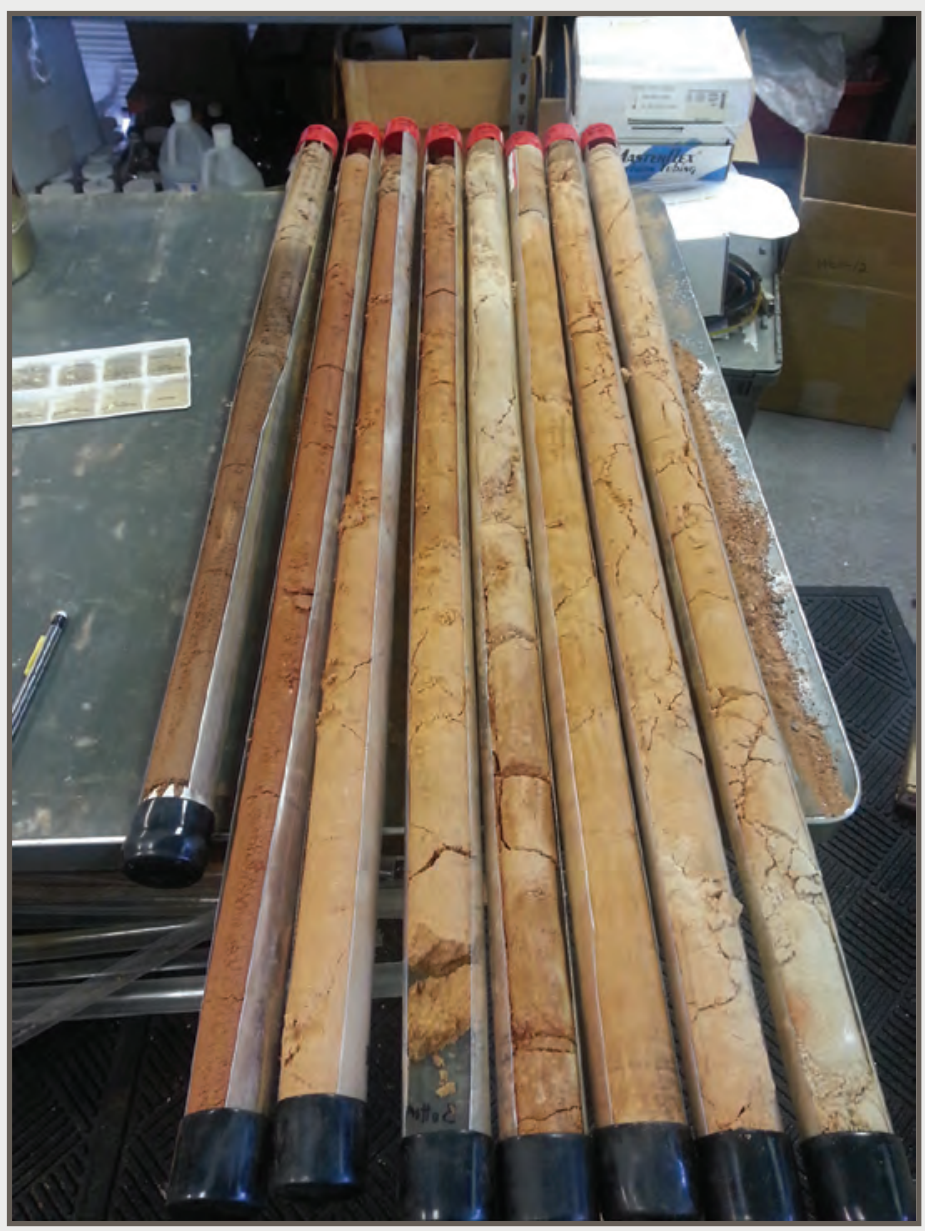

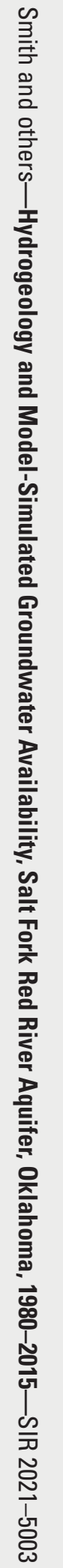

